The Contributions of George G. Higgins

to the Social Action Movement in the United States, $1944-1980$

\author{
Daniel R. Conkle \\ Pensacola, FL
}

M.A., University of Virginia, 2013

M.A., Catholic University of America, 2001

B.A., University of the South, 1997

\begin{abstract}
A Dissertation presented to the Graduate Faculty
of the University of Virginia in Candidacy for the Degree of

Doctor of Philosophy
\end{abstract}

Department of Religious Studies

University of Virginia

December, 2013 


\begin{abstract}
George G. Higgins joined the Social Action Department (SAD) of the National Catholic Welfare Conference in the spring of 1944, an organization which sought to implement the social teachings of the Catholic Church within American society. Higgins served the American Catholic hierarchy in this regard for over 36 years, acting on their behalf as the Assistant Director of the SAD from 1946 to 1954 , as a director of the department from 1954 to 1972 , and finally as a consultant to the United States Catholic Conference from 1972 to 1980. As a member of the department, Higgins followed the agenda of his director, Fr. Raymond A. McGowan, who sought to implement the Industry Council Plan of Pope Pius XI's 1937 encyclical, Quadragesimo Anno. It was an effort that Higgins would consistently promote throughout his years of service to the American Catholic Church, and one which influenced the development and understanding of Catholic social action both prior to and following the Second Vatican Council of the 1960s.
\end{abstract}

The historical account of Higgins's actions during these 36 years of service details the efforts of the American Catholic Church to influence the social order of the United States, as well as the development of its understanding of social action from the 1940s to the 1980s. In particular, Higgins's efforts to validate lay participation within secular organizations contributed to a new understanding of its place within the American Catholic Church, and empowered lay Catholics to act outside of approved organizations that were directed by the hierarchy. In doing so, Higgins helped prepare American Catholics for the reforms promoted by the Second Vatican Council, including its call for the laity to take on a greater role within the Church. Finally, the account sheds further light on the American Catholic Church's relationship with labor for this 
period, as these were the primary secular organizations that Higgins promoted as an acceptable expression of Catholic social action. Consequently, George Higgins stands as one of the principal Catholic social reformers of the $20^{\text {th }}$ century. 


\section{Table of Contents}

Preface

Key to Abbreviations

1. Introduction

2. McGowan as Director:

Higgins's Introduction to the Social Action Department

3. Implementation of Quadragesimo Anno:

The SAD's Response to the Taft-Hartley Act

4. Higgins's Introduction to the Directorship:

The Crisis of the McClellan Committee and Its Implications

for the Labor Movement

5. A Return to Taft-Hartley:

Higgins's Introduction of the Liturgical Movement to Motivate

the Rank-And-File

6. The Unified Apostolate for the Universal Church:

The Impact of the Encyclicals of Pope John XXIII and their

Culmination at the Second Vatican Council

7. The Start of Dialogue: The Creation of the American

Secretariat for Catholic-Jewish Relations

8. A Return to Labor Conflict: The United Farm Workers'

Movement and the Bishops' Ad Hoc Committee on

Farm Labor

9. The Retirement Scandal: The United States Catholic

Conference of Bishops' Decision to Retire Higgins

Epilogue

Bibliography 


\section{Preface}

The study of American Catholic social action has largely focused on the contributions of Msgr. John A. Ryan, the first director of the National Catholic Welfare Conference's Social Action Department (SAD). This emphasis is understandable, given Ryan's contributions to Catholic social theory, which were numerous and ground-breaking for his day. Among these contributions stood his promotion of the living wage espoused in Pope Leo XIII's Rerum Novarum, and his development of the Bishops' Program of Social Reconstruction of 1919. In particular, the Bishops' Program of Social Reconstruction advocated much of the legislation implemented by President Franklin D. Roosevelt's New Deal of the 1930s. This fact, along with Ryan's vocal support of the President, earned him the moniker, "Right Reverend New Dealer."

Yet, surprisingly little has been written about Ryan's successors within the Social Action Department, and their contribution to Catholic social action in the years following Ryan's passing. This is certainly the case of Ryan's assistant director, Raymond A. McGowan, who assumed the directorship from 1945 to 1954 . This dearth of scholarship is likely due to the scarcity of archival documentation left by McGowan, of which the files of the Catholic Conference on Industrial Problems constitute the bulk of material available. ${ }^{1}$ However, this is not the case with McGowan's successor, George G. Higgins, who served as the director of the department from 1954 until 1972, and of which there is an abundance of archival material.

Unfortunately, it seems that many historians have simply assumed that McGowan's and Higgins's contributions to American Catholic social action merely continued the policies of John

\footnotetext{
${ }^{1}$ Thomas Greene's article, "The Catholic Conference on Industrial Problems in Normalcy and Depression," provides a detailed analysis of the Conference, and McGowan's contributions to its management and agenda. (Thomas Greene, "The Catholic Conference on Industrial Problems in Normalcy and Depression," Catholic Historical Review 77 (July 1991), 437 - 469)
} 
A. Ryan. In the case of Higgins, this is simply not true. First and foremost, while Ryan relied almost entirely on legislation and the power of the state to transform society, Higgins proposed a collaboration of government and voluntary associations to guide such a transformation. This was due in large part to both McGowan's and Higgins's understanding and promotion of the Industry Council Plan espoused by Quadragesimo Anno, the 1931 social encyclical of Pope Pius XI. Their interpretation of this plan relied heavily on the contributions of voluntary associations, especially the unions of the American labor movement, which in turn required a more comprehensive development of a lay social apostolate within the United States. Once Higgins became director the Social Action Department, he differentiated himself from his predecessor, McGowan, by applying the precepts of Virgil Michel's liturgical movement to the lay social apostolate. This was a movement which, according to Ryan's biographer, Francis L. Broderick, Ryan was largely unaware, and which differentiates Higgins from the first director of the SAD.

What scholarship there is on Higgins has been limited in its scope and form as far as the historical record warrants. First and foremost stands Gerald Costello's Without Fear or Favor: George Higgins on the Record. This biography documents the life of Higgins through interviews and non-documented correspondence, and details his contributions to such fields as the labor movement, the farm labor movement, the Second Vatican Council, interracial justice and his time at the Social Action Department of the National Catholic Welfare Conference. However, the work itself was written from a journalist's perspective, as opposed to the historian's. As Costello attests by e-mail, his background was "in journalism and not in academics," and as a consequence he "approached [his] book on George as a reporter rather than as a historian."2 Consequently, the work itself, while detailing some of the actions and explaining some of the

\footnotetext{
${ }^{2}$ Gerald Costello, e-mail message to author, February 10, 2009
} 
personal views of Higgins, does not place those contributions within a historical context.

Furthermore, the documents used by Costello in this work were included without citation or reference, and as a result there is no historical record of evidence for the biography. Fortunately, the transcripts of the interviews conducted by Costello are housed within the archives of the Catholic University of America, as well as the majority of Higgins's correspondence, some of which was undoubtedly used in the creation of Costello's work. ${ }^{3}$ However, given the presentation and form of the work itself, it seems better to consider Without Fear or Favor as primary source material. ${ }^{4}$

In conjunction with Costello's Without Fear or Favor stands Organized Labor and the Church: Reflections of a Labor Priest, a book written by Higgins along with William Bole. The work itself opens with an autobiographical account of Higgins's formative years, and then explores the relationship that the American Catholic Church has had with labor from the time of Cardinal James Gibbons to the late 1980s. Along with his historical assessment of this relationship, Higgins also provides his views on the current state of those relations at the time of publication, and the direction he hoped Catholic social action might take in the future. Given the focus and direction of this work, it too warrants treatment as primary source material, along the same lines as Without Fear or Favor.

The only other work of note is John J. O'Brien's George Higgins and the Quest for Worker Justice. O'Brien charts the development of Higgins's social theology throughout his life by focusing on the editorials found in The Yardstick, Higgins's column for over fifty-five years.

\footnotetext{
${ }^{3}$ As has been noted, while the Catholic University Archives hold the majority of documents, including those used in Without Fear or Favor, Costello still retains possession of some documents given by Higgins to Costello during the writing of the biography.

${ }^{4}$ Even more so, the transcripts of the interviews of Without Fear or Favor are especially relevant as primary source material.
} 
Besides this, O'Brien also uses the Labor Day Statements written by Higgins during the same time period. By focusing on these two aspects of Higgins's professional life, O'Brien argues that Higgins's social theology rested upon "four interlocking ideas: the dignity of the human person, the common good, the desire to build community, and participation in decision making." Ultimately, he argues that "the goal of Higgins' social teaching was to restore all things in Christ and to create a just, happy, and wholesome social order." According to O'Brien, this social theology was built on "a traditional theological anthropology of sin and grace and on a classical, albeit Biblically rooted ecclesiology. The human person must freely choose either to build community, encourage participation, and create structures of cooperation or turn the other way, retreat into self-serving individualism, and cultivate greed and self-interest.... For Christians, the redemptive community is the Church. Higgins' ecclesiology, rooted in the Pauline metaphor of the body of Christ, is the mystical body. Each part of that body has a role to play and a function to perform for the good of the whole... Higgins kept liturgy and social action together."6

O’Brien's work, while beneficial in understanding the theological underpinnings and basis of Higgins's social work, does not place the development of Higgins's theology within a historical context. The events and individuals who undoubtedly influenced Higgins are not taken into account, nor does O'Brien provide adequate detail as to how Higgins' theological views influenced his actions in the secular world. This is especially true of Higgins's liturgical development, to which O'Brien refers, but provides little in the way of detailed examination. This is in part due to O'Brien's reliance upon the Labor Day Statements and published columns of The Yardstick. Virtually no correspondence is cited within O'Brien's George G. Higgins and the Quest for Worker Justice, and the bulk of Higgins's addresses and sermons outside of the

\footnotetext{
${ }_{6}^{5}$ O’Brien, George G. Higgins, 204

${ }^{6}$ Ibid., 204-205
} 
Labor Day Statements remain untouched. Furthermore, the historical events surrounding Higgins's time as a labor mediator for the Church are only briefly addressed. As a result, O'Brien's work serves much more as a summarization of Higgins's social theology, and not as a historical treatise.

Other works relevant to Higgins may be considered cursory at best. Among them is Marco G. Prouty's César Chávez, the Catholic Bishops, and the Farmworkers' Struggle for Social Justice. Prouty's book covers the role of the American Church, specifically the Bishops' Ad Hoc Committee on Farm Labor, which served as a bridge between ownership and labor, and was created to "determine whether or not there was anything that could be done to mediate ... [César Chávez's grape] dispute in California."7 Perhaps more importantly, the USCC/NCCB president, Cardinal John Francis Dearden, the Archbishop of Detroit, had granted the same committee the right to make statements in the name of the entire American Catholic hierarchy on the dispute if necessary. Higgins served as a consultant to the committee, and so played an important role as an intermediary between Chavez's La Causa farm labor movement and the vineyard owners. However, the focus of Prouty's work is that of the American hierarchy and the Ad Hoc Committee, its relationship with La Causa, and its role in settling both the grape dispute and the "Salad Bowl" conflicts of California from the 1960s and 1970s. Consequently, while Higgins is placed within this scope, his involvement is not a focal point of that history.

Besides Prouty's work, two theses address Higgins indirectly as well. One is Sylvia M. Batdorf's Master's thesis, “The Work of the Social Action Department of the National Catholic Welfare Conference in All Phases of Industrial Relations”. Its complement, another Master's

\footnotetext{
${ }^{7}$ Marco G. Prouty, César Chávez, the Catholic Bishops, and the Farmworkers' Struggle for Social Justice, (University of Arizona Press,2006), 55
} 
thesis titled "The Work in Industrial Relations of the Social Action Department of the National Catholic Welfare Conference, 1933 - 1945" was written by Rev. William James Lee. Both of these theses are worth mentioning if only that they serve to provide necessary historical information concerning the agency where Higgins worked the majority of his years. However, in the same breath it should be noted that the works themselves focus mainly on the years prior to Higgins's arrival at the SAD of the NCWC.

Besides these two theses, there are other historical contributions that address the work of the SAD, as well as that of the NCWC itself. Among these stands Thomas R. Greene's "The Catholic Conference on Industrial Problems in Normalcy and Depression" which appeared in the Catholic Historical Review. His article directly addresses McGowan's Conference and its influence of American Catholic Social Action, of which Higgins assisted as Assistant Director. Greene's article on the Conference, which includes the history of McGowan's role in its creation and implementation, provides an otherwise overlooked view of the inner workings of the department. There are articles covering the NCWC itself, such as Elizabeth McKeown's “The National Bishops' Conference: An Analysis of Its Origins", which appeared in the Catholic Historical Review, as well as her treatment of the Conference in Episcopal Conferences: Historical, Canonical, and Theological Studies. ${ }^{8}$ Besides her contributions, Douglas J. Slawson's The Foundation and First Decade of the National Catholic Welfare Council also outlines the origin, development, and focus of the NCWC in its first decade of operation. Again, much like the works mentioned previously, these works address Higgins indirectly, in that they provide necessary and valuable background history to Higgins's work at the SAD of the NCWC. At the

\footnotetext{
${ }^{8}$ Gerald P. Fogarty also treats the canonical basis of the NCWC in the same work.
} 
same time, they do not directly address his work at the agency, nor do they assess the impact and contribution of the department during Higgins' tenure there.

This dissertation hopes to remedy, at least in part, the lack of scholarship concerning Higgins, the NCWC, and the SAD. Given that these organizations served at the forefront of American Catholic social thought and action, of which George Higgins played no small part, a historical treatment of Higgins and his role within the department would fill a gap in the history of the American Catholic Church and its relation to the labor industry in the United States. Insofar as the structure of this work, the introduction is meant to serve as a general overview of Higgins's life, his influences, and his contributions to Catholic social action during his years at the SAD. The following chapters detail his contributions to the social action movement, starting with his apprenticeship as the Assistant Director of the Department, and ending with his retirement from the United States Catholic Conference in 1980. Intermediary chapters focus on Higgins's implementation of the Industry Council Plan; his participation in the United Auto Workers' Public Review Board during the investigation of the U.S. Senate's McClellan Committee hearings; his attempt to influence the lay social apostolate and American unions through his application of Virgil Michel's liturgical movement; the influence of the encyclicals Mater et Magistra and Pacem in Terris, as well as experience as a peritus at the Second Vatican Council, upon his understanding of the lay apostolate's role within the United States; his work setting up and serving as a member of the Secretariat for Catholic-Jewish Relations following the Council; and his involvement in the Bishops' Ad Hoc Committee on Farm Labor in the first half of the 1970s. 


\section{Acknowledgements}

This work would not have been possible without the patience, support, and guidance of many. As a testimony to this fact, I thank my advisor and mentor, Father Gerald P. Fogarty, whose counsel, support, and encouragement were essential for the completion of this work. The same may be expressed in regard to my family - none of this would have been possible without the support of my parents, Dr. David M. Conkle and Barbara L. Conkle, and my loving wife, Brooke. To all of you, I express my undying gratitude for what you have enabled me to accomplish, and I suspect, will continue to do so far in the future.

I also wish to extend special thanks to the staff of the American Catholic History Research Center and University Archives, especially that of John Shepherd and Paul Kelly. As my numerous copies attest, their service was an essential part of my task. In the same breath, I also thank Jake Currie and Susanna Hsing, whose generosity and hospitality allowed me to pursue my research. Without their aid, this dissertation would not have been possible.

Finally, I thank all my coworkers and friends in Charlottesville, who have had the pleasure of listening to my ramblings over these past few years. I thank you for lending your ear, for your input, and for your continued support and encouragement. It will not be forgotten. 


\begin{abstract}
Abbreviations of Archives
Archives of the Catholic University of America:

ACUA

Papers of the United States Conference of Catholic Bishops Social Action Department:

USCCB SAD Papers

Papers of the United States Conference of Catholic Bishops

Office of the General Secretary:

USCCB OGS Papers

George Gilmary Higgins Papers:

GGH Papers

Archives of the University of Notre Dame:

UNDA

Association of Chicago Priest Records:

ACP Papers

Catholic Committee on Urban Ministry Records:

CCUM Papers
\end{abstract}

\title{
Abbreviations of Organizations
}

American Federation of Labor:

AFL

American Federation of Labor and Congress of Industrial Organizations:

AFL-CIO

California Labor Relations Act:

CALRA

California Labor Relations Board:

CALRB

Catholic Association for International Peace:

CAIP

Catholic Conference on Industrial Problems:

CCIP

Congress of Industrial Organizations:

$\mathrm{CIO}$

Committee on Research, Plans, and Programs:

CRPP

Inter-American Catholic Social Action Confederation:

IACSAC

Int'l Union, United Automobile, Aerospace and Agricultural Implement Workers: UAW

National Catholic Conference of Bishops:

NCCB

National Catholic Welfare Conference:

NCWC

National Farm Workers Association:

NFWA

National Industrial Relations Act:

NIRA

National Labor Relations Act:

NLRA

National Labor Relations Board:

NLRB

National Recovery Administration:

NRA

Social Action Department:

SAD

United Auto Workers' Public Review Board:

PRB

United Farm Workers of America, AFL-CIO:

UFW

United Farm Workers Organizing Committee:

UFWOC

United States Catholic Conference:

USCC

United States Catholic Conference of Bishops:

USCCB 


\section{Chapter 1}

\section{Introduction}

The Second Vatican Council "did not generate the phenomenon of rapid change in the Church but merely coincided with it, validated it, gave it a certain impetus and, even more importantly, a certain theological and pastoral respectability. Rapid change would have come into the Church with or without a council, but with this all important difference: In the absence of a council, it probably would have come largely in protest against the real or alleged inadequacies of Catholic thought and pastoral practice and not in response to an orderly study of theological and biblical sources and a systematic reappraisal of the Church's needs and opportunities. The council, in other words, was the providential safety valve that made it possible - or so it seems to many observers - to forestall a disastrous explosion in the life of the Church."

- $\quad$ Rev. George G. Higgins, The Yardstick, Dec. 29, 1968

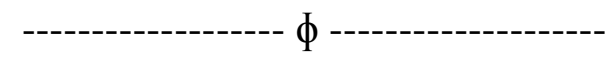

Such was the assessment of George Higgins in November of 1970, some five years after his service as a peritus, or theological expert, at the Council. Up to this time he had been many things in his career of service to the American Catholic Church: columnist for The Yardstick, a regular bi-monthly Catholic column that compared social reforms of the day in light of the encyclicals; chairman of the Public Review Board for the United Auto Workers, which served as an appeals court for the union; consultant to the Bishops' Ad Hoc Committee on Farm Labor, which mediated the conflict between the United Farm Workers of America and the growers of California; founding member of the Secretariat for Catholic/Jewish Relations; and as the Assistant Director, and later the Director, of the Social Action Department (SAD) of the National Catholic Welfare Conference (NCWC). It was as a peritus at the Council, however, that he employed his extensive experience as a negotiator, spokesman, and theologian, but instead of 
acting as the intermediary between labor and management, he served as the mediator between bishops, and between bishops and other theologians.

Higgins's service at the Second Vatican Council constituted a major contribution to the American Church. American bishops were ill-prepared for the demands and rigors of the Council - for even though the bishops came together through the auspices of the NCWC, there was little collegiality among them. As Gerald Fogarty had pointed out, the "American Church was still a Church of doers rather than thinkers. For the 226 bishops who went to Rome, the council would be a learning experience." ${ }^{1}$ With his experience in the politics of mediation, Higgins's assistance proved essential to American bishops in such a learning curve.

Born on January 21, 1916 in Chicago, Illinois, George Higgins was the oldest of five children. George's father, Charles Higgins, had worked in the railroads prior to his marriage to Anna Rethinger in 1912, but left this line of work to become a postal clerk, moving his family to LaGrange, Illinois, some seventeen miles from the center of Chicago. George attended St. Francis Xavier's grammar school until the eighth grade, after which he became a seminarian at Quigley Preparatory Seminary, located on Chicago's Near North Side. ${ }^{2}$

Chicago was a city steeped in industry, so much so that it would have undoubtedly influenced Higgins and his development as a young man. Founded near the shores of Lake Michigan, and divided by the Chicago River, the city's waterways promoted cheap access to raw goods, and the markets that came with them. Besides having the advantage of such a natural resource, Chicago's extensive railways and road works connected Chicago to the Western United

\footnotetext{
${ }^{1}$ Gerald P. Fogarty, The Vatican and the American Hierarchy from 1870 to 1965 (Collegeville: Liturgical Press, 1982), 386.

${ }^{2}$ Gerald M. Costello, Without Fear or Favor: George Higgins on the Record (Mystic: Twenty-Third Publications, 1984), 3.
} 
States. This transportation system greatly benefited the city, as the produce of the West traveled through Chicago to the rest of the nation, which contributed to its economic growth and status. ${ }^{3}$ During the years of Higgins's attendance at Quigley Prep, the city hosted a range of workers and industry, but was hard pressed by the economic circumstances of the time. Starting in 1929, the Great Depression forced a period of decline for labor, as collective bargaining suffered losses and concessions to capital. Wage cuts became the norm of collective bargaining, as unions fought to preserve their contracts in the face of growing unemployment. The loss of jobs was such that at one point approximately $50 \%$ of the city's workforce was unemployed, which only benefited management in its collective bargaining with the unions. ${ }^{4}$

In the 1920s seventy percent of the population of Chicago hailed from lands other than the United States. Chicago was an immigrant's city, and it is safe to assume that this large group of people made up the working class. ${ }^{5}$ In the same breath it would also be safe to assume that the majority of this seventy percent were Catholic, as the majority of these immigrants came from both Ireland and Poland. While in Chicago, Higgins would have seen and experienced all of this, being of Irish descent himself, and a Catholic. He would have noticed the skilled and unskilled workers of the railways as he commuted back and forth from LaGrange to Quigley Prep; he would have seen those searching for work, in any of the surrounding industries, whether it be that of clothing manufacture, the meat processing district, or the iron and steel industry of Chicago; he could have turned his radio station to Chicago's "Voice of Labor", the WCFL, the first radio station owned by a labor organization, based in Chicago, founded in 1926. According to Higgins, the "the thrill of walking down Michigan Boulevard... in the midst of throngs of

\footnotetext{
${ }^{3}$ Barbara Warne Newell, Chicago and the Labor Movement: Metropolitan Unionism in the 1930's (Urbana: University of Illinois Press, 1961), 9.

${ }^{4}$ Ibid., 41.

${ }^{5}$ Elizabeth McKillen, Chicago Labor and the Quest for a Democratic Diplomacy, 1914 - 1924 (Ithaca: Cornell University Press, 1995), 4.
} 
commuters and shoppers" was an incredible experience, and if he had "'had gone to school in LaGrange," "he would have missed all of it. ${ }^{6}$

Higgins' time in Chicago came to a close when he enrolled at St. Mary’s Seminary in Mundelein, Illinois in 1934. It was at St. Mary's that Higgins studied under the direction of liturgical reformer Msgr. Reynold Hillenbrand, who served as the rector of St. Mary's at that time, and where he also garnered the attention of Archbishop Samuel Stritch, who succeeded Cardinal George Mundelein of Chicago in 1939. As rector, Hillenbrand incorporated courses on Catholic social teaching into the curriculum, as well as summer seminars on modern social encyclicals, where such Catholic notables as John A. Ryan, Francis Haas, and Raymond McGowan all lectured on the social question. The training was fortuitous, since Higgins would later work under both Ryan and McGowan in their roles as the Directors of the SAD. From Higgins' point of view, Hillenbrand basically “ushered in an ecclesiastical New Deal at Mundelein" through the courses and practices he instituted, among which was a focus on the liturgical aspect of social justice. ${ }^{7}$

After having been ordained in 1940, Hillenbrand recommended that Higgins pursue a doctorate in economics at the Catholic University of America in Washington, D.C. Archbishop Stritch concurred. ${ }^{8}$ Higgins's dissertation, "Voluntarism in Organized Labor in the U.S., 1930 1940," focused on the policy of voluntarism as understood by the American Federation of Labor

\footnotetext{
${ }^{6}$ Costello, Without Fear or Favor, 5.

${ }^{7}$ Msgr. George G. Higgins with William Bole, Organized Labor and the Church: Reflections of a Labor Priest (Mahwah: Paulist Press, 1993), 19.

${ }^{8}$ Reynold Hillenbrand served as rector of St. Mary's Seminary, where as an avid follower of Virgil Michel, he emphasized a greater understanding of the liturgy, but centered on reformist views. Among these were a greater emphasis on the doctrine of divine life and the theology of the Mystical Body, "because without understanding these it is quite useless to talk about the details of the Mass and the historical elements that enter into the Mass." Citation and greater detail of Hillenbrand's life and influence from Robert Tuzik, "The Contribution of Msgr. Reynold Hillenbrand (1905 - 1979) to the liturgical movement in the United States: Influences and Development" (PhD diss., Notre Dame University, 1989), 42.
} 
[AFL], and to a lesser degree that of the Congress of Industrial Organizations [CIO].

Voluntarism, as Higgins described it, is a form of "group individualism" found within the labor movement which resisted government aid and influence (and any legislation that may result in such) under the belief that their own economic strength could provide the movement with better gains, and that government legislation only served to impose limits and restrictions on issues that were essential to labor's cause. From the viewpoint of the AFL, dependence upon "legislation of this kind would tend to weaken the loyalty of the workers to their union," relying too much upon government - which had proved to be inconsistent to the cause of labor - than upon their own economic strength to bring about change. Consequently, for the period of the 1920s to the 1930s, the AFL was "unwilling to allow any limits to be set to the aspirations of Labor", and "feared that governmental regulation in the field of wages and hours would tend to establish limits" upon Labor's gains. ${ }^{9}$ This viewpoint of Labor lasted until the end of the 1930s, as the weight of the depression changed labor's views on legislation, government aid, and its place within the movement.

Higgins completed his degree in economics from the Catholic University of America in 1944. He planned to return to Mundelein Seminary as a teacher, but fate intervened. Father John Hayes of the Social Action Department contracted tuberculosis, and at the request of Father Raymond McGowan, the full-time assistant director of the agency, Archbishop Stritch assigned Higgins "temporarily" to replace him. Strangely, Archbishop Stritch "never made a formal decision" on Higgins's appointment to the NCWC, "simply allowing the move to take place without commenting on it (or without assigning Higgins anywhere else)." ${ }^{\prime 10}$ What Higgins must

\footnotetext{
${ }^{9}$ George G. Higgins, "Voluntarism in Organized Labor in the U.S., 1930 - 1940" (PhD diss., Catholic University of America, 1944), 36.

${ }^{10}$ Costello, Without Fear or Favor, 11.
} 
have assumed was a temporary assignment lasted for thirty-six years, until Higgins retired from the organization on September 1, 1980.

The NCWC followed in the steps of the National Catholic War Council, which had formed under the guidance of Father John J. Burke, C.S.P., during the First World War. Burke ran the Chaplain's Aid Association of New York, and served as the editor of the Catholic World prior to his efforts to unify the American Church's war effort. Burke believed that the Catholic war effort required a recognizable authority at its center, as opposed to the various lay groups independently contributing to the war effort. In particular, Burke sought to quell the organizational infighting that was harming the war effort. Many lay organizations accused the Knights of Columbus of overstepping their authority by working in the name of the Church, and by excluding others in the endeavor. Ultimately, Burke was successful in this regard, forming the Council in January of $1918 .^{11}$

From the outset of the War Council, members of the Catholic hierarchy vocalized the need to create a permanent organization that would represent Catholic interests. Among them stood Bishop Joseph Busch of St. Cloud, Minnesota, who expressed to Cardinal James Gibbons, the Archbishop of Baltimore, "that the National Catholic Council be ... not merely limited to time of war", and Bishop Henry Gabriels of Ogdensburg, New York, who hoped the War Council "might serve as a permanent institution for the conduct of various Catholic activities after the war." ${ }^{12}$ And with the close of World War I, and its war effort to support Catholic troops, there

\footnotetext{
${ }^{11}$ Douglas J. Slawson, The Foundation and First Decade of the National Catholic Welfare Council (Washington, D.C.: The Catholic University Press, 1992), 27 - 32.

${ }^{12}$ Joseph Busch to James Gibbons, November 26, 1917, Archives of the Archdiocese of Baltimore, RG 13, Box 7; Joseph Conroy to James Gibbons, November 27, 1917, Archives of the Archdiocese of Baltimore, RG 13, Box 7 , both quoted in Slawson, The Foundation and First Decade of the National Catholic Welfare Council, 31. Slawson has these documents located at the Sulpician Archives in Baltimore, even though they are located at the Archives of the Archdiocese of Baltimore.
} 
was no longer a need for the Catholic War Council, but the Council itself had served another purpose by setting the stage for the creation of the National Catholic Welfare Council.

In February of 1919 seventy-five bishops assembled at Catholic University to celebrate the golden jubilee of Cardinal Gibbons' consecration as a bishop in 1868. Archbishop Bonaventura Cerretti, the secretary of the Congregation of Extraordinary Ecclesiastical Affairs and Pope Benedict XV's personal representative, was in attendance as well. During the course of the celebration, Cerretti expressed both his and the Pope's desire that the American hierarchy would form an organization in unity with the Pope's call for a lasting peace based on Catholic principles of education and social justice. ${ }^{13}$ It was at this meeting that the seeds of the National Catholic Welfare Council were planted. ${ }^{14}$ Gibbons immediately appointed a committee to determine how best to implement such a request, and John J. Burke's plan for a national council carried the day.

The NCWC's original structure was such that seven bishops, serving in an administrative committee that presided over and acted through five departments (Press, Social Action, Legal, Lay Activities and Education), would represent the hierarchy between annual meetings and have the full authority to act on behalf of the bishops as a whole. "Strictly speaking, the Welfare

\footnotetext{
${ }^{13}$ John B. Sheerin, C.S.P., Never Look Back: The Career and Concerns of John J. Burke (New York: Paulist Press, 1975), 58.

${ }^{14}$ Papal approval for the proposed annual meeting of the bishops stemmed from Pope Benedict XV, who had approved two commissions, one for social questions and the other for education, both under the umbrella of the Catholic Committee of Catholic Interests. However, it appears that Benedict had not specifically called for the creation of an annual meeting of the hierarchy as a whole, which led to its temporary suppression, and ultimately its change of name to the National Catholic Welfare Conference. Gibbons and his contemporaries had used the two commissions statement - present in a message to Gibbons in May of 1919 - to argue that Benedict wished the hierarchy " "to form committees to study and work for the welfare of the Church and country, particularly along social and educational lines"', and that the pope approved them doing so in annual meetings (Slawson, The Foundation and First Decade of the National Catholic Welfare Council, 55).

${ }^{15}$ The seven bishops assigned to the run the NCWC were Edward Hanna, archbishop of San Francisco; Dennis Dougherty, archbishop of Philadelphia; Austin Dowling, archbishop of Saint Paul; Regis Canevin, bishop of Pittsburgh; Peter Muldoon, bishop of Rockford; and Joseph Schrembs, bishop of Toledo. Each department was run by one of the bishops: Dougherty led the Legislation Department, Dowling managed Education, Schrembs ran Lay
} 
Council was the hierarchy in annual assembly. By extension, the name also applied to the Administrative Committee and subsidiary departments, which implemented the hierarchy's decisions. The NCWC was, therefore, a complex structure embracing the totality of American bishops operating through an executive branch."16 Unfortunately, the nature of the initial structure of the National Catholic Welfare Council immediately created conflict within the body of bishops. The design of the NCWC, and in particular its title of "council," potentially compromised the singular authority of each bishop within his corresponding diocese, should the bishop ever disagree with the stance of the Council. Consequently, changes were made to the organization. Besides a change in name from "Council" to "Conference," the NCWC was limited in action to carrying out the expressed wishes of the bishops in annual meetings. By the time Higgins joined, the National Catholic Welfare Council had become the National Catholic Welfare Conference - although for all intents and purposes its goals remained very much the same as it had been under its previous name. ${ }^{17}$

As an organization, the NCWC sought to influence both public opinion and the legislative process in directions favorable to Catholics. Given that the NCWC had "no legislative powers, and no means within itself for affecting the action it might urge", the organization - and its various departments - served as a "clearing house for the distribution of the best Catholic study on the social relationships with which it dealt, and thus [was], primarily, educational in

Organizations, and Muldoon led the Social Action Department. Outside of these five, Hanna served as the first episcopal chairman of the NCWC.

${ }^{16}$ Slawson, The Foundation and First Decade of the National Catholic Welfare Council, 68.

${ }^{17}$ Among those changes, attendance of the annual meetings became a matter of choice for individual bishops, and the assembly's meetings were "not to have the force of law." Furthermore, the annual assembly's meetings published its agenda in advance of the meeting, with the presider of the meeting determined by canonical rule of precedence. Finally, the agenda and the resolutions of the annual assembly of the NCWC were sent to Rome for review. The Vatican also suggested the assembly change its name from "council" to "conference", as "council" appeared to give the assembly an authority that was not its due (Ibid., 175-176). 
purpose. ${ }^{, 18}$ As a consequence, the SAD followed very much the same tack, and sought to establish a "civic, social, and economic welfare" through educative services. By doing so it hoped to fulfill Benedict's charge to "deal with the social question," which it understood as the effort to "coordinate those activities which aim at improving social conditions in accordance with the spirit of the Church." 19 These services took the form of the following: its writings, which consisted of a weekly press release and dissemination of pamphlet literature; joint studies with other denominational faiths on social issues of the day; and promoting study groups for the lay members of the church. Besides this the department hosted lectures at colleges, seminaries, and secular universities, all geared towards addressing the problems of child welfare and industrial relations.

The Bishops' Program of Social Reconstruction and Bishops' Pastoral Letter of 1919, as well as the social encyclicals Rerum Novarum (1891) and Quadragesimo Anno (1931), served as the basis of the SAD's social teaching. Concerned with the state of the country following the war, the bishops' addressed the inefficiency and waste of industry, as well as the income gap of wage earners versus a privileged few in society. Addressing such concerns, the bishops advocated that the wage rates of the war be maintained for the benefit of the working class, as these wages had met the standards of a living wage. Besides such recommendations, the program advocated greater representation of the worker in industry, and a legal minimum wage for all workers. ${ }^{20}$ At the same time, the body of bishops' Pastoral Letter of 1919 addressed the unequal

\footnotetext{
18 "Brief Historical Review of the Inception of the Work and Its Aims", ACUA/USCCB SAD Papers, Box 1, Folder 4,6 .

${ }^{19}$ Ibid., 5.

${ }^{20}$ Our Bishops Speak: National Pastorals and Annual Statements of the Hierarchy of the United States (Milwaukee: Bruce Publishing Company, 1952), 248 - 257.
} 
distribution of wealth that America faced. This disparity of wealth and the materialistic focus of society threatened the peace of the social order. ${ }^{21}$

The Bishops' Program of Social Reconstruction, as well as their Pastoral Letter, was largely based on the Pope Leo XIII's encyclical, Rerum Novarum. Published on May 15, 1891, the encyclical defined the role of the Church and state in society, arguing that the state existed to foster an environment that supported its citizens and their efforts towards legitimate ends, which the Church understood as the genesis of the family and its care, accomplished in working conditions that promoted the dignity of man. ${ }^{22}$ The next great social encyclical, Quadragesimo Anno, published by Pope Pius XI on the fortieth anniversary of Rerum Novarum, further defined the relationship between the state and its people through its principle of subsidiarity, which defined man as a being in relation to larger communities, and these communities in turn in relation to larger organizational bodies, such as the state. These communities - both large and small - share a responsibility to aid the individual in their pursuit of their own self-realization, which in turn helps foster the stability of society. ${ }^{23}$ In regard to the SAD and its social question, this meant that the SAD supported a system whereby labor and management worked together in the form of industry councils, which freed the state to pursue its main interests. In particular, Quadragesimo Anno affirmed the precepts of the Bishops Program of Social Reconstruction and its Pastoral Letter of 1919, supporting private property, the right to a living wage, the cooperation of management and labor, and the right of workers to organize.

From the outset of the creation of the SAD in 1919, Fathers John A. Ryan and Raymond McGowan served as its director and assistant director, respectively. John A. Ryan had ascended

\footnotetext{
${ }^{21}$ Ibid., $30-32$.

${ }^{22}$ William Murphy, A Century of Catholic Social Thought: Essays on 'Rerum Novarum' and Nine Other Key Documents, ed. George Weigel and Robert Royal (Lanham: University Press of America, 1991), 18.

${ }^{23}$ Thomas C. Kohler, A Century of Catholic Social Thought, 31.
} 
to the forefront of American Catholic Social thought by 1919, having penned the "Bishops' Program of Social Reconstruction" in that same year. In Higgins' own words, this program of social reconstruction was basically "the New Deal program, thirteen years before the New Deal." ${ }^{24}$ Like Higgins, Ryan had also earned his doctoral degree at the Catholic University of America. His dissertation applied the precepts of Rerum Novarum to America's economic policies, arguing that "wages should be sufficiently high to enable the laborer to live in a manner consistent with the dignity of a human being. $" 25$ This was the living wage advocated in Rerum Novarum, which asserted that a man's labor was tied to his human dignity. As a direct consequence, the wage contract held a social dimension which unregulated markets did not recognize, but which the Catholic was called to implement. For Ryan, the demands of Rerum Novarum, and the social encyclicals that followed, were ever present. Consequently, he set a course for the department which demanded the application of Catholic social principles in the pursuit of social justice.

While "Ryan interpreted and defended American reform in terms of Catholic thought, McGowan reversed the process, rigorously measuring reform proposals against 'the yardstick' of papal teachings and seeking to develop an independent Catholic program based on the occupational group idea." ${ }^{26}$ Such was the intent of The Yardstick, the bi-weekly Catholic column which McGowan wrote prior to Higgins's assumption of it in 1945. This was not the only service that McGowan provided at the NCWC, however. McGowan also organized and helped create the Catholic Conference on Industrial Problems (CCIP), since he saw a need for a top-down

\footnotetext{
${ }^{24}$ Higgins and Bole, Organized Labor and the Church, 27.

25 John A. Ryan, A Living Wage: Its Ethical and Economic Aspects (New York: Macmillan Press, 1906), viii.

${ }^{26}$ Costello, Without Fear or Favor: George Higgins on the Record, 19.
} 
movement, a national conference where local meetings could follow. ${ }^{27}$ The conference formed in December of 1922, and its primary purpose was to encourage dialogue between Catholic employers, laborers, and those who sought social action in industry. In order to encourage such dialogue, the conference meetings never conducted a vote on the issues at hand, especially that of industrial policy. The CCIP feared that employers would refuse to attend the meetings in anticipation of being outvoted on such issues. ${ }^{28}$ Consequently, while this encouraged dialogue, McGowan also fostered an organization which informed and educated those interested, involved, and affected by Catholic social action and labor issues. In this way, McGowan also differentiated himself from his contemporary, John A. Ryan. Ryan believed that the State was the only entity with enough authority and power to reform American economic life, while Fr. McGowan believed that the occupational group system advocated by Quadragesimo Anno was a more effective means of social change. McGowan did not hold the same faith in the government that Ryan exhibited, and feared that government intervention and domination was detrimental to the social order. Instead, he advocated the growth of voluntary labor associations as an integral part of a Christian social order. ${ }^{29}$ This undoubtedly had an impact upon Higgins and his career, as he too was involved in the CCIP by working closely with McGowan in preparation for its meetings, besides giving lectures at those meetings. ${ }^{30}$

Both Raymond McGowan and John A. Ryan influenced Higgins greatly during his early years as a member of the department. The Social Action Department, run by both Ryan and McGowan, was already known for its progressive social thought well before Higgins replaced

\footnotetext{
${ }^{27}$ For a more detailed analysis of the CCIP, please see Thomas R. Greene's "The Catholic Conference on Industrial Problems in Normalcy and Depression," Catholic Historical Review 77, No. 3 (July, 1991): 437 - 469.

${ }^{28}$ Greene, "The Catholic Conference on Industrial Problems in Normalcy and Depression," 443.

${ }^{29}$ David J. O'Brien, American Catholics and Social Reform: The New Deal Years (New York: Oxford University Press, 1968), 101.

${ }^{30}$ Besides these regional meetings, McGowan also started a Priest's Conference branch of the CCIP, where different diocesan priests from various dioceses met, discussed and studied the labor encyclicals.
} 
Father Hayes. And while Ryan's influence on Higgins is undeniable, Higgins was McGowan's student (at least in his early career) much more so than Ryan's. It was McGowan who invited Higgins to work at the NCWC in April of 1944. By the time Higgins joined the SAD, it "was, for all practical purposes, run by... [Ryan's] assistant”, McGowan. ${ }^{31}$ Such was made clear by Higgins in his biography written by George Costello, where he asserted that "McGowan really ran the department," and that "everything of a programatic [sic] nature came from McGowan.",32 This mirrors the assertion of Francis L. Broderick, Ryan's biographer, who claims that "for two hours a day, four or five days a week, - he was frequently away for three months in the summer Ryan did little more than answer his mail, dictate a lecture or an article, or consult briefly with someone from another department." 33 Given John A. Ryan's limited presence at the offices of the NCWC, it was McGowan who essentially ran those offices and supervised Higgins's work there. This was so much the case that Higgins felt comfortable telling Ryan's biographer that "much of what Monsignor Ryan did would have been done about as well and in much the same way if there had been no NCWC." ${ }^{34}$ Upon McGowan's death, he wrote to McGowan's sister that “Ray's death was a grievous loss to me personally.... Everything I know about Catholic social theory and Catholic social action I learned from him.... I owe him more than I can possibly calculate." 35

Defining Higgins's role within the SAD is difficult if only due to the various duties he performed within the department itself. In 1945 Higgins took over writing The Yardstick, a regular column written by McGowan that compared social reforms of the day in light of the

\footnotetext{
${ }^{31}$ Higgins and Bole, Organized Labor and the Church, 31.

${ }^{32}$ Costello, Without Fear or Favor, 19.

${ }^{33}$ Francis L. Broderick, Right Reverend New Dealer: John A. Ryan (New York: Macmillan Company, 1963 ), 121 122.

${ }^{34}$ Ibid., 121.

${ }^{35}$ George Higgins to Bess McGowan, Dec. 13, 1962, ACUA/GGH Papers, Box 156, Folder 9.
} 
encyclicals. The following year Higgins became the Assistant Director of the SAD, following McGowan's assumption of the directorship in the same year. In 1954 Higgins became the director of the SAD, serving in that capacity until 1967 when the NCWC became the United States Catholic Conference [USCC], which acted on behalf of the United States Catholic Conference of Bishops [USCCB]. Following this reorganization Higgins served as the Director of the Division of Urban Affairs until 1972, and then in various roles for the organization until his retirement in 1980. Even following his retirement, Higgins contributed to the labor movement in various ways, serving as a consultant for the USCC and its Department of Social Development and World Peace, as well as lecturing for the Catholic University of America's School of Social Science and its Department of Theology. The Yardstick remained a constant for Higgins until he wrote its final column on September 10, 2001, approximately one year prior to his death on May 1, 2002 at the age of eight-six.

If one were to define Higgins's greatest contribution to the $\mathrm{SAD}$, the one that stands in the foreground is his work as the American Catholic Church's leading expert on and liaison with organized labor. ${ }^{36}$ During his thirty-six years in the department Higgins befriended and developed close relationships with those who helped shape American labor policies, including some of the most influential labor leaders of the day. Among these were Philip Murray, President of the Congress of Industrial Organizations (CIO); George Meany, President of the American Federation of Labor and Congress of Industrial Organizations (AFL-CIO); I.W. Abel, President of the Steelworker's Union; Walter Reuther, President of the United Auto Workers (UAW); and Cesar Chavez, President of the National Farm Workers Association (NFWA). Higgins also maintained working relationship - and close friendships - with government officials like James

\footnotetext{
${ }^{36}$ John J. O'Brien, George G. Higgins and the Quest for Worker Justice: The Evolution of Catholic Social Thought in America (Lanham: Rowman and Littlefield, 2005), xiii.
} 
Mitchell, and Arthur Goldberg, both Secretaries of Labor, and in the case of Arthur Goldberg, a former Justice of the Supreme Court.

These relationships developed to such an extent that Higgins was privy to and took part in some of the more influential events, circumstances, and organizations in twentieth century American labor history. A primary example of such a circumstance rests in Higgins's work alongside Arthur Goldberg during the merger of the American Federation of Labor with the Congress of Industrial Organizations in 1955. While Goldberg drew up the legal briefs for the unification of the two unions in February of that year, Higgins complemented his work by advising the principal parties involved with the merger. Their work was well rewarded, as the two unions joined forces at their first annual convention on Dec. $5,1955{ }^{37}$ It was a watershed moment for the American labor movement; the merger of the AFL-CIO brought together the two of the largest and most influential unions under one roof, reuniting the unions after the CIO's split from the AFL in 1937. Although Higgins would later deny a direct role in bringing about the merger, his work during that period was well appreciated. As a sign of gratitude, the leadership of the newly formed AFL-CIO asked Higgins to perform the opening invocation at the first convention. ${ }^{38}$

Besides his involvement with the AFL-CIO, Higgins joined the United Auto Workers (UAW) Review Board in 1957. He later became its chairman in 1962, serving in that capacity until his retirement as an officer in 2000 . As a member, he took part in the many cases before the board concerning the discipline, promotion, and termination of the union's members. Consequently, Higgins also attended the majority of the union's annual meetings, often

\footnotetext{
${ }^{37}$ Arthur Goldberg, AFL-CIO: Labor United (New York: McGraw-Hill Book Company, 1964), 87 - 98.

${ }^{38}$ Costello Interview with Higgins, no listed date, ACUA/GGH Papers, Box 435, Folder 19.
} 
celebrating mass and preaching sermons to those attending. Higgins also worked as a consultant for the Bishops' Ad Hoc Committee on Farm Labor, where he served as a frequent companion to Msgr. Cardinal Roger Mahoney, as they investigated the claims of both the growers and the NFWA in the California grape conflicts of the early 1970s. ${ }^{39}$ While in the SAD, Higgins spoke out on a number of national boycotts and strikes as well, including the Kohler strike of 1962; the Campbell and Nestle boycotts in 1980; and the J.P. Stevens boycott in 1980.

Such was the nature of his work that following his "retirement" from the USCC in 1980 he expressed his consternation that the department had not trained anyone to replace him in this regard.

I stayed here [in the department] long enough to establish a contact with the labor movement that couldn't have been developed in any other way... I'd say in all modesty that if they found a priest tomorrow for the staff and told him, 'The only thing we want you to do is keep in touch with the labor movement,' he couldn't do it in less than five years. Or 10 years. It would take him that long to get his credibility established... A fellow would have to be here 10 years before they'd even let him in the [UAW] hall. ${ }^{40}$

While his work within the SAD allowed him to develop and foster the labor relationships that would allow him to influence the movement, it was The Yardstick that provided Higgins with a voice to guide and influence the developing social order of the times. This was a church and social order developing quite differently from the American Catholic Church prior to the 1920s. In the years preceding Higgins' tenure at the NCWC, the American Church had experienced a new wave of immigration from Eastern Europe, Catholic immigrants who

\footnotetext{
${ }^{39}$ During the period of his work as secretary for the Bishops' Ad Hoc Committee, Mahoney was a diocesan priest of the Monterey-Fresno diocese, which later split in two. While serving as a priest for Monterey-Fresno, Bishop Aloysius Willinger served as its ordinary. Following its split, Mahoney served under both Timothy Manning and his successor, Hugh Donohoe, in the Fresno diocese. Mahoney became the auxiliary bishop of Fresno in 1975, and later became bishop of Stockton, California in 1980. Five years later Mahoney became the Archbishop of Los Angeles, and received his red hat in 1991.

${ }^{40}$ Costello, Without Fear or Favor, $67-68$.
} 
ethnically differed from the Irish and Germans who came before them, and who were, like earlier new-comers, poor, uneducated, and unskilled. Once again, Catholic immigrants banded together in ghettos where the traditions, customs, language, and values of their homelands could be preserved. $^{41}$ This subculture created conflict within American culture at large, for immigrants had, as David O'Brien put it, "to reconcile this emphasis on primary loyalty to the church with civic obligation in a pluralistic society. The answer was to claim that Catholics were better citizens, more ardent patriots, and more moral people precisely because they were Catholics." ${ }^{\prime 2}$ As to how Catholics would be better citizens, this remained open to debate, especially among the different factions of the American Catholic hierarchy.

Protection of Catholic immigrants rested in the hands of their bishops, who more often than not exercised this protection through strict control. The ethnic composition of the American hierarchy during this period was still largely Irish, who, as Dolores Liptak in Immigrants and their Church points out, "manifested a paternalistic, even controlling, attitude toward the development of the local church. ${ }^{, 43}$ Thus, for the majority of the American church, the bishop and his pastor held the ultimate authority in the decisions of the local church. This was a fact readily acknowledged by those who worked with the local clergy, that while lay members of the church might aid in the priests' ministry, they did not share any of his authority. ${ }^{44}$

\footnotetext{
${ }^{41}$ For a much more detailed treatment of Catholic immigrant ghettos of the period prior to Higgins' tenure, please see Robert Orsi, The Madonna of $115^{\text {th }}$ Street: Faith and Community in Italian Harlem, 1880 - 1950 (New Haven: Yale University Press, 1985); Dolores Liptak's work, Immigrants and Their Church (New York: Macmillan Publishers, 1989), also serves as an excellent resource in regards to American Catholic immigrant history as a whole, and in particular the cultural divide that existed between the American hierarchy and the differing ethnic compositions of immigrants from 1880 to 1930.

${ }^{42}$ David J. O’Brien, Public Catholicism (Maryknoll: Orbis Books, 1996), 61.

${ }^{43}$ Dolores Liptak, R.S.M., Immigrants and Their Church (New York: Macmillan Publishing, 1989), 82.

${ }^{44}$ Ibid., 83, 84; The Irish composition of the American hierarchy presented its own problems, as many different ethnic minorities within the American church railed against the dominance of the Irish.
} 
With such a large contingent of the American Church comprised of immigrants, it is no surprise that a significant number of its members were involved in industrial labor. The Church had recognized early on the need for labor mediation due to the actions of the Molly Maguire episodes of the late 1870s, but prior to 1885 the American Church was involved very little in regard to the labor movement. Trade unionism had achieved very little in the way of recognition by Catholic circles, which according to Aaron I. Abell demonstrated that laissez-faire principles had influenced Catholics at large. Besides this, the hierarchy of the Church feared that workingmen's associations were largely responsible for the physical violence of the conflict between capital and labor, evidenced by the tactics of the Molly Maguires. Consequently, they remained reluctant to take a stand on the issue. ${ }^{45}$ This would not change until the intervention of Cardinal James Gibbons and his defense of the Knights of Labor in $1887 .{ }^{46}$ Even so, Catholic causes of social justice remained limited to local circumstance, of which the work of labor priest Father Peter Dietz serves as a primary example. ${ }^{47}$

The changes the American Church faced during these years would continue during Higgins' tenure at the Social Action Department of the NCWC. In the same year that Higgins joined the department, the Serviceman's Readjustment Act of 1944, better known as the G.I. Bill, also provided Catholic veterans the means to a better education, as well as finance

\footnotetext{
${ }^{45}$ Aaron I. Abell, American Catholicism and Social Action: A Search for Social Justice, 1865 - 1950 (Notre Dame: University of Notre Dame Press, 1963), 47.

${ }^{46}$ Gibbons defended the Knights of Labor by persuading the Vatican to repeal its condemnation of the organization. In his address to the Holy Office, he argued that it was "not only the right of the laboring classes to protect themselves, but the duty of the whole people to aid them in finding a remedy against the dangers with which both civilization and the social order are menaced by avarice, oppression, and corruption." By condemning such an order - an order apart from the Masons who were seen as hostile to the Church - the Church might "lose the heart of the people... [which] would be a misfortune for which the friendship of the few rich and powerful would be no compensation." These citations are from John Tracy Ellis, ed., Documents of American Catholic History (Milwaukee: The Bruce Publishing Co., 1956), 464; Ibid., 469.

${ }^{47}$ Dietz established the Militia of Christ in 1910, which served as a labor organization for Catholic members of the American Federation of Labor. Its stated purpose was to educate the Catholics of the A.F. L., but more so to combat the dangers of socialism within the A.F. L. itself.
} 
opportunities for small business. Consequently, it was during Higgins' time that many Catholics, the same Catholic families that had emigrated to the U.S. in the 1920s, moved from labor to small business ownership, and thus moved from the lower to middle class. Meanwhile, the hierarchy still defined the role of the laity in Catholic Action as subordinate to the hierarchy, but lay members involved in Catholic social action did not necessarily define themselves along the same lines. New groups were forming that understood the need for lay autonomy, such as Young Catholic Workers and the Catholic Family Movement, and they wished to engage American culture at large in new and personal ways. Among such new and personal ways was the effort to change social institutions, as opposed to simply converting the individual or promoting an individual responsibility to social justice. By applying terms of social justice to social institutions, lay members of the Church became more involved in their secular professions, and promoted nondenominational efforts for reform. In this sense, many Catholics were applying their Catholicism to their everyday lives, and as such were fighting against the secular tide that removed their religious identity from daily life. ${ }^{48}$ In a real sense, the American Catholic laity had come into their own following the Second World War, just as Higgins took his first steps under the tutelage of McGowan and Ryan at the National Catholic Welfare Conference and its Social Action Department.

When reading Higgins's Yardstick columns it is evident that as a labor priest Higgins sought a form of social justice that promoted the common good through a system of shared responsibilities according to one's place within a company. Higgins took over The Yardstick from McGowan in 1946, having written nine columns for McGowan in the previous year. Disseminated by the NCWC News Service and sent to Catholic newspapers around the country,

${ }^{48}$ David J. O’Brien, Public Catholicism, 210. 
the same newspapers could decide whether or not to publish the column, as well as what title said column would take. ${ }^{49}$ In his columns he addressed the social issues and events of the day, relating them back to "the yardstick" of papal teaching. In particular, he argued for the creation of the social order as described in the social encyclicals of the Church, especially that of Quadragesimo Anno. Pius XI's encyclical, as Higgins and those of the SAD understood it, demanded a socio-economic order which promoted the common good of the community (and through the community the individual) above all else. The best way to achieve such an order demanded the organization of all aspects of economic life, which they understood as trade associations, agricultural cooperatives, industry, and labor. Once fully organized these entities would band together to form a federation of Industry Councils which would work with the State to guide the economic life of the nation through industry-wide collective bargaining.

John J. O'Brien, in George G. Higgins and the Quest for Worker Justice, argues that the basis for Higgins's viewpoint, besides the directives of such encyclicals as Quadragesimo Anno and Rerum Novarum, lies in Higgins's understanding of social justice as defined in Divini Redemptoris. Written by Pope Pius XI and published on March $19^{\text {th }}, 1937$, the encyclical described the threat of communism in stark terms. As a revolution, communism exceeded "in amplitude and violence anything yet experienced in the preceding persecutions launched against the Church," and if it remained unchecked, civilization was in danger "of falling back into a barbarism worse than that which oppressed the greater part of the world at the coming of the Redeemer.” In terms of social justice, Pius XI argued that communism presented a "pseudo-ideal of justice," whose doctrines were based on the belief that "human society is nothing but a phenomenon and form of matter," which through "a perpetual conflict of forces ... moves

\footnotetext{
${ }^{49}$ John J. O’Brien, George G. Higgins and the Quest for Worker Justice, 77.
} 
towards the final synthesis of a classless society." Such a belief system had "no room for the idea of God," or the "survival of the soul after death nor any hope in any future life."50 The Church's ideal of justice stood in opposition to the communist understanding. Rather than a conflict of forces, the Church defined justice in social terms based on the Christian concept of charity. The virtue of charity demanded the recognition of the dignity of the human person, and by its recognition, society benefited as a whole. Simply put, social justice was "that virtue which demands from each individual all that is necessary for the common good." ${ }^{\text {51 }}$ All men were bound by this precept, a social obligation "from which neither employers nor workingmen can escape."

While Divini Redemptoris certainly influenced Higgins's views of social justice, his time at the Social Action Department under Raymond McGowan's tutelage would have been more immediate. Under McGowan's guidance, the SAD initiated a program which promoted the principals of Quadragesimo Anno and its Industry Council Plan. Higgins, as a member of the department, and McGowan's protégé, also worked for its implementation, and so sought a change in the social order of the day. Arguing that the structures for the Industry Council already existed within America, particularly those found within American unions, Higgins argued for the CIO's industry council plan of 1946 as the closest accommodation to the Industry Council Plan found in Pius XI's encyclical. He asserted that

\footnotetext{
${ }^{50}$ Pope Pius XI, Divini Redemptoris, March 3, 1937, http://www.vatican.va/holy_father/pius_xi/encyclicals/documents/hf_p-xi_enc_19031937_diviniredemptoris_en.html (accessed 10.28.2013).

${ }^{51}$ Pius XI, encyclical, Divini Redemptoris, as cited in George G. Higgins, The Yardstick, May 5, 1947, ACUA/GGH Papers, Box 343, Folder 14.

${ }_{52}$ Pope Pius XI, Divini Redemptoris, March 3, 1937, http://www.vatican.va/holy_father/pius_xi/encyclicals/documents/hf_p-xi_enc_19031937_diviniredemptoris_en.html (accessed 10.28.2013).
} 
Nature itself intends them to organize for this purpose-to "form guilds or associations" and through these self-governing associations to regulate economic life according to the requirements of social justice. Each industry forms a separate "order" and the various industries, thus organized, are to work for the common good. Together they form the Social Order whose function it is in cooperation with government, to "give form and shape to all economic life. ${ }^{53}$

Consequently Higgins, along with the SAD, called for self-governing associations to regulate economic life in a cooperative effort for the common good, and these associations would work with the government, which held the final say in their coordinated efforts.

Higgins's attraction to the CIO's industry plan not only stemmed from its similarity to the Industry Council Plan espoused in Quadragesimo Anno, but its similarity to the Catholic principle of subsidiarity defined in Pius XI's encyclical. This principle states that “"'just as it is gravely wrong to take from individuals what they can accomplish by their own initiative and industry and give it to the community, so also it is an injustice and at the same time a grave evil and disturbance of right order to assign to a greater and higher association what lesser and subordinate organizations can do." ${ }^{54}$ In this sense, Higgins's interpreted the government's role, or for that manner any human institution, was to assist and advise, not dominate and control. It is no coincidence that such a system coincided with the Church's own spiritual vision, for as Higgins understood it

It is the Mass that matters most even in the political order and especially in a democracy. Democracy is based on a sense of the priceless dignity and worth of the individual man coupled with a sense of the dependence of all men on one another - a sense of working together to make it succeed.... The spiritual force for the development of this fellowship comes from Christ, from the Mystical Body. The great embodiment of this force in the world today is the liturgy and especially the Mass, which is Christ and people acting together.

\footnotetext{
${ }^{53}$ George G. Higgins, “An Organized Economic Society,” The Yardstick, April 24, 1950, ACUA/GGH Papers, Box 344, Folder 10.

${ }_{54}$ Pius XI, encyclical, Quadragesimo Anno, no. 88, as cited in George G. Higgins, "The Industry Council Program," The Yardstick, November 18, 1946, ACUA/GGH Papers, Box 343, Folder 12.
} 
[The] Mass shows forth the supreme worth of the individual. The individual is present at Mass as a divinized creature, and the Mass in turn enhances that divinization, that supreme worth. But the individual is also present at Mass as a member of the group - acting, giving, receiving, worshiping together with his fellow Catholics. 55

The fact that Higgins tied social action to the Mass should come as no surprise, given his background at St. Mary's seminary and the influence of Msgr. Hillenbrand. Hillenbrand was a dedicated follower of the liturgical movement espoused by Virgil Michel, who as founder of the Liturgical Press and Orates Fratres, served as the official voice of the movement. ${ }^{56}$ The movement had been validated by Pope Pius XII's Mediator Dei, published on November 20, 1947, which served to justify Hillenbrand's promotion of liturgical innovation during his term as rector. Consequently, according to Robert Tuzik, who wrote his dissertation on Hillenbrand, the rector of St. Mary's spent

a good portion at the beginning of the year on the doctrine of the divine life and the Mystical Body, because without understanding these it is quite useless to talk about the details of the Mass and the historical elements that enter into the Mass.

The course must have in mind that the people need what Pius $X$ advocated, an active participation in the Mass and in the divine office. Only the doctrines of the supernatural life and the Mystical Body will give both priests and laity the proper background for active participation....

The rest of the year is devoted to taking up the Mass itself, step by step, explaining the meaning and some of the history, some of the practical objectives,

\footnotetext{
${ }^{55}$ George G. Higgins, “"First and Foremost Remedy,” The Yardstick, May 8, 1961, ACUA/GGH Papers, Box 347, Folder 6.

${ }^{56}$ Orates Frates was the official journal for the liturgical movement, founded by Virgil Michel in 1925. It's title means "Pray, Brethren," which also serves as the beginning of the prayer by the Catholic priest inviting the community of the faithful to participate in the Eucharist. The title of the journal changed to Worship in 1951.
} 
possibilities of active participation, relationship to the whole structure of the Mass, etc. ${ }^{57}$

This view of the liturgy and the Mass by Hillenbrand had a direct impact upon Higgins's views of social justice, especially since Hillenbrand, as rector, argued that the "problems of society were due to a false philosophy (secularism and individualism), which had created an unjust economic order." According to Hillenbrand, its remedy "was to restore the organic basis of society and the true Christian spirit of self-sacrificial love," which could only be accomplished by the "active participation in the liturgy and the creation of lay apostles who would share in the apostolate of the hierarchy." ${ }^{58}$ Ultimately, as Higgins himself acknowledged in his Yardstick columns, both he and Hillenbrand understood the liturgy as the corporate worship of the Mystical Body, and by doing so, both believed that if the people were "united with Christ in the corporate worship of the church, then they will be united with Christ in continuing his mission in the world." ${ }^{59}$ For Higgins, this continuing mission was a mission of social justice.

It is this same liturgical outlook that differentiates Msgr. Higgins from that of his predecessor, Msgr. John A. Ryan. As Ryan’s biographer notes, Ryan “was untouched by, perhaps even unaware of, the liturgical revival spreading afar from St. John's Abbey in Collegeville, Minnesota, just sixty miles from St. Paul." Even the "great Benedictine liturgist, Dom Virgil Michel, believed that Ryan relied too much on legislation and on the state, that (in the words of Michel's biographer) Ryan made 'too little insistence on the absolute need of the spiritual in social reform and on the need for a general spiritual revival for a complete program

\footnotetext{
${ }^{57}$ Robert Tuzik, "The Contribution of Msgr. Reynold Hillenbrand (1905 - 1979) to the liturgical movement in the United States: Influences and Development" (PhD diss., Notre Dame University, 1989), 42 - 43.

${ }^{58}$ Ibid., $162-163$.

${ }^{59}$ Ibid., $170-171$.
} 
of Christian social regeneration." "60 This was not the case with Higgins, who himself had noted Michel's assessment that the "Catholic social action movement symbolized by Ryan had concerned itself too much with reform of social and economic institutions and not enough with moral and spiritual reform." This certainly had an impact on Higgins' own efforts at social reform, since Michel's judgment “served as a constant reminder throughout my own [Higgins's] social ministry.",61

This particular theological outlook served Higgins well with the advent of the Second Vatican Council, in particular his work with the preparatory commission on the lay apostolate. In 1961 Higgins was asked to serve as a member of that preparatory commission, which dealt in large part with the place of the laity within the life of the Church, as well as "Catholic Action". ${ }^{6}$ At this time these two issues were of primary importance within the American Church, if not the universal Church, as the meaning and scope of Catholic Action was under debate. This debate also included discussion of the level of dependence of Catholic lay members upon the hierarchy in such social efforts, and whether Catholics could take part in social organizations that included non-Catholics. Catholic Action had not been defined under these terms by the Church, which explains why some groups, like the Catholic Worker Movement under Dorothy Day, felt justified in their work outside the approval or guidance of the hierarchy. Consequently, the commission focused on such issues as the scope of the apostolate, how it could be adopted to meet contemporary needs, as well as the notion of Catholic Action, and how both it and the lay apostolate were meant to interact with the hierarchy. ${ }^{63}$

\footnotetext{
${ }^{60}$ Broderick, Right Reverend New Dealer, 242.

${ }^{61}$ Higgins and Bole, Organized Labor and the Church, 14.

${ }^{62}$ George Higgins to Joseph Ligutti, January 7, 1961, ACUA/GGH Papers, Box 36, Folder 15.

${ }^{63}$ Guiseppe Alberigo \& Joseph A. Komonchak, History of Vatican II, Vol. I: Announcing and Preparing Vatican Council II Toward a new Era in Catholicism (Maryknoll \& Leuven: Orbis and Peeters Publishers, 1995$), 197$.
} 
The commission produced a single 172 page text, "Schema Constitutionis de apostolatu laicorum", which proposed that all members of the church have a right and a duty to be actively involved in the life of the Church. It defined the laity as "Christian believers to whom the common rights and duties of persons in the Church belong and who, while not belonging to the clerical state or to the state of perfection [i.e., members of religious orders], are called to attain their Christian perfection amid the affairs of the world." 64 The text also discussed Catholic Action directly, and defined it as those forms of lay activity directly under the supervision and direction of the hierarchy. This definition did not prevent lay Catholics from taking part in “mixed or neutral associations," however. In addition to defining Catholic Action, the commission asserted that the laity should take part in charitable organizations that operated outside the supervision and direction of the hierarchy, whether those were run by the state or by secular institutions. Consequently, lay Catholics could now participate with non-Catholics without fear of betraying their faith or religious principles. ${ }^{65}$

While at the Council, Higgins served as a member of the American daily press panel, which offered a briefing of the day's events to reporters. In particular, Higgins again served as mediator, intervening "anytime there was a gripe about press relations... [but also showing] the bishops that the more information they supplied, the less misinformation would be published by the press." 66 Besides this public contribution, Higgins also worked "behind-the-scenes" of the

\footnotetext{
${ }^{64}$ Ibid., 198.

${ }^{65}$ Following this service, Higgins also made sure that an invitation to the Council would follow, writing Msgr. Ligutti, a fellow preparatory commission member who at the time was residing in Rome, requesting that he determine whether the members of the preparatory commission would be invited to attend the Council, and if not, whether there might be any objection as to whether they could serve as consultants. According to the correspondence between them, Ligutti did request Higgins' inclusion at the council as a peritus, while Higgins secured a position of that of a consultant to Coleman Carroll, the bishop of Miami, FL, in case the invitation to serve as a peritus never materialized. Fortunately, Higgins did receive his invitation to be a peritus shortly before the Council (George Higgins to Joseph Ligutti, July 30, 1962 and Sept. 9, 1962, ACUA/GGH Papers, Box 36, Folder 15).

${ }^{66}$ Costello, Without Fear or Favor, 129.
} 
Council through his work on the declaration of the relation of the Church to non-Christian religions, Nostra Aetate. Contacted by Malachi Martin, who was then serving as an advisor to Cardinal Augustin Bea, the president of the Pontifical Council for Promoting Christian Unity and the main force for that conciliar decree, Higgins served as the liaison between Bea, the American bishops, and the American Jewish community. ${ }^{67}$ And while the document did not go as far as many hoped in its treatment of the Jewish faith, it did provide the grounds for continuing the work after the close of the Council in 1965.

Following the Council, Higgins went to work realizing the decrees set forth therein, particularly that of Nostra Aetate. His greatest contribution along these lines lay in his work setting up the American Secretariat for Catholic-Jewish Relations in 1967. Serving as the aid to Bishop Francis P. Liepzig of Baker, Oregon, the chair of the Committee for Ecumenical and Interreligious Affairs, Higgins hand selected Fr. Edward H. Flannery, author of The Anguish of the Jews: Twenty-three Centuries of Anti-Semitism, as its Executive Secretary, and then served as a member of both the committee and its Board of Consultors. The American Secretariat aided all dioceses of the American Church in the implementation of the guidelines set forth by Nostra Aetate, particularly those concerning modifications to Catholic liturgical practices and their references to the Jewish people. By doing so, the Secretariat hoped to promote a deeper understanding of Jewish theology, as well as the current theological standing of the Church on those of the Jewish faith. In reality, the Secretariat did much more than educate the American Catholic laity on these issues, as current events, such as the Israeli Arab War of 1967, forced the Secretariat to address a greater range of issues than it originally intended, eventually leading to a theological recognition of the right of Israel to exist.

\footnotetext{
${ }^{67}$ Malachi Martin was also a professor of paleontology at the Pontifical Biblicum Institute in Rome. He would later leave the Jesuits, and begin a successful writing career which focused on the life of the Church.
} 
It was also during his work on the Secretariat for Catholic/Jewish Relations that the NCWC, in response to the mandate of the Council, reorganized into the United States Catholic Conference of Bishops [USCCB], and its Secretariat, the United States Catholic Conference [USCC]. Meeting the demand of the Second Vatican Council, the body of bishops began the reorganization in 1966 with the aid of the consulting firm, Booz, Allen, and Hamilton. Consequently, the organizational structure guiding Higgins' work in the field of social justice changed significantly, and to a certain degree the past goals of NCWC, as it formed its new organization. Among these changes was the restructuring of Higgins's former department, the Social Action Department, into the Division of Urban Affairs in 1967, which later became the Secretariat for Social Development and World Peace in 1972. It was a process that would take six years to complete, and soon following its restructuring, Higgins changed his role from director to research consultant within the new organization in 1972. Higgins would serve in this role until his retirement in 1980.

This was not the only demand on Higgins during this period of the late 1960s and early 1970s. Besides his work in the American Secretariat for Catholic-Jewish Relations and the reorganization of the NCWC, Higgins devoted much of his time to the Bishops' Ad Hoc Committee, which sought to mediate the conflict between the grape and lettuce growers of California with the farmworkers they employed. Created in November of 1969, the Bishops' Ad Hoc Committee sought to mediate the Delano Grape Strike, which had been ongoing since September of 1965. Cesar Chavez and his fledgling National Farm Workers Association (NFWA) - later to become the United Farm Workers Organizing Committee (UFWOC) - had been fighting the Delano Grape growers in order to secure certain rights for the farmworkers, such as their right to organize and bargain collectively, requiring growers to use hiring halls, as 
well as farmworker control of which pesticides would be used by the growers. Ultimately, Chavez's tactics settled on the use of the boycott in order to force the grape growers to bargain with the union. It was his request that the USCC/NCCB back this boycott that led to the creation of the Ad Hoc Committee, and led to their offer of mediation between the workers and growers. Higgins served as a consultant to the Committee, of which John Donnelley, the Bishop of Hartford, Connecticut served as chairman.

Within a short period Higgins and the other members of the Ad Hoc Committee were successful, and on July 29, 1970 all twenty-six of the principal growers had signed union contracts with the UFWOC. The Ad Hoc Committee never had to endorse the boycott favoring Chavez, and had successfully mediated the dispute. This was not to last however, for on the same day the contracts had been signed, the Teamsters signed sweetheart deals with the lettuce growers of Salinas valley, breaking a July 21, 1967 accord with the UFWOC which had given the UFWOC jurisdiction over the valley, while at the same time centralizing Teamster rights to organize industries in the area. Chavez and the UFWOC went to war, again employing the boycott, but this time against the lettuce growers of the UFWOC, and again asking the USCC/NCCB for aid. In return, Higgins and his contemporaries mediated several settlements between the Teamsters and Chavez's union, only for those contracts to be immediately broken each and every time by the Teamsters. Consequently, the Ad Hoc Committee convinced the USCC/NCCB to set aside its neutrality and endorse the boycott of Chavez and the UFWOC, arguing that it would do so until the farmworkers gained the right to secret elections by ballot which would determine which union they wished to represent them, either the Teamsters or the UFWOC. It would not be until the enactment of the California Agricultural Labor Relations Act that the Ad Hoc Committee ended its endorsement of the boycott, since its aims of union 
elections had been achieved. Higgins acted as mediator and consultant for Donnelley and the interested parties of the USCC/NCCB throughout the entire affair.

With the close of the Salad Bowl Conflict and the enactment of the CALRA in August of 1975, Higgins turned his focus towards those who worked for the institutions of the Catholic Church in America. In particular he addressed the Church's own willingness - or lack thereof to allow its workers to organize, especially in Catholic hospitals and other health care facilities. Recognizing that those who worked in Catholic institutions are "much like rank-and-file workers in any other large-scale operation", Higgins argued that it meant, "at the very least, that church leaders and administrators of church-related institutions must unequivocally recognize the right of employees to organize, if the workers so desire, for the purpose of collective bargaining. ${ }^{68}$ In his editorials Higgins demanded that the Church live up to its own decrees concerning labor, ownership, and the rights of the individual.

Unfortunately, this created some turmoil among the American hierarchy, which may have played a role in the USCC/NCCB's attempt to retire Higgins early, as opposed to his mandatory retirement scheduled in 1980. According to those within the USCC/NCCB, particularly Bishop Thomas Kelly, O.P., the USCC/NNCCB general secretary, the conference had decided to close Higgins' office for budgetary reasons in December of 1979, a full year before his official retirement was scheduled to take place. ${ }^{69}$ The decision immediately generated a wave of protests, among them being that of Arthur Goldberg, who complained to the USCC/NCCB president, Archbishop John R. Quinn of San Francisco, in person. Within a short time the USCC/NCCB reversed course, due to what they claimed was the public misperception of their actions. ${ }^{70}$ Many within the American Church did not believe those within the hierarchy had made as simple

\footnotetext{
${ }^{68}$ Higgins and Bole, Organized Labor and the Church, 115.

${ }^{69}$ The scheduled retirement was mandatory for Higgins at this time.

${ }^{70}$ Gerald M. Costello, "George G. Higgins: Profile of a Priest," America, Oct. 25, 1980.
} 
mistake in their attempt to retire Higgins early, but rather had done so with prejudice. In particular, the interviews conducted by Costello point to a confluence of events surrounding the reorganization of the NCWC into the NCCB and its secretariat, the USCC, which undermined Higgins continued role within the new organization as he adopted more of consultant-like position within the department.

Following the reorganization of the NCWC, many began to question Higgins' place within it, specifically his work under John Cosgrove, who had assumed directorship of the Secretariat for Social Development and World Peace of the USCC/NCCB in 1972. Higgins had devoted much of his time to Cesar Chavez and the Farm Workers' Labor Movement, so much so that if the USCC/NCCB had decided to disband the ad hoc committee on the migrant worker question, many of his contemporaries believed that Higgins would have been "out... on a limb". ${ }^{71}$ Complicating matters, many within the USCC/NCCB questioned Higgins influence over Bishop Joseph Donnelly, the chairman of the Ad Hoc Committee, as well as the appropriateness of its work.

At the same time, Higgins's support of employees within Catholic institutions and their right to organize and bargain collectively had received notice. The issue was particularly important to Cardinal John Krol, Archbishop of Philadelphia and President of the USCC/NCCB from 1971 to 1974 . Krol had warned Higgins about his support of collective bargaining within Catholic institutions, particularly those of Catholic education, telling Higgins that the Church would "challenge every attempt of government to impose regulation over our schools", which the Supreme Court had deemed "too religious for government aid and which the N.L.R.B.

\footnotetext{
${ }^{71}$ James Rausch, interview by George Costello, Phoenix, AZ, February 21, 1980, ACUA/GGH Papers, Box 437, Folder 16, 6 .
} 
[National Labor Relations Board]" deemed not religious enough "for government entanglement and regulation." 72

Neither was Cardinal Krol the only high ranking American Catholic prelate to question Higgins and his loyalties to Catholic causes during this time. While Higgins was staunchly opposed to abortion, in the same breath he understood this important Catholic issue in the context of a greater social fabric. As a consequence, Higgins feared that abortion was becoming a "single topic" issue for Catholics as voters, and by becoming such, it threatened to undercut the social justice movement as a whole. Unfortunately, this stance created conflict between Higgins and his peers. Cardinal Patrick O’Boyle, who as the archbishop of Washington, D.C. had jurisdiction over Higgins, serves as a primary example in this regard. Writing to Higgins, the archbishop asked him "to remember that abortion is murder and you do not deal with murderers with kid gloves on and spats and a lot of sophistication."73 Undoubtedly, Higgins's stance on abortion generated conflict. Unfortunately, the historical record is limited for the period surrounding the attempt by the USCC/NCCB's leadership to retire Higgins early. What evidence there is, suggests that the budgetary effort of the USCC/NCBB to retire Higgins was likely valid, but with questionable contingencies on the part of its administrators.

The importance of Higgins' work, both within the confines of the Church and outside of it, lies not only in his contribution to the labor movement in America, but also in his contribution to the development of the American Catholic Church in these fields. In particular, through Higgins's work as a labor mediator and representative, he helped forge a new understanding of social justice and how it related not only to the public at large, but to individual Catholics, their country, and their faith. Furthermore, this work also contributed to a new understanding of the

\footnotetext{
${ }_{72}^{72}$ John Krol to George Higgins, October 18, 1976, ACUA/GGH Papers, Box 50, Folder 18.

${ }^{73}$ Patrick O'Boyle to George Higgins, July 29, 1976, ACUA/GGH Papers, Box 47, Folder 7.
} 
laity and its place within both the Catholic world and the world at large; an understanding which empowered lay members of the Catholic Church in ways they had not previously experienced. In many ways Higgins is responsible for the empowerment of lay Catholics, and their decision to act without asking for the direction or assent of the hierarchy. By including elements of the liturgy in his quest for social justice, something his predecessors had not done, Higgins served as a herald of many of the changes found at the Second Vatican Council, especially those concerning the place of the laity and their role within the universal Catholic Church. Particularly, in Higgins's later years he applied the same principles of subsidiarity back on the Church as a human institution. This in turn led him to support those workers in Catholic institutions, especially its centers for education and its hospitals, and their right to organize.

It is true that George Higgins focused largely on American labor relations and their relation to the American Church during his tenure at the Social Action Department of the NCWC. But in doing so, he addressed the social order as a whole in regards to Catholics in the world, and in particular those within the United States. Higgins's primary concern was the loss of Christian perspective from social action, or that secularization of social action would win the day. Throughout this period Higgins consistently sought to guide Catholics through the Yardstick, and used his presence and influence at the Social Action Department to preserve social action as a part of American Catholic identity. He did so during a time when Catholics in America were undergoing great cultural change. As a result, Higgins stands as one of primary individuals of influence both in the American Catholic church and in the labor movement during the twentieth century.

The following chapters will investigate these efforts by Higgins in greater detail, and will expand upon the material that has been presented in this introduction. This begins with Higgins's 
first days working at the Social Action Department, and the influences that shaped him for years to come. In particular, the following chapters will focus on the Industry Council Plan and its promotion by Raymond McGowan, who became the director following John A. Ryan's death in 1945. 


\section{Chapter 2}

\section{McGowan as Director: Higgins's Introduction to the Social Action Department}

There is a middle way between free competition and collectivism -- a way which is described in Quadragesimo Anno... as the Industries and Professions system.

- $\quad$ Rev. George G. Higgins, The Yardstick, Dec. 23, 1946

$$
\phi
$$

When George G. Higgins joined the Social Action Department full time in 1944, it was in a state of transition. Raymond McGowan, serving as Assistant Director, had already assumed the majority of responsibilities for running the department, especially in light of John A. Ryan's failing health. Consequently, when Ryan passed away on September 16, 1945, the transition to Director was an easy one for McGowan and the staff of the SAD. After becoming Director, McGowan set about making his own mark on the department. In particular, he promoted the Industry Council Plan espoused in Pope Pius XI's Quadragesimo Anno, and by doing so hoped to complete that which the bishops of 1919 had left for future generations - a "comprehensive scheme of [social] reconstruction." It was through McGowan's influence that Higgins learned all about Catholic social thought and action, which certainly included his experience at the SAD. Consequently, the Social Action Department and its director stand as one of the most important influences in the life of Higgins, as well as the social agenda McGowan hoped to institute under the authority of the department.

\footnotetext{
${ }^{1}$ Our Bishops Speak: National Pastorals and Annual Statements of the Hierarchy of the United States (Milwaukee: Bruce Publishing Company, 1952), 248.
} 


\section{Higgins Arrival: The State of the SAD in 1945}

The Social Action Department had existed for twenty-five years prior to George G. Higgins's arrival, created as a department of the National Catholic Welfare Council in 1919. As a department, the SAD fought against the same secularism that the NCWC itself hoped to combat. From the viewpoint of the organization, secularism was a disease spreading throughout the whole of American society, especially in the arena of labor and industry. Consequently, both the NCWC and the SAD understood the world as a place which housed a "growing irresponsibility of industry, futility and atheism in education, ineffectual religion in Protestantism, and a relentless system of greed and organized power in society." It was a social order that American Catholicism was unprepared to handle at the time, but hoped to address through the works of the newly established NCWC. ${ }^{2}$

The initial response of the SAD was to focus on the education of the American church, particularly those involved in industry and labor, believing that an informed laity and clergy might bring about a more immediate change to the social order. The main thrust of its efforts came in the form of its publications, which included a weekly press service that covered economic events, as well as its "Labor journals." In particular, the press releases sought to apply Catholic social principles to current social and industrial struggles, and by doing so provide solutions to the problems that both labor and capital faced. ${ }^{3}$ Besides these weekly press releases, the SAD published many articles on the social question and its current state in the U.S., the majority of these written by the director and his assistant director of the department, John A. Ryan and Raymond McGowan, respectively. Particular among these was the "Social Action

\footnotetext{
2 "Brief Historical Review of the Inception of the Work and Its Aims," ACUA/USCCB SAD Papers, Box 1, Folder 4,1 . ${ }^{3}$ Ibid., 9.
} 
Series," which in a similar manner as the press releases, applied the core concepts of Pius XI's Quadragesimo Anno to the current economic trends and proposals being discussed by the nation and its business and labor community. ${ }^{4}$

The Department also took a more hands-on approach to its educational efforts, instituting study clubs for the laity and the clergy, as well as lecture circuits and the like, but it was the Catholic Conference on Industrial Problems which highlighted these efforts. Raymond McGowan developed the CCIP in December of 1922, establishing an organization which set up yearly conferences meant to disseminate Catholic social principles so that its attendees might apply them to American industry. While doing so, it never sought to take stands or define its positions on such matters as strikes, wage law requirements, or on the appropriateness of labor injunctions, but rather sought to study and discuss these problems. Consequently, as a part of its constitution, the CCIP forbade any voting on matters of industrial policy. ${ }^{5}$ In this manner the CCIP presented a safe environment for the industrialists in attendance; instead of confronting employers through policy votes, the CCIP hoped to influence them by providing an environment where they might learn more about their employees' views, as well as the Catholic social teaching which supported them. The end result was that the CCIP hoped to promote labor cooperation instead of labor conflict, and it structured its meetings in such a way as to support this goal. Each meeting of the CCIP focused on a particular social topic - most often collective bargaining or the living wage - which was presented by three different speakers, each representing the employer, the employee, and Catholic social teaching respectively. By doing so, the SAD and its management forced representatives of both labor and industry "to realize that

\footnotetext{
${ }^{4}$ William James Lee, "The Work in Industrial Relations of the Social Action Department of the National Catholic Welfare Conference 1933 - 1945" (PhD diss., Catholic University of America, 1946), 52.

${ }^{5}$ Ibid., 5.
} 
they belong to the same Church, that the Church has a common social creed for both, and the difference of views concerning the application of this social creed to particular problems are capable of a greater degree of reconciliation than they had been accustomed to think.",6

Besides these educational endeavors, the SAD also sponsored international bodies to promote Catholic social action and justice, those being the Catholic Association for International Peace [CAIP] and the Inter-American Catholic Social Action Confederation [IACSAC]. While these two organizations should be considered as separate from the SAD, they still owed very much in terms of development and structure to the department. Staff members of the SAD regularly worked with both organizations, and maintained constant ties throughout the department's history.

The Catholic Association for International Peace organized itself immediately following the Eucharistic Congress of Chicago, June of 1926, culminating in its formation during a two day conference in Washington, D.C, April $20^{\text {th }}$ and $21^{\text {st }}, 1927$. The CAIP sought to "study, disseminate, and apply the principles of natural law and Christian charity to international problems of the day," and to "consider the moral and legal aspects of any action" that could have been proposed in the international arena. These findings were then published in Catholic and secular presses in order to promote international peace and social harmony. ${ }^{7}$ Besides this work, the CAIP also promoted "the formation of conferences, lectures and study circles with the view of educating Catholic opinion upon the subjects relating to international morality and of acquainting, as far as possible, the general public with the Church's teachings upon these

\footnotetext{
${ }^{6}$ John A. Ryan, "The Catholic Conference on Industrial Problems," Catholic Action XXI (October, 1939$)$ : 9.

7 The Catholic Association for International Peace Membership Pamphlet, ACUA/USCCB SAD Papers, Box 43 Folder 3.
} 
matters." ${ }^{\prime 8}$ Its original membership consisted of the Catholic men and women represented by the National Council of Catholic Men, the National Council of Catholic Women, and the Social Action Department of the NCWC, who called for the creation of such an organization immediately following the Eucharistic Congress. ${ }^{9}$

The officers of the CAIP were elected every year at its annual meeting, and served as the executive committee consisting of a president, eight vice-presidents, a treasurer, and a secretary. Besides this executive committee, there was a membership committee of five selected by the president. The main contribution from the association was its annual reports, which were forwarded to all Catholic organizations, so that they could be informed of international events "free from partisan prejudice," reliant upon "the accuracy of the facts and the soundness of the judgments which" the CAIP presented. ${ }^{10}$ These reports were published by the executive committee in "the American tradition of political democracy under which citizens have the right and the duty to join in the general formation of foreign policy," but at the same time guided by "the Catholic tradition of justice, charity and peace to all mankind." Consequently, the CAIP sought to influence the international policies of the United States by informing Catholics of those policies and how they related to Catholic teachings on peace and justice.

The IACSAC formed in August of 1948, two years after Higgins joined the SAD. ${ }^{11}$ Describing itself as a "federation of national and international organizations in the Americas that work for the social and economic welfare of the peoples of the Americas and the peoples of the

\footnotetext{
8 "Memorandum on the Formation of the Catholic Association for National Peace," ACUA/USCCB SAD Papers, Box 43, Folder 1.

9 "Genesis of the Accompanying Constitution," ACUA/USCCB SAD Papers, Box 43, Folder 4.

${ }^{10}$ The Catholic Association for International Peace Membership Pamphlet, ACUA/USCCB SAD Papers, Box 43 Folder 1.

${ }^{11}$ Raymond McGowan served on the IACSAC's Board of Directors, serving an integral role in forming its constitution, as well as its application and eventual membership to the Pan American Union.
} 
world... according to the principles of the social teaching of the Church," the organization sought to foster social justice within the Americas. ${ }^{12}$ Its original membership consisted of the Catholic social action secretariats, as well as those organizations which fulfilled a similar role where no secretariat yet existed, of the following countries: Argentina, the Bahamas, Bolivia, Brazil, British Guiana (now known as Guyana), British Honduras, Canada, Colombia, Cuba, the Dominican Republic, Ecuador, El Salvador, Haiti, Honduras, Guadalupe, Guatemala, Mexico, Nicaragua, Paraguay, Peru, Trinidad, and the United States. ${ }^{13}$ Each secretariat, or its organizational equivalent, was represented by membership in an Executive Council which consisted of two persons per international organization, one selected by vote and the other appointed by the secretariat they represented. The interests of the IACSAC focused particularly on labor and industry, social legislation, rural life, international economic relations, and social work.

At its first initial meeting in Rio de Janeiro in 1948, the aims of the conference became clear. It advocated principles similar to those found in the encyclical Quadragesimo Anno, particularly that of its Industry Council Plan. Pope Pius XI's Industry Council Plan called for economic planning "based on the industries and professions themselves, freely organized and fully functioning," which could only be realized by "an adequate system of organized industries and professions... [based on] a council of organized employers and labor unions of every industry, with similar councils in agriculture and the professions, relying on governmental

\footnotetext{
${ }^{12}$ IACSAC, "Constitution of the Inter-American Catholic Social Action Confederation," ACUA/USCCB SAD Papers, Box 5, Folder 62.

${ }^{13}$ John F. Parr to Secretary General of Pan American Union, October, 29, 1948, ACUA/USCCB SAD Papers, Box 5 Folder 58, 1.
} 
assistance enabling them to function well, but never being under governmental domination." 14 Thus, in many aspects the IACSAC sought to implement the same goals and work towards the same ends as the SAD in the United States, but on an international level.

These three organizations - the CCIP, CAIP, and IACSAC - defined Higgins's work and focus while serving as the Assistant Director, and later as the Director, of the SAD. Each was a major component of the department, particularly in its international goals. However, these were not the only concerns of Higgins during his time at the department.

\section{Higgins's Role at the SAD}

The financial state of the Social Action Department upon Higgins' arrival was not encouraging. Consisting of a staff of ten, the department managed a monthly budget of $\$ 2001.00$, and regularly faced deficits throughout its life as an organization. Its financial well-being was largely dependent upon the contributions of its clerical staff, among them being Higgins, who in order to save funds, refused to use their expense accounts. If they had, the department "would have been in the hole," which from McGowan's perspective meant that the priests of the SAD effectively "subsidized the Department out of their salaries." ${ }^{15}$ As it stood, McGowan felt that the situation was "no way for a Department or Bureau to operate," and described such a financial situation as impossible. ${ }^{16}$ Time would prove this a constant struggle for the department, as it

\footnotetext{
${ }^{14}$ IACSAC, "Resolutions Adopted by the Conference Rio De Janeiro, 1948," ACUA/USCCB SAD Papers, Box 5, Folder 60; note that greater discussion of the Industry Council Plan and its implementation by the SAD is discussed later in this chapter.

${ }^{15}$ Social Action Department of the National Catholic Welfare Conference, "Monthly Budget of Social Action Department: 1944-1945," ACUA/USCCB SAD Papers, Box 65, Folder 1, 1.

${ }^{16}$ Ibid., 2.
} 
continually met shrinking budgets, leading to a loss of staff throughout its years as an organization.

When Higgins first joined the SAD, he replaced Father John Hayes, who had moved to drier climate of Texas in an effort to alleviate the symptoms of his tuberculosis. As was mentioned in the chapter's opening, with Ryan' death McGowan became the director, and so Higgins, who had only expected his time at the SAD to be temporary in nature, soon found a more permanent position as the Assistant Director to McGowan. Shortly following Higgins appointment, Fr. John F. Cronin joined the department. Cronin, a Sulpician priest who hailed from Glen Falls, New York, had also received a degree from the Catholic University of America. Following his work there, Archbishop Edward Mooney of Detroit, who was then serving as the chairman of the NCWC, enjoined him to investigate Communist infiltration of American labor unions, which he later submitted to the NCWC under the title, "The Problem of American Communism in 1945: Facts and Recommendations." The report was so well received that Cronin was also named as an Assistant Director to McGowan. His understood role within the department was to focus on and combat communism as a force within the American labor movement. $^{17}$

This effectively divided the assistant directorship during McGowan's tenure as director, allowing both Higgins and Cronin to pursue their own areas of interest. For Cronin, this meant an ongoing battle with communism, while Higgins focused on labor-relations and social justice. Cronin's work was particularly beneficial to the department, since it deflected charges of socialism and communism, which allowed Higgins and McGowan to conduct their own work

\footnotetext{
${ }^{17}$ Stephen M. Koeth, CSC., "The Strength and Limits of American Catholic Confidence: Reverend John F. Cronin, S.S., and His Political Friendship with Richard M. Nixon, 1947 - 1960," Journal of Church and State, Advance Access Article, March 26, 2013 (online publication only); "U.S. Cardinal Mooney Dies," The Washington Post and Times Herald, October 26, 1958.
} 
more freely. The remaining members of staff consisted of Ms. Linna E. Brisette, who served as the department's field representative, as well as that of the CCIP; Ms. Margaret Carrity, Interracial Secretary of the CCIP; Ms. Rita Schaefer, Committee Secretary of the CAIP; and Ms. Kathleen McCann, Office Manager and Youth Program Consultant. Soon after Higgins joined, Ms. Alma Jane Hale, Ms. Marjorie Malay, Ms. Mary Pollock, and Ms. Patricia Kelly joined the department as secretaries for the aforementioned staff.

As Assistant Director to McGowan, Higgins served a multitude of tasks relevant to the field of social justice and action: lecturing on social issues to the attendees of the CCIP conferences; writing speeches and serving as an advisor for those archbishops and bishops speaking on social issues; contributing to the IACSAC as an executive member, as well as moderating lectures for the CAIP; and building contacts with industrial leaders, primarily those in labor unions. Certainly, these demands kept Higgins busy during his time as Assistant Director, but his main labors concerned two publications tied to the SAD - Social Action Notes for Priests and The Yardstick.

Higgins’ predecessor, Rev. John M. Hayes, began Social Action Notes for Priests in December of 1940 as a news pamphlet for diocesan priests who sought to implement the Church's social program. Serving as a monthly bulletin, the Notes reached approximately 1800 priests by the time Higgins took over the venture. The Notes updated priests on current events in the social field, what their colleagues were accomplishing as priests devoted to social action, and provided suggestions for similar ventures. Higgins' own contribution bolstered the Notes by including a review of social action literature. Ultimately, the bulletin hoped to educate, instruct, and encourage priests in the field of social action, particularly that of labor relations. Higgins, in his annual report of the SAD to the Administrative Board of the NCWC made this quite clear, 
stating that the "principal value of the Notes is to stimulate interest among the priests of the country and to encourage them by a monthly reminder of the examples of others to undertake programs of Catholic social action in their own area." 18

Besides instructing the nation's priests on social action, Social Action Notes for priests also provided the SAD with a "catalogue of priests who have a special interest in the field of Catholic Social Action." 19 According to Higgins, this was significant because the names of these priests were only added by direct request, demonstrating a true devotion to the social cause among its subscribers. These direct requests also promoted correspondence between interested priests and the staff of the SAD, which informed the department of "all current developments in the field" of social action. Thus, the Notes created a network by which the SAD could keep abreast of the social life and action of the American church, while at the same time informing them of the secular events which required action by the department. Furthermore, the Notes enabled the department to guide priests in their social work, and offer them support through the NCWC News Service, effectively promoting their cause through the Catholic press. ${ }^{20}$ The service continually grew in popularity during Higgins term as Assistant Director, reaching a membership of 4000 priests just prior to his promotion to Director of the department. ${ }^{21}$ This encouraged the department in its work in the field of social action, as it saw more and more priests joining the cause.

Higgins began writing for The Yardstick in January of 1945, declaring in his first column that racial prejudice hindered war production, and the lack of employment of African-Americans

\footnotetext{
${ }^{18}$ George G. Higgins, “Annual Report: Father Higgins,” ACUA/USCCB SAD Papers, Box 1, Folder 66, 1. ${ }^{19}$ Ibid.

20 "Higgins Annual Report," ACUA/USCCB SAD Papers, Box 1, Folder 71, 1 -2.

${ }^{21}$ National Catholic Welfare Conference, "Annual Report of the Department of Social Action, Washington, D.C., 1955," ACUA, Reading Room Stacks, 5.
} 
in industry constituted a "serious blot on our Patriotism.,"22 By 1946 Higgins had assumed its duties full time, taking over for McGowan in that function. The Yardstick was a weekly column, normally consisting of 750 words, devoting itself to some form of the social apostolate. More often than not, Higgins used the column to address labor-management issues of the day, such as the passage of the Taft-Hartley Act; the dangers of the closed-shop legislation being promoted on the state level; and various strikes of the day, like the steel industry strike of 1959. The Yardstick remained an important aspect of Higgins' work throughout his years in the social apostolate, only ceasing its publication on May 1, 2002, a year prior to his death in 2003.

By seeking to measure "reform proposals against the 'yardstick' of papal teachings" The Yardstick was particularly important as an unofficial voice of the SAD. ${ }^{23}$ Throughout Higgins' time writing the column, it provided him - and through him, the department - a voice on social issues and industrial management. And while these social issues were varied, more often than not, Higgins related these events back to the social encyclicals Rerum Novarum and Quadragesimo Anno. Such an effort is not surprising, however, for the tenets of Rerum Novarum and Quadragesimo Anno stood first and foremost among the guiding principles of the department, as well as that of the Bishops' Program of Reconstruction and their Pastoral Letter of 1919.

\section{Guiding Principles of the SAD}

As has been mentioned in the introduction, the basis for the SAD's work in social teaching lay with the two great social encyclicals of the day, Rerum Novarum and Quadragesimo

\footnotetext{
${ }^{22}$ George G. Higgins, "We Can No Longer Tolerate Discrimination," The Yardstick, Jan. 8, 1945, ACUA/GGH Papers, Box 343, Folder 5.

${ }^{23}$ Gerald M. Costello, Without Fear or Favor: George Higgins on the Record (Mystic: Twenty-Third Publications, 1984), 19.
} 
Anno, as well as the Bishops' Program of Social Reconstruction and the Bishops' Pastoral Letter of 1919. Rerum Novarum, published in 1891 under the auspices of Pope Leo XIII, was the first major social encyclical of the Catholic Church, addressing such issues as the place of property in the social order, the place of the state and its role in society, and the proper relationship between labor and capital. The Bishops' Program of Social Reconstruction and their Pastoral Letter in 1919 focused heavily on the right to a living wage, the worker's right to organize, and a call for joint management between capital and labor over industry. Finally, Quadragesimo Anno celebrated the fortieth anniversary of Rerum Novarum by reapplying its principles to the new world order that had developed since its predecessor's publication. Being the most recent encyclical preceding Higgins' tenure at the SAD, it undoubtedly had the greatest influence throughout his work as assistant director.

Quadragesimo Anno built upon Rerum Novarum, and more importantly for Higgins and the SAD, established the principle of subsidiarity. Quoting passages from both encyclicals, Higgins would state in 1952 that "Rerum Novarum... was important principally as the precursor of Quadragesimo Anno;" the “"idols of liberalism” had to be overturned before the more positive and more fully developed program of 'reconstructing social order' and 'perfecting it in conformity with the law of the Gospel' could be successfully launched." ${ }^{24}$ First and foremost, this meant Rerum Novarum established the Church's right to address social and economic problems, "in so far as these "have a hearing upon moral conduct." ${ }^{, 25}$ And in so far as labor and industry were concerned, most issues did have such a "hearing" in the concern of the Church.

\footnotetext{
${ }^{24}$ George G. Higgins, "1952 Catholic University of America Workshop Talk” (talk presented at the Catholic University of America, Washington, D.C., 1952), ACUA/GGH Papers, Box 323, Folder 10, 3.

25 "Brief Historical Review of the Inception of the Work and Its Aims," ACUA/USCCB SAD Papers, Box 1, Folder 4, 21.
} 
Rerum Novarum defined the family as the basis of society, of which the state has an obligation to protect. The role of the state was to insure the welfare of all its citizens, which meant the state had to guarantee an individual's rights. Besides this role, the state had to foster an environment which promoted the development of the self, of which the foundation of a family and the security of employment were essential. This type of environment served as the basis for human dignity, which was essential if the state was to fulfill its duty of promoting the welfare of its populace. ${ }^{26}$ This did not mean that the state should regulate all life, however, particularly that of private property. Private property was defined as an inviolable right of man, and the lawful result of his or her labors, and so defined an individual's dignity. ${ }^{27}$ It was for this very reason that Leo XIII supported the right of workers to strike and organize, and argued against the principle of "free consent" in economic life, whereby those who accepted sub-standard wages knowingly accepted the inadequacies of their employment as part of the contract. According to this mentality, free consent made such contracts ethical. Instead, Rerum Novarum argued that such a system refused to acknowledge that an individual's dignity was tied to his or her labors. ${ }^{28}$ It was for this reason the encyclical recognized that any employment contract exists between two persons - and thus was subject to social justice and the church's judgment. Furthermore, it was also for that reason that workers - as well as employers - had the right to form mutual organizations that would serve to represent the individual worker, and protect his or her dignity by negotiating contracts on their behalf.

Echoing the principles of Rerum Novarum, the National Catholic War Council published the Bishops' Program of Social Reconstruction on February 12, 1919. Written by the first

\footnotetext{
${ }^{26}$ William Murphy, "Rerum Novarum," in A Century of Catholic Social Thought: Essays on 'Rerum Novarum' and Nine Other Key Documents, ed. George Weigel and Robert Royal (Lanham: University Press of America, 1991), 18. ${ }^{27}$ Ibid., 13.

${ }^{28}$ Ibid., 20.
} 
director of the Social Action Department, John A. Ryan, the bishops did not actually seek to set up an official program of reconstruction, asserting that such "an undertaking would be a waste of time as regards immediate needs and purposes" of the nation, and that "no group or section of the American people.... is ready to consider a program of this magnitude."29 Such was not to say, however, that the nation did not need to address certain concerns following the First World War. Realizing that the country's servicemen and women were returning from the war, the bishops believed that the industrial state of the country needed reassessment, especially with the continued presence of industrial conditions which they believed led to the conflict. The bishops found three major defects: "Enormous inefficiency and waste in production of commodities; insufficient incomes for the great majority of wage earners, and unnecessarily large incomes for a small minority of privileged capitalists. ${ }^{, 30}$ Consequently, the bishops proposed a series of obtainable reforms which supported men and women's right to a living wage, and which respected his or her human dignity.

As part of their plan, the bishops called upon Congress' continued support of the United States Employment Service, which was a necessary organization to reintegrate servicemen of the war into the work force. This was not the only wartime organization it supported either, as the bishops called for the continuance of the National War Labor Board, which in their eyes had supported a "family living wage for all male adult laborers; recognition of the right of labor to organize and to deal with employers through its chosen representatives; and no coercion of nonunion laborers by members of the union." ${ }^{31}$ Besides this, the bishops requested that wage rates remain at their current levels, since these rates had finally risen to that of a living wage - a

\footnotetext{
${ }^{29}$ Our Bishops Speak: National Pastorals and Annual Statements of the Hierarchy of the United States (Milwaukee: Bruce Publishing Company, 1952), 248.

${ }^{30}$ Ibid., 257.

${ }^{31}$ Ibid., $250-251$.
} 
wage which the bishops considered as the bare minimum of social justice. The bishops also called for a legal minimum wage based upon these same precepts - that being a wage which would support a family through the support of a single worker. Along these same lines, the bishops advocated government action to reduce the cost of living by "abolish[ing] monopolistic extortion" in the marketplace, and the creation of co-operative stores to reduce living costs directly through consumer costs reduction. Finally, the bishops called for greater representation of the worker in industrial management, which they understood as the "control of processes and machinery; nature of product; engagement and dismissal of employees; hours of work, rates of pay, bonuses, etc.; welfare work; shop discipline; relations with trade unions." 32

The War Council's efforts towards social reconstruction did not stand alone, for a few short months later the united body of bishops addressed and expanded upon many of the same issues in their Pastoral Letter of 1919, published after the first annual meeting of the hierarchy on September $26^{\text {th }}$. Issued by the National Catholic Welfare Council, the pastoral letter served to warn the members of American Catholic faithful that America faced grave problems. These problems threatened to "undo both our recent achievement and all that America ... [had] so far accomplished" in ending the "unequal distribution of wealth, power, and worldly advantage." 33 It was the dangers of such a materialistic world which served to ruin it - those of "materialism, of atheism, and of other doctrines that banish God from His world, degrade man to the level of the brute, and reduce the moral order to a struggle for existence." ${ }^{34}$ From the bishops' point of view, it was such issues of discontent and struggle which caused men to rebel. Fortunately, the person

\footnotetext{
${ }^{32}$ Ibid., 255.

${ }^{33}$ Ibid., 30.

${ }^{34}$ Ibid., 33.
} 
of Christ served as the answer to these dilemmas, for in "“"His person was shown the excellence and true dignity of human nature, wherein human rights have their center."35

Harking back to Rerum Novarum, the bishops argued that the state existed to "protect the divinely established rights of the individual and of the family." ${ }^{36}$ In order to protect the rights of the individual and the family, the bishops asserted that the rights of the community had to be acknowledged in the industrial conflict, not just those of labor and capital. And since most industrial conflicts affected the community at large, often by hindering the goods and services essential to daily life, the rights of the community had to come first. In this sense, no claims against the common good were valid. Bound together by their need for each other, it was essential that capital and labor recognized the inherent dignity of humanity - much in the same way the Church believed that Christ was as much human as he was divine. In this light, labor was an essential part of one's dignity and personhood, and it was "shameful and inhuman to treat men like chattels, as a means for making money, or as machines for grinding out work." The recognition of human dignity was not merely a social issue however, for it was also beneficial to economic progress as well. If management treated "the laborer first of all as a man," then such treatment would "make him a better workingman; by respecting his own moral dignity as a man," the worker would "compel the respect of his employer and of the community." 37 Thus, the Church promoted class harmony in opposition to class conflict, and supported the right of workers to organize, as well as the right of employers' to demand that these organizations honor the contracts and agreements made with them. When negotiating and honoring such contracts failed, the bishops supported arbitration as the best means to resolve these conflicts.

\footnotetext{
${ }^{35}$ Ibid., 32.

${ }^{36}$ Ibid., 37.

${ }^{37}$ Ibid., 49.
} 
Furthermore, the bishops continued to support a living wage, and a system of industrial management that included worker contributions. By doing so, the dignity of the worker would have been recognized, lessening class conflict.

Published on May 15, 1931, forty years after Rerum Novarum, Quadragesimo Anno served as the capstone to these three documents. The main purpose of the encyclical was to reassert the principles of Rerum Novarum, but applied to the current industrial age of the 1930s especially in light of the detrimental effects which led to the Great Depression. Many within the SAD interpreted the encyclical as a justification for their work in the field of social justice, particularly those reforms advocated by John A. Ryan, who had penned The Bishops' Program of Social Reconstruction of 1919. Of primary importance to the SAD was its definition of private ownership - particularly in its application towards the department's call for joint control of industry - which according to the encyclical contained a "twofold character ... individual and social." "38 There was a "distinction between the rights of ownership in the proper use of materials goods," and it was the function of government to "detail the limits, both of its rights and use." Accordingly, both labor and capital had "a right to share in the joint product of industry," of which in "the past an excessive share was claimed by capital." 39 This share in the joint product of industry would have been best expressed through some form of joint ownership, or at least some share in the management of profits, a principle the SAD had argued for some time.

And while the state had the responsibility to "detail the limits" of ownership, the encyclical also asserted that the state did not have the power to solve the social question, even

\footnotetext{
${ }^{38}$ Pope Pius XI, “Quadragesimo Anno: Encyclical of Pope Pius XI on Reconstruction of the Social Order,” The Vatican, http://www.vatican.va/holy_father/pius_xi/encyclicals/documents/hf_p-xi_enc_19310515_quadragesimoanno_en.html (accessed 10.16. 2013).

39 "Brief Historical Review of the Inception of the Work and Its Aims," ACUA/USCCB SAD Papers, Box 1, Folder 4, 28 .
} 
with the multitude of legislative tools at its disposal. The answer to the social question lay in the power of the organizational bodies of industry itself - be it both capital and labor. The encyclical advocated the principle of subsidiarity, which demanded that the state, or for that matter any association, existed for the citizen and his or her self-realization. Consequently, it was "gravely wrong to take from individuals what they can accomplish by their own initiative and industry," and to assign those labors to the larger associations. In the same manner, it was also "an injustice and at the same time a grave evil and disturbance of right order to assign to a greater and higher association what lesser and subordinate organizations can do." ${ }^{, 40}$ The reasoning behind this charge was that the human person was seen as an inherently social being, which could only attain self-realization through social relationships. Consequently, the purpose of the state, or that of any association or community, was to help individuals in the pursuit of these relationships insofar as they helped the individual achieve self-realization. ${ }^{41}$

Neither was the principle of subsidiarity limited to the individual, for the encyclical applied this principle to larger organizational bodies under the auspices of "solidarism," which may be best understood as the application of subsidiarity principles to the economic order. ${ }^{42}$ As a principle, solidarism rejected the tenets of socialism and laissez faire capitalism. Instead, it proposed a federation of businesses, professions, and occupations all working together to guide the nation's economy. Guided by the principles of subsidiarity, these organizations would represent individuals in relation to the state, while at the same time being largely autonomous from the state itself. The state's responsibility would be to cooperate with these federated

\footnotetext{
${ }^{40}$ Pope Pius XI, “Quadragesimo Anno: Encyclical of Pope Pius XI on Reconstruction of the Social Order," The Vatican, http://www.vatican.va/holy_father/pius_xi/encyclicals/documents/hf_p-xi_enc_19310515_quadragesimoanno_en.html (accessed 10.16.2013).

${ }^{41}$ Thomas C. Kohler, "Quadragesimo Anno," in A Century of Catholic Social Thought: Essays on 'Rerum Novarum' and Nine Other Key Documents, ed. George Weigel and Robert Royal (Lanham: University Press of America, 1991), 31.

${ }^{42}$ Ibid., 33.
} 
entities, but only insofar as the common good required it. Consequently, the encyclical's promotion of solidarism proposed a system whereby labor, management, and government cooperated with one another, all the while respecting each other's autonomy and jointly guiding the economy for the welfare of the common good. ${ }^{43}$ In this sense the principle of subsidiarity was not limited to individual relations, but also existed as a principle which could be applied to institutions of all types. By promoting such a system, the state respected the individual's right to govern one's self, which the Church considered an inherent element of social justice. ${ }^{44}$

It was for this reason that not only did Quadragesimo Anno support unions and collective bargaining, as the Church did with Rerum Novarum, but that it defined them in relation to the state and its place within the bargaining process. Collective bargaining was seen as much more than the method for setting rates and wages between labor and management, but also as a form of private legislation between the two. By encouraging such a system, the state recognized the efforts of economic associations towards self-governance, especially since the parties involved in the collective bargaining process regulated and administered their agreements amongst themselves. This could even take the form of private adjudication, whereby both parties arbitrated outside the state's legal system, and thus keep the state removed from their affairs. ${ }^{45}$ This type of self-government could only be seen as beneficial to the state, since the state could then focus its time and resources in other areas of a greater and more vital interest.

Quadragesimo Anno argued that such a system had already once existed in society in the form of medieval guilds, but, that individualism, i.e. laissez faire capitalism, had disrupted and nearly destroyed the "rich social life which was once highly developed through associations of

\footnotetext{
${ }^{43}$ Ibid., $32-33$.

${ }^{44}$ Ibid., 38.

${ }^{45}$ Ibid., 40.
} 
various kinds," and had left a society composed "virtually only [of] individuals and the State." This was of great harm to the state itself, since "with such a structure of social governance lost, and with the taking over of all the burdens which the wrecked associations bore," the state had "been overwhelmed and crushed by almost infinite tasks and duties." 46 Consequently, the encyclical advocated a return to the social structures that had been promoted in the medieval guild system, but in a modernized form of industry councils based on subsidiarity principles. In this regard, McGowan and the Social Action Department hoped to fulfill Pope Pius XI's wish.

\section{Agenda of the SAD: Implementation of Quadragesimo Anno}

Within four years of Higgins joining the SAD, McGowan had initiated an agenda to reform society according to the principles of Quadragesimo Anno. Evidence of this may be seen in two separate documents: the departmental file labeled "Industry Councils," dated May 10, 1949, and McGowan's “Outline of the Social Order of the Encyclicals," written on Oct. 12, 1950. In relation to one another, "Industry Councils" discussed the origins of the term "Industry Council Plan" in length, while McGowan's outline detailed what he considered to be the social order demanded by the social encyclicals. These two documents portray the agenda McGowan hoped to institute, which if accomplished would radically alter the economic landscape of the United States by integrating Catholic principles with economic practice. ${ }^{47}$

\footnotetext{
${ }^{46}$ Pope Pius XI, “Quadragesimo Anno: Encyclical of Pope Pius XI on Reconstruction of the Social Order," The Vatican, http://www.vatican.va/holy_father/pius_xi/encyclicals/documents/hf_p-xi_enc_19310515_quadragesimoanno_en.html (accessed 10.16. 2013).

${ }^{47}$ As evidenced by the IACSAC's constitution mentioned earlier in the chapter, it appears that McGowan did not limit his goal of instituting the Industry Council Plan solely to the United States. Acting on the Board of Directors for the IACSAC, one may assume that McGowan exerted his influence to make this agenda international in scope, but more research is needed to support this claim.
} 
. Ironically, the actual term "Industry Council Plan" served as the first major obstacle to instituting the department's agenda to reconstruct American economic life. Adopted by the Catholic Sociological Society to describe the new social order, it had also been used by the Administrative Board of the NCWC in its November, 1948 statement, "On the Christian in Action." Unfortunately, those within the department did not enthusiastically support the term since it put "emphasis on industry" alone, which made it "inapplicable to other professions," especially that of agriculture. This notwithstanding, the department considered "the poverty of the English language" as the major defect facing their task of instituting such an agenda, since there was no way to "translate clearly and precisely the words of Quadragesimo Anno," especially the terms "ordines," "collegia seu corpora," and "corps professionelle" that had appeared in the department's translations of the document. ${ }^{48}$

It was this defect which had delayed implementation of the encyclical on a societal level since its inception in 1931. Noting that previous interpreters of the encyclical used the terms “ordines," "collegia seu corpora," and "corps professionelle" interchangeably, prior translations had simply resorted to describing each of these terms as "vocational groups'. Complicating matters, the term corps professionelle had later been translated as 'occupational groups'. The term "collegia seu corpora" also proved difficult as most translations used the term 'guilds' in its place, but the "term guild had lost its primary meaning in English and... [had] an almost archaic flavor when used in its primary sense." Unfortunately, these definitions lacked both clarity and proper meaning, which stirred controversy over the intent of the encyclical, as well as the scope

\footnotetext{
${ }^{48}$ Social Action Department of the National Catholic Welfare Conference, "Industry Councils," May 10, 1949, ACUA/USCCB SAD Papers, Box 13, Folder 26, 1; Given the terms discussed here are in French, it appears that the SAD was using a French translation of Quadragesimo Anno when it first considered the encyclical. The "Industry Council" document never addresses the French origin of these terms.
} 
of its implementation. ${ }^{49}$ Consequently, these misunderstanding had hindered the encyclical's application in the United States.

In the years that followed, many different expressions of the social order were bandied about, such as conferences of industry, guilds of industry, economic democracy, and industrial democracy, to name a few. It was not until 1947 that a final term gained some traction, that being the term "Industry Council Plan," which had been defined by the American Catholic Sociological Society. Those within the SAD felt that such a term was adequate, but still left much in way of desire for a proper English translation. Regardless, this was the term used by McGowan in his Oct. 12, 1950 presentation advocating the reconstruction of the social order by way of Quadragesimo Anno.

In his "Outline of the Social Order of the Encyclicals," McGowan set about defining social justice, the social order the encyclical promoted, and how to promote the methods necessary to bring about such societal change. In the document, McGowan acknowledged Pius XI's definition of social justice as the "obligation of everyone to do everything necessary for the common good," but thought this definition too limited in its approach. McGowan instead defined it rather as "the virtue that obliges everyone to organize each industry and profession, and federate all industries and professions, and use that system and use government to get everything done that is necessary for the common good, the good of groups and the good of individuals. ${ }^{, 50}$ It was this federation of organized industries and professions which represented the social order as described in the encyclical, that being the "ordo socialis collegiorum seu

\footnotetext{
${ }^{49}$ The author of the document argues that the interpretation of an unnamed, yet "well-renowned priest" served as the best example of the confusion these terms had generated. This "well-renowned priest" had argued "that occupational groups meant ... not the building of industry but only carpenters," which in turn led to his arguing that the encyclical "condemned all labor unions except craft unions" (Ibid., 4).

${ }^{50}$ Raymond McGowan, "Outline of the Social Order of the Encyclicals," Oct. 12, 1950, ACUA/USCCB SAD Papers, Box 13, Folder 23, 2.
} 
corporum vel consortium 'ordinum'," and for which McGowan substituted the term "Industry Council Plan" as a suitable synonym. ${ }^{51}$

In order to be fully realized, such a society would require that all of its peoples organize so that they could perform social charity more effectively. Social charity, as defined by McGowan, was "the virtue of motivating people to work together for the common good because of their recognition of their dependence on one another under God." It was the role of the Church to "train its members in [these] Catholic principles and their application... so as to help put them into effect." ${ }^{52}$ Such a social order could not conceivably be realized instantaneously either, but would require an evolution of the current social structure. The primary reason for this was that there remained "the remnants of Individualism that acts apart from the moral law" within society, as well as the public's inclination to rely "too much [on the] government for aid because of the weakness of private organizations." Unfortunately, these conditions had encouraged an “excessive growth of government," and had fostered a class-struggle type of collective bargaining, which worked against the realization of social reconstruction. ${ }^{53}$

This was not to say that collective bargaining was not a part of establishing the new social order however. Rather, McGowan's interpretation of the encyclical called for the new society to "step beyond" traditional collective bargaining as they knew it. Rather than promoting collective bargaining solely on a per company basis, McGowan argued the encyclical promoted collective bargaining on an industry-wide scale as well. ${ }^{54}$ Such an adoption would require labor and management of industry to plan together, since any number of economic situations could

\footnotetext{
51 Ibid., 1.

52 Ibid., 2.

53 Ibid.

${ }^{54}$ McGowan makes clear in the document that company-wide collective bargaining serves a purpose in the establishment of the new social order, and that it should be interpreted as a step in the right direction.
} 
prevent fair wages, such as "poor or indifferent management, lack of using new technical methods, unjust burdens... and excessively low prices." In these instances, management and labor, together with government's assistance, could work together to overcome these circumstances for the benefit of the industry and the community which it served. In this sense, collective bargaining served as the impetus to leave behind the class-struggle elements of collective bargaining in favor of a form of class-cooperative bargaining.

Fortunately, the foundation for such a structure already existed within the United States, and the encyclical supported "a Social Order... built out of existing economic organizations." As McGowan understood it, this meant all the “employer's associations, labor unions, foremen's organizations, farmers-producers' cooperatives, bar associations, medical societies, etc.” which were already a force within the current economic system of the United States. ${ }^{55}$ An "Industry Council" then would comprise these organizations depending on the industry at hand, forming joint councils of owners' organizations and unions, farming cooperatives (dependent upon the types of crops grown), and organizations representing the various professions. These separate industry councils would come together in a federation of councils and work with the government to guide economic life for the common good. Such an arrangement would benefit all members, promoting "the common good of the people of each Industry and Profession, the common good of all Industries and Professions and the common good taken as a whole." ${ }^{56}$ Finally, the interests of these industry councils would naturally concern incomes, prices and quantity of output, since these issues concerned the common good and the dignity of man.

\footnotetext{
${ }^{55}$ Ibid., 6 .

${ }^{56}$ Ibid., 3 .
} 
The government "would retain all its ordinary powers and remain sovereign" in the face of such a system, and would in fact "be stronger and more effective in what it did," since the government "would have... to do less because the economic organizations [of the industry councils] would do more." ${ }^{57}$ To better facilitate this function and shared responsibility, it was the government's obligation to advance such a social order by guiding - and when necessary limiting - the nascent social order as it evolved, and once it became established. Above all, such government direction had to promote cooperation within industry rather than conflict. By doing so, the new social order would serve to prevent "excessive governmentalism," while at the same time ending the class struggle promoted under Marxist principles. ${ }^{58}$ Industry and labor would cooperate to guide economic and social life along with government, freeing government to focus on other concerns. Furthermore, such a system would mark the return towards the natural order of society, departing from the aspects of individualism which acted apart from the moral law. The new social order would be self-governing by nature, since it served the interest of the common good of the community. By serving the interest of the good of the community, it also served the common good of the individual, in that it promoted the self-realization of that person within the context of community, validating man and woman as a social being.

By Easter of 1951 the Social Action Department had already begun its promotion of such an economic system, necessitating a response by the hierarchy. The Administrative Board of the NCWC questioned the department's promotion of Pius XI's encyclical Quadragesimo Anno, particularly McGowan's interpretation of the Industry Council Plan it promoted. Questions by "some members of the Hierarchy" had arisen "concerning the attitudes and pronouncements of the Social Action Department on this subject," and some members of the hierarchy had even

\footnotetext{
${ }^{57}$ Ibid., 7.

${ }^{58}$ Ibid., 10.
} 
"raised objections that the officials of the Social Action Department... [had] misunderstood or exaggerated the rights and duties of the State in respect to the social and economic order as outlined in the Papal Encyclicals. ${ }^{, 59}$ As a direct consequence, the administrative board of the NCWC appointed Archbishop Patrick O’Boyle of Washington, D.C.; Archbishop Karl J. Alter of Cincinnati, Ohio; and Bishop John O'Hara of Buffalo, New York to act as an investigative committee, and to appoint a subcommittee of "Catholic leaders in the field of social action" to report to the board at a later date on the issue. ${ }^{60}$ Primary among its responsibilities was clearly to define the Industry Council Plan promoted therein, but also to define the duties of the State in such a system, as well as the role that capitalism would play in such a social order. ${ }^{61}$

In its report the committee acknowledged that Quadragesimo Anno did advocate "changes in the organic structure of economic society," and that the encyclical rejected the socioeconomic principles of "unrestrained competition, monopoly, dictatorship, and class conflict.” In order to change society for the better, it promoted "social and functional cooperation as a substitute for unrestrained competition" and the "promotion of the common good against class interest." 62 This did not mean the encyclical rejected capitalism whole cloth however, but rather

\footnotetext{
59 "Observations of the Episcopal Committee on the Report of the Social Order Committee," ACUA/GGH Papers, Box 189, Folder 8, 1.

${ }^{60}$ Archbishop Patrick O'Boyle had served as the director of Catholic Charities of New York prior to his appointment to the investigate committee, and would eventually serve as the Chancellor of the Catholic University of America. Archbishop Karl J. Alter soon became the vice-chairman of the NCWC, and would later serve as chairman. Bishop John O'Hara, who had served as the president of Notre Dame from 1934 to 1939, became the Archbishop of Philadelphia soon after his appointment to the investigative committee.

${ }^{61}$ The episcopal committee led by O'Boyle, O'Hara, and Alter recommended their reports remain confidential following its release, since there was neither clarity in the current reports of the Industry Council Plan, nor was there any unanimity by Catholic scholars as to the structure and function of such councils. Besides this, the investigative committee recommended that its reports be submitted to the "highest ecclesiastical authority" in order "to avoid any misunderstanding or misrepresentation of the teaching of the Church" on these issues (Ibid., 2).

${ }^{62}$ Ibid., 3.
} 
that capitalism which directed "economic activity according to its own will, scorning the dignity of workers, the social character of economic activity and the common good."63

The reform of such an unrestrained capitalism depended upon the State to institute such change, whose duty it was to "abolish class conflict and promote the cooperation of functional economic groups." It was the promotion of these "functional economic groups" that the committee recognized as the "Industry Council System." 64 The committee agreed that such a system called for economic councils composed of representatives from both management and labor, and that such councils be established for entire industries on the national level. ${ }^{65}$ How the State would interact with such a system was difficult to predict however, since the encyclical did not specifically endorse governmental representation, but simply described the role of the State "as 'directing, watching, urging, [and] restraining, as occasion requires and necessity demands. " $" 66$ Regardless, the bishops could not envision such a system without the power of the government to override their decisions, should they be contrary to the common good. Such a system was structured for the common good however, and in reality, its implementation would relieve the State of many of its duties, allowing it to focus on other matters.

In the end, the bishops felt that the Industry Council program would decide "such matters as are required by the common good of industry and the common good of all," but the "extent of such decisions and the range of interests likely to be embraced by the common good" were matters for scholars and other experts to discuss rather than the members of the committee. ${ }^{67}$ The main reason for this decision was that the committee recognized that Quadragesimo Anno had

\footnotetext{
${ }^{63}$ Ibid., 7.

${ }^{64}$ Ibid., 9.

${ }^{65}$ It should be noted that the committee still supported labor-management on the plant level, which it saw as the "best preparatory step" towards the institution of such a system.

${ }^{66}$ Ibid., 11.

${ }^{67}$ Ibid., 12.
} 
provided principles of action, but not "blueprints" or a structure of how such action should take place. Consequently, at that time the committee advised it was premature to "define the detailed application of [its] principles to American life."68 This reservation was fleeting, however. Within a year, the chairman of the Administrative Board of the NCWC, Archbishop Karl J. Alter of Cincinnati, Ohio, published an article covering the Industry Council Plan and the Church's support of it in the August, 1952 issue of the Review of Social Economy. ${ }^{69}$ The SAD's interpretation of the Industry Council Plan had the official backing of the bishops.

In the years that followed, McGowan and the Social Action Department sought to sketch the blueprints they felt were defined in Quadragesimo Anno, and examined the ways that they might apply to American economic life. The findings of the committee largely supported the social outline McGowan had created as director of the SAD, and helped resolve questions of the government's role in the Industry Council Plan. These questions would not end with the committee report either, for by shaping an industry council plan and promoting it, the department soon discovered the need to defend such a plan in the public arena.

Higgins, as McGowan's protégé, met this challenge in the pages of The Yardstick. As the author of The Yardstick, Higgins constantly applied the principles of Quadragesimo Anno -- and the Industry Plan the SAD felt it promoted -- to social issues of his day. This was no coincidence, as Higgins was only following the agenda that McGowan had instituted as director of the department. It was an agenda that remained the focal point of the department throughout McGowan's directorship, and one that Higgins continued after succeeding McGowan as director in 1954. Naturally, Higgins personalized its implementation in his own way, further defining the

\footnotetext{
${ }^{68}$ Ibid., 13.

${ }^{69}$ Karl J. Alter, “The Industry Council System and the Church's Program of Social Order,” Review of Social Economy 10 (August 1952): 97 - 107.
} 
role of the laity in the establishment of such a social order, as well as later incorporating the principles of two future encyclicals, Mater et Magistra and Pacem in Terris. It is in the following chapter that Higgins's role as Assistant Director is defined in relation to the department's attempt to bring about social change to American economic life through the economic principles of Quadragesimo Anno. 


\section{Chapter 3}

\section{Implementation of Quadragesimo Anno: The SAD's Response to the Taft-Hartley Act}

The point is simply this, that by concentrating on the legislative approach to labor-management problems, we are conveniently closing our eyes to the need for a more basic type of reform and reconstruction.

- Rev. George G. Higgins, The Yardstick, June 3, 1946

$\phi$

George Higgins was well-prepared upon his arrival at the Social Action Department in October of 1944, especially when it came to the Department's decision to implement Quadragesimo Anno's Industry Council Plan in America. When he joined the SAD, Higgins was writing his dissertation, "Voluntarism in Organized Labor in the U.S., 1930 - 1940," which he soon completed. As part of this work, he assessed the state of the two major unions in the United States, the AFL and the CIO, which were later to merge on December 5, $1955 .{ }^{1}$ Higgins understood the raison d'être of American unions, their history, and their ethos of "group individualism" as well as their influence on collective bargaining prior to the 1930s, which still existed in some form during the 1940s and 1950s. Consequently, Higgins knew the field on which the Industry Council Plan would play, and how to apply its principles to "a Social Order... built out of existing organizations" which included unions as well as management. ${ }^{2}$

\footnotetext{
${ }^{1}$ The Committee for Industrial Organization (CIO) formed on November 9, 1935, three weeks after the American Federation of Labor's (AFL) annual convention in Atlantic City, New Jersey. Consisting of former members of the AFL, its leadership broke with the AFL out of fear that it planned to place skilled industrial workers in craft unions, leaving unskilled workers at a disadvantage when arbitrating with management. Consequently, the CIO advocated granting charters to unions in industry without restriction, so that all industrial workers could be organized more quickly and united as a single force in collective bargaining efforts (Arthur J. Goldberg, AFL-CIO: Labor United (New York: McGraw-Hill Book Company, 1964), 31 - 35).

${ }^{2}$ Raymond McGowan, "Outline of the Social Order of the Encyclicals," Oct. 12, 1950, ACUA/USCCB SAD Papers, Box 13, Folder 23, 6.
} 
Higgins believed that, prior to the Great Depression of 1929, American unionism was defined by its voluntarism, meaning its reluctance to rely upon government aid and influence and its preference to achieve its goals through the power of its own economic strength. Consequently, unions interpreted most government action or legislation as a means to limit and restrict the objectives of American labor. This attitude changed with the advent of the Great Depression, however, as unions realized that by relying solely upon the economic bargaining strength of their members, their power was limited by the rise and fall of the national economy. Their influence upon management depended too much on the demand of their labor, for which there was little during the course of the Depression. Consequently, Higgins asserted that since the Great Depression of 1929, the union understanding of voluntarism was evolving. Instead of relying solely on economic strength to protect their interests, unions acknowledged that the government had to play some role in their relationship with management.

This change did not occur rapidly, nor did unions welcome government involvement with open arms. Citing the American Federation of Labor as a point of reference, Higgins argued that the union retained a "lack of confidence in all three branches of the Federal Government, legislative, executive, and judicial" following the Depression. ${ }^{3}$ Consequently, the AFL "had not clearly decided in its own mind on the role which Government should play in industrial life." Regardless, it was clear on one thing: that "unless Industry and Labor cooperated in some sort of democratic joint council, voluntarism was doomed, and the principles of voluntarism would go by default." ${ }^{, 4}$ Higgins argued that both the AFL and the CIO had learned the repercussions of relying solely upon their own economic strength in the market place, for with the fall of the

\footnotetext{
${ }^{3}$ George G. Higgins, "Voluntarism in Organized Labor in the U.S., 1930 - 1940" (PhD diss., Catholic University of America, 1944), 31.

${ }^{4}$ Ibid., 50.
} 
market in 1929 so too fell their own collective bargaining power. It was at this point, the beginning of the Great Depression and the years that followed, that unions came to realize that this form of voluntarism was a hindrance rather than an aid to achieving their goals. Simply put, the lack of demand for labor during this period led to a loss of strength for the unions. It was only with the intervention of the federal government and the passing of the National Industrial Recovery Act [NIRA] that unions began to regain some of that power, and their understanding of voluntarism began to evolve.

Passed in June of 1933, the NIRA attempted to secure the right of labor to organize without influence or coercion of management, and to protect the rights of union members to bargain collectively by representatives of their own choosing. For practical purposes, this meant an employee could not be forced to join a company union, or be prevented from joining an independent union. At the same time, the NIRA created specific industry labor boards managed by a central agency, the National Recovery Administration [NRA]. These boards of the NRA helped set standards of labor, including the maximum hours permitted in a work week, the minimum rates of pay, and any other aspects of employment deemed fit by the President in the forms of industry codes. The law also set up a National Labor Relations Board meant to mediate disagreements between unions and management. Unfortunately, the law did not fulfill its intended purpose, which was to secure the rights of labor and promote industrial peace. Since the law allowed proportional representation for both company and independent unions, employers strongly "encouraged" its employees to join their company union. In turn, the presence of the company union, along with its right to proportional representation, meant that independent unions could not claim to represent the whole of a work force in a particular industry. 
Consequently, management could circumvent bargaining with independent unions by dealing only with the company union. ${ }^{5}$

Fortunately for the proponents of labor, the law was declared unconstitutional in May of 1935 by the Supreme Court, and was soon replaced with the Wagner Act, also known as the National Labor Relations Act [NLRA], in 1935. The law reaffirmed the main principles of the NIRA, yet corrected its fatal flaw by outlawing company unions. Besides such action, the NLRA prohibited employers from making any financial contributions to labor organizations. Similar to the NIRA, the NLRA also created a labor board, the National Labor Relations Board [NLRB], which served to administer the law. Unlike the NIRA, the Supreme Court upheld the constitutionality of the Act in April of $1937 .{ }^{6}$ And while the NLRA did not set standards for the minimum wage and maximum hours of a worker, the Fair Labor and Standards Act, passed in June of 1938, did. In addition, it also prohibited the practice of child labor, which, coincidentally, had also been advocated by the Bishops' Program of Social Reconstruction in 1919.

While both the NIRA and the NLRA did much to change the views of labor concerning the role of government in the management of industrial disputes, Higgins recognized that the labor movement was still hesitant in its reception of government and the role it could play. Such was evidenced by the AFL's dissatisfaction with the NIRA, as the union argued that the law "was not being enforced vigorously enough," and that labor "had not been given equal representation with Industry and Government in the drafting of... [its] codes." "7 Insofar as the

\footnotetext{
${ }^{5}$ Foster Rhea Dulles and Melvyn Dubofsky, Labor in America: A History (Arlington Heights: Harlon Davidson Inc., 1984), $256-265$.

${ }^{6}$ Ibid., $265-275$.

${ }^{7}$ George G. Higgins, "Voluntarism in Organized Labor in the U.S., 1930 - 1940" (PhD diss., Catholic University of America, 1944), 80.
} 
NLRA was concerned, the AFL argued that the NLRB did not have the authority to resolve conflicts within unions, and could not interfere with the existing contracts between employers and unions. The union even argued against the establishment of minimum wages by the Fair Labor and Standards Act, arguing that the "interests of the workers would be better served by keeping the determination of wages in the field of collective bargaining." 8

In spite of these actions, Higgins believed that "even in its purest form, voluntarism could be reconciled with legislation which would guarantee the right of labor to organize." Furthermore, the guarantee of such a right was the only assurance of it operating effectively. "All that labor asked under voluntarism, and all that it would tolerate by and large, was freedom for itself as one of the principal groups in the economic system to pursue its own economic ends without let or hindrance. If it was to have this freedom in the complete sense, it needed governmental recognition of its right to organize and bargain collectively." ${ }^{9}$ Little was needed beyond this recognition, however, at least in the eyes of unionists.

Higgins understood that American unions feared government control, especially when it came to the practice of collective bargaining. At the same time, it also recognized the necessity of the government's role in the economic realm. The question was how to reconcile the unions', the employers', and the government's role in a managed economy where all institutions had a justified interest. Higgins found his answer in the principle of subsidiarity contained within the Industry Council Plan of Quadragesimo Anno. Subsidiarity recognized the rights of both individuals and associations to accomplish what they may through their own initiative and industry, and argued it was an "injustice and at the same time a grave evil and disturbance of

\footnotetext{
${ }^{8}$ Ibid., 89.

${ }^{9}$ Ibid., 84.
} 
right order to assign to a greater and higher association what lesser and subordinate organizations can do." ${ }^{10}$ This stated, neither did it disqualify the right - nor the authority - of higher associations to involve themselves in the matters of these lesser associations, which for Higgins's intents and purposes was the relation of government to industry and labor.

Consequently, Higgins was uniquely qualified to be McGowan's Assistant Director when he joined the organization in October of 1944. He understood the background and impulses of American labor unions, which would serve as those existing organizations of the economic social order referenced in Pius XI's encyclical. Finally, he understood the conflicted relationship labor had with government prior to his entrance into the SAD, a relationship that fit surprisingly well within the confines of subsidiarity defined in that encyclical. All that would remain was its implementation on the American scene. Unfortunately for both Higgins and the SAD, the passage of the Taft-Hartley Act in 1947 complicated its implementation greatly.

\section{Taft-Hartley: A First and Lasting Obstacle to the SAD Agenda}

The passage of the Taft-Hartley Act in June of 1947 served as a continuing obstacle in the Social Action Department's attempt to establish a new social order based on the principles and precepts of Quadragesimo Anno in the United States. Advocacy for an amendment to the Wagner Act began immediately after the Supreme Court decided in favor of its constitutionality, led by the National Association of Manufacturers and the U.S. Chamber of Commerce. The efforts of these business associations gained traction during the preponderance of strikes that followed the Second World War, led in large part by the CIO in the mass-production industries.

\footnotetext{
${ }^{10}$ Pius XI, Quadragesimo Anno, May 15, 1931, quoted in George G. Higgins, "The Industry Council Program," The Yardstick, November 18, 1946, ACUA/GGH Papers, Box 343, Folder 12.
} 
By 1946, approximately 2,000,000 industrial workers were on strike. ${ }^{11}$ In particular, the halt of steel production raised concern among the public, as thousands of workers were laid off due to the lack of steel in other industries. Besides this, the United Mine Workers went on strike in April of 1946, which forced the government to take over mines in Alabama, Illinois, Indiana, Kentucky, Pennsylvania, and West Virginia. These strikes turned much of the public against the cause of labor, which aided in the ascendancy of the Republican Party in the 1946 midterm elections, and which allowed its passage through Congress in June of 1947.

The proponents of Taft-Hartley sought to redress what they considered an imbalance of power between labor and management, where labor held the upper hand. They asserted that once labor had gained dominance following the passage of the NLRA, it had failed to recognize its influence upon the general public, evidenced by the strikes that had taken place following the war. They argued that the National Labor Relations Act had created these conditions, and so proposed an amendment to the NLRA that would level the playing field. Under Taft-Hartley, unions were prohibited from instituting secondary boycotts or jurisdictional strikes, or from refusing to bargain collectively with employers. ${ }^{12}$ Foremen were denied the right to organize under the statutes of the National Labor Relations Board. Besides these changes, Taft-Hartley also banned the closed shop, and established new, complicated voting procedures for the establishment of union shops. ${ }^{13}$ Even when such procedures were followed by labor to set up

\footnotetext{
${ }^{11}$ Dulles and Dubofsky, Labor in America: A History, 337.

${ }^{12}$ A secondary boycott may be best interpreted as the attempt by a union to influence the actions of a primary business by pressuring secondary companies that conduct business with it. This secondary action may entail the strike of workers at the secondary business in solidarity with the primary union, an appeal to public to refrain from purchasing or supporting the secondary business, and/or the refusal of workers to transport the goods of the secondary company. A jurisdictional strike is the refusal by union members to work as a means to secure their right to work a particular job within a company, or to protests the assignment of a particular job to members of a different union.

${ }^{13}$ A "closed shop" is a business or company that requires all its hires to be a member of a particular union, and is requirement in order to retain employment. The "union shop" is a business or company that does not require union
} 
union shops, the new Act allowed state legislatures to circumvent federal legislation by passing "right-to-work" laws which enabled states to ban the union shop as well. Of final note, the amendment empowered the President to apply for an eighty day injunction against those strikes which threatened national security, which would allow the appointment of inquiry boards to investigate the nature of the strike and propose a solution to resolve it. ${ }^{14}$

The Social Action Department immediately opposed the legislation. Higgins, who wrote the official statement of the department ten days before its passage, argued that Taft-Hartley risked "disrupting industrial relations by hastily recasting the whole range of federal labor legislation just at a time when... collective bargaining shows definite signs of moving towards collective cooperation." The legislation, instead of promoting cooperation between labor and management, would only serve to create more conflict between the two. The bill focused too heavily on the "details of collective bargaining as such," rather than investigating the root cause of the conflict. It was for this reason that Higgins advocated the study of "going beyond the limits of traditional collective bargaining into an organized system of labor-management on the whole range of industrial and economic problems." 15

From the perspective of the SAD, the legislative changes of the Taft-Hartley bill could not have come at a worse time, as the bill recast the legislative landscape entirely. Taft-Hartley only served to promote the class conflict model that had dominated the nation's industrial past, rather than encouraging labor-management cooperation which would better serve its future. Furthermore, these legislative changes did not only allow, but encouraged "management to have

membership in order to be hired, but where the individual must join the union within a pre-determined set amount of time following his or her hiring by the company.

${ }^{14}$ Ibid., $345-346$.

15 Social Action Department of the National Catholic Welfare Conference, "Statement on Taft-Hartley Bill," June 13, 1947, ACUA/USCCB SAD Papers, Box 14 Folder 13, 1. 
recourse to the courts and the Labor Board at almost every turn," which emboldened employers to "sidetrack or evade the normal processes of constructive collective bargaining." "16 Ultimately, Higgins believed that such a course would only bring about more strikes, more strife, and more confusion to the workplace.

Specifically, Higgins and the SAD objected to four basic elements of the bill. First stood the prohibition of the closed shop, which he warned would serve as "an invitation to 'legitimate rebellion on the part of organized labor." The prohibition of the closed shop ignored decades of closed shop labor contracts, which as Higgins pointed out, encompassed hundreds of thousands of workers across the U.S. The loss of these contracts would only invite unrest and confusion in the work place. Secondly, he asserted that the denial of foremen's rights to organize into trade unions of their own free choosing... is at once unethical and impractical.” Higgins predicted once again that this would only serve to promote conflict as these individuals fought to preserve "the free exercise of a right which they know to be theirs and which they are determined to safeguard.” Besides this, the Taft-Hartley Act allowed "separate States to enact anti-labor legislation," particularly that of "the union shop in any of its various and long-established forms." ${ }^{17}$ Finally, Higgins rejected the bill's requirement that all officers of a union had to disavow the Communist Party in order to attain certification by the government. Such a requirement merely served those of the Communist Party, since "a single Communist officer could prevent an otherwise decent and legitimate union from being legally certified for purposes of collective bargaining." Such a practice played "into the hands of the Communists, who thrive on confusion and disorder," which could only be the result of such an instance. ${ }^{18}$

\footnotetext{
${ }^{16}$ Ibid., 2.

${ }^{17}$ Ibid.

${ }^{18}$ Ibid., 3.
} 
In its closing, the SAD public statement urged Congress to "reconsider its vote and to make haste more slowly in its approach to a problem which is far too delicate and far too complicated to be legislated out of existence." ${ }^{19}$ And as might be expected, the department advocated "going beyond the limits of traditional collective bargaining into an organized system of labor-management cooperation on the whole range of industrial and economic problems," meaning the industry council plan promoted by Quadragesimo Anno. ${ }^{20}$

The discussion of the Taft-Hartley Act did not end with this statement, however. Rather, it merely aired the objections which the SAD officially wished to make public. Further discussion and debate over Taft-Hartley continued well past the SAD's official statement, both within the department and in the pages of the Yardstick. Undoubtedly, these departmental discussions helped develop the industry council plan and the department's hopes to implement it on the American scene. Within a year of Taft-Hartley's passage, the department had discussed the basis for industry councils as defined by Quadragesimo Anno, and by the following year of this treatment, McGowan had created his outline of the proposed social order such industry councils would create.

Internally, the department studied the issue and proceeded to create a game plan to replace the Taft-Hartley Act. First and foremost, it asserted that the government had gone too far in its legislative intervention. The duty of government was to "protect the right of the free organization of labor against employers' opposition and the right to bargain collectively," and

\footnotetext{
${ }^{19}$ Ibid.

${ }^{20}$ The Social Action Department's statement on Taft-Hartley inspired an immediate response by supporters of the bill. In particular, David Lawrence, syndicated columnist and the editor of the United States News, objected to the statement on the grounds that economic and political matters fell outside the authority of church organizations, and to interject such organizations in these matters only served to reduce their influence. In Lawrence's view, the realm of the church rested solely on basic moral principles, not specific legislation. The department rejected such a presentation, arguing that defense of Catholic principles required direct action as was shown by its response to TaftHartley (Social Action Department of the National Catholic Welfare Conference, "Memorandum on David Lawrence's Recent Writings," October 31, 1947, ACUA/USCCB SAD Papers, Box 14, Folder 12).
} 
only to intervene in such a way that was "the least that is necessary... so as to protect the people and preserve freedom." Finally, government had to "encourage cooperation [between business and labor] as much as it" could. ${ }^{21}$ From the department's perspective, Taft-Hartley betrayed these principles by restricting labor's organization, its collective bargaining, and its right to strike; it had overstepped its bounds and violated the principle of subsidiarity by removing from labor the necessary structures that enabled industry to solve disputes by "their own initiative and industry." In addition, it created an atmosphere which encouraged class conflict. In spite of this, those within the SAD realized that the Wagner Act had set the stage for Taft-Hartley by not protecting the populace in the event of major strikes, nor by providing the government the means to help labor and management cooperate with one another. Consequently, the department decided to advocate both the repeal of Taft-Hartley and proposed the modification of the Wagner act through additional amendments.

The SAD proposed that an amended Wagner Act should drop the requirement of the TaftHartley Act for unions to file an anti-Communist affidavit, but instead deny legal protection for those unions which were Communist controlled. By doing so, such action would encourage those unions to clean their own houses, so to speak, and to oust those of Communist influence by their own accord. In order to promote union self-action, hearings and a probationary period were necessary in order to allow those unions to act appropriately. The department also advocated the return of the closed shop, since the good of the community outweighed an individual's right to work without organizing. In this sense, the SAD argued that the worker "ordinarily has the duty to organize. ${ }^{, 22}$ Finally, protection of foremen had to be guaranteed through any amendment to

\footnotetext{
${ }^{21}$ Social Action Department of the National Catholic Welfare Conference, "Confidential Brief on the Taft-Hartley Act," ACUA/USCCB SAD Papers, Box 14, Folder 15, 1.

${ }^{22}$ Ibid., 3.
} 
the Wagner Act, since it had not done so and the Taft-Hartley Act had taken advantage of this omission.

The greatest quandary the department faced was the government's role in settling disputes between labor and management, specifically the extent to which the government should involve itself in this conflicted relationship. From the perspective of the SAD, both employers and the working class required a large degree of freedom in their relationship with one another. At the same time however, the department believed that the working class entered into this relationship at an inherent disadvantage to employers and their capital. It argued that "working people own little controllable property, or none at all, in the means of their work," and were constantly "under orders from managers and owners, or both, who decide all the major policies and have the primary power." It was this form of relationship which gave "birth to disputes," disputes which had to "be considered in the light of an attempt to correct, in part, a bad underlying set of facts." 23 These underlying set of facts were the tenets of collective bargaining that promoted conflict between the two parties involved, and Taft-Hartley did nothing to change this. From the viewpoint of the SAD, if the structures that defined the relationship between labor, management, and the government changed, then the relationship between labor and management would change as well. Consequently, it was the role of government to promote economic structures that encouraged cooperation between labor and management, as opposed to conflict. By doing so, the SAD believed the occurrence of disputes between the two would be drastically reduced, which would aid the government in its responsibilities towards the common good.

${ }^{23}$ Ibid. 
At the very least, the SAD called for a "strong and ably-manned mediation and conciliation service" as a part of the Department of Labor. ${ }^{24}$ Such a service would serve the same ends as that of Taft-Hartley by preventing disputes from progressing to such a level where secondary boycotts might take place. In addition, the nature of such disputes required those involved to solve the dilemma themselves, which was practically a necessity since such

Jurisdictional disputes are so complicated that while persons outside of the industry in question can help, and government can induce their settlement, the parties involved are the ones who finally settle the dispute and alone can settle it justly because only they alone know all the facts. ${ }^{25}$

In so far as major strikes were concerned, the SAD recognized such an action on the part of labor could serve to harm the common good. In response, the department advocated that the government require unions to delay major strikes in such circumstances. Such a delay would provide the time necessary to create a "fact-finding board which will make public the facts and thus help the public, employers and unions in the establishment of agreements." ${ }^{26}$ If this failed, the $\mathrm{SAD}$ recommended that the government fine those unions which refused to provide the time necessary to mediate the conflict. And if these measures failed, the department recognized the government's right to seize control and operation of the industry in question, but only as a final recourse. Even in such extreme cases, the department recommended that the government work to resolve the roots of the conflict between management and labor prior to returning control of the industry.

Foreshadowing the industrial council agenda which McGowan and Higgins soon advocated, the SAD argued that governmental "protection of the right of labor to organize and

\footnotetext{
${ }^{24}$ Ibid.

${ }^{25}$ Ibid., 4.

${ }^{26}$ Ibid., 5 .
} 
governmental assistance in settling disputes" alone was not enough. ${ }^{27}$ Instead, the government had to encourage labor-management cooperation. In order for the government to influence such cooperation, new legislation was needed. This new law, an amendment to the Wagner Act, needed to provide for the following:

1.) Inclusion in the preamble of a declaration of the government favoring labormanagement cooperation.

2.) An accepted procedure in the settlement of disputes to encourage labormanagement cooperation with a description of such cooperation in the laws and administrative regulations governing the agencies seeking settlement of disputes.

3.) A federal committee made up of all departments and agencies dealing with the business and labor to search out ways of encouraging business-labor cooperation.

4.) The calling of periodical conferences of the unions with those segments of business which have passed beyond the fighting stage and believe in cooperation with unions.

5.) The extension of business-labor cooperation to agriculture and to the professionals -- all four groups striving for mutual cooperation. ${ }^{28}$

6.) Extension of this cooperation to specific industries, to regions, to states, and to cities. $^{29}$

Through the creation of such a law, a wide range of topics could then be addressed by both labor and management in an atmosphere of cooperation. As the department understood it, the following subjects were ripe for labor-management cooperation efforts:

Cooperation on apprenticeship training; cooperation on methods of production; joint selection of impartial arbiters by labor and management to decide the

\footnotetext{
${ }^{27}$ Ibid., 6.

${ }^{28}$ The SAD understood the term "professionals" as those in white-collar positions, such as lawyers, doctors, and the like.

${ }^{29}$ Ibid., 6.
} 
meaning of collective contracts when the two sides cannot agree; encouragement of industry wide joint committees for the above purposes; jointly controlled health and welfare programs.

Addition of business-labor advisory committees to the National Labor Relations Board; formation of such joint committees in relation to the Federal Trade Commission and to other departments and agencies that deal with business and labor, such as Commerce, Labor, and Interior, Defense ... and the Federal Housing Administration; addition of business and labor members to a joint congressional committee on the workings of a new labor law and addition of farmer members, as well, to the Joint Congressional Committee on the President's Economic Report.

Joint business-labor committees on profit sharing and similar methods of payment income as well as on labor purchase of stock in the companies in which they work. ${ }^{30}$

The potential subjects for cooperation within industry were important if only because they defined the specific areas in which an industry council plan might operate. The changes Taft-Hartley made to the NLRA, and the conditions it fostered, forced the SAD to take action, and specifically define the parameters of its industry council plans at an early stage in its development. Within a year of the Act's passing, McGowan's promotion of an Industry Council Plan had been outlined, and all that remained was for Higgins to carry it out. In many ways, the department's reaction to Taft-Hartley proved that the Social Action Department's response did not simply occur due to the existence of Quadragesimo Anno, but rather developed in response to a legislative event in conjunction with the encyclical's call for social change. Higgins would further define the plan over the years, both in his continued response to Taft-Hartley, as well as the department's need to promote the Industry Council Plan as a means to oppose it.

\footnotetext{
${ }^{30}$ Ibid., 7.
} 


\section{Higgins, Taft-Hartley, and the Industry Council Plan}

As a member of the department, Higgins consistently advocated the repeal of the TaftHartley Act, arguing that the Industry Council Plan might better serve the needs and concerns of both industry and labor. Publicly, Higgins argued that the effort of the SAD to repeal TaftHartley did not represent a pro-union bias, arguing that such a position only served the common good. Regardless of affiliation, the existence of unions was essential in this regard. Organized labor had "a very important role to play in cooperating with management and with government in planning for the general economic welfare," and it could not "possibly exercise its responsibilities in this regard if the law of the land makes it difficult for it to organize and to operate effectively in collective bargaining." 31 And since "the organization of workers (and employers, farmers, and professional people) into their own free associations is an indispensable prerequisite to the establishment of a sound system of social reconstruction," the government then had a responsibility "to encourage organization. It cannot be a matter of indifference to the State whether workers organize or not." ${ }^{, 32}$ Workers had an obligation to organize, and the State had the same obligation to encourage this organization. From Higgins' perspective, all three entities shared an equal importance in managing the field of economics, and all three were essential in the creation and management of such an economic system.

Higgins argued that individual states did not have the right to supersede the federal government when it came to economic organization, especially that of unions. Consequently, he not only refuted the Taft-Hartley provisions which allowed states to supersede federal law in

\footnotetext{
${ }^{31}$ George G. Higgins, "The Real Worry," The Yardstick, November 22, 1948, ACUA/GGH Papers, Box 344, Folder 4.

${ }^{32}$ George Higgins, "Taft-Hartley Versus Unions,” The Yardstick, June 19, 1950, ACUA/GGH Papers, Box 344, Folder 10.
} 
order to limit union shops, but also those that prohibited the closed shop. Indeed, he argued that it would have been "dangerous to invoke the authority of Quadragesimo Anno in defense of the ever-recurring principle of 'states' rights' as opposed to federal intervention in the field of economics. ${ }^{, 33}$ Such an assertion did not betray the principles of subsidiarity which Quadragesimo Anno advocated since it was the federal government's domain to promote the common good in this instance, much in the same way it had done with social security and other general welfare programs. In the instance of state's rights and their efforts to hinder the union shop, it was a matter where lesser organizations were attempting to usurp the domain of the higher organization. This was the mistake "more likely to be made by ultra-conservatives who interpret the principle of subsidiarity so rigidly as almost to exclude the possibility of effective governmental action. Such a mistake only ignored "the numerous references in the encyclical to legitimate governmental programs in the field of social welfare and social reform."34

Higgins also found support for his arguments against Taft-Hartley in arenas outside that of the Church, specifically that of the Supreme Court. Of particular importance was its 1956 Railway Labor Act decision, where the court rejected the argument that union shops were in violation of the First Amendment. The argument that union shops violated First Amendment rights was common to proponents of right-to-work legislation, and this decision directly refuted that argument. Unfortunately for Higgins and the SAD, the decision did not affect Taft-Hartley, but only affected railway and airline union shop workers since their industries fell under the federal government's domain of interstate commerce. However, the decision by the court opened a legal avenue to challenge Taft-Hartley. Higgins pointed out the opinion of Justice William

\footnotetext{
${ }^{33}$ George G. Higgins, "The Industry Council Program,” The Yardstick, November 18, 1946, ACUA/GGH Papers, Box 343, Folder 12.

${ }^{34}$ George G. Higgins, “Controversy over a Word,” The Yardstick, September 4, 1961, ACUA/GGH Papers, Box 347, Folder 7.
} 
Douglas, who in his treatment of the case argued that this "provision of the Railway Labor Act... [provided] 'no more an infringement or impairment of First Amendment rights than there would be in the case of a lawyer who by state law is required to be a member of an integrated bar."' Such a stance was important since it created ties between the union shop and integrated bar associations, which Higgins argued were "the equivalent of a closed shop for members of the legal profession." In addition, Higgins recognized that since bar members had to pay fees in order to practice law in their respective states, it could be argued that bar associations practiced in a similar manner to the union shop, which required the same. Thus, "according to the logic of the Court's decision on the Railway Labor Act, a simple amendment to the Taft-Hartley Act to bring it into conformity with the former statute would be enough to invalidate right-to-worklegislation in all industries engaged in interstate commerce." ${ }^{35}$ In other words, even though TaftHartley might not be repealed, Higgins hoped to at least limit its proscriptions against the union shop.

Unfortunately for Higgins, Taft-Hartley was never repealed. It remained on the books, and so presented a constant obstacle to the agenda of the Social Action Department. However, its presence did not stop Higgins and his attempts to institute an Industry Council Plan. In many ways Taft-Hartley was a fortunate occurrence for the department, in that it helped further define the Industry Council Plan advocated in Quadragesimo Anno. Such was the task Higgins faced throughout his time as Assistant Director and Director of the department, lasting until he left the directorship to become a consultant in 1972. Through his work on The Yardstick, as well as through various lectures he gave over the years in his capacity as a member of the organization, Higgins fleshed out the bones of the Industry Council Plan as outlined by McGowan in 1948.

\footnotetext{
${ }^{35}$ George G. Higgins, "Unions and the Bar - A Parallel," The Yardstick, June 4, 1956, ACUA/GGH Papers, Box 345, Folder 14.
} 
Higgins and those within the SAD believed that following the Great Depression, America faced a new horizon as it lay to rest the evils of economic liberalism espoused by laissez faire capitalism. Laissez faire as a principle, meaning "its plausibility as a workable and/or ethical philosophy of economic life," had been "irremediably damaged." In the same breath, however, Higgins believed that if "laissez faire ... is a skeleton, it is by no means in the closet;" the dangers of laissez faire capitalism persisted. ${ }^{36}$ Fortunately, along with the discrediting of laissez. faire, neither had its opposite ideology held sway - that being socialism. These circumstances, while beneficial in eyes of Higgins and his contemporaries, still left the nation's economy in a precarious position. The nation retained a "mixed and rather highly collectivized economy without any clearly established principle of unity and authority," which contributed to confusion in the marketplace since no established economic order had taken hold. This lack of economic order was a danger in and of itself, since it would not - nor could it not - remain in a state of flux. In the opinion of Higgins, it was only a matter of time before it would "either be reorganized around the principles of Quadragesimo Anno, for better or for worse," or it would be "disciplined and ordered by the machinery of the State. This is the American dilemma, therefore, as of 1951: how to establish effective social controls over a predominantly private but already highly collectivized economy without becoming totalitarian in the process." ${ }^{37}$

For a democracy such as the United States, the answer to such a question lay in its responsibilities to foster social justice and improve "world economic management." But such an attempt presented dangers as well, for the pursuit of such would "inevitably involve the risk of having too many functions of social life controlled by the State from above," and thus by its very

\footnotetext{
${ }^{36}$ Harry K. Girvetz, From Wealth to Welfare: The Evolution of Liberalism (Stanford: Stanford University Press, 1950), 121, quoted by George G. Higgins, "1952 Catholic University of America Workshop Talk," (talk presented at the Catholic University of America, 1952), ACUA/GGH Papers, Box 323, Folder 10, 5.

${ }^{37}$ George G. Higgins, "1952 Catholic University of America Workshop Talk” (talk presented at the Catholic University of America, Washington, D.C., 1952), ACUA/GGH Papers, Box 323, Folder 10, 7.
} 
actions in promoting the common good, it would only serve to become the antithesis of democracy. Consequently, from Higgins' vantage, "big government" was the "direct and inevitable consequence of economic liberalism," and it was this lack of social justice which demanded the government's intrusion, and served as the impetus for establishing a totalitarian state. $^{38}$

Quadragesimo Anno and its Industry Council Plan provided the answer to the government's dilemma, for it supported those structures of social justice which the government craved, but also allowed it to focus on other matters, and by doing so retain its democratic principles without threat of totalitarianism. ${ }^{39}$ For those of the SAD, the Industry Council Plan of the encyclical represented a "pluralist society in which 'all forms of social and economic activity, even the largest and most comprehensive ones, would start from the bottom.” In other words, it supported the " free initiative of and mutual tension between the particular groups... rising in tiers and institutionally recognized."” By the creation of such a social order, "“a definitely personalist and pluralist pattern of social life would come into effect in which new societal types of private ownership and enterprise would develop. And the State would leave to the multifarious organs of the social body the autonomous initiative and management of all the activities which by nature pertain to them. Its only prerogative in this respect would be its

\footnotetext{
${ }^{38}$ Ibid., 15.

${ }^{39}$ Higgins relies heavily upon Jacques Maritain's Man and the State in his argument concerning social justice and its relation to government. Accordingly, Higgins praises Maritain as a realist, "unlike the typical American conservative who is afraid of too much government, and very properly so of course, but is unable or unwilling to face up to the central fact of modern economic life, namely that big government, normally speaking, is the more or less direct and inevitable consequence of economic liberalism." Thus, Maritain's work serves as the foundation for Higgins' belief that the fruits of economic liberalism are the cause of social injustice, and whose presence constitutes a threat to true democracy.
} 
genuine prerogative as topmost umpire and supervisor, regulating these spontaneous and autonomous activities from the superior political point of view of the common good.", 40

It was the hesitancy to leave laissez faire as a failed policy - and to recognize it as such that made the implementation of the Industry Council difficult. "The philosophy of free competition --- modified, to be sure, by the impact of both fact and theory is lodged in our emotional blood stream and breaks out in goose pimples, as it were, whenever we seriously face up to all the implications of the Industry Council program." ${ }^{41}$ Again, government served as part of the answer, but not the answer itself. Higgins argued that people have a "natural tendency... to follow the path of least resistance and run to the government too soon for the solution of these economic problems which are the inevitable byproducts of our present disorganized and 'confused' collectivism." should "consciously encourage unions and trade associations to cooperate with one another for the solution of as many of their own problems as possible," for by doing so it freed the State to focus on matters of greater importance. ${ }^{43}$

It was for this reason that Higgins relegated the role of legislation as "patch-work at best" in its level of importance, since focusing solely on legislation as the answer to labor-management problems closed "our eyes to the need for a more basic type of reform and reconstruction." 44 Furthermore, in light of the Taft-Hartley Act, neither could the government be fully trusted to implement the right legislation needed for the common good. Reform of the system had already

\footnotetext{
${ }^{40}$ Jacques Maritain, Man and the State (Chicago: The University of Chicago Press, 1951), 23, quoted by George G. Higgins, "1952 Catholic University of America Workshop Talk" (talk presented at the Catholic University of America, Washington, D.C., 1952), ACUA/GGH Papers, Box 323, Folder 10, 9.

${ }^{41}$ Ibid., 10.

${ }^{42}$ Ibid., 11.

${ }^{43}$ Ibid., 12.

${ }^{44}$ George G. Higgins, “Legislation is Not Enough,” The Yardstick, June 3, 1946, ACUA/GGH Papers, Box 343, Folder 10 .
} 
been much accomplished with the implementation of the Bishops Program of Social

Reconstruction of 1919, of which ten of their eleven proposals had been adopted in some

measure by the state. ${ }^{45}$ Consequently, what was now required was the reconstruction of the social order, which in order to protect the democratic populace from the threat of totalitarianism, had to arise from the bottom up, rather than originate from the state itself.

This was not to say that government did not have a strong role in the creation of such a social order, however. Acknowledging that such an interpretation could stem from his own writings and that of the Department, where at times they had failed to emphasize "the positive role of government in economic life as forcefully as we sometimes deprecate excessive governmental intervention," Higgins assured his readership that subsidiarity, as a principle, was not "anti-governmental in the reactionary sense of the word." Rather, the government's role was essential to the success of the Industry Council Program. Specifically, the establishing of such an order was a critical undertaking on the part of the government, since the State would have "to intervene rather frequently, and more or less directly, both to correct specific injustices and to foster the growth of the industry councils and their federation" as the system stabilized in its formation. Quoting the encyclical, he asserted that even when such a social order had come to fruition, the state would still have to do "all those things that belong to it alone because it alone can do them: directing, watching, urging, restraining, as occasion requires and necessity demands." Consequently, Higgins argued that the principle of subsidiarity "offers... little solace to the advocates of laissez-faire as it does to outright Socialists."46

\footnotetext{
${ }^{45}$ According to John A. Ryan, the only proposal that had not been adopted to any large degree was the bishops' call for greater participation in management and the co-ownership of industrial property through employee stock (John A. Ryan, "The Bishops' Program of Social Reconstruction," The American Catholic Sociological Review 5 (March, 1944): 31).

${ }^{46}$ George G. Higgins, “Subsidiarity,” The Yardstick, January 29, 1951, ACUA/GGH Papers, Box 344, Folder 13.
} 
Higgins envisioned the Industry Council as a federation of existing unions, trade and professional associations, and employer's organizations. This federated system was a necessity since legislation could lead to statism, but in the same breath "organization alone - along class lines - can easily result in an all-out struggle for domination between or among contending economic power groups. ${ }^{, 47}$ In this sense, Higgins and the SAD promoted class collaboration as opposed to class struggle. Part and parcel to this federated system of employers, workers, professionals, and agriculturalists, was the expansion of collective bargaining beyond its current scope. Recalling the Labor Day Statement issued by the SAD in 1946, Higgins argued that collective bargaining “"over wages, hours, and working conditions - traditional collective bargaining - is no longer sufficient, if indeed it ever was sufficient, for the solution of the socalled labor problem." Social justice required that "organized labor and organized management come together in an occupational group system -- an organized system of cooperation for the solution of all the major problems of economic life."48

Forming such a federation served the common good, since such an organization would also "be held publicly responsible for their abuse of power," since "the main burden of responsibility for economic justice and industrial peace" would depend on both labor and management. ${ }^{49}$ Furthermore, such a system would promote a social order, where "labor and management, instead of struggling against one another as belligerent contestants in the arena of the marketplace will recognize their mutual dependence and cooperate, over the whole range of economic problems, to advance their own economic welfare and to promote the common

\footnotetext{
${ }^{47}$ George G. Higgins, "Reconstruction through Industry Councils," The Yardstick, May 1, 1961, ACUA/GGH Papers, Box 347, Folder 7.

${ }^{48}$ George G. Higgins, "Industry Councils," The Yardstick, February 23, 1948, ACUA/GGH Papers, Box 344, Folder 1.

${ }^{49}$ George G. Higgins, “Legislation is Not Enough,” The Yardstick, June 3, 1946, ACUA/GGH Papers, Box 343, Folder 10.
} 
good." 50 The expansion of the scope and definition of collective bargaining was essential in accomplishing such a federation, since the current understanding, whereby only wages, hours and working conditions were addressed, only served to "perpetuate a spirit of conflict between labor and management." The federated industry council provided the answer by changing the dialogue to one of collective cooperation, for inherent to the system was the discussion of "such matters as prices and production schedules in addition to wages, hours and working conditions."

Higgins had reason to believe that such a system would work, citing the experience of the Crown Zellerbach Corporation and the Pacific Coast Pulp and Paper Industry of 1948. This company, which worked with the International Brotherhood of Pulp, Sulphite, and Paper Mill Workers, a member of the AFL, had remained strike free since 1934. Higgins argued that their working relationship served as an example of industrial peace and served as a model for the type of class cooperation necessary in the new social order promoted by Quadragesimo Anno's Industry Council Plan. This industrial peace had lasted due to the following factors:

The parties have largely relied upon themselves to settle controversies without resort to third parties.

The unions have felt institutionally secure from management attacks. Negotiations have been conducted without due delay.

The parties have shown a disposition for mutual discussion of a wide range of subjects.

The contracts have been observed religiously by both parties.

The representatives of both sides have shown a high degree of respect for each other.

The workers have benefitted from relatively good wages and security.

Turnover and absenteeism have been low.

\footnotetext{
${ }^{50}$ George G. Higgins, "Industry Councils," The Yardstick, February 23, 1948, ACUA/GGH Papers, Box 344, Folder 1.

${ }^{51}$ Ibid.
} 
Joint collusive actions against competitors or purchasers have not occurred. ${ }^{52}$

This was opposed to the experience of the steel industry crisis of 1959 , where the collective bargaining atmosphere had steadily deteriorated over the years. Higgins believed that the then current steel industry strike represented "a deep-seated philosophical or ideological disagreement between labor and management in big steel over the meaning and scope of collective bargaining." This view had been supported by the U.S. Chamber of Commerce as well in its August issue of Nation's Business, which also attributed the current tone of the conflict to the "business community's increasing concern over union encroachment on the responsibility to manage." 53

As a result, Higgins had little hope for the resolution of the strike since the steel industry had "yet to learn that collective bargaining is a two-way street and that any attempt to convert it into a one-way street for either management or labor is a clear invitation to class warfare." Ultimately, this was unfortunate for both parties, since "the scope of collective bargaining cannot be legalistically determined in a theoretical vacuum." Rather, it had to "be flexible enough to cope realistically with the particular needs of individual plants and companies and with the new and increasingly complicated problems which are constantly arising in... [the United States'] rapidly changing economy." 54

Once such a federation existed (and operated) for the benefit of the common good, it would promote a return to the natural social order that had existed prior to the advent of laissez faire capitalism. In many ways such an order would signal a return to the true nature of man,

\footnotetext{
${ }^{52}$ George G. Higgins, "They Do Get Along," The Yardstick, September 20, 1948, ACUA/GGH Papers, Box 343, Folder 3 .

${ }^{53}$ George G. Higgins, "Invitation to Class Warfare,” The Yardstick, August 24, 1959, ACUA/GGH Papers, Box 346, Folder 11.

${ }^{54}$ Ibid., 2.
} 
which had been disrupted by economic liberalism. Higgins argued that man "is by nature a social being with social responsibilities, which responsibilities, to speak only of economic life for the moment, cannot be effectively carried out by unorganized individuals acting as competing units in society." Neither was this the sole responsibility of the worker alone, since every person, whether that be the "worker, employer, farmer, or professional man," was "obliged by the virtue of social justice to join his associates to carry out all of those responsibilities which of himself alone he is incapable of fulfilling." In the same manner, Higgins argued that every "economic association -- of workers, farmers, employers, or professional people - is obliged by the virtue of social justice to cooperate among themselves and with the government to accomplish those social objectives which are common to all of them and which none of them, acting on its own in isolation from the others, can possibly accomplish."55

Such a social order had existed in medieval times, evidenced by the guilds referenced in Quadragesimo Anno. Higgins and the SAD recognized that American unions and business associations were certainly not guilds in the sense that the encyclical understood them, but believed that they could espouse the principles of cooperation that guilds had represented in medieval times, and which Pius XI's encyclical promoted. ${ }^{56}$ This form of cooperation epitomized the organized economic society which Higgins and those of the Social Action Department hoped to foster in the present day, at least in so far as the production, management, and sale of goods was concerned. Nature intended humanity "to organize for this purpose -- to 'form guilds or associations' and through these 'self-governing associations' to regulate economic life according to the requirements of social justice" Furthermore, these "guilds" were not "the creatures of

\footnotetext{
${ }^{55}$ George G. Higgins, "Encouraging Labor to Organize," The Yardstick, November 24, 1947, ACUA/GGH Papers, Box 343, Folder 16.

${ }^{56}$ Quadragesimo Anno perceive unions as
} 
government," for they were considered "natural organizations and, to the greatest possible extent, they are to be self-governing." ${ }^{, 57}$ The government's role remained one of supervisor and coordinator in this regard.

As a part of the natural order, this presentation could not be considered as solely a Catholic concept. Being a state of the natural order, whose organization stems from the natural law, meant that it was based "upon the nature of man and the nature of society," and so it could be recommended to "all right-thinking Americans, whatever their religion." Such was the case, evidenced by Walter Reuther's promotion of such a program under the auspices of the United Auto Workers in the early 1940s. As a Protestant, Reuther's endorsement of a similar program proved that such a plan crossed denominational lines, appealing to all Christians. Neither was Reuther alone in such promotion of an industry federation either, at least in so far as his position as a unionist. Philip Murray, the president of the CIO and a Catholic, had also promoted a similar program, albeit limited to the mass production industries.

Ultimately, such a federation of industries required the organization of the work force, as well as that of management. Higgins believed that management was already organized, despite protestations that it was not. Citing the directory of the Department of Commerce and its expansive membership of trade associations, Higgins argued that "American businessmen are very highly organized, much more so, as a matter of fact, than the workers" were. ${ }^{58}$ Consequently, Higgins believed that it was the work force, much more so than management,

${ }^{57}$ George G. Higgins, “An Organized Economic Society,” The Yardstick, April 24, 1950, ACUA/GGH Papers, Box 344, Folder 10.

${ }^{58}$ George G. Higgins, "1952 Catholic University of America Workshop Talk" (talk presented at the Catholic University of America, Washington, D.C., 1952), ACUA/GGH Papers, Box 323, Folder 10; Higgins cites that some fifteen hundred national trade associations were listed in the Department of Commerce's directory, as well as approximately an additional three hundred associations comprised primarily of businessmen. These trade associations claimed a membership exceeding one million business firms. From Higgins's vantage, this was an encouraging statistic, in that management was organizing rapidly, and that Americans were "not as individualistic as they sometimes pretend to be" (Ibid.). 
which needed organization, especially if such an Industry Council system was to succeed. This was a matter of the general welfare, and so a matter of government responsibility to foster such organization. The "organization of workers (and employers, farmers, and professional people) into their own free associations is an indispensable prerequisite to the establishment of a sound system of social reconstruction." In turn then, the state had a duty "to encourage organization. It cannot be a matter of indifference to the State whether workers organize or not." In fact, according to Higgins, the workers had "an obligation to organize," at least according to these principles. $^{59}$

Invariably, promotion of such an economic system also brought about a defense of the same. In the case of Higgins and the Industry Council Plan, the most common charge was that an industry federation was incompatible with both capitalism and democracy. More often than not, Higgins had to defend the industrial council plan against the charge of fascism, since many of its opponents interpreted the proposal as being controlled completely by government. Higgins argued that this was not the case, and that Quadragesimo Anno did not support any fascist system. "The fact of the matter... is that Quadragesimo Anno explicitly differentiates between the vocational group system and the fascist corporative order, and it openly rejects the latter." Moreover, the vocational system described in the encyclical was inherently democratic, for a “fascist system operates tyrannically from the top down through politically appointed and politically controlled representatives. The vocational group system on the contrary... works for

\footnotetext{
${ }^{59}$ George G. Higgins, “The Real Worry,” The Yardstick, November 22, 1948, ACUA/GGH Papers, Box 344, Folder 4.
} 
the general welfare from the ground up through freely chosen representatives from bona fide trade unions and bona fide organizations of employers. It's the very antithesis of fascism."60

Neither was the Industrial Council plan an adaptation of corporative fascism, where industry federations were "merely semi-governmental bodies to which the legislative authority delegates a certain number of powers, shared with the trade unions in joint committees presided over by representatives of government." From Higgins point of view, such a system would have been intolerable, since the unions and associations of the council system would have only served as "instruments of power in the hands of a political dictatorship." 61 Rather, in the case of an Industry Council in the United States, the government would work with unions and management in partnership. The real issue, according to Higgins, was that the opponents of the Industry Council program could "not admit the possibility of a typically American -- and therefore democratic -- version of economic "corporativism.",62

Nor did the implementation of the industrial council program threaten capitalism, since private ownership was maintained as a part of the social order. It was true that the new social order promoted co-ownership of private property, but only in the sense that workers had "to somehow become owners, at least in part, of the instruments of production." This could occur in a myriad of ways, although an arrangement where workers "own a substantial part of the corporate stock and exercise a reasonable share in the management" of the company was preferred. Such an arrangement maintained private property rights and ownership, since the

\footnotetext{
${ }^{60}$ George G. Higgins, "Misinterpreting Catholic Teaching,” The Yardstick, July 29, 1946, ACUA/GGH Papers, Box 343 , Folder 11.

${ }^{61}$ George G. Higgins, “The 'Consultative' Approach,” The Yardstick, August 13, 1951, ACUA/GGH Papers, Box 344, Folder 15.

${ }^{62}$ George G. Higgins, "Industrial Democracy," The Yardstick, August 20, 1951, ACUA/GGH Papers, Box 344, Folder 15.
} 
“"instruments of production... would still be owned by the individuals, not by the State.",63

Higgins felt comfortable in these assertions since the social encyclicals only rejected those tenets of capitalism which argued that "free competition in an unregulated market economy should be the guiding ethical norm of economic life." In this sense, the encyclicals did not reject "the market economy as such, nor competition as such, nor capitalism as such."

Thus, the Industry Council Plan remained the best way, the middle way between totalitarian government and extreme individualism. The principles of the Industry Council Plan guided Higgins throughout his time at the Social Action Department, and served as the basis for his recognition as a "labor priest." Such recognition was warranted since Higgins supported the place of unions on the American economic scene, but not to the effect that unions were infallible. Rather, they were "a moral and economic necessity not only for the workers, but also for the economy as a whole." From Higgins' view, unions were "indispensable to the development of a sound social order." It did not mean that he inherently supported the practices and agenda of all unions, since there existed "a number of abuses in the labor movement as there are in every other organized group in the American economy." ${ }^{64}$ Rather, Higgins sought to protect and foster any movement or legislation which promoted the rights of labor to organize, and respected their efforts at collective bargaining. More so, he hoped to foster a social order whereby collective bargaining might become industry-wide, and thus serve as the impetus to create the federation of industries which Quadragesimo Anno promoted. Throughout his efforts, the right to organize, which he interpreted as a duty of the individual, remained the lynchpin for this new social order.

\footnotetext{
${ }^{63}$ George G. Higgins, “Unfinished Business,” The Yardstick, February 28, 1955, ACUA/GGH Papers, Box 345, Folder 9.

${ }^{64}$ George G. Higgins, "No Pro-Labor 'Bias,"” The Yardstick, July 25, 1955, ACUA/GGH Papers, Box 345, Folder 11.
} 
Conversely, Higgins would oppose any movement or legislation which might hinder the organization of workers and their rights to do so.

The effort to create such a system was obstructed by the passage of the Taft-Hartley Act, particularly through its restrictions of union shops and its prohibition of the closed shop. By 1955 seventeen states had enacted right-to-work legislation, effectively prohibiting the union shop and restricting union organization. As a result, Taft-Hartley effectively remodeled the work place. Workers could choose not to join a union, knowing they would gain many of the same benefits obtained by the collective bargaining of their affiliated co-workers. At the same time, dutiful members paid their dues and watched in frustration as non-union members received those benefits. Consequently, the atmosphere created by Taft-Hartley undermined the organizational efforts of the unions, and promoted a sense of apathy among its members. Unfortunately, the SAD's agenda relied largely on the working class and its organization. Higgins hoped to address the issue when he became director in 1954, but national events required him to focus on the preservation of the labor movement instead. Soon following his appointment, a Senate investigation lead by John L. McClellan focused on the presence and influence of corruption within the American labor movement. As a consequent, the United Auto Workers created the first union public review board, for which Higgins served as a member, and later as its chairman. Fortunately for Higgins, these circumstances helped him develop his understanding of union apathy and its place within the labor movement, as well as its theological remedy. The following chapter will detail Higgins's involvement and contributions to the labor movement during the McClellan Committee's existence, and his time on the UAW Public Review Board. 


\section{Chapter 4}

\section{Higgins's Introduction to the Directorship: The Crisis of the McClellan Committee and Its Implications for the Labor Movement}

As of today ... it is a pleasure for this member of the Public Review Board to associate himself with the Chairman when he says, in the final paragraph of his Preface [to the first annual report] that 'the creation of the Public Review Board reveals the high degree of stability, responsibility and moral health which American labor possesses and indicates that it has the capacity for self-discipline to enable it increasingly to remove the deficiencies and inequities from which no large organization is entirely free.'

- Rev. George G. Higgins, The Yardstick, Dec. 29, 1958

$$
\phi
$$

Higgins succeeded Raymond McGowan as the director of the Social Action Department on November $20^{\text {th }}, 1954 .^{1}$ As director, Higgins maintained the course set by McGowan, including the day-to-day activities that managing such an organization as the SAD required. The department's social education work continued - this included both Higgins's Social Action Notes for Priests and its lecture and conference circuits promoting social justice. The Catholic Association for Peace continued to promote a peace based on papal and encyclical pronouncements and of applying Christian principles to international affairs. The Inter-American Catholic Social Action Confederation maintained an international presence through its conventions, continuing its work for economic justice. Meanwhile, Msgr. Cronin, apart from his promotion to Assistant Director to Higgins, continued his work against communism, arguing that

\footnotetext{
${ }^{1}$ N.C.W.C News Service, "Msgr. George Higgins Named Director of Social Action Department of N.C.W.C.," Nov. 22, 1954. ACUA/GGH Papers, Box 417, Folder 5, 1.
} 
it "would be dangerous to relent in the struggle ... so long as it remains what it is, a diabolical conspiracy against God and freedom.."2

The focus of the department remained much the same as it had been under McGowan as well. The hopes of an Industry Council Plan were ever present, as well as the challenges that the fruits of Taft-Hartley presented in its implementation. Consequently, Higgins retained the vision set by his predecessors, which was the creation of a new order built upon the cooperation of classes rather than their conflict. Present day circumstance challenged this vision, however, requiring Higgins to adapt it to the trials that he and the department faced soon after his tenure began. Two events, common in nature but separate in circumstance, would challenge the labor movement and its place within American life. First and foremost was the physical attack on Victor Riesel in 1956, a popular labor columnist from New York; second was the creation of the McClellan Committee some ten months later. The assault on Riesel brought the nation's attention to bear on the evils of corruption within the labor movement, while the McClellan Committee took advantage of this attention and placed a spotlight on the problem at hand. The presence of corruption within the labor movement was undeniable, and required immediate action by the leaders of labor, as well as its supporters. It was an issue that Higgins could not ignore. The findings of the McClellan Committee threatened the life of the labor movement, and the organization of the working class was essential to the SAD's social agenda.

From the start of his career as a labor priest, Higgins had maintained a vocal position against racketeering and the presence of communism within the unions, arguing that the "friends of labor were always as interested in eradicating [racketeers and communists] as are its

\footnotetext{
${ }^{2}$ National Catholic Welfare Conference, "Annual Report of the Department of Social Action, Washington, D.C., 1955,” ACUA, Reading Room Stacks, 12.
} 
enemies." ${ }^{33}$ The practice of racketeering was an affront to the values on which the labor movement had been founded, and its presence a threat to its very existence. Accordingly, Higgins called upon the unions to take action and to provide the necessary structures and mechanisms which would purge the unions of its influence. This call was an urgent one, for if the unions themselves did not take action, then the government would. Fortunately for the movement, its leaders decided to clean their ranks and to establish new codes of ethics meant to police and prevent racketeering. In the case of the International Union, United Automobile, Aerospace and Agricultural Implement Workers (UAW), not only did it abide by the new codes of ethics that had been implemented, it also established a public review board meant to provide the rank and file with the means better to police themselves and their fellow members. Higgins joined the Board in 1957, and later served as its chairman from 1966 to 2000. As a member of this Board, Higgins considered it an essential component of the effort to maintain the democratic nature of unions, since review boards empowered the rank-and-file and encouraged them to take a greater role in the management of their unions and the maintenance of their integrity. As a direct consequence, he recommended the adoption of review boards by all unions throughout the labor movement. For Higgins, the presence of the Board proved that corruption of the unions was not due to the failures of its leadership, but was rather a symptom of the spiritual malaise found within its rank-and-file. If the labor movement wished to survive and regain the respect of its peers, then the rank-and-file would have to recognize that even though unions were secular institutions, they rested upon spiritual principles of sacrifice. The rank-and-file would have to recognize these principles, and recommit them to the cause in the same way their predecessors had.

\footnotetext{
${ }^{3}$ George G. Higgins, "Speaking of Labor Unions," The Yardstick, February 11, 1946, ACUA/GGH Papers, Box 343, Folder 9.
} 


\section{Victor Riesel and the Creation of the McClellan Committee}

While the presence of racketeering in unions had always been a factor in union life, it was the blinding of Victor Riesel on the evening of April 5, 1956 that focused public attention on the issue. Having finished a radio broadcast that evening, Riesel had just exited Lindy's restaurant off Broadway in New York when Abraham Telvi blinded him with sulfuric acid. Riesel's syndicated column appeared in over three-hundred newspapers throughout the country, and the attack made national news. Growing up in New York, Riesel had followed in his father's footsteps as a union activist by focusing on the corruption present in labor unions, and how such corruption was detrimental to the movement. At the time of the attack, Riesel had agreed to testify before a grand jury investigating racketeering in the garment and trucking industries. ${ }^{4}$ As one might expect, Abraham Telvi was not the mastermind of the attack, but rather a pawn in a larger conspiracy. The federal government indicted John Dioguardi, along with six other men, with the charge of conspiracy to obstruct justice by blinding Riesel. ${ }^{5}$ Telvi himself was never charged, due to his murder shortly after the incident. ${ }^{6}$ In addition, Dioguardi was never convicted of the crime, for the case never went to trial. ${ }^{7}$ Even though the prosecution's main witnesses, Gondolfo Miranti and Domenico Bando, had agreed to testify in order to receive reduced sentences, they later refused to testify. The prosecution believed witness intimidation was the main factor for their actions. ${ }^{8}$

\footnotetext{
${ }^{4}$ Pete Hamill, "In Defense of Labor: They Spent Many Years Fighting the Same...," The New York Times, Dec. 31, 1995.

5 Edward Ranzal, "Jury Indicts Dio in Riesel Attack," The New York Times, Sep. 8, 1956.

${ }^{6}$ Stanley Levey, "F.B.I Solves Riesel Case; Reports Acid-Hurler Slain,” The New York Times, Aug. $18,1956$.

7 "Dio, 2 Others Convicted of Conspiracy," The Washington Post and Times Herald, July 26, 1957.

${ }^{8}$ Edward Ranzal, "Dio Case Dropped from Court Docket," The New York Times, May 28, 1957.
} 
The event did not escape Higgins' notice or commentary. Higgins asserted that if those involved in the attack were labor union members, then these unionists had become "their own worst enemies." Their actions had done "more to arouse public opinion against themselves ... than their unfortunate victim could have done in literally hundreds of columns and speeches in the past 10 or 15 years. ${ }^{\prime 9}$ At the same time, Higgins defended labor leaders against the charge of turning a blind eye to the problem of racketeering. Higgins hoped that Riesel himself would clarify this to the public, stating that "trade unionism is not only desirable but necessary, and that, to his personal knowledge, the overwhelming majority of American labor officials are just as much opposed to labor racketeering as he is." Regardless of that action however, Higgins believed "a full-scale Congressional investigation of labor racketeering" was likely to occur. ${ }^{10}$ Riesel had already argued that Congress had shirked its duties and demonstrated negligence by not having conducted such an investigation already. ${ }^{11}$ Riesel would soon get his wish.

The Senate created the Select Senate Committee on Improper Activities in Labor or Management Field on January 30, 1957. A bipartisan committee, it had the jurisdiction to investigate matters involving corruption in labor management relations, and was composed of eight senators: Samuel Ervin (D, North Carolina), Barry Goldwater (R, Arizona), Irving Ives (R, New York), John F. Kennedy (D, Massachusetts), Joseph McCarthy (R, Wisconsin), Patrick McNamara (D, Michigan), John L. McClellan (D, Arkansas), and Karl Mundt (R, South Dakota). The Select Committee was soon known as the McClellan Committee, named after its chairman. As chairman, McClellan focused on racketeering within unions, and defined the practice as any of the following: the joint action between employer and union officials to deprive union

\footnotetext{
${ }^{9}$ George G. Higgins, “Too Much Winking at Labor Racketeering,” The Yardstick, April 16, 1956, ACUA/GGH Papers, Box 345, Folder 14.

${ }^{10}$ George G. Higgins, "Labor's Biggest Current Problem," The Yardstick, July 16, 1956, ACUA/GGH Papers, Box 345 , Folder 15.

11 "Riesel Urges Congress to Probe Acid Hurling," The Los Angeles Times, June 4, 1956.
} 
members of their rights; the manipulation of union welfare funds for personal gain; the payment of personal expenses through union funds; and the use of union power to control gambling and other vices of the working man. By investigating the presence of such practices within unions, the Committee hoped to

expose any illegal or improper practices or activities in these areas and to ascertain what changes, if any, are needed in the laws of the United States to prohibit and protect both labor and management and the public interest against a continuation or recurrence of such wrongdoing. ${ }^{12}$

Given its broad authority, the Committee placed both unions and management under its purview, although during its three year history the Committee mainly focused on the union side of that relationship. $^{13}$

\section{Labor Cooperates: The AFL-CIO's Response to the McClellan Investigation}

In response to the creation of the McClellan Committee, American labor assumed a posture of cooperation throughout its investigation. As a part of this effort, many unions argued that they had begun to address the problem long before the creation of the Committee, and provided examples of their ongoing efforts to fight corruption and remove its influence. In December of 1957 the AFL-CIO specifically addressed the issue of corruption at its third annual convention. Citing its founding constitution, union leaders reminded its members that one of the “objects and principles of this Federation" was to "protect the labor movement from any and all

\footnotetext{
${ }^{12}$ Editorial Staff of the Bureau of National Affairs, Inc., The McClellan Committee Hearings - 1957 (Bureau of National Affairs, 1958), 425.

${ }^{13}$ In January of 1955, Robert F. Kennedy was appointed to work as an investigator for the Senate Permanent Subcommittee on Investigations. As counsel, Kennedy scrutinized the contractors and government officials of the clothing-procurement program for the Military Services, where he discovered the infiltration of East Coast mob officials, including John Dioguardi. Kennedy's investigative path followed that of a domino chain, each lead opening an avenue of investigation, which demonstrated evidence of nation-wide corruption. It was this evidence, along with the public outcry resulting from Riesel's blinding, which led to the creation of the committee.
} 
corrupt influences." ${ }^{.14}$ In addition to this basic principle, the constitution had provided for the establishment of a Committee on Ethical Practices, which was "vested with the duty and responsibility to assist the Executive Council [in its responsibility] to keep the Federation free from any taint of corruption... in accordance with the provisions of this constitution. ${ }^{, 15}$ To this end, the Executive Council and the Committee on Ethical Practices of the AFL-CIO had investigated four unions prior to the creation of the McClellan Committee: the Allied Industrial Workers; the Distillery Workers; the Laundry Workers; and the Bakery and Confectionery Workers. Besides these member organizations, the same Council had investigated two other unions, the United Textile Workers and the International Brotherhood of Teamsters, in response to disclosures of corruption by the Committee on Ethical Practices. After these investigations had concluded, the Executive Council had requested that those unions clean ranks and purge corruption from their bodies. At the time of the convention, only the Allied Industrial Workers Union had done so. Within the months thereafter the AFL-CIO expelled the Teamsters Union, the Bakery and Confection Workers, and the Laundry Workers for failing to take the necessary steps to root out corruption from their ranks.

Having found corruption within its federation of unions, the leadership of the AFL-CIO reaffirmed its "dedication to the principles set forth in the AFL-CIO Constitution," and expressed their "determination to implement those constitutional principles without fear or favor." ${ }^{.16}$ In order to accomplish this, the AFL-CIO passed six resolutions that established their Codes of Ethical Practices. Drawn up by the Ethical Practices Committee, these codes were considered the minimum of conduct required of a member union, and were "intended to be illustrative rather

\footnotetext{
${ }^{14}$ AFL-CIO, AFL-CIO Codes of Ethical Practices (Washington, D.C.: AFL-CIO, 1958), 5.

${ }^{15}$ Ibid., 6.

${ }^{16}$ Ibid., 10.
} 
than all-inclusive in their scope." ${ }^{17}$ The ethical codes of the Committee addressed the issuance of charters; the management of health and welfare funds by union officials; the union's zero tolerance for racketeers, "crooks," communists, and fascists; the potential conflicts of interest of union officials' investment and business dealings; the investment dealings of the unions themselves as an organization; and the democratic processes of the unions.

To protect the integrity of the local union, the AFL-CIO first adopted measures to prevent local charters issued by the national or international union from falling "into the hands of corrupt individuals who have used these charters for their own illicit purposes." Approved by the Executive Council on August 29, 1956, the resolution's primary concern was the use of "a charter ... to invade the jurisdiction of other national or international unions, in the interests only of corruption and dishonest gain, and to cloak with a respectable name a whole range of nefarious and corrupt activities. ${ }^{, 18}$ Second to this concern, the union also acknowledged that local charters could be used "to enter into conspiracies with corrupt employers to prevent, for a price, the genuine organization of workers into legitimate unions, thus depriving these workers of honest collective bargaining agreements." ${ }^{19}$ In order to prevent these actions, the AFL-CIO required that all future member unions be established "by a minimum number of bona fide employees, eligible for membership in the union, [and] within the jurisdiction of the charter."20 Charters could no longer be issued to an individual, and any local union guilty of entering into collusion with employers would have their contracts revoked.

Following this initial action, the Executive Council passed three more ethics codes recommended by the Ethics Committee on January 31, 1957. The Council readily acknowledged

\footnotetext{
${ }^{17}$ Ibid., 12.

${ }^{18}$ Ibid., 18.

${ }^{19}$ Ibid.

${ }^{20}$ Ibid., 20.
} 
that the health and welfare funds established by the union created new responsibilities for its governing representatives, and that the business dealings of those representatives also deserved scrutiny. In order to protect the integrity of the union and its officials, the Council declared that "no union official who already receives full-time pay from his union ... shall receive fees or salaries of any kind from a fund established for the provision of a health, welfare or retirement program.. ${ }^{21}$ The care of such funds by any AFL-CIO representative was considered a part of their duties as a representative of the union, and not a duty that required additional compensation. In addition to this obligation, no union official could "have any compromising personal ties, direct or indirect, with outside agencies such as insurance carriers, brokers, or consultants doing business with the welfare plan." Any official who had such ties that resulted in their "personal advantage or to have accepted fees, inducements, benefits or favors of any kind from any outside agency" would be removed from office. ${ }^{22}$ Similarly, the Council recognized that "a basic ethical principle in the conduct of trade union affairs is that no responsible trade union official should have a personal financial interest which conflicts with the full performance of his fiduciary duties as a workers' representative." ${ }^{23}$ Yet, the Council also recognized that "employee ownership of stock is certainly a fairly common practice in American life" and that there were "special stock purchase plans designed to stimulate such employee investments." Consequently, the Council decided that ownership of such stocks could take place as long as the official's investment was "never ... large enough so as to permit him to exercise any individual influence on the course of a corporate decision. ${ }^{.24}$ Following these parameters, the Council established certain restrictions governing its officials and their business dealings: no trade union

\footnotetext{
${ }^{21}$ Ibid., 23.

${ }^{22}$ Ibid.

${ }^{23}$ Ibid., $29-30$.

${ }^{24}$ Ibid., 32.
} 
official could hold financial interests which created conflict with his fiscal responsibilities as a worker's representative; neither could a union official hold a "substantial business interest" in any company with which the union bargained collectively, or in any companies which were in competition with such companies; and no official could hold an interest in any company that dealt with companies with which the union bargained collectively. The only exceptions to these rules were those companies that were publicly traded - but only if said investments did not present undue influence of corporate decisions.

On the same day the Council issued its codes concerning the proper handling of the union's welfare funds and business dealings, it took even greater steps to limit the presence of "crooks" within the union. It declared that any "person commonly known to be a crook or racketeer ... should not enjoy immunity to prey upon the trade union movement," simply because they had "somehow managed to escape conviction." To this end, any "persons who constitute corrupt influences or practices or who represent or support communist, fascist, or totalitarian agencies ... should [not] hold office of any kind." ${ }^{25}$ Furthermore, any member who had "been convicted of a crime involving moral turpitude offensive to trade union morality" had to be removed from office, a restriction which included any person "commonly known to be a crook or a racketeer preying on the labor movement and its good name for corrupt purposes."26 The Council finalized the Ethics Committee's recommended codes on May $22^{\text {nd }}$ and $23^{\text {rd }}$ of 1957. Returning to the issue of financial propriety in business dealings, the leadership of the AFL-CIO asserted that unions were not meant to serve the same roles as other financial institutions, meaning they were not meant to serve as managers "of funds vested with the duty of

\footnotetext{
${ }^{25}$ Ibid., 28 .

${ }^{26}$ Ibid., 29.
} 
enhancing their value and making distributions." Rather, unions were to serve as "democratic organization[s] with definite social aims and principles." Consequently, the Executive Council and Ethics Committee clarified that union funds simply were meant to be "held in trust for the benefit of membership," and that "increasing the value of the union's funds should never become an objective of such magnitude that it in any way interferes with or obscures the basic function of the union. ${ }^{27}$ To this end, the AFL-CIO adopted similar requirements that it had for individual members in their business dealings. Service providers to the union had to be retained by competitive bids, and the use of union funds could in no way be used for the personal profit of individual members. Nor could the union invest in or loan money to those companies with which it had bargained collectively - but once again, this did not forbid the investment of publicly traded securities, so long as such a stake could not influence the course of corporate decisions. And since unions were democratic organizations, the members of the union were entitled to remain informed of the investments of the union. Furthermore, it was the responsibility of the union members' delegated representatives "to oversee the expenditure of the union's monies so that the members can be guaranteed that funds are expended solely for the purposes for which the organization exists." 28

From the perspective of the AFL-CIO leadership, the ethics codes were meant to preserve and give "effect to the democratic tradition upon which the entire labor movement is based." This was in opposition to the "authoritarian control, whether from within the labor movement or imposed from without by government, [that] is contrary to the spirit, the tradition and the principles ... [of the] movement. ${ }^{, 29}$ Accordingly, as its final code, the union reaffirmed the right

\footnotetext{
${ }^{27}$ Ibid., 35 .

${ }^{28}$ Ibid.

${ }^{29}$ Ibid., 44.
} 
of each union member "to full and free participation in union self-government," which included the right not only to "vote periodically for his local and national officers," but "to stand for and to hold office ... [and] to voice his views as to the method in which the union's affairs should be conducted." ${ }^{30}$ Furthermore, elections of union officials had to be "free, fair and honest," and conducted with "adequate internal safeguards ... to ensure the achievement of that objective.",31 In addition to these rights and safeguards, the union acknowledged that each member deserved fair treatment in the face of union rules and law. Union disciplinary procedures had to be fair and just, following the "essential requirements of due process... [that were the] notice, hearing and judgment on the basis of evidence." 32

Higgins fully supported the union's efforts to work with the McClellan Committee in its stated purpose. Following the events of Riesel's blinding and the creation of the Committee, the presence of corruption within labor was without question, as well as the damage it had committed against the movement as a whole. Consequently, he agreed with a "well known Washington newsletter" which had argued that the "union movement is about to have its worst setback in 20 years." "33 Such a setback was ultimately beneficial for the movement, however. Instead of succumbing to the corruption that had been revealed by the Committee, Higgins believed that the "labor movement will emerge from the present crisis not only cleaner, but stronger and more effective than ever before." This was due to labor's willingness to address the problem of corruption, and to remove it from its ranks. From Higgins's perspective the "labor movement could have dug its own grave, so to speak, if it had opposed or refused to cooperate with the investigation. That would have been disastrous. Fortunately ... George Meany and his

\footnotetext{
${ }^{30}$ Ibid., 46.

${ }^{31}$ Ibid., 47.

${ }^{32}$ Ibid., 46.

${ }^{33}$ George G. Higgins, "Effect of Senate Investigation," The Yardstick, April 8, 1957, ACUA/GGH Papers, Box 346, Folder 2; Unfortunately, Higgins does not name this "Washington newsletter."
} 
associates on the Executive Council of the AFL-CIO are cooperating fully with the staff of the McClellan Committee." ${ }^{34}$ Such cooperation deserved respect by the public at large, and especially from the McClellan Committee itself. Along these lines, Higgins advocated the McClellan Committee's continued role in removing corruption from labor, but tempered his support by reminding the Committee not to venture beyond its stated goals. Higgins feared the possibility that the Committee might put the economic and political policies of the labor movement on trial, rather than investigating the causes and presence of corruption within the movement. As labor's advocate, Higgins continually reminded his audience that the labor movement, as a movement and as an American institution, was not on trial. Its existence and role within the United States was not in question.

Besides this cooperation, Higgins emphasized how the movement had begun proactively to engage the problem independently of that of the Committee. Higgins cited the AFL-CIO's implementation of its Codes of Ethics as a primary example. Such efforts by the union demonstrated its desire to do what was necessary to survive and become stronger as a movement, which was to face "up to their responsibilities in the field of ethical practices." This did not mean that the unions were capable of solving the problem of corruption on their own, however. Such was the reason why he supported the leaders of the AFL-CIO who had admitted "that there are serious abuses in the labor movement," and who "realize... that the job is too big for them" to solve; the job of removing corruption from the ranks of labor was simply too herculean a task. ${ }^{35}$ Consequently, Higgins agreed with the unions' efforts to cooperate with government, which he believed was a necessity if the unions wanted to maintain their autonomy and self-rule.

\footnotetext{
${ }^{34}$ Ibid.

${ }^{35}$ Ibid.
} 
If the labor movement failed to correct the problem at hand, Higgins asserted that the government would act under its own authority and initiative. Self-regulation by the unions was imperative in this regard, especially if they wanted to influence legislation that could affect the movement. By instituting reforms and by working with the McClellan Committee, Higgins believed that unions had a right to expect that "the Senate investigation will not be used as a pretext for enacting legislation which is punitive rather than corrective in nature." This type of action would have been counterproductive to the Committee's efforts. As Higgins described it, punitive "legislation -- i.e., legislation designed to weaken the labor movement or 'to cut it down to size' - is no solution to the problem of racketeering or corruption. On the contrary, it would only make the problem worse. ${ }^{36}$ However, by working with the government in its attempt to redress the problem at hand, labor had every right to expect to be involved in the process.

As Higgins had noted, the AFL-CIO had taken the first step by implementing its Codes of Ethics. The UAW, as a member of the AFL-CIO, followed these guidelines, but went one step further. Under the guidance of its president, Walter Reuther, the UAW created its Public Review Board (PRB) at its 1957 convention. As an organization, the PRB served as an appeals court to its members, and as a resource for UAW workers to report any instances of corruption they might experience. Higgins had his own role to play in the UAW's Public Review Board as well, serving as one of the founding members, and later as its chairman. In this capacity, he helped define its role in relation to the union, especially as he sought to preserve its integrity as an independent appeals court. While this was beneficial for the union and its approach in combating corruption, it also benefited Higgins as well. His experience as a member of the Board was

\footnotetext{
${ }^{36}$ George G. Higgins, “Annual Labor Day Mass" (sermon presented at St. Raphael's Cathedral, Archdiocese of Dubuque, Dubuque, Iowa, September 2, 1957), ACUA/GGH Papers, Box 324, Folder 14, 8.
} 
integral to his understanding of the labor movement, and aided him in his effort to identify the origins of the corruption revealed by the McClellan Committee.

\section{The U.A.W and the Creation of the Public Review Board}

As a member of the AFL-CIO, the United Auto Workers' [UAW] leadership took additional measures in response to the McClellan Committee, while at the same time distancing itself from the majority of unions that could be charged with corruption. At its sixteenth annual convention the UAW created a Public Review Board [PRB] for the union, but argued that the seeds of its creation originated well before that of the McClellan Committee. According to Walter Reuther, president of the union, the discussion of such a review board had taken place behind closed doors during the merger of the AFL and CIO in $1955 .{ }^{37}$ Those unions within the CIO, particularly the UAW, were concerned that public perception of racketeering within the AFL might tarnish all unions of the future AFL-CIO by association. Besides this fear, the UAW also feared that racketeering would persist in the new organization, and that "the UAW would inevitably bear a measure of responsibility in the public mind for misconduct in any union." Consequently, the CIO representatives insisted upon an anti-racketeering clause as part of the constitution of the newly formed AFL-CIO. In addition to this clause, the AFL and CIO representatives also discussed the additional step of creating a review board.

\footnotetext{
${ }^{37}$ The CIO had split from the AFL in 1937 over the issue of granting "unrestricted charters" to unions in industries of mass-production, arguing that there should be no restrictions of union membership according to craft and position within a particular industry. The CIO believed unrestricted organization along industrial lines was critical in its efforts to organize industrial laborers, and that it was only through such "unrestricted charters" that unity could be achieved in the industrial workplace. The AFL was reluctant to issue such charters, since they undercut the union's organizational structure, which was built along craft lines.
} 
According to the UAW's published history of the PRB in "A More Perfect Union ... The UAW Public Review Board: Why, What, How," the Board was "conceived of "primarily as a part of the appeal procedure in our internal trial machinery," but whose concept had later expanded to "cover the broad area of moral and ethical standards." 38 After the merger had taken place, discussion of such a board had waned, but was renewed by Reuther in the months following the creation of the McClellan Committee, culminating in his public request of such a board in March of 1957 just prior to the UAW convention. The UAW history quoted Reuther making this assertion, saying that "more and more ... the labor movement must be prepared to have their stewardship ... subject to review." ${ }^{39}$ Such a request by Reuther and the leadership was not in response to the presence of injustice or corruption within the UAW, however. Instead, it was to create a system that would keep such forces in check, and prevent them from ever developing. By doing so, the union protected itself, and maintained the respect that currently existed between the union's leadership and its rank-and-file. An external governmental body could protect the interests of union members by providing them a place where they "could appeal their grievances against the union and which could act, on its own motion, as censor of the union's moral conduct." 40 Nor was the protection of its members the only benefit, for by acting of their own accord the union defused potentially harmful action by the government. In this sense, Reuther took the same tact as Higgins, arguing that corruption was an issue that the union

\footnotetext{
${ }^{38}$ United Auto Workers, A More Perfect Union... The UAW Public Review Board: Why, What, How (Detroit: U.A.W Publications Department, 1957), ACUA/GGH Papers, Box 243, Folder 8, 3; unfortunately, the authors of this document quoted other UAW documents in the body of their work, but did not cite them. Consequently, there is no sure way to determine which documents they used in its creation.

${ }^{39}$ Ibid., 4.

${ }^{40}$ Ibid., 3.
} 
had to approach voluntarily. If not, Reuther also feared that the government would take action independently of the union, and that such action would harm the movement. ${ }^{41}$

As a result of Reuther's influence and the current climate facing labor, the UAW created the Public Review Board at its $16^{\text {th }}$ convention on April 8, 1957. According to the UAW's published history, the PRB had the authority to make "final and binding decisions" in all cases brought before it by its members or subordinate bodies of the UAW. The Review Board essentially served as its final appeals court, and the union anticipated most cases to be initiated by "individual members who feel they have been unfairly disciplined by their local unions and who have failed to obtain satisfaction upon appeal to the UAW Executive Board.” The Review Board was not limited to individual appeals either. Local unions could also appeal to the Board in instances where they too felt that they had "been unfairly disciplined by the international." The Board also had the authority and "the obligation to deal with 'alleged violations of any AFLCIO ethical practices codes, or any ethical practices codes adopted by the international union."” This authority could circumvent the Executive Council's actions, as it was "authorized to assume jurisdiction over these cases if it is dissatisfied with the executive board's action, even if no appeal is filed." ${ }^{42}$ Finally, the Board served as an outside resource for union members who wished to report ethical violations without notifying their local unions of the charges.

The Review Board did not have any not have any jurisdiction in matters concerning collective bargaining of the UAW, and only had limited recourse in "cases involving grievances arising from the union contract." Besides this restriction, the Board only heard those cases that had been brought first to the Executive Board, and so served as a last resort for the individual

\footnotetext{
${ }^{41}$ Ibid., 4.

${ }^{42}$ Ibid., 5.
} 
union member. Thus, the PRB had "jurisdiction only over charges, previously made to the international executive board, that the grievance was improperly handled because of fraud, discrimination or collusion with management. In other words, the Public Review Board is in no way a super-substitute for local grievance machinery on contract matters." 43

Only one restriction applied to Board membership, which was that no "one under the jurisdiction of the UAW or in any way employed by the union or its subordinate bodies is eligible." No members of the Board could have connections to the union in order to remain impartial in their duties. The UAW president assigned the members of the Board, which had to be approved by both the Executive Board and the convention. Each member's term lasted for one year, after which they had to be reappointed to the position and confirmed once again by the convention. Insofar as the function and governing of the body was concerned, the Review Board was "instructed to make its own rules, hire its own staff and set up its own office, physically apart from any UAW office." 44 The only requirement placed upon the Board in its operations was the condition that it publish in full all decisions made by the Board on an annual basis. These decisions were to be distributed through the official press of the UAW, in addition to being released to the public press as well. Finally, the Executive Council of the union supplied the budget for the Review Board, which included wage and compensation for its members. Each Board member received an annual salary of $\$ 1,000$, and an additional $\$ 200$ for every case in which the member participated. Executive Review Board members each received an additional

\footnotetext{
${ }^{43}$ Ibid.

${ }^{44}$ Ibid., 6.
} 
$\$ 1000$ per year, while the chairman was compensated an additional $\$ 500$ for the added workload the position required. ${ }^{45}$

The PRB set up their office in the David E. Stott Building on 1150 Griswold Avenue, Detroit, Michigan. The original Board consisted of Morris Adler, J. Arthur Hanrahan, Clark Kerr, Wade H. McCree Jr., G. Bromley Oxnam, Edwin Witte, Walter E. Oberer, and of course, George Higgins. The Review Board members consisted of a diverse group of individuals representing a number of faiths, each bringing their own labor background and experiences to the table. Morris Adler was a rabbi for the Shaarey Zedek congregation of Detroit, and served the Board as its first chairman. Adler came to the PRB with experience in labor-management relations, demonstrated by his service to the Detroit mayor's labor-management-citizens' committee. J. Arthur Hanrahan hailed from Ontario, Canada, where he had worked as a magistrate judge for both Windsor and Essex Counties. As a judge he was best known for his work "cleaning up Windsor in the late 1940's," especially "his handling of vice and racketeering cases... [which] led to a sweeping investigation that ended in a police shakeup, the conviction of several corrupt authorities and the retirement of others. ${ }^{, 46}$ Clark Kerr had served as the chancellor of the University of California, where he taught economics and industrial relations. Besides his service as an educator, Kerr had also been a member of the War Labor Board, the Wage Stabilization Board, and had served on numerous Presidential fact-finding boards. Wade H. McCree had served as a commissioner for the Workmen's Compensation Commission prior to becoming a judge on Michigan's Third Circuit. From the perspective of the UAW, his experiences as a commissioner and judge provided the Board with "a youthful, judicious outlook

\footnotetext{
${ }^{45}$ Michael Harrington, Walter E. Oberer, and Jack Stieber, Democracy and Public Review: An Analysis of the UAW Public Review Board (Santa Barbara: Center for the Study of Democratic Institutions, 1960), 11.

${ }^{46}$ United Auto Workers, A More Perfect Union... The UAW Public Review Board: Why, What, How (Detroit:

U.A.W Publications Department, 1957), ACUA/GGH Papers, Box 243, Folder 8, 9.
} 
fortified by a deep interest in inter-racial affairs and practical experiences in a matter vital to workers - workmen's compensation." ${ }^{, 47}$ G. Bromley Oxnam was the Methodist bishop of Washington, D.C., and was "one of the founding officers and as a director of the National Council of Churches.” Besides his responsibilities as a bishop, Oxnam had served as the president of DePauw University, and had written a number of a books focusing on the role of labor and social reform, among them being Labor and Tomorrow's World and Personalities in Social Reform. ${ }^{48}$ Edwin Witte was a professor of economics at the University of Wisconsin, and had also served on Roosevelt's Committee on Economic Security, which had sponsored the Social Security Act. Finally, Walter E. Oberer served as the executive secretary of the Review

\footnotetext{
${ }^{47}$ Ibid., 11.

${ }^{48}$ Within three months of the creation of the PRB, Oxnam took part in the ground-breaking ceremony for the new School of International Studies at American University on June $9^{\text {th }}$, 1957. In his capacity as a Methodist bishop, Oxnam asserted that "since Protestants outnumber Roman Catholics by two to one in the Nation's population, it [was] proper that a school under Protestant auspices should be established where, in the atmosphere of freedom that characterize[d] the Protestant campus, future servants of government, business, labor and the church may be trained." This statement was in direct contrast to Roman Catholic education, particularly that of Georgetown University. Oxnam went on to argue that it was "natural, perhaps even proper ... that students trained by Jesuits in a Jesuit institution should be conditioned favorably to Vatican world policy," and that "this conditioning raise[d] serious questions from the standpoint of the maintenance of democracy." By opening a new School of International Studies, American University had offered "training upon a campus where the unhampered pursuit of truth [was] not only possible but a matter of principle, where religious liberty, together with the basic civil liberties of the democratic order, [could] be examined and espoused, and where men and women of tolerant spirit, abhorrent of bigotry and committed to the free way of life, [could] become equipped to serve the new world, the one world, in the spirit that will preserve and extend liberty to all men everywhere" (G. Bromley Oxnam, "A Date With the World," (excerpts of address given at the Commencement Exercises of The American University, Washington, D.C., June 9, 1957), ACUA/GGH Papers, Box 172, Folder 10). The public statements by Oxnam were immediately picked up by the Catholic press, and Higgins responded privately to Oxnam on June $17^{\text {th }}$. While he was "not particularly sensitive or thin-skinned, even in the area of religious controversy," Higgins admitted that he found Oxnam's "unwarranted criticism of Georgetown University and the Catholic educational system in general deeply offensive." In particular, Higgins questioned whether the two would be able "to cooperate with one another in a spirit of mutual respect and confidence," since Higgins was a "product of the Catholic educational system." Consequently, Oxnam's actions led Higgins to believe that Oxnam did not regard him "as being qualified for membership on a Board which, by definition, [was] dedicated to the defense of civil liberties and to the strengthening of democracy and the free way of life" (George G. Higgins to Bromley Oxnam, correspondence, June 17, 1957, ACUA/GGH Papers, Box 172, Folder 10). Regardless of these personal differences, neither Oxnam nor Higgins resigned from the board over the issue, although tensions remained. In particular, Higgins and Oxnam clashed over Oxnam's association with Protestants and Other Americans United for Separation of Church and State (POAU); the POAU was a national association who sought to prevent government support of religious education. Members of the organization argued that once Catholics gained a majority in the U.S., they would amend the Constitution and end the separation of church and state. The conflict between the two ended with Oxnam's resignation from the board for health reasons on May 1, 1962.
} 
Board. Prior to his work for the Board, Oberer worked as a professor of law at the University of Texas. $^{49}$

\section{Higgins and the PRB: The Value of Democratic Review}

When Higgins joined the Board, he had served as the director of the Social Action Department for three years. His own views concerning the UAW and their attempts to combat corruption were quite clear. Speaking to the sixteenth annual convention, Higgins argued that the union could not separate itself from the larger movement as it sought to protect itself from charges of corruption. Simply put, the UAW could not afford "to approach the problem of racketeering ... as a lily white organization sitting in judgment on the rest of the labor movement." Instead, Higgins reminded those of the UAW that they were a member of the family which was the larger united labor movement, and that "there are faults in every labor union ... even in the UAW." This sense of family was essential during such a period as the McClellan investigation, for if the movement was to survive the storm, then the labor movement as a whole had to take "a family approach to the problem," where "all members of the same trade union family" were "not sitting in judgment of one another but trying to help one another solve a common problem." 50

Higgins reminded the UAW that, as members of the AFL-CIO, they too were bound to the Codes of Ethics as members of this greater family. These Codes of Ethics served to protect the union and its members, and it was for this reason that the "leaders of the AFL-CIO... deserve a great deal of credit for having enacted several Codes of Ethics which will be binding on all of

\footnotetext{
${ }^{49}$ United Auto Workers, A More Perfect Union... The UAW Public Review Board: Why, What, How (Detroit: U.A.W Publications Department, 1957), ACUA/GGH Papers, Box 243, Folder 8, 12 - 13.

${ }^{50}$ United Auto Workers, “Address by Msgr. George G. Higgins," News from the UAW, April 8, 1957, ACUA/GGH Papers, Box 324, Folder 13, $7-8$.
} 
their officers and affiliates under penalty of suspension or expulsion. In this respect they have set an example which might well be followed by all of the other economic organizations in the United States. If these Codes of Ethical Practice are vigorously enforced ... they will undoubtedly be remembered to the credit of the labor movement long after the unsavory abuses which prompted their adoption have been forgotten."

The UAW Review Board complemented these Ethics Codes, and demonstrated its commitment to the cause of not only rooting out corruption from its own ranks, but also creating the structures necessary to prevent it from taking root in the organization. From this perspective, Higgins refuted accusations from Raymond Moley, a former advisor to Franklin D. Roosevelt and editor of Newsweek, who asserted that the Board was simply a public relations act meant to deflect the charges issued by the McClellan Committee. ${ }^{52}$ Given that the PRB had not even heard a case at the time such accusation had been made, the resulting conversation was meaningless. Higgins commented that nothing "could be more futile than to engage in an a priori controversy" concerning the merits and the integrity of the Board, since a record had not been established. As a member of the board, he was "perfectly willing to let the record speak for itself" following its implementation, and only at that time. ${ }^{53}$

Throughout the life of the Board, Higgins understood its role as that of an appeals court, and that its authority did not encompass collective bargaining in any way, shape, or form. He understood the PRB as having "no authority whatsoever to pass judgment on the economic decisions of the U.A.W. In other words, it is not a policy-making Board." While he recognized

\footnotetext{
${ }^{51}$ George G. Higgins, "Sermon for the Annual Labor Day Mass" (sermon delivered at Saint Raphael's Cathedral, Dubuque, Iowa, September 2, 1957), ACUA/GGH Papers, Box 324, Folder 14.

52 "Raymond Moley Dies at 88; Roosevelt Adviser, Author," The Washington Post, February 19, 1973.

${ }^{53}$ George G. Higgins, "First Year of UAW's “Watch Dog Committee,"” The Yardstick, Dec. 29, 1958, ACUA/GGH Papers, Box 346, Folder 8.
} 
that the Review Board had "extraordinarily broad powers," he asserted that its "authority is strictly limited to the adjudication of specific appeals from U.A.W. members and alleged violation of present or future Ethical Practices Codes of the AFL-CIO or the U.A.W." ${ }^{, 54}$ Any suggestion that review boards might one day hold greater authority in the affairs of unions, as Life magazine's editorial board had suggested in its April 22, 1957 issue, was unrealistic; their assertion that "unions may eventually mature enough to let such impartial, public boards" review collective bargaining agreements, was simply an indulgence in fantasy. ${ }^{55}$ Higgins asserted that such a proposal as "so thoroughly impractical that one cannot help but suspect that ... the editors of Life ... have [not] carefully thought it through to its logical conclusions." Fortunately for those editors, Higgins had. The logic of such an argument dictated that "the economic decisions of management as well as of labor ought to be subject to the veto of a board of outside "experts."” No company, let alone union, would be willing to acquiesce to such control, whether that was the UAW or the Luce Publishing Company, of which LIFE was a subsidiary. In Higgins's words, such a development would have required "a first class miracle."

Nor did Higgins believe that there should have been such a development. Rather, he asserted there were "many reasons why labor and management should not transfer their policy-making authority to a board of outside experts." Primary among these reasons was Higgins's belief that such an approach would merely serve to "ignore the problem of labor-management responsibility than to solve it. ${ }^{, 57}$ This was not to say that outside experts did not have a role to play, however. Experts had to be available to labor and management when they were "morally and technically incapable of making the right decisions in the field of economic policy," but such circumstances

\footnotetext{
${ }^{54}$ George G. Higgins, “Authority of Automobile Workers' 'Watchdog Committee,” The Yardstick, April 29, 1957, ACUA/GGH Papers, Box 412, Folder 1.

${ }^{55}$ Life, "Reuther's Watchdog, A Welcome Pup," April 22, 1957, 42.

${ }^{56}$ Ibid.

${ }^{57}$ Ibid.
} 
were rare. Management and labor had to relate to one another without being subject to the influence and review of outside forces when it came to collective bargaining. To suggest and expect otherwise would have been "almost as harmful ... as turning the whole thing over to the government."

The fourth estate wasn't the only body to test Higgins's convictions concerning the constitutional limitations of the PRB either. The leadership of the UAW tested those convictions as well, but in each instance Higgins remained steadfast to the principle that the PRB remain limited in its authority for the benefit of trade democracy. Higgins's first test actually came from the President of the UAW, Walter Reuther. Recalling the event, Higgins claimed that

Walter had invited me to ... his suite at the Statler Hilton Hotel to talk about the role of the Board. At that time, Senator Barry Goldwater ... was carrying on a round-robin vendetta against the UAW. Day after day, on the floor of the Senate, he accused the International of every crime under the sun. Walter was understandably upset ... [and] insisted ... that the Board, on its own initiative, investigate and rule on Goldwater's charges against the Union. ${ }^{59}$

Higgins refused Walter Reuther's request, arguing that such an action was not within the power of the PRB. From Higgins's perspective, "the Board could not and should not take on this openended role," since such an action would have required the Board to exceed "its constitutional limits as an appeals court." When Higgins "realized that Walter not only did not agree ... but, to the contrary, was becoming increasingly adamant in his demand that the Board go beyond its constitutional authority," Higgins felt he "had no alternative but to lay all [his] cards on the table." Not only did Higgins refuse the president of the UAW in his request, but warned him that

\footnotetext{
${ }^{58}$ Ibid.

${ }^{59}$ George G. Higgins to Victor G. Reuther, August 7, 1989, ACUA/GGH Papers, Box 53, Folder 20; Higgins uses the term "International" here to describe the UAW, whose full title is the International Union, United Automobile, Aerospace and Agricultural Implement Workers of America.
} 
"if he insisted on our unilaterally assuming a degree of authority not granted ... in the Constitution," Higgins and his fellow PRB members "would resign immediately." ${ }^{60}$ Fortunately, Walter Reuther dropped the matter, and the issue was settled.

Ironically, Higgins had to make the same case to Reuther's brother Victor, approximately 30 years later. Following Higgins's speech at the UAW's $29^{\text {th }}$ Constitutional Convention in Anaheim, California in June of 1989, Victor Reuther wrote Higgins and questioned his role as the chairman of the PRB, which he considered to be "the 'conscience or watchdog' of UAW internal democracy." Citing Higgins speech at the convention, where he had asserted that democracy is "alive and well in the UAW, "Victor questioned Higgins's judgment in light of charges against the UAW "involving the conduct of concessionary negotiations," as well as "the corporate practice of whipsawing the union's responsibility to challenge it. ${ }^{.61}$ Reminiscent of his argument with Walter Reuther, Higgins's response was clear:

Forgive me for saying so, Victor, but, in my opinion, you completely misunderstand the constitutional role of the Public Review Board and my role as Chairman of the Board. In other words, I think you are asking, even demanding, that the Board unilaterally and arbitrarily exceed its limited constitutional authority by passing judgment on the Union's collective bargaining policies and decisions.

The PRB could not honor such a request, for by "granting an outside board the authority to review in any way the Union's collective bargaining policies and decisions would completely violate both the letter and the spirit of authentic union democracy." If such an action was

\footnotetext{
${ }^{60}$ Ibid.

${ }^{61}$ Victor G. Reuther to George G. Higgins, July 28, 1989, ACUA/GGH Papers, Box 53, Folder 20.
} 
required of the Board and its members, Higgins argued that he would resign rather than "exercise that kind of undemocratic authority."62

While Higgins fought to maintain the boundaries set by the PRB's constitution in its role as an appeals court, he also believed that the PRB served a greater purpose than what was outlined in its constitution. Higgins argued that the "very fact of the PRB's existence serves as a check on potential abuse of power," and helped preserve the union's democratic principles. ${ }^{63}$ In particular it provided its members with an outlet to express their democratic impulses, and a final opportunity to insure their voices were heard. As a member of the PRB, Higgins was encouraged by the "number of complaints ... brought in the name of conscience... complaints in which the local member is not seeking any monetary reward or personal benefit for himself." By such actions the individual union member saw "himself as a conscience of his Union. He believes the Union is not measuring up to its past standards, and wants the Public Review Board to do something about it." ${ }^{\text {"64 }}$ It was the efforts of these members that encouraged Higgins's belief in the trade movement, for it demonstrated the personal investment the union's members had made for the cause. By providing an avenue of recourse for its members, the union provided an integral component for the maintenance of internal union democracy, which was that each person within the movement believed in their role as member of it. These appellants, no matter how petty their complaints may have been, were "an index of how important the Union is in the lives of its members." 65

\footnotetext{
${ }^{62}$ George G. Higgins to Victor G. Reuther, August 7, 1989, ACUA/GGH Papers, Box 53, Folder 20.

${ }^{63}$ George G. Higgins, "Address for the Twenty-First Constitutional Convention of the United Auto Workers" (address presented in Los Angeles, California, May 15, 1977), ACUA/GGH Papers, Box 333, Folder 11, 6.

${ }^{64}$ Ibid., 5 .

65 Ibid.
} 
It was for this very reason that Higgins advocated the adoption of public review boards by all the major unions. As far as Higgins was concerned, the record of the PRB had proved its value to the labor movement by encouraging a greater form of participation by its members, as well as providing an outside organization where all members could be held accountable for their actions. Higgins readily acknowledged that such an organization required full autonomy and independence from a union's leadership, which in the case of the PRB had been well established. Some ten years following the creation of the Board, Higgins believed the "record shows that the PRB, on the one hand, has called the shots as it saw them and the UAW, on the other hand, has scrupulously respected the Board's completely autonomous and independent status and has never in any way attempted, either directly or indirectly, to influence the Board's decisions. ${ }^{.66} \mathrm{By}$ doing so, the PRB stood in stark contrast against its initial detractors who had charged that the Board was a public relations stunt meant to deflect the charges of the McClellan Committee. More so, the findings of the Review Board refuted the allegations that the UAW and its leadership were corrupt. Such had been the case, and had remained so, since the first annual report was published in 1959. In that report, the Board found "that 'the UAW is free from corruption and gross perversion of ... democratic procedures,"” and that "none of the cases which the Board has dealt with ... 'reflect evils in the basic structure of the Union or the conduct of its affairs." Complementing this finding, Higgins charged that the record also demonstrated "that both the leaders and individual members of the UAW who were directly involved in the various cases decided by the Board conducted themselves with admirable dignity and restraint and that their cooperation with the Board left nothing to be desired. ${ }^{, 67}$ It was for this reason that Higgins agreed with his departed friend, the first chairman of the Board, Rabbi Adler, when he

\footnotetext{
${ }^{66}$ George G. Higgins, "Address at the $20^{\text {th }}$ Constitutional Convention of the United Auto Workers (AFL-CIO)" (address given in Long Beach, California, May 1, 1966), ACUA/GGH Papers, Box 327, Folder 6, 2. ${ }^{67}$ Ibid.
} 
said in the first annual report "that "the creation of the Public Review Board reveals the high degree of stability, responsibility and moral health which American labor possesses and indicates that it has the capacity for self-discipline to enable it increasingly to remove the deficiencies and inequities from which no large organization is entirely free." ${ }^{\prime 68}$

\section{The Source of Corruption: The Spiritual Malaise of the Rank-and-File}

The establishment of the AFL-CIO's Codes of Ethics, and the creation of the Public Review Board by the UAW, only affirmed Higgins's belief that the leadership of the movement was sound. By implementing codes of ethics, and in the case of the UAW, an external review organization, the leaders of labor had demonstrated their devotion to the democratic elements of the labor movement. Higgins refused to "buy for a minute the facile easy explanation that the problems of the labor movement are due to the leadership that the labor movement has." It simply had to come from a different source. Consequently, while the labor movement was "confronted with a very serious crisis - perhaps the most serious crisis in its entire history," Higgins remained confident its leadership was not a part of the problem that labor faced. In his words, "the leadership of the American labor movement by and large, is pretty good. It is probably a little better than the rank-and-file deserve." ${ }^{69}$ With this acknowledgement, Higgins turned his eye to where he believed the root cause of corruption lay -the rank-and-file.

If anything, Higgins believed the McClellan Committee was a distraction from the real problem at hand. To be certain, corruption existed within the unions, which both the Committee

\footnotetext{
${ }^{68}$ Ibid., 3.

${ }^{69}$ United Auto Workers, “Address by Msgr. George G. Higgins," News from the UAW, April 8, 1957, ACUA/GGH Papers, Box 324, Folder 13, $9-10$.
} 
and the Ethical Practices Committee of the AFL-CIO had discovered. The individuals guilty of such crimes against the labor movement were only the "surface symptoms of a deeper disease in the labor movement," however. Such individuals were "merely symbols ... of a decline in moral and spiritual values on the part of the rank and file." It was this moral and spiritual decline which had allowed corruption to take root, and to grow within the movement. Consequently, the real danger the labor movement faced was the rank-and-file's growing apathy. Evidence for such a claim lay in their "lack of interest in union affairs and an unwillingness to relate the principles of religion and morality to the everyday problems of the movement." ${ }^{, 70}$ The actions of leadership, ranging from the reforms of the AFL-CIO to the creation of the PRB, made little difference if the rank-and-file were unwilling to take advantage of the democratic opportunities they provided. These codes of ethics and organizations of internal justice mattered little if the movement's own members weren't willing to report and to root out the corruption they witnessed as members of a union. This was the reason why Higgins appreciated any and all appeals to the PRB while he was a member, whether that was an election complaint or some other ethical charge. For when Higgins saw such a complaint, he made a mental "note in the back of [his] mind that this guy cared. He or she really wanted that job and was willing to fight for it." Such action demonstrated that the individual was invested in the labor movement; it was the opposite of apathy. From Higgins's perspective then, it was the rank-and-file "who turned suddenly quiet that one should be worried about," and it was the "member that doesn't vote at all as opposed to the member who is allegedly stuffing the ballot box" that should have caused concern. ${ }^{71}$ Unfortunately for the movement, more and more members seemed to have this mindset.

\footnotetext{
${ }^{70}$ Ibid., 3.

${ }^{71}$ George G. Higgins, "Address for the Twenty-First Constitutional Convention of the United Auto Workers" (address presented in Los Angeles, California, May 15, 1977), ACUA/GGH Papers, Box 333, Folder 11, 3.
} 
Higgins believed that the current generation of the rank and file had lost their way, and had forgotten the spiritual origins of the labor movement. Generations had passed since labor's inception, and the sacrifices that the labor leaders and the rank-and-file of yesteryear had made were far removed from the workers of the day. The rank-and-file had become complacent; they had not made the sacrifices their predecessors had. The Taft-Hartley Act complicated the situation as well. While union workers paid their dues, and shouldered the responsibilities that union membership required, non-union members reaped the same benefits earned by the union members' efforts towards economic justice. For Higgins, the impact of the law, including its prohibition of the closed shop, and its enabling of right-to-work laws by state legislatures, meant that the labor movement had to investigate other avenues to promote a greater participation and interest of its members. The movement had to motivate the rank-and-file. After all,

Congressional investigations, Ethical Practices Committees, Public Review Boards -these are all to the good, but, at best, they are only a partial solution to the moral and spiritual crisis confronting the labor movement.... They are useful and perhaps even necessary instruments or means of implementing a minimum code of trade union morality. But they accomplish very little unless the rank-and-file are convinced that they have a moral obligation to assume their full share of responsibility for the conduct of union affairs. $^{72}$

The following chapter will investigate Higgins' approach to solving the problem of the rank-and-file's growing apathy. If, as Higgins believed it to be the case, the health of the labor movement rested in the soul of the individual worker, then that worker had to believe in the movement and invest in it. In order to bring about such a response, Higgins sought not only to remind the rank-and-file of their spiritual roots, but to renew their spiritual identity. In this effort

\footnotetext{
${ }^{72}$ United Auto Workers, “Address by Msgr. George G. Higgins," News from the UAW, April 8, 1957, ACUA/GGH Papers, Box 324, Folder 13, 4.
} 
he made a special appeal to the Catholics of the rank-and-file in the labor movement, whom he believed represented the majority of the workers. Returning to his own roots, Higgins presented a theology based on the liturgical movement of Virgil Michel. Central to this theology was the Mass and the sacrifice it entailed, for it was the Mass that promoted "a sense of fellowship of all in relation to all," and was the "primary source of asceticism and penance without which there can be no conversion from human selfishness of sin and no redemption of individuals or the temporal order."73 The spiritual values of the labor movement and those of the Mass were the same. It would provide the spiritual motivation necessary to end the apathy that the rank-and-file expressed.

\footnotetext{
${ }^{73}$ George G. Higgins, "The Mass and the Political Order" (address presented at the $16^{\text {th }}$ National Liturgical Week in Worcester, MA, Aug. 24, 1955), ACUA/GGH Papers, Box 324, Folder 4, 135.
} 


\title{
Chapter 5
}

\section{A Return to Taft-Hartley: Higgins's Introduction of the Liturgical Movement to Motivate the Rank-And-File}

\begin{abstract}
Nevertheless, we have not yet formulated a theory of democracy that includes these organizations [the voluntary associations that mediate between the individual and the state], that makes them indispensable to free, representative government... The liturgy will not supply such a theory, but it can spiritually prepare the Catholics of the United States to take the lead in developing such a theory as one more step forward in mankind's quest for a more perfect community in the political and economic order. The liturgy, especially the Massliturgy, is the great source of those virtues of justice and charity necessary in the quest for community.
\end{abstract}

- $\quad$ Rev. George G. Higgins, The Yardstick, May 15, 1961

\section{$\phi$}

For Higgins, the presence of corruption within the labor movement was merely a distraction to the larger issue that Taft-Hartley promoted, which was its moral and spiritual decline. He believed that its restrictions against the closed shop had fostered apathy within the unions, which had led to a decline in both membership and participation within the unions. This belief was substantiated by such unions as the AFL-CIO, who in its Codes of Ethical Practices had asserted that the "provisions of the Taft-Hartley Act have substantially frustrated previously successful efforts by unions to ensure maximum attendance and participation by the membership in union meetings and affairs." ${ }^{1}$ And while the AFL-CIO asserted that the answer to its dilemma was the greater "exercise of rights presently recognized and accorded" to its members, Higgins believed that such action by the unions, while helpful, was inadequate. ${ }^{2}$ Instead, he argued that the labor movement needed to remind the rank-and-file of its spiritual origins, and to instill in

\footnotetext{
${ }^{1}$ AFL-CIO, AFL-CIO Codes of Ethical Practices (Washington, D.C.: AFL-CIO, 1958), 45.

${ }^{2}$ Ibid.
} 
them a response in kind. Consequently, he set about developing a theological basis to promote the renewal among the rank-and-file.

By encouraging the rank-and-file's spiritual renewal, Higgins believed that the labor movement could still accomplish what Taft-Hartley tried to prevent—-the comprehensive organization of the working class. Not only would this benefit the health of the movement and serve to prevent the corruption which had been revealed by the McClellan Committee, but it also helped the Department accomplish its own goal, which remained the implementation of Pius XI's Industry Council Plan.

\section{Higgins as Director: The Department's Continued Stance on Taft-Hartley}

As director of the Social Action Department, Higgins recognized that the fruits of the TaftHartley bill remained one of the biggest obstacles he faced in his effort to implement the Industry Council Plan. In particular, the act's right-to-work laws hindered its enactment by restricting union establishment and development in industry. Higgins defined the right-to-work law "as an act which forbids an employer to require an employee to be a member of a union as a condition

for obtaining or retaining employment." ${ }^{3}$ While such legislation may have seemed to protect the rights of workers who did not wish to join a union, Higgins argued that the law's true purpose was to restrict labor to the benefit of management. His proof for such an assertion rested in the fact that the proponents of Taft-Hartley were "claiming for workers a freedom which the latter... do not desire. Under the Labor-Management Relations Act (Taft-Hartley Act), a union might ask for a union shop, or other forms of security, only after a majority of the affected workers had

\footnotetext{
${ }^{3}$ George G. Higgins, Testimony for the Special Subcommittee on Labor, on June 3, 1965 to the House Committee on Labor and Education, Washington, D.C., ACUA/GGH Papers, Box 327, Folder 3, 1.
} 
approved such a request in a federally conducted secret election. In nearly fifty-thousand such elections, the union shop was approved in $97 \%$ of the cases. Ninety-one percent of the workers involved favored the union shop. So uniform was the response, in fact, that the requirement for a vote was dropped from the law in 1951." ${ }^{\circ 4}$ Consequently, Higgins believed that right-to-work laws outlawed "a traditional form of union-management relationship sanctioned" since the passing of the National Labor Relations Act in $1935 .^{5}$

The rights of the minority did not outweigh those of the majority when it came to the union shop; Higgins believed that the majority had "the right to demand that the minority conform" to compulsory union membership. Echoing the argument set forth by Pius XI in Quadragesimo Anno, Higgins argued that man was "more than an individual... he is also a member of society. Such is his nature as God made him. For this reason, the rules for harmonious social living can be binding laws, not merely optional regulations. Thus, as members of civil society, we must obey laws, pay taxes, and fulfill our duties as citizens. As members of the familial society, we have rights and duties, whether we be parents or children. Likewise, the common good of industrial society may demand that individuals conform to rules laid down for the good of all."6

Such was the state of Higgins' attitude towards the Taft-Hartley Act when he assumed his duties as director of the Social Action Department in 1954. The 1955 Annual Report by the SAD confirmed this, arguing that the "past year was a mixture of progress and retrogression in the field of labor-management relations. The most disturbing item on the debit side of the ledger was the enactment in several states of so-called right-to-work laws designed ostensibly to protect the

\footnotetext{
${ }^{4}$ Ibid., 4.

${ }^{5}$ Ibid., 2.

${ }^{6}$ Ibid., 5.
} 
worker's freedom to join or not join a union, but calculated, in effect, to weaken trade unionism... and to hinder rather than encourage the development of sound collective bargaining." ${ }^{7}$ As director, Higgins believed the goal of the department was the establishment of "a society permeated with the ideals of justice and charity, directed toward the aim of restoring all things in Christ." Thus, the Social Action Department sought "to influence the thinking of individuals, and their conduct," but even more so, hoped to inspire others "to seek a form of social organization which, by itself, conduces to virtue and Christian living."

As has been demonstrated in previous chapters, the Industry Council Plan stood as a constant in the department's attempts to bring about such a society in the United States. It remained so throughout Higgins' tenure as director. However, this is not to say that means of instituting the Industry Council Plan did not change during Higgins' directorship of the department. The implementation of the plan changed considerably, as Higgins adapted it in response to the discord the Taft-Hartley Act had created in the labor movement since its passing in 1947. Taft-Hartley's restrictions against compulsory union membership created problems for the department as it stood in direct contradiction to their aims. If the Industrial Council Plan were ever to be implemented, then union membership was the duty and obligation of every worker.

Particularly troubling was the effect Taft-Hartley produced in the life of the everyday worker. By "protecting" the rights of workers to decline union membership, the same right-towork laws promoted apathy within the unions' rank-and-file. Non-union workers did not have the same demands as card-carrying members, nor did they have the same responsibilities, and yet they received the same benefits for which the union had fought. At the same time, the labor

\footnotetext{
${ }^{7}$ National Catholic Welfare Conference, "Annual Report of the Department of Social Action, Washington, D.C., 1955," ACUA, Reading Room Stacks, 6.

${ }^{8}$ George G. Higgins, "N.C.W.C Social Action Department," ACUA/GGH Papers, Box 189, Folder 8, 3.
} 
movement had come into its own in the American landscape. With the days of its formation long behind it, current union membership had little reference to the demands and ethos of the movement itself. Increasingly, Higgins understood that the greatest threat to union strength came from within, as their own members began to care less and less about the movement, and as they lost touch with the sacrifices their forefathers had made. This rank-and-file apathy, along with the impediment towards organization which the right-to-work laws created, threatened the Industry Council Plan as a whole, since American secular unions were essential towards its creation and implementation.

Higgins recognized that if the Industry Council Plan were to be fully implemented in the United States, then the laity of the American Catholic Church had to take on a greater and more active role in its creation. The seeds of this realization may be seen in his assessment of the department, written within a year of his becoming director. After reviewing the work of the previous year, Higgins marked the National Catholic Social Action Conference, held by the SAD in Cleveland, Ohio, September $7-9,1955$, as the turning point for lay social action in the United States. It was at this conference that "it was generally agreed... that the time has come, if not to de-emphasize the role of the clergy, at least to give greater attention to the role of the laity in the social apostolate." Believing this to be the case, Higgins supported the effort to "strive in a special way 'to train and send out zealous lay apostles who will work for personal and institutional reform." ${ }^{9}$ In the same breath, Higgins also realized that training alone was not enough for these lay apostles. The laity of the Church needed a reason to conduct their work, specifically a theological basis for the social reconstruction advocated by the encyclicals.

\footnotetext{
${ }^{9}$ Ibid., 11.
} 
Fortunately for Higgins and the Social Action Department, Virgil Michel's liturgical movement of the late 1920s and 30s provided such a theological structure.

\section{The Influence of the Liturgical Movement - From Virgil Michel to Reynold Hillenbrand to George Higgins}

Born in 1890 in Saint Paul, Minnesota, Virgil Michel entered the Benedictine novitiate at St. John's Abbey in Collegeville, Minnesota in 1909, and was ordained in 1916. He completed his doctorate in English at the Catholic University of America in 1918, examining the works of Orrestes Brownson, and his belief that literature served "as a powerful agent in moulding the thought of readers. ${ }^{, 10}$ Michel's liturgical development did not fully mature until six years later, when he traveled the European continent from February of 1924 to August of 1925. It was during this trip that he met Dom Lambert Beauduin, who was then serving as the professor of fundamental theology at Sant'Anselmo, the International Benedictine University in Rome. ${ }^{11}$ By taking Michel under his wing, Beauduin exposed him to the European liturgical movement, a movement which Michel would bring back with him to the States.

Beauduin believed that salvation rested in the practice of the liturgy, which unified all members as the Mystical Body of Christ. In truth the liturgical movement espoused by Beauduin, and later by Michel in the States, presented the Church as the Mystical Body of Christ, whose life and presence were defined in the Church by the liturgy. Such was the extent of Beauduin's influence that upon his return to the States Michel founded the journal Orates Frates and the

\footnotetext{
${ }^{10}$ Virgil Michel, "Critical Principles of Orestes A. Brownson" (PhD diss., Catholic University of America, 1918), 102, quoted in Paul B. Marx, O.S.B., Virgil Michel and the Liturgical Movement (Collegeville: The Liturgical Press, 1957), 13.

${ }^{11}$ Geoffrey Wainwright and Karen Westerfield Tucker, The Oxford History of Christian Worship (New York: Oxford University Press, 2006), 702.
} 
Liturgical Press. ${ }^{12}$ The journal's name originated from the priest's prayer at the Mass inviting the faithful to participate in the blessing of the gifts, calling all members of the Church to "Pray, brethren, that our sacrifice might be acceptable to God, the almighty Father," and to which the members of the Church respond in kind, "May the Lord accept the sacrifice at your hands for the praise and glory of his name, for our good and the good of all his holy Church." Michel had chosen the name in attempt to foster a greater participation in the sacrifice of the Mass, as well as "a deeper understanding and wider participation in the official prayer of the Church."13 Within three short years, it appeared that he had done so. Orates Frates reached twenty-six countries and was considered the official voice of the liturgical movement.

Michel believed that it was "above all in the official liturgical acts of the Church that Christ lives and acts," and that it was through the "liturgy that the redemption of Christ... is extended over all time for the constant glory of God and the salvation of souls." In particular, Michel stressed the sacrifice of the Eucharist as central to the liturgical life of the Church, for it was this communal act that Christ "continues to offer to God His own all-sufficient Sacrifice of praise and atonement. ${ }^{" 14}$ The communal sacrifice allowed all members of the Church to share in the divinity of Christ as well. Michel believed that the Mass was communal worship at its best, whereby the community offered itself in union with Christ as the "Sacrifice of the Mystical Body, offered by all 'by the hands of the priest' and in union with Him [Christ]." As a result, the Mass took center stage in the life of all Catholics. From Michel's theological point of view, it was

\footnotetext{
12 Orates Frates would later change its title to Worship in 1951.

${ }^{13}$ Virgil Michel to Alcuin Deutsch, April 3, 1925, quoted in Paul B. Marx, O.S.B., Virgil Michel and the Liturgical Movement (Collegeville: The Liturgical Press, 1957), 39.

${ }^{14}$ Virgil Michel, Our Life in Christ (Collegeville: The Liturgical Press, 1939), 50, quoted in Paul B. Marx, O.S.B., Virgil Michel and the Liturgical Movement (Collegeville: The Liturgical Press, 1957), 51.
} 
above all the general action of the Mass that should ... inspire us ... There every action of our lives must be centered, and thence it must derive its inspiration. If we can learn again to offer our whole selves consciously on the altar of Christ's own sacrifice, our body and our soul, our actions and all the material possessions we have; if we can realize better that this offering is made in union with all our brethren, and is made by each for all and by all for each; and if we can learn to grasp by growing degrees the sublimer truth that this offering of ours is merged with the very sacrifice of Christ Himself - then, indeed shall we be better able to assign the material goods their rightful place in human life and no more; and then too, shall we understand better that all we are and have is most solemnly dedicated to the service of God, to Him directly, as well as to the service of Him in all our fellow men. ${ }^{15}$

Michel stressed the role of the community in conjunction with that of the priest in the offering of the Eucharist. The nature of the Mass required the priest, since the priest acted in the person of Christ and served as the leader of the community in the act of sacrifice. At the same time however, the lay community of the Church participated alongside the priest in his sacrifice. In this sense, the sacrifice of the Mass was offered by all by the hands of the priest, and was truly a communal act that required the participation of the laity. Michel believed that it was for this reason that the Orates Frates prayer described the act as "our sacrifice," and the community responded by asking God to accept it at the priest's hands. In this sense all members of the church belonged to the priesthood of Christ, but not all shared in that priesthood in the same way. In speaking of terms of the Mystical Body, different members of the Church had different roles and functions within it, much in the same way that different organs and limbs of a physical body have different functions, but still operate towards the same goal, which is the health of the whole.

By promoting the understanding that all members of the Church shared in the Mystical Body of Christ, Michel espoused a communal vision of the church which required the

\footnotetext{
${ }^{15}$ Virgil Michel, “Apostolate,” Orates Frates XI (1937): 323 - 324, quoted in Paul B. Marx, O.S.B., Virgil Michel and the Liturgical Movement (Collegeville: The Liturgical Press, 1957), 52 - 53.
} 
participation of all its members. This participation meant there was no spiritual isolation within the Church, since Michel believed that "all members [of the Church] are co-responsible for the spiritual growth of the entire Mystical Body."16 As a result, the meaning of sin changed for Michel as well, and became much more communal and social in nature. Michel believed that every action of the individual affected the community as a whole. Unfortunately, from Michel's perspective, individualism had become the norm in modern society, having replaced the communal identity that Christians had shared during the medieval period of the Church. Consequently, the role of the lay Church member was to return this communal identity to the world surrounding them, which demanded a devotion to social justice.

The Great Depression of the 1930s only amplified Michel's belief that the world had lost its way. The evils of the depression were the fruits of the extreme individualism Michel hoped to remedy, one whose solution lay in the return to a society founded in community. Michel argued that legislation and government action would prove ineffective towards such a goal however, since the ills present in the world were merely a reflection of the spiritual deficiency of its citizens. For Michel, social reconstruction depended upon the reform of the individual first. This was not to say that social institutions and society were not in need of reform, but rather individuals had to reform themselves before any social change had a chance of succeeding on the institutional level. The most effective way of instituting individual change rested in the liturgy and the communion which the Mass as sacrifice offered. It rested in the realization that such a society already existed in its most perfect form as the expression of community found in the Eucharist.

\footnotetext{
${ }^{16}$ Virgil Michel, "Liturgy and the Catholic Life," unpublished manuscript, 139, quoted in Paul B. Marx, O.S.B., Virgil Michel and the Liturgical Movement (Collegeville: The Liturgical Press, 1957), 54.
} 
By advocating such an understanding of the Church, particularly the new roles of the laity and the clergy in its liturgical life, Michel challenged the traditional relationship between the clergy and the laity. The laity now shared in the priesthood of Christ, and had a specific role in the temporal world that existed outside the Church. In terms of the liturgy, lay Catholics had a social responsibility outside the weekly presence of Christ found in the Mass. In order to fully participate in the life of the Church, its lay members were responsible for bringing Christ to the world around them. For the laity, this required a life of social justice, especially in the work place. Consequently, Michel advocated an understanding of Christ that moved his presence outside the tabernacle of the local Church, and into the minds, hearts, and personhood of the religious community. Furthermore, such a presence was not limited to the religious community alone, but was expected to become a part of society at large. Followers of the liturgical movement expected to bring about social change through their efforts outside the Church and its religious organizations. Consequently, Michel's liturgical movement challenged the traditional understanding of Catholic Action, which had been previously understood to reside solely under the direction of the hierarchy through membership of sanctioned Church organizations. Instead, Michel asked the faithful to change society by practicing their faith in their secular lives, which included the work place. According to Michel, this was their right as members of the Church, since the affairs of the secular world was a part of their station as the laity. Ultimately, this meant that only they had the competence to bring about such change in the social order.

Unquestionably, George Higgins was well acquainted with Michel's liturgical movement prior to his time at the Social Action Department. Michel's liturgical theology was a strong component of Msgr. Reynold Hillenbrand's curriculum as rector of St. Mary's Seminary in Mundelein, Illinois, which Higgins attended from 1934 to 1940. While serving as rector, 
Hillenbrand pushed an agenda of liturgical reform, particularly in regard to the Mass, much in the same way that Michel had. From Hillenbrand's perspective, it was "quite useless to talk about the details of the Mass and the historical elements that enter into the Mass" without proper education of "the divine life and the Mystical Body." Consequently, soon after his assumption of duties as rector of the seminary, he completely reorganized the liturgy course required of all seminarians. His course on the liturgy emphasized that "people need what Pius X advocated, an active participation in the Mass and in the divine office. Only the doctrines of the supernatural life and the Mystical Body... will give both priests and the laity the proper background for active participation. ${ }^{17}$ Continuing this theme, Hillenbrand also taught his students that the Eucharist functioned as "the effective presentation of the Mystical Body" and that the liturgical year was "the reproduction of the life of the Head in the lives of the members of the Mystical Body."18 Thus, for Hillenbrand, and for those students influenced by him, the Mass served to reinforce the corporate nature of the Church and of humanity.

Nor was Reynold Hillenbrand the only liturgical influence on Higgins. After all, Higgins served as the columnist of The Yardstick, a post handed to him by his predecessor McGowan. As the author of The Yardstick, Higgins measured the social issues of the day against "the yardstick of papal teaching," and none more readily so than that which the Church offered through its encyclicals. Consequently, Higgins would have been readily familiar with Pope Pius XII's encyclicals Mystici Corporis and Mediator Dei, issued on June 29, 1943 and November 20, 1947 respectively. Mystici Corporis affirmed the nature of the Church as the Mystical Body of Christ, while Mediator Dei considered the expression of that identity in the liturgy. Both encyclicals

\footnotetext{
${ }^{17}$ Robert Tuzik, "The Contribution of Msgr. Reynold Hillenbrand (1905 - 1979) to the liturgical movement in the United States: Influences and Development" (PhD diss., Notre Dame University, 1989), 42.

${ }^{18}$ Ibid., 47.
} 
served to validate the liturgical movement promoted by Virgil Michel, especially that of Mediator Dei, which was the first official statement of the Church on the theology of the liturgy. ${ }^{19}$ The encyclical justified much of what Virgil Michel had promoted, particularly his assertion that the Mass served as the public worship of the whole of the Mystical Body, which was the Church. In this sense, the offering of the Mass was the offering of the entire faithful as the Mystical Body. All members of the Church participated in this offering, and so greater participation was required by the laity in the liturgy. Nor did Pius XII stop there, but also condemned those who were indifferent to the Mass.

In regard to Higgins, these two encyclicals were vitally important for the validation they provided. Throughout his years at the Social Action Department, studied and applied the social encyclicals of the Church. In this regard, the encyclicals of Pius XII validated the training he had received by Reynold Hillenbrand, and would later serve him again as he applied those teachings to the social issues he faced. In this particular instance, Higgins departed from the social encyclicals which had served him in the formation of the Industry Council Plan, Rerum Novarum and Quadragesimo Anno. Facing the apathy that Taft-Hartley had created, Higgins would apply Virgil Michel's liturgical movement to the problem at hand, once again applying papal teaching to the social issues of his day.

\section{Labor's Crisis: Its Departure from the Spiritual Origins of the American Labor Movement}

When reviewing Higgins's early Yardstick columns, it becomes clear that Higgins wrestled with the lack of a theological foundation for the laity when it came to their work

\footnotetext{
${ }^{19}$ It should be noted that Mediator Dei did condemn the excesses of the liturgical movement, but such correction is minimal in comparison to the encyclical as a whole. The document itself may be divided into six sections: 1) introduction; 2) the nature and origin of the liturgy; 3) the Eucharist; 4) the Divine Office; 5) the Liturgical Year; and 6) pastoral suggestions for the hierarchy.
} 
towards a Christian social order. He perceived the labor movement as having a religious foundation, but had not yet formulated a theology that incorporated its religious aspects into a wider Catholic framework. His January 15, 1950 Yardstick column demonstrated this readily. The column, simply titled "Voluntarism," defined the term as "American labor's long-standing tradition of fending for itself and of accomplishing its major objectives by 'voluntary' action -collective bargaining, principally -- instead of resorting to governmental intervention." This definition was opposed to the definition recently published by the U.S. Department of Labor's Bureau of Statistics, which defined voluntarism "as follows: 'the self-imposition or acceptance by labor and management of restrictions on their freedom of action in industrial relations." Higgins took exception to this definition for it relied upon the individual's sense of citizenship to accept such restrictions on behalf of the government. Simply put, it relied too heavily upon patriotic principles in order to achieve its goals. The demands of such a voluntarism were "almost too much for human nature. Selfishness and greed can be stifled or subdued temporarily by the natural virtue of patriotism. But, sooner or later, as the emergency drags on, patriotism, if unsupported by religious motives and the grace of God, will inevitably begin to peter out. When that happens, voluntarism will have to be supplemented proportionately by compulsory governmental restrictions." Ultimately, the type of voluntarism defined by the government foundered without religious principles. Instead, if voluntarism were truly to succeed, Higgins asserted that it required "the art of personal sacrifice for the love of God and neighbor," which meant "prayer and penance. ${ }^{20}$ From Higgins's vantage, voluntarism and the labor movement required a supernatural impetus.

\footnotetext{
${ }^{20}$ George G. Higgins, "Voluntarism," The Yardstick, Jan. 15, 1950, ACUA/GGH Papers, Box 344, Folder 13.
} 
Fortunately for the United States and its citizens, the foundation of the labor movement had not relied solely upon such secular principles. Rather, its foundation was religious in its tone and character. ${ }^{21}$ The proof for such an assertion could be readily interpreted through the date of Labor Day in the United States, which held special significance for Higgins. Higgins pointed out that the American Labor Day was not held on the first of May, but rather the first Monday of September. The fact that it did so, "instead of on the traditionally Marxist first of May... is very significant. It symbolizes - and from the very beginning was intended to symbolize - the American labor movement's fundamentally wholesome attitude with regard to labormanagement relations. Whereas the Marxist founders of the European May day subscribed to the philosophy of class struggle and were bitterly opposed to religion, the founders of our Labor Day in this country believed in the philosophy of labor-management cooperation and, from the very beginning, encouraged their constituents to cooperate with the churches in giving a religious tone to the observance of labor's national holiday." ${ }^{22}$ According to Higgins, the origins of the labor movement in America supported this point of view as well. The founders of the movement "never regarded it as a purely secular holiday. As early as 1909, and at regular intervals thereafter, the American Federation of Labor designated the Sunday preceding Labor Day as Labor Sunday and requested its affiliated unions to cooperate with the churches in securing attendance at special services devoted to the subject of religion-and-labor." ${ }^{23}$ This decision to include the churches was no accident. Samuel Gompers, founder of the American Federation of Labor in 1886, "had to decide whether the American labor movement should be a Socialist

\footnotetext{
${ }^{21}$ According to Higgins, it was fortunate that the labor movement rested upon religious principles. If it had not, he believed the American Catholic Church would never have aligned with labor's cause, and that Cardinal James Gibbons would not have come to the aid of the Knights of Labor and have prevented its condemnation.

${ }^{22}$ George G. Higgins, sermon preached at the Annual Labor Day Mass, Shrine of the Sacred Heart, Washington, D.C., September 7, 1964, ACUA/GGH Papers, Box 326, Folder 11, 2.

${ }^{23}$ George G. Higgins, sermon preached at the Annual Diocesan Labor-Management Conference Mass, Gesu Church, Miami, Florida, August 30, 1962, ACUA/GGH Papers, Box 326 Folder 3, 5.
} 
movement or a totally new kind of labor movement -- an American movement -- neutral in the very best sense of the word, but guided by the light of Judaeo-Christian, social ethics. It was a tug of war, but Gompers... was a man of common sense and good practical judgment. He abandoned the Socialist philosophy which he had studied so intensively as an immigrant cigar maker from the slums of London and established his new federation as a neutral, non-Socialist organization." 24

Gompers himself espoused the ideals of sacrifice that reinforced the religious character of the movement. ${ }^{25}$ Gompers, at least according to the autobiography that Higgins promoted, initially refused the office of the president of the AFL since he was "greatly disinclined to accept any salaried" position within the labor movement, but was finally persuaded to accept the office after being repeatedly nominated. The starting wage for such an office was one thousand dollars annually, but did not start for some 4 months after his election at the 1886 convention. Thus, for Gompers it was "a difficult economic struggle" during that period, when he had to devote his entire "time for those months without receiving salary or compensation," even while he had a family of eight to support. Nor did the economic troubles end after the salary began, for often he had to go without funds according to the needs of the union and its survival. His first office, which consisted of an eight by ten room, espoused the ascetic demands of the movement, filled with a bare minimum of rudimentary furniture. Money for the union and its operation was also scarce, so scarce that his son often borrowed ink from the local school to supplement their own meager stores. ${ }^{26}$ Sacrifice was part and parcel to the labor movement during this period, a historical fact that Higgins upheld as a religious ideal. Higgins believed that through their

\footnotetext{
${ }^{24}$ George G. Higgins, "Relations Between Employers and Workers Today" (address presented at the Christus Rex Congress, Warwick Hotel, Galway, Ireland, April 25, 1962), ACUA/GGH Papers, Box 326, Folder 1, 6.

${ }^{25}$ Higgins subscribed to the history provided by Gompers in Seventy Years of Life and Labor: An Autobiography.

${ }^{26}$ Samuel Gompers, Seventy Years of Life and Labor: An Autobiography, (New York: E.P. Dutton \& Co., 1925).
} 
sacrifice, Gompers and his contemporaries promoted a movement where "religious-minded men and women -- Protestants, Catholics and Jews - can be and actually are good trade unionists, not in spite of their religion, but precisely because... they are fervent in the practice of their faith and are guided, not completely of course but to a very large extent, by the social teaching of religion., 27

This sense of sacrifice was an essential component to the labor movement as a whole. After Higgins had become director of the Social Action Department, however, he began to worry that the labor movement was losing this key component of its identity. He began to ask whether those within "the American labor movement... understand why unions were established in the first place," and whether they understood "what their essential business or their essential purpose really" was. ${ }^{28}$ For Higgins, the answer was clear. Trade unionism sought to promote the "pursuit of justice and charity," and served the "advancement of human brotherhood in the field of economic life. ${ }^{29}$ In other words, the labor movement's "basic reason for existence... is to protect the rights and advance the welfare of the individual worker."30

The reason for questioning the direction of the labor movement stemmed from the problems Higgins observed within its rank-and-file. In this regard, Higgins relied upon two different works to justify his concerns over the direction of the labor movement, those being The Local Union: Its Place in the Industrial Plant, by Leonard Sayles and George Strauss, and The Worker Views His Union, by Joel Seidman and his associates from the Industrial Relations

\footnotetext{
${ }^{27}$ George G. Higgins, "Relations Between Employers and Workers Today" (address presented at the Christus Rex Congress, Warwick Hotel, Galway, Ireland, April 25, 1962), ACUA/GGH Papers, Box 326, Folder 1, 7 - 8.

${ }^{28}$ George G. Higgins, sermon preached at the Annual Diocesan Labor-Management Conference Mass, Gesu Church, Miami, Florida, August 30, 1962, ACUA/GGH Papers, Box 326 Folder 3, 6.

${ }^{29}$ George G. Higgins, sermon preached at the Annual Labor Day Mass, Shrine of the Sacred Heart, Washington, D.C., September 7, 1964, ACUA/GGH Papers, Box 326, Folder 11, 7.

${ }^{30}$ George G. Higgins, sermon preached at the Annual Labor Day Mass, Diocese of Toledo, Ohio, Sept. 1, 1958, ACUA/GGH Papers, Box 325, Folder 2, 7.
} 
Center of the University of Chicago. Sayles and Strauss argued that the majority "of the rankand-file... are 'sold' on their local union as a protective organization," and that they supported "its economic activities as useful and necessary and almost unanimously agree that 'without a union we would be lost." However, in the same breath those same workers also felt "no 'emotional identification' with the union and its goals," and many "of them regard their union as a sort of slot machine in which you insert your monthly dues with the hopes that something may come out. ${ }^{\not 1}$ Seidman and his contemporaries concurred in many ways, arguing that while the rank-and-file's union may have "become a powerful force in the larger society, the rank-and-file member... is likely to remain as nameless within his organization... [just] as he is in the society as a whole." The rank-and-file unionist "holds no office, attends no conventions, rarely if ever attends a meeting of his local union, and almost never speaks there." ${ }^{32}$ Following this presentation, Seidman broke down the typical rank-and-file union member into the following types:

(1) the ideological unionist; (2) the 'good' union man; (3) the loyal but critical member; (4) the crisis activist; (5) the dually-oriented member -- i.e., one who, while giving support to the union in all essential respects, views production and efficiency from the point of view of management and who has a reasonable hope and expectation of graduating to a supervisory or managerial position; (6) the card-carrier or indifferent member; and (7) the unwilling unionist. ${ }^{33}$

Higgins was disturbed by this breakdown, for Seidman's study of the rank-and-file determined that only two percent of its members could be considered as "ideological unionists," and ten

\footnotetext{
${ }^{31}$ Leonard R. Sayles and George Strauss, The Local Union: Its Place in the Industrial Plant (New York: Harper and Brothers Publishers, 1953), quoted by George G. Higgins, "Address at the Special Convocation in honor of The Late Sister Thomas Aquinas, O.P." (address presented at Rosary College, Chicago, Illinois, March 21, 1958), ACUA/GGH Papers, Box 325, Folder 1, 2.

${ }^{32}$ Joel Seidman, The Worker Views His Union (Chicago, IL: University of Chicago Press, 1958), quoted by George G. Higgins in prepared speech for Bishop Coleman Carroll, "Manuscript prepared for Bishop Carroll," April, 1958, ACUA/GGH Papers, Box 325, Folder 1, 6.

${ }_{33}$ Ibid., quoted by George G. Higgins, "Rank and File Apathy in Unions," The Yardstick, April 7, 1958, ACUA/GGH Papers, Box 346, Folder 6.
} 
percent as the "“good' union man." Consequently, Higgins believed - along with Seidman - that such members would only act in times of crisis. Such a form of participation greatly worried Higgins, for it meant the unions merely reacted from crisis to crisis, as opposed to working proactively to address the dilemmas it faced in the workplace.

The lack of participation by the rank-and-file was a source of great worry for Higgins, who believed that the movement's foundation rested upon ideals of sacrifice and charity. The loss of such ideals represented a movement which had lost its way. Nor was there an easy solution, for the movement was "dealing with a problem which... is too deeply rooted in human nature to be solved in a hurry or by the application of a panacea." ${ }^{34}$ Consequently, Higgins believed that the rank-and-file apathy present in the labor movement was a profound moral and religious crisis. From Higgins” vantage, it was “perhaps the most serious crisis in its entire history," and it was "basically a moral and spiritual crisis," which had "its roots within the labor movement itself." Simply put, the movement had strayed from its founding principles. In this instance, the major threat constituted the "dues-paying members and elected officers of its own affiliated organizations." The enemies of labor then were "within the fold," and labor had discovered that "no particular class of people in society... has a monopoly on virtue, not even the workers." ${ }^{, 35}$ In particular, Higgins believed "that too many of the newer members of the labor movement, the youngsters or Johnny-come-latelies... are like spoiled children who have had everything handed to them on a silver platter. They know very little, if anything, about the history and the early struggles of the labor movement, and they have inherited very little in the

\footnotetext{
${ }^{34}$ Ibid.

${ }^{35}$ George G. Higgins, address presented at the $16^{\text {th }}$ Constitutional Convention of the UAW, April 8, 1957 , ACUA/GGH Papers, Box 324, Folder 13, 3.
} 
spirit of sacrifice which characterized its founders. ${ }^{" 36}$ The labor movement had no place for such "nominal trade unionists -- like the nominal members of a church who come to services on Christmas and Easter and complacently let it go at that." ${ }^{37}$

This crisis had to be solved at the level of the average working union man, for as Higgins asserted, the "health of the entire labor movement is forged in the workshop of the local union," and the "health of the local union is forged in the soul of the individual rank-and-file member."38 In this sense, the local union served as the "the basic unit and the ultimate source of power" within the labor movement. ${ }^{39}$ The question then, was how to invoke a sense of social responsibility in individual members, the same sense of social responsibility that had been present in the time of the labor movement's founding. Higgins believed the answer lay in the religious roots of the labor movement, and that Catholics had a major role to play in the reviving of this spirit.

\section{The Introduction of Virgil Michel's Liturgical Movement as the Solution}

Higgins, due in large part to the influence of Virgil Michel, realized that individual reform was necessary to bring about social change on the institutional level. In the instance of labor unions, Higgins called upon its members to return to the religious origins of the movement, preferably "on their knees." In a similar manner, Virgil Michel called upon the lay community to return to their roots, and to turn away from the individualism which had pervaded society prior to

\footnotetext{
${ }^{36}$ George G. Higgins, sermon preached at the Annual Labor Day Mass, Diocese of Columbus, Saint Joseph's Cathedral, Columbus, OH, Sept. 3, 1956, ACUA/GGH Papers, Box 324, Folder 11, 2.

${ }^{37}$ Ibid., pp. 2 - 3.

${ }^{38}$ George G. Higgins, address presented at the $16^{\text {th }}$ Constitutional Convention of the UAW, April 8, 1957 , ACUA/GGH Papers, Box 324, Folder 13, 4.

${ }^{39}$ George G. Higgins, address presented to the Twelfth Annual City-Wide Conference, Local 688, International Brotherhood of Teamsters, Jan. 30, 1955, ACUA/GGH Papers, Box 324, Folder 3, 2.
} 
the Great Depression. And as both men understood it, Catholics had an essential role to play in changing the temporal order of the world. For Higgins, it became clear that Catholics would best serve to revive the rank-and-file of the unions, and by doing so would usher in the social change that both Higgins and Michel desired.

According to the data Higgins had at hand, sixty-six percent of American Catholics were part of the "lower" class, which contributed to the fact that "Catholics have a higher percentage of people in the trade-unions than any other religious body." 40 This made sense to Higgins, since Catholic social teaching endorsed "the right of labor to organize and... Catholic workers, to a greater degree than many of their fellow-workers, have been encouraged by their Church to exercise this right." Consequently, Higgins also believed that Catholics had a much stronger moral obligation to meet the demands of belonging to a union, that Catholic workers had "a proportionately greater responsibility for what goes on -- and what doesn't go on -- in the labor movement." Unfortunately, like so many of their fellow non-Catholic compatriots, Catholic unionists were just as guilty in failing to live up to the demands of labor. They too exhibited the "failure of too many trade unionists... to look beyond the present moment and to ask themselves, preferably on their knees, what the purpose of unions really is or what the labor movement is all about." 41

Higgins believed that the reason for such a failure by Catholics to understand the purpose of their union lay in their lack of a spirituality or theology to guide them in the temporal world. When it came to the laity and social action, Higgins argued that the Church had been "putting the

\footnotetext{
${ }^{40}$ Vance Packard, The Status Seekers: An Exploration of Class Behavior in America and the Hidden Barriers That Affect You, Your Community, Your Future (New York: David McKay Company, 1959), 203; Higgins quotes Packard in his "Don't Forget the First Beatitude" Yardstick column of Aug. 31, 1959 (ACUA/GGH Papers, Box 346, Folder 11).

${ }^{41}$ George G. Higgins, “Don't Forget the First Beatitude," The Yardstick, Aug. 31, 1959, ACUA/GGH Papers, Box 346, Folder 11.
} 
cart before the horse." In other words, the Church had "been appealing to the laity to engage in Catholic social action without first telling them, theologically, why they ought to do so and without supplying them with the proper spiritual motivation.” Much like his charge that organization was an obligation of all workers and employers, so too did Higgins argue that social action was an obligation for all Catholics. This was a charge derived from Michel's theology of the Mystical Body, as Higgins argued that lay responsibility for social justice stemmed from the sacrament of confirmation. As a sacrament, both Michel and Higgins believed that confirmation changed the character of a person and oriented them towards Christ's work in the world around them. According to Michel, confirmation was "the sacrament of official lay apostleship." Lay apostleship imposed an "apostolate of Catholic Action" upon the individual member of the Church, and it was through the sacrament that all members of the Church became "soldiers of Christ." 42 In the same manner, Higgins believed that any "layman who has been confirmed has an obligation to engage in Catholic social action within the limits of his talents and ability and according to the opportunities which are afforded to him in his particular state of life. That is to say, lay participation in the social apostolate of the Church is not just a hobby or an avocation for those who happen to be temperamentally so inclined."43

The theological impetus that would serve to foster this sense of obligation, as well as encourage a desire to promote justice and charity in the world around them, was the liturgical movement. Higgins readily acknowledged that the social action movement had failed "to build its program around the Church's liturgy which... is the indispensable basis of an adequate

\footnotetext{
${ }^{42}$ Virgil Michel, "Liturgy and the Catholic Life," unpublished manuscript, 71, quoted in Paul B. Marx, O.S.B., Virgil Michel and the Liturgical Movement (Collegeville: The Liturgical Press, 1957), 193.

${ }^{43}$ George G. Higgins, "The Laity and Social Action," The Yardstick, Dec. 24, 1956, ACUA/GGH Papers, Box 345, Folder 16.
} 
program of social reconstruction." ${ }^{44}$ Furthermore, if Catholic social action was to be effective, and if the labor movement was to return to its religious roots, a liturgical foundation based on the sacraments and the Mass was essential in achieving this goal. As Higgins would argue, it was only with Christ that "the labor movement can go forward to create a culture which will be truly representative of man's essential dignity and worth. Apart from Christ it will inevitably go the way of all flesh and will betray the cause of social justice to which it is dedicated." ${ }^{, 45}$ As for Catholic social action, it was "a slogan worse than meaningless, if it does not include personal union with Christ, nourished and fostered by frequent reception of the sacraments, and by unremitting prayer and penance." 46

In order fully to appreciate the importance of the liturgy, the laity of the Church had to change their own understanding of their place within it, and their relationship with both the clergy and the hierarchy. Utilizing Michel's theology, as well as that of Pius XII's Mediator Dei, Higgins called for the laity to understand their own identity as that of the Mystical Body. This growing awareness or consciousness of membership in Christ's Mystical Body," would culminate in the "restoration of peace and political order to the world." ${ }^{, 47}$ Fortunately, this was an identity in which the laity could readily partake, for "Christ was a worker; moreover, that in His divine wisdom He deliberately chose to be a worker." ${ }^{48}$ By sharing in this station, the lay members also assumed a similar mission that Christ had assumed during his time on Earth, the

\footnotetext{
${ }^{44}$ George G. Higgins, "Integration of the Liturgy and Social Action," The Yardstick, April 28, 1958, ACUA/GGH Papers, Box 346, Folder 6.

${ }^{45}$ George G. Higgins, address presented at the Communion Breakfast, Saint Patrick's Cathedral Parish, Norwich, Connecticut, March 10, 1957, ACUA/GGH Papers, Box 324, Folder 12, 3.

${ }^{46}$ George G. Higgins, "Christ in All Things," St. Thomas Seminary Newsletter, Denver, Colorado, April, 1953, ACUA/GGH Papers, Box 323, Folder 12, 1.

${ }^{47}$ George G. Higgins, "The Mass and the Political Order" (address presented at the $16^{\text {th }}$ National Liturgical Week in Worcester, MA, Aug. 24, 1955), ACUA/GGH Papers, Box 324, Folder 4, 128.

${ }^{48}$ George G. Higgins, address presented at the Communion Breakfast, Saint Patrick's Cathedral Parish, Norwich, Connecticut, March 10, 1957, ACUA/GGH Papers, Box 324, Folder 12, 1.
} 
work to bring peace and justice to their fellow man. Consequently, this identity as being part of the Mystical Body of Christ would aid the laity in the social charge given them by the sacrament of confirmation. These were the same responsibilities charged by Pius the XII in his address to the Congress of the International Union of Catholic Women's Leagues on September 11, 1947, when he told them to be

present everywhere for the faith, for Christ, in every way and to the utmost possible limit, wherever vital interests are at stake, wherever laws bearing on the worship of God, marriage, family, the school, the social order are proposed and discussed. Be there, on guard and in action, whenever through education the soul of a people is being forged. ${ }^{49}$

Higgins argued that such a charge was not limited to the women of the Church, but reminded the laity that such was the responsibility of all its members, that all were called to

stand up and be counted, as Christians and as Catholics, whenever the rights of the poor and the rights of the workingman are being infringed upon. More than that, we shall be called upon to assume the initiative in working for the fullest possible advancement of these rights. ${ }^{50}$

As it was with Virgil Michel, for Higgins it was the Mass which stood out as the single most important aspect in reinforcing this identity of the Church as the Mystical Body of Christ. Higgins argued that the Mass took precedence since it was "the Mass which is the primary source of ascetism and penance without which there can be no conversion from human selfishness or sin and no redemption either of individuals or the temporal order." ${ }^{51}$ The Mass was particularly important in converting the social order since it promoted a "sense of a fellowship

\footnotetext{
${ }^{49}$ Pope Pius XII, “Allocution to the Congress of the International Union of Catholic Women's Leagues" (address presented in Rome, Italy, September 11, 1947), quoted in George G. Higgins, address presented at the Catholic Alumnae Dinner, Oct. 20, 1956, ACUA/GGH Papers, Box 324, Folder 5, 2.

${ }^{50}$ Ibid., $5-6$.

${ }^{51}$ George G. Higgins, "The Mass and the Political Order" (address presented at the $16^{\text {th }}$ National Liturgical Week in Worcester, MA, Aug. 24, 1955), ACUA/GGH Papers, Box 324, Folder 4, 135.
} 
of all in relation to all," which served both the supernatural and the political order. " ${ }^{52}$ "The spiritual force for the development of this fellowship comes from

Christ, from the Mystical Body, the corporate Christ. The great embodiment of this force in the world today is the liturgy and especially the Mass, which is Christ and people acting together. The Mass shows forth the supreme worth of the individual. The individual is present at Mass as a divinized creature, and the Mass in turn enhances that divinization, that supreme worth. But the individual is present at Mass as a member of the group - acting, giving, receiving, worshipping together with his fellow Catholics. This corporateness, this sense of fellowship of all in relation to all, should be and must be carried into the political order where a man's individual contribution is more important than he thinks it is. ${ }^{53}$

Such a contribution was not only essential to the life of the Church, but also to that of a democracy, especially the United States. "Under a non-democratic political system the average citizen is not too deeply implicated, if at all, in the failures, much less the crimes, of the regime. In varying degrees, he is merely a passive creature of the powers that be, whether these powers be tyrannical or benevolent." This was not the case in a democratic government, where "each citizen is to some extent responsible for the contemporary failures" of their government."54 Unlike other forms of government, democracy was "based on a sense of the priceless dignity and worth of the individual man coupled with a sense of the dependence of all men on one another a sense of working together to make it succeed. It is a government of, by, and for the people, not as isolated or atomized individuals, but as brothers living and working together, with a minimum of external compulsion, for the common temporal good of all." ${ }^{, 55}$ By encouraging the communal sense that the Mystical Body espoused, the Mass promoted a citizenry that was essential for

\footnotetext{
${ }^{52}$ Henri De Lubac, Catholicism, (New York: Longmans, Green and Company, 1950), 202, quoted in George G. Higgins, "The Mass and the Political Order" (address presented at the $16^{\text {th }}$ National Liturgical Week in Worcester, MA, Aug. 24, 1955), ACUA/GGH Papers, Box 324, Folder 4, 136.

${ }^{53}$ George G. Higgins, "The Mass and the Political Order" (address presented at the $16^{\text {th }}$ National Liturgical Week in Worcester, MA, Aug. 24, 1955), ACUA/GGH Papers, Box 324, Folder 4, 136.

${ }^{54}$ Ibid., 134.

${ }^{55}$ Ibid., 135.
} 
democracy's well-being. Yet, as Higgins would point out, the United States had not yet become a democracy entirely focused on social justice as an expression of the well-being of its community. Instead, what Higgins saw was a democracy that focused "too single-mindedly upon the individual as the sole unity of society and upon the state as the sole source of legitimate power. ${ }^{, 56}$

The solution to such a democratic form lay in the Industry Council Plan that Higgins had promoted throughout the years. For Higgins, this meant the inclusion of voluntary associations collaborating with the government for the common good, which had not yet occurred. Higgins lauded the fact that the state had not prohibited the formation of voluntary associations, but lamented that American democracy had not yet included them as a necessary force in the management of economic life and social justice. From his perspective, neither the state nor its populace had "formulated a theory of democracy that includes these organizations, that makes them indispensable to free, representative government. ${ }^{, 57}$ If they had done so, a system similar to the one Higgins had proposed in the Industry Council Plan - meaning a federated council of voluntary organizations according to profession, industry, and labor - would have existed by that time.

The liturgy was a necessary fulcrum which would serve to influence the formation of such a system. By realizing the Christ that existed within them, Higgins believed that man would "no longer content himself with humanizing individual lives," but would begin to "Christianize 'social institutions'." By doing so, members of the Mystical Body would create a system which would "make it easier for the average man to save his soul without the exercise of heroic

\footnotetext{
${ }^{56}$ Ibid., 137.

${ }^{57}$ Ibid.
} 
virtue. ${ }^{, 58}$ This was not to say that the liturgy provided all the answers, for Higgins did not see an avenue whereby the liturgy supplied a complete theory. Rather, he believed the liturgy fostered the development of such a system, for it could "spiritually prepare the Catholics of the United States to take the lead in developing such a theory as one more step forward in mankind's quest for a more perfect community in the political and economic order." In his mind, the "liturgy, especially the Mass-liturgy," was "the source of those virtues of justice and charity necessary in the quest for community." 59

Higgins, as a priest, realized that he could not bring about such change on his own. Neither could any other member of the clergy, the hierarchy included. Rather, the lay members of the Church, acting as both citizens and as members of the Mystical Body, were the only ones who could effectively bring about such change. If the United States were to adopt such a system - whereby voluntary associations participated in the economic management of the nation with the government - then this social reform, if it was "to be effective and lasting, must come from below: they cannot be imposed from above." Consequently, it was "the vocation of the laity to take this initiative, with the aid and blessing of God." ${ }^{, 60}$

Much like Michel, Higgins argued that as members of the Mystical Body of Christ, this was the primary role of the laity in the secular world. They alone could influence such change, for it was their place to do so. Redemption of the social order was "the function of the layman in

\footnotetext{
${ }^{58}$ George G. Higgins, "Christ in All Things," St. Thomas Seminary Newsletter, Denver Colorado, April, 1953, ACUA/GGH Papers, Box 323, Folder 12, 2.

${ }^{59}$ George G. Higgins, "Opportunity for U.S. Catholics," The Yardstick, May 15, 1961, ACUA/GGH Papers, Box 347, Folder 6.

${ }^{60}$ George G. Higgins, sermon preached at the Mass in Honor of St. Joseph, the Worker, at the Mission San Jose, San Antonio, Texas, May 1, 1959, ACUA/GGH Papers, Box 325, Folder 3, 5.
} 
all walks of life." ${ }^{\prime 1}$ This was not to say that Higgins believed priests did not have a role in the reconstruction of the social order, but rather that he argued the Church needed "more lay apostles because there are certain things that only the layman has competence to do - regardless of the number of priests at any given time or place." 62 According to Higgins, this would have remained the case "even if we had 400,000 priests in the United States instead of 45,000 or 50,000 ," because "these 400,000 priests... are not 'competent' to do so." ${ }^{63}$ The reason for such a lack of competence was that the priest could never be "directly engaged in the activities of the marketplace," whereas the lay members of the Church, due to their station in life as workers, were. $^{64}$

Rather, it was the place of the priest to guide and instruct the faithful in their secular mission to "restore all things in Christ." 65 This was their competence in "the field of social action", a duty that had been charged by Pius XI. Citing the late pontiff, Higgins argued that their obligation was "to search diligently for... lay apostles both of workers and of employers, to select them with prudence, and to train and instruct them properly." ${ }^{66}$ Both clergy and laity had the same mission, but it was only the laity who could accomplish the work that would bring about such social change. In this sense, the clergy served in the same capacity as would the captain of a ship, but with the realization that " the captain of a ship as well as the passengers are

\footnotetext{
${ }^{61}$ George G. Higgins, address presented at the Communion Breakfast at the Catholic Interracial Council, Baltimore, MD, January 18, 1959, ACUA/GGH Papers, Box 325, Folder 3, 3.

${ }^{62}$ George G. Higgins, sermon preached at the Mass in Honor of St. Joseph, the Worker, at the Mission San Jose, San Antonio, Texas, May 1, 1959, ACUA/GGH Papers, Box 325, Folder 3, 4.

${ }^{63}$ Ibid., $4-5$.

${ }^{64}$ Ibid., 5.

${ }^{65}$ George G. Higgins, sermon preached at the First Mass of Father Thomas E. Gallenbach, Decatur, Illinois, May 31, 1958, ACUA/GGH Papers, Box 325, Folder 2, 10.

${ }^{66}$ George G. Higgins, sermon preached at the Mass in Honor of St. Joseph, the Worker, at the Mission San Jose, San Antonio, Texas, May 1, 1959, ACUA/GGH Papers, Box 325, Folder 3, 5.
} 
in the same condition as to safety or danger." ${ }^{, 67}$ If the clergy were to attempt the reconstruction of the social order apart from that of the laity, they "would tear [themselves] apart physically as well as spiritually." ${ }^{\prime 68}$ The work was simply too much for any priest, given the duties assigned to him by vocation. A priest's duties were enough as they were, for the priest had to "be a man of active charity, a man of culture and learning, a keen observer of current affairs, an efficient administrator, and a hundred other things. In short, he must be 'equipped for every good work.' But, more important than anything else, he is expected to be a man of prayer." The priest's duties were primarily that of the spiritual realm, as they practiced lives of prayer and "priestly learning." Thus, his greatest temptation was to ignore this calling, "to neglect his prayers in favor of the so-called active ministry." ${ }^{69}$ It was the laity, as members of the Mystical Body, who had "an indispensable role to play in bridging the gap between the Church and temporal society.,"70

\section{Higgins's Path to Social Order: A Middle Way}

Higgins, through Michel and his liturgical theology, advocated an individual reform that would lead to institutional change. This individual reform, in and of itself, was not enough however, for the identity that brought about such individual reform was tied to a concept of community. Michel helped Higgins realize that individual and social reform had to complement one another. Consequently, Higgins believed that an

exclusive emphasis on the reform of institutions, with little or no attention being given to the reform of personal morality, is secularism, pure and simple -

\footnotetext{
${ }^{67}$ George G. Higgins, sermon preached at the First Mass of Father Thomas E. Gallenbach, Decatur, Illinois, May 31, 1958, ACUA/GGH Papers, Box 325, Folder 2, 9.

${ }^{68}$ Ibid., 8.

${ }^{69}$ Ibid., 9.

${ }^{70}$ George G. Higgins, "The Church and the Temporal Order," The Yardstick, Oct. 5, 1959, ACUA/GGH Papers, Box 346, Folder 12.
} 
humanitarian in purpose and intention, no doubt, but tragic in its consequences. On the other hand, an exclusive emphasis on personal reform, with little or no attention being given to the reform of social institutions, is an even more subtle delusion and equally damaging in its practical results. ${ }^{71}$

Thus, there were two temptations that might threaten the lay apostolate and its call of social justice then. Each was "as dangerous as the other, and just as harmful to the cause of Christ and His Mystical Body." The first was the temptation to "concentrate exclusively on political, social, and economic reform and to forget that heaven... is our final destination." Such a temptation was "to pull ourselves up by our own bootstraps -- to become so completely immersed in the apostolate of 'good works' is to forget that 'unless the Lord keep the city, he watcheth in vain that keepeth it." ${ }^{, 72}$ Social reform had to be accomplished in conjunction with the Mystical Body of Christ, not apart from it. Secondly, the other temptation was "to withdraw into a comfortable spiritual vacuum and consciously disassociate ourselves, in the name of virtue, from the never-ending struggle for social justice." ${ }^{, 73}$ Such a decision failed to recognize the human element of the Mystical Body, the fact that Christ came to the world as a man to help his fellow men and women.

The answer was that the individual had to recognize their "social responsibility... to be physically and spiritually present as a witness to Christ in his own environment and among his confreres, whatever his occupation." And while Catholic associations were beneficial in this regard, Higgins did not envision them as integral to engaging society at large. His vision of the social apostolate did not mean simply "passing resolutions at the meetings of fraternal

\footnotetext{
${ }^{71}$ George G. Higgins, address presented at the Communion Breakfast, Saint Patrick's Cathedral Parish, Norwich, Connecticut, March 10, 1957, ACUA/GGH Papers, Box 324, Folder 12, 8.

${ }^{72}$ George G. Higgins, address presented at the Sodality Meeting at Blessed Sacrament Parish, Washington, D.C., Nov. 3, 1954, ACUA/GGH Papers, Box 324, Folder 2, 5; Higgins is quoting Psalm 127, verse 1.

${ }^{73}$ Ibid.
} 
organizations." Instead, he argued that the lay person had to engage their "own appropriate economic organization" as a member of the Mystical Body. ${ }^{74}$ By doing so, the laity would Christianize the social order by his or her presence and action within it. Consequently, lay Catholics had to be engaged as representatives of Christ in the world around them, particularly in their economic associations. In the case of the worker, this meant his or her union.

In the end, Higgins created a system whereby the individual lay Catholic was not only responsible for the social order and its reconstruction, but whose role as a lay person was essential for its reform. Furthermore, it was a role that defined the lay person in relation to the clergy and the hierarchy, and empowered them as representatives of the Church in the secular world. He carried these beliefs with him when he became a peritus, or theological expert, for the Second Vatican Council in October of 1962. The following chapter details his time at the Council, and his efforts to develop in greater detail his understanding of the lay social apostolate and its role within Church during this time, especially in light of the encyclicals of Pope John XXIII, Mater et Magistra and Pacem in Terris.

\footnotetext{
${ }^{74}$ George G. Higgins, address presented at the Communion Breakfast at the Catholic Interracial Council, Baltimore, MD, January 18, 1959, ACUA/GGH Papers, Box 325, Folder 3, 5.
} 


\title{
Chapter 6
}

\section{The Unified Apostolate for the Universal Church: The Impact of the Encyclicals of Pope John XXIII and their Culmination at the Second Vatican Council}

\begin{abstract}
Catholic lay organizations in the field of social reform should not be thought of as a substitute for trade unions, employers' organizations, professional associations, political parties, or what have you. On the contrary, the effectiveness of a Catholic lay organization in the social apostolate should be measured, normally, not so much by the scope of its own action programs in the field of social reform, but rather by the involvement of its members in the above mentioned secular organizations and by their success in helping these secular organizations to develop more effective programs of their own.
\end{abstract}

- Rev. George G. Higgins, The Yardstick, March 30, 1964 $\phi$

The 1960s were a seminal period for George Higgins and his continued development of a social apostolate for the laity of the Catholic Church. On January $25^{\text {th }}, 1959$ Pope John XXIII called for a general Council for the universal Church, which would later be named the Second Vatican Council. A little over a year following Pope John's announcement, Higgins was invited to serve as a member of one of its preparatory commissions, the Commission on the Apostolate of the Laity. ${ }^{1}$ It was one commission of many, formed in anticipation of the theological demands that the Council would require, as over two-thousand bishops met to reform the Church. While serving as a member of this preparatory Commission, Higgins helped address the place of neutral associations in relation to Pius XI's definition of Catholic Action, as well as their role in the lay

\footnotetext{
${ }^{1}$ Unfortunately, documentation surrounding Higgins' time at the Second Vatican Council, including his work for the preparatory commission is limited. Gerald M. Costello, while writing Without Fear or Favor: George Higgins on the Record, misplaced several boxes of documents pertaining to Higgins' work at the council. Consequently, the Catholic University of America archives do not have full documentation of this period. What documents do remain are scattered throughout Higgins' Yardstick articles, as well as the files containing his speeches, addresses, and lectures. As a consequence, while documentation proves that Higgins served as a member of the preparatory Commission on the Apostolate of the Laity, it does not provide an exact date of his invitation and acceptance.
} 
apostolate. It was also during his service on the preparatory commission for the lay apostolate that Pope John published the encyclical Mater et Magistra, the next social encyclical in the line of Rerum Novarm and Quadragesimo Anno. ${ }^{2}$ The encyclical served to validate Higgins's social efforts from years past, as it reaffirmed the principles of the social encyclicals that came before it. More importantly for Higgins, the encyclical validated his efforts to provide a liturgical and theological basis for the social apostolate by calling for the harmonization of the laity's spiritual and secular lives. This validation, along with his work on the preparatory Commission on the Apostolate of the Laity, served Higgins well when he became a peritus, or theological expert, of the Council shortly before it convened on Oct. 11, 1962. Once again, he worked on defining the role of the laity within the Church, serving as a member of the Commission of the Lay Apostolate at the Council, whose contribution led to the Decree on the Apostolate of the Laity, Apostolicam Actuositatem. This was not the only commission to which he belonged, however. By February of 1963 Higgins had also joined the mixed commission composed of members from the Doctrinal Commission and the Commission on the Apostolate of the Laity. This mixed commission was entrusted with Schema 17, known at the time as "The Efficacious Presence of the Church in the World," and it was from this schema that the mixed commission developed what would become Gaudium et Spes, the Pastoral Constitution on the Church in the Modern World. $^{3}$

Six months after the opening of the Council, Pope John published Pacem in Terris on April 11, 1963. The encyclical recognized and affirmed the inalienable rights of humanity, and called upon the nations of the world to collaborate with one another for the common good of all.

\footnotetext{
${ }^{2}$ Even though Mater et Magistra was published on July 14, 1961, it was dated as May 15, 1961 in honor of the $70^{\text {th }}$ anniversary of Rerum Novarum.

${ }^{3}$ Vincent Yzermans, American Participation in the Second Vatican Council (New York: Sheed and Ward, 1967), 186 - 191; It should be noted that the schema was originally known as Schema 17, but was later called Schema 13.
} 
Besides this exhortation, Pope John also called upon Catholics to join non-Catholics in this effort, both on an individual and corporate basis. This exhortation by the Pope, coupled with the recognition of humanity's right to honor God according to the dictates of their conscience, once again reaffirmed Higgins's belief that the laity's place in the Church was to change the social order through the mixed and neutral associations to which they belonged.

Higgins applied the precepts of both Mater et Magistra and Pacem in Terris in his development of a lay social apostolate for the United States. In particular, he related these principles and argued that they were an inherent part of the development of the conciliar decree Gaudium et Spes. However, he also argued that the Council's decree on the Dogmatic Constitution of the Church, Lumen Gentium, had to be considered in relation to the lay apostolate, and its role within the modern world. By doing so, Gaudium et Spes served as the summation of his work of developing the lay apostolate. His belief that lay Catholics' secular and spiritual lives could exist in harmony with one another had been established by conciliar decree.

\section{Higgins and the Preparatory Commission}

Higgins was well qualified for the preparatory commission concerning the lay apostolate. By the time he joined, he had already promoted Virgil Michel's theology of the Mystical Body in his effort to provide a theological basis for the social apostolate. By doing so, Higgins had already formed the theological underpinnings necessary to address the place of the laity within the life of the Church, as well as the role of "Catholic Action," which was the preparatory commission's purview. The definition of Catholic Action had not changed since Pius XI had defined it on June 29, 1931, when he published the encyclical Non Abbiamo Bisogno. It defined Catholic Action as 
the laity's effort to change the social order according to the principles of the faith, but done so under the direct supervision and guidance of the hierarchy. Higgins's injection of Virgil Michel's theology into the lay apostolate challenged this model by calling upon the laity to take the initiative, regardless of hierarchical supervision. In particular, Michel had argued that only lay Catholics had the competence to bring about such change in the temporal order, and by doing so he empowered lay Catholics in this role. Consequently, the guidance of the hierarchy was secondary to this concern. Higgins's adaptation of Michel's theology similarly encouraged lay Catholics as he sought to promote their involvement in secular unions. Thus, Higgins entered the preparatory commission with predetermined views concerning the lay apostolate, and how such an apostolate should function within a pluralistic society. His efforts to realize these goals would remain his focus throughout his work at the Second Vatican Council.

Of particular importance to Higgins, the preparatory commission sought to define the scope of the apostolate, how it could be adopted to meet contemporary needs, the definition of Catholic Action, and how both it and the lay apostolate were meant to interact with the hierarchy. ${ }^{4}$ As a consequence of these topics, the commission also addressed Catholic participation in social organizations that included non-Catholics. The preparatory Commission on the Apostolate of the Laity concluded its work with its text, "Schema Constitutionis de apostolatu laicorum," which proposed that all members of the Church have a right and a duty to be actively involved in its life. It defined the laity as "Christian believers to whom the common rights and duties of persons in the Church belong and who, while not belonging to the clerical state or to the state of perfection, are called to attain their Christian perfection amid the affairs of the world."5

\footnotetext{
${ }^{4}$ Guiseppe Alberigo \& Joseph A. Komonchak, History of Vatican II, Vol. I: Announcing and Preparing Vatican Council II Toward a new Era in Catholicism (Maryknoll \& Leuven: Orbis and Peeters Publishers, 1995), 197. ${ }^{5}$ Commission on the Apostolate of the Laity, "Schema Constitutionis de apostolatu laicorum," April, 1962, quoted in Guiseppe Alberigo \& Joseph A. Komonchak, History of Vatican II, Vol. I: Announcing and Preparing Vatican
} 
Furthermore, the text defined Catholic Action as those forms of lay activity directly under the supervision and direction of the hierarchy. Besides this, the document also defined the relation of charitable activities that fell under state guidance, important in that it asserted that the laity should take part in "mixed or neutral associations," which allowed lay members of the Church to work with non-Catholics in social charity organizations without fear of compromising their faith.

The preparatory commission's actions were a solid foundation for Higgins and his goal of adapting the social apostolate for the Church in the United States. For while it's Schema still defined Catholic Action as those forms of lay activity under the direct supervision of the hierarchy, it also opened the possibility that there "other forms" of the social apostolate available to the laity. ${ }^{6}$ In particular, the preparatory commission's schema presented Catholic lay participation in "mixed or neutral" associations as one of these acceptable forms. Consequently, Higgins's felt justified in his assertion that lay Catholic participation in unions was an acceptable means to pursue Catholic social change.

Besides this justification, the commission also validated much of the work that Higgins and the SAD of the NCWC had completed with the aid of both Protestant and Jewish bodies, which had always been the elephant in the room for the department. Only ten years prior, Higgins's predecessor, Raymond McGowan, had to defend inter-faith statements and cooperation. At that time, another member of the Social Action Department had warned McGowan "in like circumstances Catholics should make use of their own statements so as not to

Council II Toward a new Era in Catholicism (Maryknoll \& Leuven: Orbis and Peeters Publishers, 1995), 198; The Catholic "state of perfection" may be best understood in light of the definition offered by Thomas Aquinas in his Summa Theologica. It defines this state as the utmost pursuit of charity, and is most often identified with the members of the Church who have taken vows of poverty, chastity, and obedience in the pursuit of spiritual perfection, which he considers to be the bishops and those in religious orders.

${ }^{6}$ Guiseppe Alberigo \& Joseph A. Komonchak, History of Vatican II, Vol. I: Announcing and Preparing Vatican Council II Toward a new Era in Catholicism (Maryknoll \& Leuven: Orbis and Peeters Publishers, 1995), 198; Komonchak notes that the preparatory commission's schema did not define exactly what these "other forms" were, however, arguing that the present time was not conducive for determining their terminology. 
give the impression that they and non-Catholics stand on the same level., ${ }^{, 7}$ In response,

McGowan had to defend himself and the Department's actions by outlining the various times and circumstances such joint statements had been issued, and their effect, which he considered largely beneficial. Higgins's work as a member of the Commission on the Apostolate of Laity served to clarify the position of the Church on inter-faith issues, and help prevent any such future misunderstandings.

Higgins's own work in the field of labor relations paralleled McGowan's defense, as much of the work Higgins performed was in collaboration with those of other faiths, such as his work with Arthur Goldberg, who was Jewish, during the AFL-CIO merger of $1955{ }^{8}$ Higgins's work with Goldberg, among others, contributed to his belief that the "beginnings of the labor movement in this country are largely the fruit of a Catholic-Jewish coalition ... [and that] Catholics and Jews joined (one might say were almost forced) together into coalitions to achieve the social and political goals that neither community could have won on its own." Consequently, Higgins would have interpreted his work on the preparatory commission through the same lens as that of his work in labor relations, work which required him to collaborate with non-Catholics, particularly in neutral associations. Furthermore, it matched his understanding of the role of the labor movement as a religiously principled movement, a movement where "religious-minded men and women - Protestants, Catholics and Jews - can be and actually are good trade unionists, not in spite of their religion, but precisely because... [of their fervor] in the practice of their faith

\footnotetext{
${ }^{7}$ Raymond McGowan to Msgr. Carroll, December 22, 1950, ACUA/GGH Papers, Box 69, Folder 9.

${ }^{8}$ Arthur Goldberg was the former Secretary of Labor for John F. Kennedy, and later served as a Supreme Court Justice from 1962 to 1965. In regard to labor, Goldberg participated in the merger of the AFL and CIO in 1955, serving as an advisor to both unions (Pritzker Legal Research Center, "The Supreme Court Papers of Arthur J. Goldberg: Arthur J. Goldberg: Biographical Note,” http://goldberg.law.northwestern.edu/mainpages/bio.htm (accessed 10.25.2013)).

${ }^{9}$ George G. Higgins, "For Christians and Jews: A Golden Anniversary," The Yardstick, July 31, 1978, ACUA/GGH Papers, Box 294, Folder 2.
} 
and are guided, not completely of course but to a very large extent, by the social teaching of religion."

This defense of inter-faith cooperation was an integral part of Higgins's vision of the social apostolate in America; his vision of the lay apostolate relied upon their involvement in mixed or neutral associations, particularly unions. Mater et Magistra supported Higgins in his defense, and provided him a sound basis upon which to support his call for a unified apostolate. Such an apostolate relied upon the laity to influence and reform the temporal order, doing so through the secular institutions to which they belonged, and which Higgins had supported throughout the years in his work for the Social Action Department. This apostolic work required Catholics to engage the modern world, with those whose faith differed from their own.

Moreover, it rejected the separatist subculture that had dominated Catholic life during its immigrant years, and to which many Catholics still understood as their role in lay Catholic life. ${ }^{11}$

\section{Mater et Magistra}

Pope John XXIII's first social encyclical reaffirmed the Church's role as Teacher, but also emphasized its place as the Mother of the faithful. The Church "was entrusted by her Holy Founder the twofold task of giving life to her children and of teaching them and guiding them both as individuals and as nations - with maternal care." ${ }^{\prime 12}$ Published on July 14, 1961, Mater et Magistra reassessed the social encyclicals of his predecessors, Rerum Novarum and

\footnotetext{
${ }^{10}$ George G. Higgins, "Relations Between Employers and Workers Today" (address presented to Christus Rex Congress, Warwick Hotel, Galway, Ireland, April 25, 1962), ACUA/GGH Papers, Box 326, Folder 1, 7 - 8.

${ }^{11}$ Robert Orsi's The Madonna of $115^{\text {th }}$ Street: Faith and Community in Italian Harlem, 1880 - 1950, and Paula M. Kane's Separatism and Subculture: Boston Catholicism, 1900 - 1920 serve as excellent examples of the separatist subculture immigrant Catholics had created in the United States during the 1900s.

${ }^{12}$ Pope John XXIII, "Mater et Magistra: Encyclical of Pope John XXIII On Christianity and Social Progress," The Holy See, http://www.vatican.va/holy father/john xxiii/encyclicals/documents/hf_jxxiii_enc_15051961_mater_en.html (accessed 10.26.2013).
} 
Quadragesimo Anno, in light of the modern day that Pope John XXIII faced..$^{13}$ In particular, Pope John XXIII's encyclical gave special consideration to Leo's treatment of the role of the Church in society, the dignity and natural rights of the worker, and the duty and obligation that government owed in this regard. It reaffirmed the principle of subsidiarity, arguing that "the 'principle of subsidiary function' must be observed" in matters of property, and that the "State and other agencies of public law must not extend their ownership beyond what is clearly required by considerations of the common good." Even further, it warned that should the State seize too much property, that "private ownership could be reduced beyond measure, or, even worse, completely destroyed." ${ }^{14}$ In this sense, Mater et Magistra affirmed Pope Leo's understanding of property and its relation to humanity. According to Rerum Novarum, Property had been granted by God to humanity "for the purpose of... perfecting his own nature, and, at the same time... for the benefit of others." ${ }^{15}$ Consequently, the ownership of private property was part of the natural law of humanity. Pope John affirmed this as well, arguing that the "right of private ownership of goods, including productive goods, has permanent validity," and was a part "of the natural order."16

Yet Mater et Magistra was not simply a reaffirmation of Rerum Novarum and Quadragesimo Anno. It broke new ground by applying these principles to international relations, calling upon all nations to address the imbalance of natural resources and population. In

\footnotetext{
${ }^{13}$ Even though Mater et Magistra was published on July 14, 1961, it was published in honor of the seventieth anniversary of the first great social encyclical of the Church, Pope Leo XIII's Rerum Novarum, published on May $15,1891$.

${ }^{14}$ Ibid.

${ }^{15}$ Pope Leo XIII, “Rerum Novarum: Encyclical of Pope Leo XIII On Capital and Labor,” The Holy See, http://www.vatican.va/holy_father/leo_xiii/encyclicals/documents/hf_l-xiii_enc_15051891_rerum-novarum_en.html , quoted in Pope John XXIII, "Mater et Magistra: Encyclical of Pope John XXIII On Christianity and Social Progress," The Holy See, http://www.vatican.va/holy_father/john_xxiii/encyclicals/documents/hf_jxxiii_enc_15051961_mater_en.html (accessed 10.26.2013).

${ }^{16}$ Pope John XXIII, "Mater et Magistra: Encyclical of Pope John XXIII On Christianity and Social Progress," The Holy See, http://www.vatican.va/holy father/john_xxiii/encyclicals/documents/hf_jxxiii_enc_15051961_mater_en.html (accessed 10.26.2013).
} 
particular, the encyclical called upon the economically advanced nations of the world, whose natural resources had helped create such wealth, to aid poorer nations through scientific and financial assistance. This was an obligation of all prosperous nations, since the "solidarity which binds all men together as members of a common family" also made it "impossible for wealthy nations to look with indifference upon the hunger, misery and poverty of other nations whose citizens are unable to enjoy even elementary human rights.” In addition, by meeting such obligations and addressing these economic and social imbalances, the nations of the world served to secure a lasting peace; the encyclical argued that these imbalances were the source of conflict between nations in the modern world. ${ }^{17}$

The encyclical occasioned the division of American Catholics along ideological lines, especially with its economic concerns. The Catholic journal Commonweal noticed this division, stating that the encyclical's focus upon the underdeveloped areas of the world, and their corresponding relationship with prosperous nations, had "attracted [the] most newspaper attention" within the States, which had "stressed the fact that the Pope was not speaking ex cathedra - that the encyclical does not define a doctrine of faith or morals that binds Catholics under pain of sin." The journal believed this reluctance to declare the encyclical ex cathedra was beneficial to the conversation it was promoting, since there had been "in some circles too much tendency to create a 'Catholic party line' on social questions." However, it warned its readership that "this approach could be pushed too far, since the encyclical represented "a solemn application of traditional Catholic principles to the problems of our day, and this by the successor of St. Peter." Consequently, Commonweal warned that the encyclical had "to be regarded with

\footnotetext{
${ }^{17}$ Ibid.
} 
the utmost gravity," and argued that simply because "Mater et Magistra is not ex cathedra," did not "mean that the principles it enunciates can be lightly dismissed or easily evaded." "18

In an effort to respect the gravity of Pope John's work, the journal commented that the encyclical was quite complex, stating that it was "the longest in history, and... [and that] it will be studied and discussed for years to come. Like all the social encyclicals, the principles contained in "Mother and Teacher" are not easily absorbed in one reading; like all the social encyclicals, there is frequently more in the new work than at first meets the eye." In its own reading of the encyclical, Commonweal believed it echoed "the spirit of Pope Leo XIII," arguing that the work emphasized the primacy of the spiritual life while rejecting both materialism and communism. Along these lines, it believed the encyclical issued "a clear call for increased efforts on behalf of social justice." Consequently, the journal argued that the encyclical was "a historic landmark in Christian efforts to apply immutable principles to the changing conditions of the modern world." 19

Commonweal's assessment anticipated the sentiments expressed by The National Review, which published its commentary the following day. The editor of the journal, William Buckley F. Buckley, Jr., had established his reputation as a conservative soon after his graduation from Yale University, having published God and Man at Yale in $1951 .{ }^{20}$ As editor of the Review, he described the encyclical as a "large and sprawling document," and questioned whether or not the encyclical would later "be considered central to the social teachings of the Catholic Church; or, like Pius IX's Syllabus of Errors... it may become the source of embarrassed explanations." Ultimately, Buckley dismissed the encyclical. He argued that it had "to strike many as a venture

\footnotetext{
${ }^{18}$ Edward S. Skillin, “Week By Week: The New Encyclical,” Commonweal, July 28, 1961, 412.

${ }^{19}$ Ibid.

${ }^{20}$ God and Man at Yale argued that the administration of Yale had promoted both atheism and collectivism, and had fired faculty who sought to preserve what he considered to be Yale's traditional values (Douglas Martin, "William F. Buckley Jr., 82, Dies; Sesquipedalian Spark of Right,” The New York Times, Feb. 28, 2008).
} 
in triviality coming at this particular time in history," especially since it made scarce reference not only to communism, but also to "the extraordinary material well-being that such free economic systems as Japan's, West Germany’s, and our own are generating." ${ }^{21}$ Following up on his initial treatment, Buckley later noted that the encyclical had generated the following response in "Catholic conservative circles: 'Mater $\underline{\text { si, Magistra no.". }}$."22 Simply put, a cross-section of American Catholics had decided to ignore the teaching of the Church in matters of economic policy. $^{23}$

Buckley's commentary generated response in kind by the editor in chief of the Jesuit journal America, Fr. Thurston N. Davis. ${ }^{24}$ He charged that it took "a daring young man [at the age of 35] to characterize a papal document as "a venture in triviality," even more so his comparison of the encyclical to the Syllabus of Errors. Noting Buckley's influence among a "large and enthusiastic following," he questioned whether those in "conservative Catholic circles" might have "been fonder still of Mr. Buckley and of his program of 'conservatism' if he showed signs of comprehending an old, old conservative adage: Qui mange du pape, en meurt." 25 In a later article, America defended the encyclical by examining the "Pope's right, as Pope, to take a stand with respect to modern social problems," since it was "clear that this right of the Supreme Pontiff is not yet accepted and acknowledged on all sides. ${ }^{, 26}$ The right of the papacy to address such matters did not depend upon the doctrinal expression of ex cathedra, for an "encyclical is one of the means by which the Pope exercises his ordinary teaching mission as

\footnotetext{
${ }^{21}$ William F. Buckley, Jr., “The Week,” The National Review, July 29, 1961, 38.

${ }^{22}$ William F. Buckley, Jr., "For the Record," The National Review, August 12, 1961, 77.

${ }^{23}$ This phrase, although widely attributed to William F. Buckley Jr., was actually the response of Gary Wills, who had coined the phrase while in a phone conversation with Buckley.

${ }^{24}$ Davis also served as editor in chief of the Catholic journal, Catholic Mind, and became a consultant to the general secretary of the United States Catholic Conference in 1970 (Joan Cook, "Rev. Thurston N. Davis Dies; Edited Weekly Jesuit Journal," The New York Times, September 19, 1986).

${ }^{25}$ Thurston N. Davis, "William F. Buckley Jr.," America, August 19, 1961, 625.

${ }^{26}$ Thurston N. Davis, "Magistra, Si," America, September 30, 1961, 820.
} 
head of the Church and Vicar of Christ on earth." This did "not mean that each and every paragraph... is to be treated with equal gravity," but that "taken as a whole, the document deserves and exacts respect as an authentic guide for Catholic consciences." This was made clear in Mater et Magistra, which stated that " when the hierarchy has issued a precept or decision on a point in issue, Catholics are bound to obey their directives. The reason is that the Church has the right and obligation, not merely to guard the purity of ethical and religious principles, but also to intervene authoritatively when there is a question of judging the application of these principles to concrete cases. (Emphasis added) ${ }^{\prime 2}{ }^{27}$ This declaration harked back to Pius XI's Quadragesimo Anno, which declared "that there resides in Us the right and duty to pronounce with supreme authority upon social and economic matters... [for the Church] can in no wise renounce the duty God entrusted to her to interpose her authority... in all things that are connected with the moral law." ${ }^{28}$ From America's and Davis's perspective, the editors of The National Review denied "that there is, or could be, such a thing as a body of Christian or Catholic social teaching." ${ }^{29}$ Such a viewpoint betrayed those editors as subscribing to a "neo-secularist viewpoint," whereby an individual could "accept or reject the message of the encyclical to the degree that it squares or does not square with their personal or economic opinions. ${ }^{\prime 30}$ In the same breath, those who would attempt such a view, sought to lessen papal teaching "to the level of a secular argument. ${ }^{\prime 11}$ In light of this teaching, America upheld the encyclical as "the highest form of moral leadership," and were joined by "nations [who] have consistently welcomed the two

\footnotetext{
${ }^{27}$ Ibid., 821.

${ }^{28}$ Pius XI, "Quadragesimo Anno: Encyclical of Pope Pius XI on Reconstruction of the Social Order To Our Venerable Brethren, the Patriarchs, Primates, Archbishops, Bishops, and Other Ordinaries in Peace and Communion with the Apostolic See, and Likewise to All the Faithful of the Catholic World," The Holy See, http://www.vatican.va/holy_father/pius_xi/encyclicals/documents/hf_p-xi_enc_19310515_quadragesimoanno_en.html (accessed 10.26.2013), quoted in Thurston N. Davis, "Magistra, Si," America, September 30, 1961, 821.

${ }^{29}$ Thurston N. Davis, "Magistra, Si," America, September 30, 1961, 821.

${ }^{30}$ Ibid.

${ }^{31}$ Ibid., 822.
} 
great forerunners of Mater et Magistra, just as they today welcome Pope John's own document." 32 Consequently, the National Review's treatment of the encyclical served as a lesson "for those who insist that National Review is an authentic voice of Catholic conservatism." The editors of America asserted that "it is not... it most certainly is not.",33

Insofar as Higgins was concerned, he too acknowledged that many American news outlets had rightfully noticed the encyclical's "approval of aid to the needy nations and of increasing State intervention in matters such as health and education." ${ }^{34}$ Such an assessment was valid, but provided only one dimension of the encyclical's social impact. Upon further study of the work, Higgins identified what he considered to be the central theme of Pope John's message, that the "virtue of social justice is universal in scope and is to be put into practice in all social and economic relations." 35 By using this as his focus, he then broke down the encyclical into four different emphases: 1) the relationship between workers and employers; 2) the relationship between the different sectors of a national economy; 3) the relationship in individual political communities between differing economic levels of development dependent upon geographical location; and 4) the relationship on the international level between countries of differing economic power and social development.

By studying these different emphases, Higgins asserted that the encyclical reaffirmed the right of workers to organize, and that the organization of workers was necessary for a sound social order. Along the same lines, he argued that the encyclical elaborated on the living wage advocated by Rerum Novarum and Quadragesimo Anno "with special emphasis on the necessity

\footnotetext{
${ }^{32}$ Ibid. These two great forerunners referred to by America were Rerum Novarum and Quadragesimo Anno. ${ }^{33}$ Ibid.

${ }^{34}$ George G. Higgins, “Pope John's ‘Activist’ Spirituality,” The Yardstick, July 24, 1961, ACUA/GGH Papers, Box 325, Folder 10.

${ }^{35}$ George G. Higgins, "Mater et Magistra" (article draft, no date), ACUA/GGH Papers, Box 326, Folder 8, 3.
} 
of gearing wages to the demands of the common good. ${ }^{\prime 36}$ Quoting Mater et Magistra, he pointed out that wages could not "be left entirely to the laws of the market, so neither can it be fixed arbitrarily; it must be determined according to justice and equity." Workers

should be paid a wage which allows them to live a truly human life and to face up with dignity to their family responsibilities; but it requires, too, that in the assessment of their remuneration regard be had to their effective contribution to the production and to the economic state of the enterprise; to the requirement of the common good of the respective political communities, especially with regard to the repercussions on the overall employment of the labor force in the entire country: as also to the requirements of the universal common good, that is, of the international communities of different nature and scope. ${ }^{37}$

This assessment of wage policy in light of the common good improved upon "the teaching of

Quadragesimo Anno by spelling out... the precise demands of the common good and by making specific reference to the requirements of the international common good." Consequently, Pope John XXIII's central principle concerning wages was his charge that social progress had to "accompany and be adjusted to economic development so that all classes of citizens can participate in the increased productivity." From Higgins's vantage, this proved Mater et Magistra to be a timely document, especially since this principle was "being violated or ignored in varying degrees not only in economically less developed countries of the world but also in those which are more prosperous and more highly developed." ${ }^{38}$

Insofar as Mater et Magistra addressed property rights, the encyclical reaffirmed them as a natural right of the individual. In particular, it reassured those who were "beginning to doubt the validity of the neutral right of private ownership," stating that there was "no reason for such a

\footnotetext{
${ }^{36}$ George G. Higgins, "Mater et Magistra" (address presented for the National Conference of Catholic Charities and the Society of St. Vincent De Paul, Atlantic City, New Jersey, Sept. 16, 1962), ACUA/GGH Papers, Box 326,

Folder 4, 10.

${ }^{37}$ Ibid.

${ }^{38}$ Ibid.
} 
doubt to persist ... The right of private ownership of goods, of productive goods inclusively, has a permanent validity, precisely because it is a natural right." 39 Yet this right to property was conditional, for the encyclical also placed equal "insistence... on the social nature and the social functions of property and on the need for a more effective distribution of property among all social classes." Consequently, the encyclical also acknowledged the right of the state to own productive industries "when they 'carry with them an opportunity too great to be left to private individuals without injury to the community at large."' Even so, the right of the State to own productive property was not absolute, however. The principle of subsidiarity enunciated by Quadragesimo Anno still governed the actions of the state in relation to private individuals. According to Higgins, this meant "that the state and other public agencies 'should not extend their ownership except where motives of evident and real necessity of the common good require it, and not for the purpose of reducing and, much less, of abolishing private property." 40

Higgins believed the encyclical's use of the term "socialization," and the corresponding interpretations it had generated, had created the most conflict within the Catholic community. It was a word, "which, to the best of [his] knowledge" had "never before appeared in a Papal document." ${ }^{41}$ Furthermore, he argued that there was "no literal equivalent for this word in the official Latin text," and asserted that "the Latin text uses at least five different expressions where the English translation uses one and the same word." ${ }^{, 2}$ Relying upon the encyclical, Higgins asserted that socialization was best understood "as the "progressive multiplication of relations in society, with different forms of life and activity, and juridical instutionalization,"” which found “its expression for the most part, not in governmental programs but in 'a wide range of groups,

\footnotetext{
${ }^{39}$ Ibid., 11.

40 Ibid.

${ }^{41}$ Ibid., 12.

${ }^{42}$ George G. Higgins, "Mater et Magistra” (article draft, no date), ACUA/GGH Papers, Box 326, Folder 8, 13.
} 
movements, associations and institutions... both within single national communities and on an international level." ${ }^{, 43}$ Narrowing this initial definition, Higgins argued that "in the context of the encyclical [it] is understood as 'the multiplication of social relationships, that is, a daily more complex interdependence of citizens, introducing into their lives and activities many and varied forms of association, recognized for the most part in private and even in public law.",44

The encyclical's presentation of socialization as a "more complex interdependence of citizens" stemmed from its recognition of the "progressive perfection of modern methods of thought-diffusion," and how "the press, cinema, radio, [and] television... makes it possible for everyone to participate in human events the world over." While this technological advancement provided many benefits in terms of communication and information, it also served to limit humanity by influencing their decisions. Correspondingly, Mater et Magistra argued that the

multiplication and daily extension of forms of association brings with it a multiplicity of restrictive laws and regulations in many departments of human life. As a consequence, it narrows the sphere of a person's freedom of action. The means often used, the methods followed, the atmosphere created, all conspire to make it difficult for a person to think independently of outside influences, to act on his own initiative, exercise his responsibility and fulfill his own personality.

Socialization was the construct by which humanity informed itself, and by doing so, also influenced the ways in which individuals made decisions. Such a force was "not a product of natural forces working, as it were, by blind impulse," but was the "creation of men who are free and autonomous by nature." This system of information and influence did not guarantee the

\footnotetext{
${ }^{43}$ George G. Higgins, "Mater et Magistra" (address presented for the National Conference of Catholic Charities and the Society of St. Vincent De Paul, Atlantic City, New Jersey, Sept. 16, 1962), ACUA/GGH Papers, Box 326, Folder 4, 12.

${ }^{44}$ George G. Higgins, "Mater et Magistra" (article draft, no date), ACUA/GGH Papers, Box 326, Folder 8, 14.
} 
welfare of humanity, which explained the Church's call for government management of it. ${ }^{45}$ Pope John believed that a "sane view of the common good" had to "be present and operative in men invested with public authority," and that governmental representatives had to "take account of all those social conditions which favor the full development of the human personality" when addressing the issue of socialization in society. Such a "sane view" was necessary, since one of the roles of government was to strike "a balance between the autonomous and active collaboration of individuals and groups, and the timely coordination and encouragement ... of these private undertakings." This did not mean that government should exert totalitarian control of such associations, but merely guide them in order to ensure that the common good remained the goal of these "numerous intermediary bodies and corporate enterprises" which were "the main vehicle[s] of this social growth" expressed in the modern age. ${ }^{46}$

Higgins worried there were three possible misinterpretations of the encyclical's definition of socialization:

The first would be to confuse socialization with socialism. The second, which is similar to the first, is to equate socialization exclusively with governmental action. The third is to equate socialization exclusively with voluntary action by non-governmental organizations or associations, thus ruling out almost every kind of governmental action." 47

Each of these interpretations failed to take into account the principle of subsidiarity advocated by Pius XI's Quadragesimo Anno. For Higgins, socialization meant that Pope John had given his "blessings, first and foremost, but not exclusively, to voluntary programs in the field of social reform and social welfare." This did not exclude the government role, however. "Governmental

\footnotetext{
${ }^{45}$ Pope John XXIII, "Mater et Magistra: Encyclical of Pope John XXIII On Christianity and Social Progress," The Holy See, http://www.vatican.va/holy_father/john_xxiii/encyclicals/documents/hf_jxxiii_enc_15051961_mater_en.html (accessed 10.26.2013).

${ }^{46}$ Ibid.

${ }^{47}$ George G. Higgins, "Mater et Magistra" (address presented for the National Conference of Catholic Charities and the Society of St. Vincent De Paul, Atlantic City, New Jersey, Sept. 16, 1962), ACUA/GGH Papers, Box 326, Folder 4, 13.
} 
programs - for example, social security — are also commended in so far as they are in harmony with the principle of subsidiarity." Consequently, Higgins believed Mater et Magistra affirmed "that 'the economic order is the creation of the personal initiative of private citizens themselves working either individually or in association with each other in various ways for the prosecution of common interests." At the same time, he noted Mater et Magistra's demand that "the public authorities must not remain inactive, if they are to promote in a proper way the productive development in behalf of social progress for the benefit of all the citizens." From Higgins's point of view, this meant that government action had to "be exercised so as to protect the essential personal rights of individuals and the rights of the family." 48 Thus, there could not " be a well-ordered and fruitful society without the support in the economic field both of the individual citizen and of the public authorities; a working together in harmony in the proportions corresponding to the needs of the common good in the changing situations and vicissitudes of human life." $" 49$

All of these aspects came into play when addressed to the cause of the Industry Council Plan that Higgins and the Social Action Department had promoted in the 1940s and 1950s. While Higgins recognized that some had "observed that Pope John XXIII seems to be less interested in the Industry Council Plan than was Pope Pius XI," he argued that such an interpretation was “only partially true." ${ }^{50}$ It was true that the encyclical "carefully avoids giving ... approval to any particular method of organizing or reorganizing economic life," and that the pope had steered clear of "using the corporative terminology of Pius XI." ${ }^{51}$ Such a choice encouraged flexibility in the discovery of a solution, however. The core principles of the Industry Council Plan still

\footnotetext{
${ }^{48}$ Ibid., 14.

${ }^{49}$ Ibid., 15.

${ }^{50}$ George G. Higgins, "Relations Between Employers and Workers Today" (address presented for the Christus Rex Congress, Galway, Ireland, April 25, 1962), ACUA/GGH Papers, Box 326, Folder 1, 16.

${ }^{51}$ Ibid., 17.
} 
remained, particularly in regard to the role of government and the existence and interaction of voluntary associations with government. Voluntary associations remained an integral part of any economic system, and served as a check against the threat of government totalitarianism. In this respect the encyclical supported the social encyclicals that came before it, arguing that the principle of subsidiarity had to remain the governing principle, whereby governments and voluntary associations worked together to serve the common good of their citizens. Mater et Magistra simply changed the proposed means by which such a system could (or should) exist. Rather than attempt to set up a structured system through the encyclical - as Pope Pius had done through Quadragesimo Anno with the Industry Council Plan - Pope John preferred to let those more experienced in economic matters undertake such a task. By allowing them to do so, the encyclical acknowledged that the varying governments of the world might require different stratagems and methods necessary to implement a system based upon such principles. Mater et Magistra thus reaffirmed the core principles of the Industry Council Plan, while at the same time freeing its proponents from the confines that Quadragesimo Anno had advocated towards its implementation. From Higgins' vantage, Pope John XXIII's approach thus served as a “timely corrective" for those whose "approach and ... terminology has been a little too inflexible."52 Nevertheless, the tenets of the Industry Council Plan remained as a key component in the social agenda of the Church. ${ }^{53}$

\footnotetext{
${ }^{52}$ Ibid., 19, 18.

${ }^{53}$ In regard to The National Review controversy, Higgins interpreted the conflict in the same light as he did that of the principle of subsidiarity. Higgins warned both sides of the conflict, acknowledging that the encyclical served as a bulwark for Catholic liberals seeking to justify an increased role of government in economic life, but at the same time cautioning those of the left who "concentrate[d] so heavily on the encyclical's qualified support of government action as to ignore the Holy Father's repeated emphasis on the principle of subsidiarity and his reaffirmation of the central point of Quadragesimo Anno, namely, that 'men should strive to achieve a national and international juridical order, with a complexus of public and private institutions, inspired by social justice, and to which the economic sector should be conformed, thus making it less difficult for economic agents to carry out their tasks in conformity to the demands of justice within the framework of the common good." Ultimately, Higgins reminded both sides that "while the public authorities 'must not remain inactive', it [was] not their function to replace the free
} 


\section{Mater et Magistra and the Lay Apostolate}

For Higgins and his social agenda, particularly that of the Industry Council Plan, Mater et Magistra only served to reaffirm the social principles that Rerum Novarum and Quadragesimo Anno had promoted for years. This restatement of social principles was not the only aspect of the encyclical upon which Higgins focused, however, nor was it the most significant part of the document. Rather, Higgins believed the encyclical's treatment of the laity, and their corresponding role within the Church, was "the most important section of the entire document." He argued that Mater et Magistra presented a religious view of the apostolate by which the "layman can sanctify himself in and through his work," a view which Higgins justified by Pope John's reminder "that at the Last Supper, Our Lord asked not that His apostles be taken out of the world but that they be delivered from evil." ${ }^{54}$ Higgins understood this as an affirmation of his earlier work promoting a liturgical foundation for lay Catholics through the theology of Virgil Michel. Further investigation of the encyclical led Higgins to declare that its key passage was the assertion that no man should "imagine a life of activity in the world [that] is incompatible with spiritual perfection. The two can very well be harmonized." The document even went so far as to claim that it was a "gross error to suppose that a man cannot perfect himself except by putting aside all temporal activity, on the plea that such activity will inevitably lead him to compromise his personal dignity as a human being and as a Christian." ${ }^{, 55}$ Much to

\footnotetext{
initiative of individuals and voluntary groups but rather to 'direct, stimulate, coordinate, supplement, and integrate' the activities of individuals and groups in interest of the common good" (George G. Higgins, "Mater et Magistra Its Implications for the Charitable Work of the Church" (address presented for the National Conference of Catholic Charities and the Society of St. Vincent De Paul, Atlantic City, New Jersey, Sept. 16, 1962), ACUA/GGH Papers, Box 326, Folder 4, 15).

${ }^{54}$ George G. Higgins, “Pope John's ‘Activist' Spirituality,” The Yardstick, July 24, 1961, ACUA/GGH Papers, Box 325, Folder 10.

${ }^{55}$ Pope John XXIII, "Mater et Magistra: Encyclical of Pope John XXIII On Christianity and Social Progress," The Holy See, http://www.vatican.va/holy father/john xxiii/encyclicals/documents/hf_jxxiii_enc_15051961_mater_en.html (accessed 10.26.2013).
} 
Higgins' pleasure, he argued that such a view refuted "a certain group of spiritual writers" who claimed that while "the modern apostle must venture forth into 'the big, bad world' ... they claim he should scamper back to the safety of his private prayer as soon as possible. For they say his real life is his prayer life and that his activity in the world, in itself, is just a kind of necessary evil." Instead, the encyclical clarified the Church's mission in the world, which was the "humanizing and Christianizing [of] the world through the laity." 56

Given Higgins's emphasis upon Virgil Michel and the liturgical movement in the years prior to Mater et Magistra, it should come as no surprise that Higgins promoted an apostolate which relied upon the activity of the laity within their secular institutions to Christianize the modern world. Such a view worked within the liturgical paradigm he had promoted through Michel's exposition of the Mass, and its influence upon the members of the Church. Naturally, Catholic organizations were a necessary part of this apostolate, but Higgins did not believe these organizations should be the primary focus of it. The family apostolate served as a general example in this regard, which he considered to be "the most popular type of lay activity" for the time period. ${ }^{57}$ Consequently, while Higgins supported the family apostolate, he used it to demonstrate its limited effectiveness when it came to lay social action.

Without naming any particular Catholic organizations, Higgins acknowledged that the family apostolate served an important purpose, and through such efforts local communities were "being Christianized, starting with the basic one, the home, and reaching to the parish and all the more or less sporadic communities which have been created to answer some specific need." 58

\footnotetext{
${ }^{56}$ George G. Higgins, “Pope John's ‘Activist' Spirituality,” The Yardstick, July 24, 1961, ACUA/GGH Papers, Box 325 , Folder 10.

${ }^{57}$ George G. Higgins, "The Apostolic Catholic in a Changing World" (address presented for the Sixth Annual Family Life Institute, Seton Hall University, South Orange, New Jersey, Oct. 18, 1959), ACUA/GGH Papers, Box 325 , Folder 5, 1.

${ }^{58}$ Ibid.
} 
And while such work was praise-worthy, Higgins warned that it might encourage Catholics "in the name of family virtue [to] overlook a great number of problems which go beyond the scope of the family and cannot be reached by a specifically family apostolate. ${ }^{, 59}$ If Catholics took such a path, then the lay apostolate would never amount to anything more than a

bourgeois type of movement which would give people the feeling that they are doing something very important because they are welding little families together and solving family problems on the local level but which would leave them unaware of and uninterested in the broader social problems which the family unit by itself is in no position to solve. ${ }^{60}$

In other words, the family apostolate presented a real danger that "people might get the impression that family groups are all that is needed to solve social problems, whereas, actually, most of the social problems with which we deal in our offices in the labor field or in the field of international relations, for example, are quite incapable of solution by family organizations. ${ }^{61}$

As Higgins saw it, "many ... Catholics at the present time, including some of those who are in specialized groups are not carrying their proper share of the load in secular organizations outside the family group." This included those Catholics in the labor movement, who had "derived their idealism, such as it is, from some source other than the specialized groups of the lay apostolate." ${ }^{, 62}$ Such a warning was not meant to dissuade Catholics from participating in the family apostolate, but rather to redirect the energies of the family apostolate towards the greater problems within society. Higgins advocated that the family apostolate had to engage the modern world on a larger scale, rather than be content to remain focused on the local level. To this end, the family apostolate could readily serve to prepare Catholics for social work in the secular world outside the local Catholic community. Thus, for Higgins, the purpose of the family

\footnotetext{
${ }^{59}$ Ibid., 2.

${ }^{60}$ Ibid.

${ }^{61}$ Ibid.

${ }^{62}$ Ibid., 3.
} 
apostolate was to raise "the sights of the people within the movement," and to make "them aware of the responsibilities which go beyond the family field," while at the same time "instilling in them some kind of desire to go into other groups, which alone can solve those problems." ${ }^{63}$ In other words, the family apostolate was an element of the greater apostolate to the modern world, and was meant to train Catholics to be "ready to go out and work in the larger fields of the social and economic order and help do the job which family organizations cannot be expected to accomplish." ${ }^{64}$ Instead of insulating Catholics from the greater world around them, Higgins sought to integrate them with society in the hopes of achieving a greater goal for the common good.

The involvement of the laity in a greater social apostolate was essential, since Higgins believed that the lay members of the Church were the only ones who could accomplish such change in the temporal world. He was not alone in this belief either, citing Cardinal Emmanuel Célestin Suhard, the former Archbishop of Paris who helped found the Worker-Priest movement, in support. Suhard, along with Higgins, believed that the

fact of the matter is ... that only the laity are present to the human city, because they live in it and are in continuous and immediate contact with its factories, houses, and neighborhoods. But their irreplaceable role is not only, or mainly, on this account. It stems from their vocation. Placed by God at the head of a family or of some enterprise, or following a profession, they have the vocational obligation of bringing these things to their proper ends and of infusing a Christian spirit into them. ${ }^{65}$

Consequently, Higgins believed that "these problems are directly the responsibility of the layman and only indirectly the responsibility of the priest." Citing an unnamed American theologian, Higgins argued that hierarchical authority could

\footnotetext{
${ }^{63}$ Ibid.

${ }^{64}$ Ibid, $4-5$.

${ }^{65}$ Ibid., $7-8$.
} 
not and cannot initiate such reforms. It is the function of authority to supervise and regulate, to point out excesses and dangers and to encourage the downtrodden to hope and to struggle for a better day. Social reforms, if they are to be effective and lasting, must come from below: they cannot be imposed from above. It is the vocation of the laity to take this initiative, with the aid and blessing of God. ${ }^{66}$

Higgins maintained a similar stance when it came to Catholic social organizations that fell outside the purview of the family apostolate. He argued that "the primary role of Catholic organizations in the field of social reform - at least in a pluralistic society such as our own - is to help prepare their members for more effective apostolic action in the secular world.” Lay Catholics and their corresponding organizations "in the field of social reform should not be thought of as a substitute for trade unions, employers' organizations, professional associations, political parties, or what have you. On the contrary, the effectiveness of a Catholic lay organization in the social apostolate should be measured, normally, not so much by the scope of its own action programs in the field of social reform, but rather by the involvement of its members in the above mentioned secular organizations and by their success in helping these secular organizations to develop more effective programs of their own." ${ }^{67}$ Much like his concern for the family apostolate, Higgins asserted that "traditionally there has too often been a tendency to think of the lay apostolate almost exclusively in terms of membership in a Catholic organization, and a parallel tendency to judge the Catholicity of the individual layman by the degree of his involvement in Catholic organizations rather than by the effectiveness of his apostolate in secular society.",68

Such a view betrayed the spirit of Mater et Magistra, for social change could only take place if Catholics participated in the temporal world. The separatist subculture that had been part

\footnotetext{
${ }^{66}$ Ibid., 8.

${ }^{67}$ George G. Higgins, "Lay Apostolate in the Secular World," The Yardstick, March 30, 1964, ACUA/GGH Papers, Box 348, Folder 5.

${ }^{68}$ Ibid.
} 
and parcel to the American Catholic experience had to end. For Higgins, this was the primary message of the encyclical. Fortunately for American Catholics, American unions stood as one of the primary means of participation with the modern world. Higgins argued that Pope John's encyclical "solemnly reaffirms the traditional teaching of the Church to the effect that unions are not only desirable but necessary," and that the "Holy Father simply takes it for granted - almost as though it were self-evident truth - that the organization not only of workers but also of employers is absolutely essential if we are ever to bring labor-management relations into more human balance." ${ }^{\prime 69}$ This goal towards a more human balance required a view beyond the ends of the union itself, however. The organization of a particular workforce was a means to an end, but could not be the only end for a particular union. Rather, the encyclical called for unions to pursue the greater purpose of "the common good or the general welfare of society as a whole." If unions were to serve the common good, this meant they had to organize "primarily as a means through which their members can cooperate with the members of other organized groups in an effort to bring about a more truly human life for all our people." ${ }^{70}$ Unions were not the only organizations that might serve such ends, however. Higgins consistently argued that the Church solidly lined up with those associations which were "honestly striving to promote the cause of social justice by methods or means which are consistent with Christian principles," which just as easily could have been employers' associations as it was unions. Such was the call of the Catholic laity, for by focusing on the greater good of society within their own secular institutions Catholics answered their vocation as a lay member of the Church. Consequently, the lay apostolate was not limited solely to the working class of Catholics.

\footnotetext{
${ }^{69}$ George G. Higgins to John G. Ramsey, June 26, 1962 (correspondence contains the article "Religion Speaks to Labor," written by Higgins for the United Steelworkers of America), ACUA/GGH Papers, Box 326 Folder 3, 1. ${ }^{70}$ Ibid., 3.
} 
This interpretation of the encyclical was contested, however, for others questioned whether Mater et Magistra truly endorsed secular unions, or whether it merely tolerated them. As Higgins understood the controversy, those opposed to this understanding of unions in relation to the social apostolate argued the existence of two different types of unions: "those that carry on their activities in more or less explicit accord with the principles of Christian teaching and (2) those that follow the natural law and respect the liberty of individuals in religious and moral questions." 71 The dispute rested then on whether "or not Pope John meant to favor or to give preferential status to the so-called Christian unions." ${ }^{, 72}$ According to Higgins, Mater et Magistra never actually used the term "Christian union.” Instead, Higgins argued that the encyclical endorsed professional organizations and trade unions, which are based upon Christian principles. This assertion was based upon the interpretation of Fr. Oswald von Nell-Breuning, one of the main contributors to Quadragesimo Anno, and an authority in the field of social justice. ${ }^{73}$ Undoubtedly, Higgins believed that American unions met both Pope John XXIII's and NellBreuning's qualification. Mater et Magistra made this clear as well, in that it gave "equal praise to 'those dear sons of ours who, imbued with Christian principles, give their special attention to other labor associations and those groups of workingmen that follow the laws of nature and respect the religious and moral liberty of individuals.",

The question remained, however, as to whether such an interpretation was the correct one. There were those who believed otherwise, particularly that of an unnamed Latin American

\footnotetext{
${ }^{71}$ George G. Higgins, “Two Types of Unions,” The Yardstick, Feb. 17, 1964, ACUA/GGH Papers, Box 348, Folder 5. studied and received his doctorate from the Gregorian University in Rome, and served as an advisor to Pope Pius XI. In so far as social theology is concerned, Nell-Breuning was best known for his contributions to the composition of Quadragesimo Anno.

${ }^{74}$ George G. Higgins, "Mater et Magistra” (article draft, no date), ACUA/GGH Papers, Box 326, Folder 8, 7.
} 
trade unionist who had labeled Higgins as "Yankee imperialist" for his views on the subject. This same trade unionist also argued that "Father Nell Breuning really doesn't know what he is talking about" in regards to the issue. ${ }^{75}$ Besides this personal assault, Fr. John E. Coogan, S.J, a professor in sociology at Xavier, Cincinnati, had separately circulated a pamphlet titled "Rome and the American Labor Union." Coogan argued that the Holy See had never officially approved of secular unions, but only those unions of official Catholic status. Accordingly, American unions were "essentially inadequate" when compared to Catholic social teaching, particularly the teaching found within Mater et Magistra. ${ }^{76}$ The matter would remain unsettled until the promulgation of Gaudium et Spes during the Second Vatican Council. In its absence, the encyclical Pacem in Terris would contribute to Higgins' understanding of the social apostolate and its role within the Church.

\section{The Opening of the Council and Pacem in Terris}

As a member of the preparatory Commission on the Lay Apostolate, Higgins had been informed that all members of the preparatory commissions would be invited to serve as periti at the Council. However, when his preparatory commission had its final meeting, the members had been informed that an official decision would be made that summer prior to the start of the Council. Consequently, he immediately set out to secure a position at the Council upon his return to the U.S. His first step was to write Msgr. Luigi G. Ligutti, the former president of the National Catholic Rural Life Conference and a fellow preparatory commission member, who was still residing in Rome. Higgins asked Ligutti to determine whether the members of the

\footnotetext{
${ }^{75}$ George G. Higgins, "Two Types of Unions," The Yardstick, Feb. 17, 1964, ACUA/GGH Papers, Box 348, Folder 5.

${ }^{76}$ George G. Higgins, "U.S. Unions Guided by Christian Principles," The Yardstick, April 22, 1963, ACUA/GGH Papers, Box 348, Folder 2.
} 
preparatory commission would be invited to attend the Council as periti, and if not, whether there would be any objection to members of the preparatory commissions serving as consultants to bishops. Higgins had received invitations from Bishop Coleman Carroll of Miami, FL as well as that of Ernest Primeau of Manchester, $\mathrm{NH}$, to serve as a consultant, but needed to determine if he might still be invited to serve as a peritus. ${ }^{77}$ Higgins even went so far as to contact Msgr. Achille Glorieux, the Secretary for the preparatory Commission on the Lay Apostolate, about the matter, who advised him to accept Carroll's invitation with the understanding that his invitation as a peritus could still be forthcoming. ${ }^{78}$ By October 12, 1962, the issue had been resolved. Writing home, Higgins told his parents that "we have our credentials finally... and they are worth their weight in gold.... I will be able to attend any and all sessions of the council.,79 Higgins had been named a peritus.

As a peritus, Higgins served as a member of the Commission of the Lay Apostolate, which was responsible for the schema which led to the Council's Decree on the Apotolate of the Laity, Apostolicam Actuositatem. Yet, this was not the only commission to which he belonged. In January of 1963, he also joined the mixed commission composed of members from both the Doctrinal Commission and the Commission on the Apostolate of the Laity, which was responsible for the development of the schema which culminated in the Council's Pastoral Constitution of the Church, Gaudium et Spes. However, it should be noted that he also performed a number of duties outside of this role for the American Church. One in particular was his

\footnotetext{
${ }^{77}$ According to the correspondence between them, Ligutti honored Higgins's request and even suggested that Higgins contact Cardinal Cicognani, the former Apostolic Delegate to the United States and the current Vatican Secretary of State, about the matter by way of Archbishop of Washington, D.C., Patrick O'Boyle. Higgins declined this suggestion, stating O'Boyle would be reluctant to take such action, since like "most Americans, they [the bishops] are rather timid about making requests of the Vatican" (George G. Higgins to Luigi G. Ligutti, September 21, 1962, ACUA/GGH Papers, Box 36, Folder 15).

${ }_{78}^{7}$ George G. Higgins to Msgr. Paul F. Tanner, August 22, 1962, ACUA/GGH Papers, Box 70, Folder 2.

${ }^{79}$ George G. Higgins to Charles Higgins, Oct 12, 1962, ACUA/GGH Papers, Box 426, Folder 13.
} 
participation in the American bishops' press panel, which offered daily updates on the events of the Council to reporters. As a member of this panel, Higgins sought not only to keep reporters informed of the proceedings of the Council, but to assure them that the bishops were not censoring information from the press, as reporters were unable to attend its meetings. Besides this, Higgins also acted as a liaison to the American bishops for Cardinal Augustin Bea, the President of the Secretariat for Christian Unity. Bea contacted Higgins through his assistant, Malachi Martin, hoping that Higgins could inform him who among the American hierarchy might favor his work on the Schema on Non-Christian Religions and its statement on the Jews. ${ }^{80}$ As a result, Higgins served as an intermediary between Bea and the American bishops, as well as that of the American Jewish community who sought to influence its development. ${ }^{81}$

As a member of the Commission of the Lay Apostolate, and later that of the mixed commission, Higgins focused on the role of the laity and its social apostolate within the Church. However, soon after his introduction to the Council, he was once again influenced by another encyclical of Pope John XXIII. Published on April 11, 1963, Pacem in Terris broke new ground by addressing "all men of goodwill," as opposed to simply the faithful of the Catholic Church. This address to "all men" had been made once before by the Pope during his radio address on October 25 of that year, just days after the opening of the Second Vatican Council. At that time, he had called for "peace and brotherhood of all men," as the world faced the threat of nuclear

\footnotetext{
${ }^{80}$ Besides serving as Cardinal Bea's personal assistant, Malachi Martin was a professor of paleontology at the Pontifical Biblical Institute in Rome. He would later move to New York, and work such odd jobs as a taxi driver and dishwasher, while he focused on his writing. He was perhaps best known for his work on demonic possession and exorcism, Hostage to the Devil (Eric Galati, "Malachi Martin: A Renowned Biblical Scholar, He Clashed with the Hierarchy on the Role of the Roman Catholic Church," The Guardian, August 9, 1999, http://www.theguardian.com/news/1999/aug/10/guardianobituaries3 (accessed 10.25.2013)).

${ }^{81}$ This relationship between Bea, Martin and Higgins is explored in greater detail in the following chapter. It was through this relationship that Higgins became involved in the development of Nostra Aetate, and in its implementation within the United States after the Council had concluded.
} 
during the throes of the Cuban Missile Crisis. ${ }^{82}$ Almost five months later, the Pope expanded upon this call to peace. The title of the encyclical, translated in English as "Peace On Earth," expressed its hopes for the world in a tumultuous age. As a work, the encyclical recognized the importance of human dignity and defined the rights associated with it. With these principles clarified, it then integrated them in its call for international peace. It was the first time that a Pope had described the rights of humanity in such language, and it had a marked impact upon Higgins's efforts to define the role of the laity within the social apostolate.

Then encyclical consisted of five sections: 1) the basis for order between men; 2) the proper relationship between the individual and the State as a public authority; 3) the proper relationship between states; 4) the interdependence of states in the current age; and 5) the pastoral exhortations of the papacy. Pope John asserted that order between men had to be founded upon the recognition of the individual as a person, which conveyed certain rights. Each "individual man is truly a person. His is a nature... endowed with intelligence and free will. As such, he has rights and duties, which together flow as a direct consequence from his nature. These rights and duties are universal and inviolable, and therefore altogether inalienable." ${ }^{~} 83$ Primary among these rights was the right to live and to be respected. Man "has the right to bodily integrity and to the means necessary for the proper development of life," and moreover, "has a right to his good name. He has a right to freedom in investigating the truth, and - within the limits of moral order and the common good - to freedom of speech and publication, and to freedom to pursue whatever profession he may choose." 84 While these rights were guaranteed to

\footnotetext{
82 “Text of Pope's Appeal," New York Times, October 26, 1962.

${ }^{83}$ Pope John XXIII, "Pacem in Terris: Encyclical of Pope John XXIII on Establishing Universal Peace in Truth, Justice, Charity, and Liberty," The Holy See,

http://www.vatican.va/holy_father/john_xxiii/encyclicals/documents/hf_j-xxiii_enc_11041963_pacem_en.html (accessed 10.25.2013).

${ }^{84}$ Ibid.
} 
man, the encyclical recognized that human "society can be neither well-ordered nor prosperous without the presence of those who, invested with legal authority, preserve its institutions and do all that is necessary to sponsor actively the interests of all its members." Individuals of the state then were subject to this authority, but Pope John reminded his audience that the authority of the State was granted by God. In turn, this meant that the purpose of the State was to promote the cause of the common good. In this manner the authority of the State was "before all else a moral force," and it was for this "reason the appeal of rulers should be to the individual conscience, to the duty which every man has of voluntarily contributing to the common good." 85 Such an appeal was a practice in sound judgment for "no man has the capacity to force internal compliance on another. Only God can do that, for He alone scrutinizes and judges the secret counsels of the heart." $" 86$

Even further, Pacem in Terris applied the same principles in its discussion of state relationships as it did in regards to individual dignity and human rights. From Pope John's perspective, state relationships had to "be harmonized in accordance with the dictates of truth, justice, willing cooperation, and freedom," since the "same law of nature that governs the life and conduct of individuals must also regulate the relations of political communities with one another." ${ }^{87}$ Much like individuals then, all states had "the right to existence, to self-development, and to the means necessary to achieve this. They have the right to play the leading part in the process of their own development, and the right to their good name and due honors." It was their place to "safeguard all such rights effectively, and to avoid any action that might violate them.

\footnotetext{
${ }^{85}$ Ibid. Pope John XXIII applied these teachings to his understanding of constitutional democracies as well. He argued that the "fact that authority comes from God does not mean that men have no power to choose those who are to rule the State, or to decide upon the government they want, and determine the procedure and limitations of rulers in the exercise of their authority. Hence the above teaching is consonant with any genuine democratic form of government" (Ibid).

${ }^{86}$ Ibid.

${ }^{87}$ Ibid.
} 
And just as individual men may not pursue their own private interests in a way that is unfair and detrimental to others, so too it would be criminal in a State to aim at improving itself by the use of methods which involve other nations in injury and unjust oppression." Consequently, the encyclical called for the governments of the world to put aside those practices based on fear and injustice, which included the arms race that was then underway. Such an arms race, justified under the belief "that under modern conditions peace cannot be assured except on the basis of an equal balance of armaments," only resulted in the populace of the world "living in the grip of constant fear ... that at any moment the impending storm may break upon them with horrific violence." Rather than govern by fear, the encyclical called for the nations of the world to govern under a principle of love. Such a demand explained the encyclical's call for the governments of the world to take the "positive steps to pool their material and spiritual resources," which could "be achieved by all kinds of mutual collaboration." Fortunately, the pope believed it was "already happening in our day in the economic, social, political, educational, health and athletic spheres. ${ }^{98}$ While such collaboration would help solve some of the problems of the modern world, this did not address those problems that were "world-wide in their dimensions." The extent of such problems could only be solved "by a public authority with power, organization and means co-extensive with these problems, and with a world-wide sphere of activity." As a result, Pacem in Terris challenged the traditional notions of absolute sovereignty, and advocated a greater role of the United Nations in the management of world peace.

The encyclical concluded with pastoral exhortations urging Catholics to work with nonCatholics on an individual and corporate basis for the advancement of the common good. It was this section, and the principles which Pacem in Terris promoted, that Higgins found most useful in his effort to advocate the social apostolate. Quoting the encyclical, Higgins highlighted that its

${ }^{88}$ Ibid. 
"basic principle" was "that "every human being is a person, that... his nature is endowed with intelligence and free will,"” and that due to man's nature "every human being 'has rights and duties of his own, flowing directly and simultaneously from his very nature, which are therefore universal, inviolable and inalienable." 89 Among these rights stood the ability to "worship God in accordance with the right dictates of his own conscience, and to profess his religion both in private and public." ${ }^{90}$ These two principles demonstrated what the encyclical hoped to achieve, which was "to indicate some of the principal steps that can and must be taken by all men of good will - and not merely by Catholics - if we are ever going to enjoy the blessing of universal peace in 'truth, justice, charity, and liberty." "91 Such a peace required all of mankind, regardless of religious belief, to cooperate with one another towards the greater common good. Insofar as Catholics were concerned, it freed them to work within their secular institutions among nonCatholics. Higgins contended that Pacem in Terris was quite clear on this subject; Catholics "must be willing to cooperate with other men of good will and must allow that they are animated by a spirit of understanding and detachment and disposed to work loyally for the common good." 92

Higgins feared that far too many American Catholics were "lagging behind the Holy Father's leadership in this regard," that American Catholics were not "actively participating in worthwhile non-sectarian... peace organizations," let alone social organizations. ${ }^{93}$ Fortunately for Higgins, Pacem in Terris did not provide the last word on the subject. Higgins would continue to promote his understanding of the social apostolate during his time as a peritus at the

\footnotetext{
${ }^{89}$ George G. Higgins, "Peace on Earth,” April 17, 1963, ACUA/GGH Papers, Box 326, Folder 5, 2 - 3.

${ }^{90}$ Pope John XXIII, "Pacem in Terris: Encyclical of Pope John XXIII on Establishing Universal Peace in Truth, Justice, Charity, and Liberty," The Holy See, http://www.vatican.va/holy_father/john_xxiii/encyclicals/documents/hf_j-xxiii_enc_11041963_pacem_en.html (accessed 10.25.2013).

${ }^{91}$ George G. Higgins, "Peace on Earth,” April 17, 1963, ACUA/GGH Papers, Box 326, Folder 5, 2.

${ }^{92}$ Ibid., 7.

${ }^{93}$ Ibid.
} 
Second Vatican Council, particularly through his work for the mixed commission. His efforts were well rewarded, for the Council's Constitution of the Church in the Modern World, Gaudium et Spes, determined both the place and the role of the laity within the Church, which included their involvement in secular organizations.

\section{The Pastoral Constitution of the Church in the Modern World: The Council's Affirmation of Mater et Magistra and Pacem in Terris}

As a peritus who worked on the Pastoral Constitution of the Church in the Modern World, Higgins interpreted the mixed commission's efforts as the same as those found in Mater et Magistra and Pacem in Terris. Following the Council, he noted that much like Pacem in Terris, the Constitution addressed the whole of humanity, rather than the Church alone. Similar to that encyclical, the Constitution also addressed the dignity of the human person, and the inalienable rights associated with it. He argued that the Constitution, particularly in its treatment of social and economic issues, offered "nothing substantially new or original about either of these matters," and instead preferred to paraphrase "the teaching of the social encyclicals, notably Mater et Magistra. ${ }^{.94}$ And since the Constitution followed the tone and tenor of both Mater et Magistra and Pacem in Terris, it too was pastoral in its scope and presentation. As a consequence, Higgins argued that the Pastoral Constitution of the Church never intended to present a new social theology for the Catholic Church, but rather served "to indicate how the Council conceived of the purpose and the activity of the Church in the modern world. ${ }^{, 95}$ This was not to imply that the Pastoral Constitution did not present new emphases on social and

\footnotetext{
${ }^{94}$ George G. Higgins, "Address on the Constitution on the Church in the Modern World: Social and Economic Life" (address presented to the Conference on the Main Theological Issues of Vatican Council II, University of Notre Dame, Indiana, March 25, 1966), ACUA/GGH Papers, Box 327, Folder 6, 7.

${ }_{95}$ George G. Higgins, "The Vatican Council's Constitution on the Church in the Modern World" (address presented to the Annual Convention of the National Catholic Social Action Conference, Washington, D.C., Aug. 27, 1966), ACUA/GGH Papers, Box 327, Folder 6, 5.
} 
economic issues, but rather that the intent of the document was to serve "primarily ... [as] a synthesis or bringing up-to-date of Catholic teaching." 96 Along these same lines, Higgins asserted that the Pastoral Constitution did "not pretend to break any new ground in the field of Catholic social teaching." Instead, he maintained that it was "simply a brief restatement ... of some, but by no means all of the key principles and ideals outlined in papal social pronouncements of the past 75 years." 97 In this sense, the issues of the Constitution confronted were the same problems found in the social encyclicals that preceded it: the "lack of balance between social classes, between various sectors of economic life, between particular regions of individual countries, and between rich and poor nations - these and other inequalities ... [that] seriously jeopardize the peace of the world." 98

While the Church addressed these social ills and concerns, Higgins argued that the Constitution did not present the Church as the sole arbiter of these social problems. As a pastoral document, it did not seek to "say the last word on current problems from the point of view of Catholic theology." Instead, it desired "to call attention to certain practical steps that men of good will can take to make the world a better place in which to live." 99 Higgins believed that in many ways the Pastoral Constitution of the Church purposefully limited its role in these affairs, and that it had done so because it acknowledged that the problems the Church faced were "highly contingent matters which are in a constant state of development and consequently do not lend themselves readily to a univocal and definitive application of moral principles." ${ }^{100}$ Consequently, the answers to these social problems could only be provided by "informed and zealous laymen -

\footnotetext{
96 Ibid., 6.

${ }^{97}$ Ibid., 8.

${ }^{98}$ George G. Higgins, "Address on the Constitution on the Church in the Modern World: Social and Economic Life" (address presented to the Conference on the Main Theological Issues of Vatican Council II, University of Notre Dame, Indiana, March 25, 1966), ACUA/GGH Papers, Box 327, Folder 6, 5.

${ }^{99}$ George G. Higgins, "Pastoral Constitution on the Church in the Modern World," April, 1967, ACUA/GGH Papers, Box 328, Folder 1.

${ }^{100}$ George G. Higgins, “Address on Schema 13,” 1967, ACUA/GGH Papers, Box 328, Folder 4, 2.
} 
laymen who are at once technically competent and adequately instructed in the principles of social ethics and theology and who have a deep and abiding love for the world and are persuaded that their very Christian calling leaves them no choice but to be deeply concerned about the problems with which the world is presently confronted." ${ }^{101}$ And since the Constitution spoke to "all men," its aim was to present the moral principles and ideals that would inspire and guide all of humanity in those efforts.

Ultimately Higgins believed that it was the Dogmatic Constitution of the Church, Lumen Gentium, that served as the lynchpin for understanding Gaudium et Spes and Apostolicam Actuositatem. During his time as a peritus, Higgins argued that the Dogmatic Constitution was the essential document in understanding all the decrees of the Council, since this document focused on the nature of the Church itself. Speaking as a peritus of the Council in 1964, Higgins argued that the schema for the Dogmatic Constitution departed from the Church's prior understanding of itself, which had been a defense of "the primacy and the teaching authority of the Pope, with very little Scriptural, Biblical or patristic background, and no real reflection of the scholarly work that has been going on quietly for the last 50 years in this field."102 In its place, Higgins argued that the Church, as it was then defining itself in the Council, promoted an image "that will not suggest anything juridical. It will be the image of the People of God."103 Consequently, Higgins expected Lumen Gentium to portray "that all of the People of God are equal, that the distinctions [between its members] start after the basic fundamental theological principle ... that we are [all] members of the People of God.” With such an understanding, the Church's identity would become "less of pope to bishop, to parish priest, to curate, to layman,

\footnotetext{
101 Ibid., 1.

${ }^{102}$ George G. Higgins, “Monsignor Higgins' Talk to the CFM Chaplains in Chicago" (address presented to the Catholic Family Movement Chaplains, April 9, 1964), ACUA/GGH Papers, Box 326, Folder 6, 9.

${ }^{103}$ Ibid., 9-10.
} 
but, rather, [to that] of all the people having a common function in the Church ... based initially on the equality of all members and their co-responsibility for the life of the Church." ${ }^{104}$ As a result, Higgins argued that the schema for Apostolicam Actuositatem was secondary in importance when compared to Lumen Gentium, for it seemed to Higgins "that the Schema on the Church is the central Schema, and the practical applications which will come out of a stop-gap Schema on the Lay Apostolate, written before we have clarified our notion of the Church, obviously is not going to be as important, in the long run, to the lay apostolate as the basic Schema on the Church." 105

Higgins believed that this departure from a juridical model to the image of the Mystical Body radically changed Catholics' understanding of the social apostolate and their role within it. Such a change returned "to the true scriptural notion of the Church. The Church is not defined... according to the canons of Aristotelian reason or in canonical or legalistic terms. It is defined ... in terms which have their origin in holy scripture and in the writings of the early Church Fathers." Accordingly, this new identity of the Church held that "the Church is not being examined with an empirical eye but with the eyes of Faith, and under the stimulating image of the Mystical Body of Christ, the People of God, and other images familiar to the early Fathers." Consequently, he believed that "important things are being said about the Church for the needs of current man." ${ }^{, 106}$ Prior to Lumen Gentium, those within the Church "tended to think of the apostolate of the laity as a sharing in the apostolate of the hierarchy." ${ }^{107} \mathrm{He}$ argued that the "emphasis has largely been on the working in organizations which have some official connection

\footnotetext{
104 Ibid., 10.

105 Ibid., $9-10$.

${ }^{106}$ George G. Higgins, "Vatican Council II” (lecture presented at Penn State University on April 15, 1964), ACUA/GGH Papers, Box 326, Folder 9, 14.

${ }^{107}$ George G. Higgins, "Monsignor Higgins' Talk to the CFM Chaplains in Chicago" (address presented to the Catholic Family Movement Chaplains, April 9, 1964), ACUA/GGH Papers, Box 326, Folder 6, 12.
} 
with the Church - 'churchy-type' organizations, not in the bad sense of that word, but as opposed to purely profane organizations - whereas, now, we are going to think of the apostolate of the laity, not as sharing of the apostolate of the hierarchy, but as a sharing in the apostolate of the Church."108 Insofar as Catholic Action was concerned then, the Church hierarchy did not have a right "to tell people that they have an obligation to join an organization," but rather that as a member of the Church they had an "obligation ... to be apostles. And that emphasis is one that could make a radical change both in the structures of ... approach to the lay apostolate and in the layman's understanding of his own role." 109

Higgins believed that an apostolic identity for lay Catholics was an essential component for an effective social apostolate, and that this identity extended beyond the boundaries established by Catholic organizations. This was a personal revelation for Higgins, discovered at a time when he gave the invocation at a civil rights dinner. Looking over the crowd, Higgins remembered that

most of the Catholics who were there ... whether they know it or not, are doing a very effective job on behalf of a very good cause, and they are doing it, at least in the general sense of the word, as a part of their apostolate as baptized Christians. They are not fully conscious of it, some of them are not conscious of it at all.

This personal experience brought Higgins to the conclusion that there existed "very few lay leaders in Washington who belong to Catholic organizations who would have qualified for representation at that dinner," which only emphasized the dichotomy between the Catholic community's “old notion of sharing in the apostolate of the hierarchy and the universal obligation of all Christians to share in the apostolate of the Church in one way or another." Accordingly, Higgins argued that this new identity for lay Catholics, an identity of sharing in an apostleship with the entire Church, was an essential one. It was through this identity that lay

\footnotetext{
${ }^{108}$ Ibid., 13.

${ }^{109}$ Ibid.
} 
Catholics could express their faith through "the normal functioning of their daily lives," as opposed to solely through Catholic organizations and the direction of the hierarchy. ${ }^{110}$ No longer could lay Catholics relegate the apostolate of the Church to those of the religious orders. Instead, the social apostolate became a common call to all members of the Church. If anything, it highlighted the need for lay Catholics to realize this new identity, and to share in the apostolic mission to the modern world expressed in Gaudium et Spes. This was evidenced by the fact that even those Catholics who were socially active did not consciously realize that the work they performed was apostolic in nature.

It was this sharing in the apostolate of the Church as a whole, rather than sharing in the apostolate of the hierarchy, that would define a lay person's responsibility in the world in which they lived. Such an apostolate required Catholics to interact, converse, and engage those whose faith differed from their own. It required them to embrace a world that existed outside the confines of the Catholic organizations to which they belonged. Citing Pope John XXIII, Higgins argued that the Pastoral Constitution asked Catholics "to be 'all things to all men for the sake of Christ," and that it asked its members to "learn to be profoundly sympathetic towards everything in... native culture and civilization which does not conflict with the gospel." As a consequence, he asserted that Catholics were not asked to judge their own culture or civilization, but rather "called ... to help save it - to save it from within, not by sterile argumentation or snarling polemics, much less by force of numbers or by political maneuvering or tactics, but by the force of Christian charity and by our unselfish and disinterested involvement in the everyday work of the world." 111

\footnotetext{
${ }^{110}$ Ibid., 14.

${ }^{111}$ George G. Higgins, "Constitution of the Church in the Modern World," ACUA/GGH Papers, Box 328, Folder 4, 8.
} 
This was the vocation of the laity, which the Declaration on the Lay Apostolate - when

considered in the light of both Lumen Gentium and Gaudium et Spes - made clear:

The laity must take on the renewal of the temporal order as their own special obligation. Led by the light of the Gospel and the mind of the Church, and motivated by Christian love, let them act directly and definitively in the temporal sphere. As citizens they must cooperate with other citizens, using their own particular skills and acting on their own responsibility. Everywhere and in all things they must seek the justice characteristic of God's kingdom. The temporal order must be renewed in such a way that, without the slightest detriment to its own proper laws, it can be brought into conformity with the higher principles of Christian life and adapt to the shifting circumstances of time, place, and person. Outstanding among the works of this type of apostolate is that of Christian social action. This sacred synod desires to see it extended now to the whole temporal sphere, including culture. ${ }^{112}$

As a consequence of this declaration, Higgins believed that the "tone of the entire [Pastoral] Constitution... is to enter into a dialogue with the modern world."113 The Church no longer saw itself as the solution to the world's problems, but rather sought to work with all men in its efforts to find those solutions. Lay members of the Church, in order to accomplish this as part of the Church's apostolate, had to engage, and be free to engage, the modern world in this effort. Such an effort required all members of the Church to undertake a new identity, an identity in which the social apostolate was the natural expression of their person as a Catholic and a Christian. Higgins recognized that such a calling was not an easy one, for it required a new understanding of religion and its importance in public life. Such a transition required all members of the Church to abandon their previous understanding of the Church and their place within it, which had served to "isolate them from instead of involving them in the common task of humanity," and which

\footnotetext{
112 Pope Paul VI, "Decree on the Apostolate of the Laity Apostolicam Actuositatem, Solemnly Promulgated by His Holiness, Pope Paul VI on November 18, 1965," The Holy See, http://www.vatican.va/archive/hist_councils/ii_vatican_council/documents/vat-ii_decree_19651118_apostolicamactuositatem_en.html, quoted from a different translation by George G. Higgins, "The Teaching of Vatican II on Social and Economic Life" (lecture), ACUA/GGH Papers, Box 324, Folder 7, 11.

${ }^{113}$ George G. Higgins, "Address on the Constitution on the Church in the Modern World: Social and Economic Life" (address presented to the Conference on the Main Theological Issues of Vatican Council II, University of Notre Dame, Indiana, March 25, 1966), ACUA/GGH Papers, Box 327, Folder 6, 3.
} 
caused "them to lose interest in the culture and civilization of their own times." ${ }^{114}$ When viewed together, Lumen Gentium and Gaudium et Spes had upended this model, and the world waited for those of the Church to implement it. With its decree, Higgins believed that the Church would live up to the ideal of Pope John XXIII, which was a "warmth of open-hearted and disinterested charity, a passionate concern for freedom, truth, and justice, and a profound sympathy for everything in modern culture and civilization which does not conflict with the Gospel."115

To accomplish this change of identity, Higgins believed that lay Catholics had to meet the call that Pope John XXIII had issued with Mater et Magistra; lay Catholics had to integrate their spiritual and temporal lives. The council had asked all Catholics, "priests and layman alike, but laymen in particular because of their direct involvement in secular affairs - to re-examine our whole notion of the spiritual life to make sure that we understand that, from the point of view of the Christian gospel, there can be no opposition between our professional and social duties on the one hand and our religious life on the other." As Gaudium et Spes declared, the "Christian who neglects his temporal duties... neglects his duties towards his neighbor and even God, and jeopardizes his eternal salvation. Christians should rather rejoice that, following the example of Christ Who worked as an artisan, they are free to exercise all their earthly activities by gathering their human, domestic, professional, social and technical enterprises into one vital synthesis with religious values, under whose supreme direction all things are harmonized unto God's glory."116

\footnotetext{
${ }^{114}$ George G. Higgins, "Address for the Annual Convention of the National Catholic Social Action Conference" (address, Washington, D.C., Aug. 27, 1966), ACUA/GGH Papers, Box 327, Folder 6,12.

${ }^{115}$ Ibid.

${ }^{116}$ George G. Higgins, “Address at the Communion Breakfast for the LaGrange Catholic Woman's Club” (address presented to LaGrange Catholic Woman's Club, LaGrange, Illinois, June 7, 1967), ACUA/GGH Papers, Box 328, Folder 2, 10.
} 


\section{Conclusion}

Gaudium et Spes put to rest any questions concerning the role of the lay apostolate in secular institutions, and whether such membership was a valid expression of that apostolate. For Higgins, the decree on the Constitution of the Church in the Modern World refined his vision for the apostolate in the United States, and in the same stroke validated his efforts in the field. Gaudium et Spes made clear that all Catholics were called to engage the modern world, to change it by participating in it. Higgins could now argue with utmost confidence that the "social apostolate of the Church is not just a hobby or avocation for those who happen to be temperamentally so inclined." ${ }^{117}$ Nor was this the only validation for Higgins, as the decree established a unified apostolate for all members of the Church. Reminiscent of his call for the clergy and laity to work together in a common social goal, the decree established an image of the Church where all shared in the Mystical Body of Christ. Accordingly, there was no separate apostolate for the various members of the Church, but rather a common apostolate shared by all. Naturally, different members of this body had different functions to perform in the pursuit of this goal, but all shared in the same vision. All were called to be apostles for Christ, which provided a sound theological basis for the social apostolate, particularly the laity. Furthermore, this basis flowed from the same theological underpinnings that Higgins had promoted prior to the Council. The identity of the Church had evolved from its prior juridical model to one which rested upon the Church as the image of the people of God. This understanding of the Church rested on the perception of the Church as the Mystical Body, the same imagery initially utilized by Virgil

\footnotetext{
${ }^{117}$ George G. Higgins, "The Laity and Social Action,” The Yardstick, December 24, 1956, ACUA/GGH Papers, Box 345, Folder 16.
} 
Michel. In many ways Gaudium et Spes validated both Higgins' and Michel's call for an identity of "official lay apostleship."

This new identity, and the apostolate it promoted, required the Church to engage in dialogue with the modern world. As a necessity, ecumenism was part and parcel to this effort as Catholics engaged those of other faiths in their attempt to solve the social problems of the day. If their combined efforts were to succeed, those of different faiths had to understand the other. Ecumenism and the social apostolate had to meet "at every turn." ${ }^{\prime 18}$ Following the council, Higgins' work with the Secretariat for Catholic-Jewish relations served as a prime example of these efforts. For his part, Gaudium et Spes was not the only decree of the council that occupied his time during those years, but also that of Nostra Aetate. The following chapter details this effort by Higgins and his contemporaries, particularly those of Ed Flannery, as they sought to strengthen the bonds between the American Catholic and Jewish communities.

\footnotetext{
${ }^{118}$ George G. Higgins, "Address at the Annual Convention for the National Catholic Social Action Conference" (address presented at St. Xavier University, Chicago, IL, Aug. 22, 1968), ACUA/GGH Papers, Box 328, Folder 12, 5 .
} 


\title{
Chapter 7
}

\section{The Start of Dialogue: The Creation of the American Secretariat for Catholic-Jewish Relations}

\begin{abstract}
Now that the Fathers have overwhelmingly approved the declaration, Catholics and Jews alike will want to see it in the long perspective of the future. In other words, they will want to bear in mind that when Pope Paul solemnly promulgated the declaration on Oct. 28 - a blessed landmark in the all-too-tragic history of Catholic-Jewish relations - he was, in effect, writing finis, not to a book, but only to the preface of the first of a long series of volumes which will not be completed until the end of time.
\end{abstract}

- Rev. George G. Higgins, The Yardstick, November 1, 1965

$\phi$

Higgins's efforts as a peritus during the Second Vatican Council were not limited to his work on the Pastoral Constitution of the Church in the Modern World and the Decree on the Apostolate of the Laity. He also contributed to another major decree of the Church during this time, that being Nostra Aetate, the Declaration on the Relation of the Church to Non-Christian Religions. To be clear, Higgins did not participate in its commission, or even in the evolution of its schema, yet he played a vital role in its development during the course of the Council. By doing so, his actions set him on a course that led to his participation in the creation of the Secretariat for Catholic-Jewish Relations. It was a course that would change American CatholicJewish relations for the better, as it led to American Church's official recognition of the importance of Israel as a part of Jewish religious identity. In this sense, Higgins honored what he had helped shape in the decree of the Pastoral Constitution - he engaged in dialogue with "all men of good will" in their pursuit for answers to the dilemmas of the modern world. 


\section{The Second Vatican Council and Nostra Aetate}

Upon arriving at the Council, two separate events secured Higgins' participation in the effort for the declaration of Nostra Aetate. First was the circulation of an "anti-Semitic tract... distributed out of nowhere to each of the 2,000-odd Bishops attending the council. Entitled, 'The Plot Against the Church'.... it was the work of a paranoid or group of paranoids who had an almost psychopathic hatred for Jews."1 Because of it, Higgins "realized, as never before, why the Jewish community, even in a pluralistic society as free and open as our own, is still deeply concerned about the threat of anti-Semitism and has yet to be persuaded that this threat was ended once and for all, with the downfall of Hitler and the collapse of Nazism. The fact is that Hitler and his Nazi gauleiters [sic] had nothing on the group of fanatical anti-Semites who put this miserable tract together." ${ }^{2}$ Second, was the introduction of Malachi Martin to Higgins after his arrival in Rome.

Malachi Martin contacted Higgins on behalf of Cardinal Augustin Bea, the President of the Secretariat for Christian Unity, and the man primarily behind the development and implementation of what would become Nostra Aetate. ${ }^{3}$ Higgins's name had been given to Bea by the American Jewish community, and Martin, as Bea's personal assistant, "wanted to know which bishops he could count on to work on Catholic/Jewish relations. ${ }^{.4}$ It was Martin who kept Higgins informed of all that was happening with the Schema on Non-Christian Religions and its statement on the Jews, while Higgins served as the contact person for the American Jewish

\footnotetext{
${ }^{1}$ George G. Higgins, "Address at a Dinner Commemorating the Third Anniversary of the Vatican Council's Declaration on Catholic-Jewish Relations" (address presented at the White Plains Hotel, White Plains, New York, Oct. 28, 1968), ACUA/GGH Papers, Box 288, Folder 5, 1.

${ }^{2}$ Ibid., 2.

${ }^{3}$ Besides being Bea's personal assistant, Malachi Martin was a professor of paleontology at the Pontifical Biblicum Institute in Rome.

${ }^{4}$ George Higgins, interview by George Costello, January 9, 1980, Washington, D.C., ACUA/GGH Papers, Box 435, Folder 2, 34; In the same interview, Higgins describes Martin as a "sort of a leg man... [a] sort of a mystery man who ran errands for Bea."
} 
community. ${ }^{5}$ By Higgins's own admission, he "never actually worked on the Schema ... [and] was never on the commission, but for the next four years ... was in constant touch with the problem, and in constant touch with Jewish representatives there, who were over there representing the various American Jewish groups." ${ }^{, 6}$ Among these Jewish contacts was Joe Lichton of the Anti-Defamation League, and both Zac Scheuster and Marc Tanenbaum of the American Jewish Committee. Besides this, Higgins did his best to influence American bishops in defense of the schema, particularly Archbishop Patrick O'Boyle of Washington, DC, who also served as the Chancellor of the Catholic University of America.

The genesis of Nostra Aetate rested with Pope John XXIII and Cardinal Bea, who in their discussion of the schema wished to change the dialogue and relationship of the Catholic Church with the Jewish community, especially in light of the devastating events of the Holocaust. On November 19, 1963, Bea explained the need for such a declaration. He argued that following the genocide of approximately 6 million Jews at the hands of the Nazis, who had engaged in propaganda of a religious nature, it was essential that the Church educate its members and correct any religious beliefs among them that served to promote anti-Semitism. Primary among these beliefs was the assertion that the Jewish people were guilty of deicide, and that they had been cursed by God. ${ }^{7}$ Unfortunately, this accusation of deicide, and its fruits, served to create a conflict over the appropriateness of the declaration.

\footnotetext{
${ }^{5}$ This schema had originally been the fourth chapter of the schema on ecumenism, which was composed of five chapters. The chapters of this schema were divided on April 16, 1964 into 3 schemas: the schema on ecumenism (the first 3 chapters), the schema on the Jews and non-Christians (fourth chapter), and the schema on religious liberty (fifth chapter).

${ }^{6}$ George Higgins, interview by George Costello, January 9, 1980, Washington, D.C., ACUA/GGH Papers, Box 435, Folder 2, 34 .

${ }^{7}$ Guiseppe Alberigo \& Joseph A. Komonchak, History of Vatican II, Vol. IV: Church as Communion, Third Period and Intercession, September 1964 - September 1965 (Maryknoll \& Leuven: Orbis and Peeters Publishers, 1995), 138.
} 
The initial drafts of Nostra Aetate addressed the issue of deicide by declaring "that 'Christ voluntarily suffered his passion and death because of the sins of all mankind' and recalled that Christ, Mary, and the apostles were born into the Jewish people. It also expressed the Council's desire to increase a mutual knowledge and esteem of Christians and Jews for each other through theological studies and fraternal meetings; at the same time, while declaring its stern censure of the injuries everywhere inflicted on human beings, it deplored and condemned the 'hate-filled persecutions of the Jews, whether in the past or in our own time.' It therefore urged that care be taken in catechetical instruction, preaching, and everyday relationships not to describe the Jews as a rejected people or accuse them of deicide, and to avoid saying or doing anything that might breed hatred and contempt of Jews. The ending was solemn and peremptory in tone: 'For all such words and actions are opposed to the will of Jesus Christ, who embraces Jews and Gentiles in one and the same love." $" 8$

This language did not sit well with all at the Council. Even though the schema also addressed other non-Christians, political observers from Arab nations objected to the declaration, presenting any and "every 'concession' to the Jews... as an act of hostility to the Arabs, if not a first step toward Vatican recognition of the state of Israel." 9 Besides this, many at the council feared that any "conciliar declaration alluding, directly or indirectly, to the responsibility of Catholics or of the Church in the persecution of the Jews ran the risk of ... providing grist for the mill of Pius XII's accusers," who argued his silence had contributed to the Holocaust. ${ }^{10}$ Changes were made to the text to accommodate these concerns, particularly the inclusion of a section acknowledging the Muslim faith, language clarifying the declaration as a religious - not a

\footnotetext{
${ }^{8}$ Ibid., 142.

${ }^{9}$ Ibid., 138.

${ }^{10}$ Ibid., 140.
} 
political - document, and removal of the term "deicide" from the text altogether. This done, the final text retained much of the character and intent of the original draft presented by Bea. While it singled out the "Jewish authorities and those who followed their lead... [as those who] pressed for the death of Christ," the document distinguished that leadership from the whole of the Jewish community, stating that "neither all Jews indiscriminately at that time, nor Jews today, can be charged with the crimes committed during his passion." It also instructed the Church to be mindful of this in their relationship with the Jewish community, stating that "the Jews should not be spoken of as rejected or accursed as if this followed from holy Scripture.... Indeed, the Church reproves every form of persecution against whomsoever it may be directed. Remembering then, her common heritage with the Jews and moved not by any political consideration, but solely by the religious motivation of Christian charity, she deplores all hatreds, persecutions, displays of anti-Semitism leveled at any time or from any source against the Jews."11

The document did not appear to go so far as Higgins hoped, which was to declare that it was "theologically unsound and very unjust for Christians to refer to the Jews as Christ-killers, to blame the crucifixion of Christ on the Jews as a race or a people, and that this grotesque theological misinterpretation of the Scriptures must be rooted out not only of any liturgical documents in which remnants of it may be present, however few, but also must be countered consciously in our catechetical work, in our preaching, and through every other means at the disposal of the Church." ${ }^{, 12}$ It is for this reason that Higgins described Nostra Aetate as an imperfect document, but one that "in spite of its imperfections - which are just as disappointing

\footnotetext{
${ }^{11}$ Austin Flannery, O.P., ed., Vatican Council II: The Conciliar and Postconciliar Documents, Vol. 1 (Northport: Costello Publishing Company, 2004), 741.

${ }^{12}$ George Higgins, "Vatican Council II" (address presented at Penn State University, April 15, 1964), ACUA/GGH Papers, Box 326, Folder 9, 22.
} 
to this writer and to many of the council Fathers as they are to our Jewish friends - it is on the whole, a very good declaration and one which ... holds out great promise for the future."13

Higgins clearly understood Nostra Aetate as a beginning, a start to dialogue with the Jewish community. The responsibility for the start of this dialogue lay with the Church, however, and this is why Higgins pointed out the document was addressed to Christians, and not to Jews. Higgins argued that if the "Jews mistakenly think that the declaration was addressed to them and was meant - insultingly and condescendingly - to 'absolve' them from responsibility for the Crucifixion, they will understandably be very reluctant to enter into dialogue with Christians. And, by the same token, if Christians fail to understand that the declaration was meant to be a sincere examination of the Christian conscience - which has so much to answer for in this area they will be ill-prepared for the kind of dialogue which is strongly recommended by the document."14

Ultimately, the American Secretariat for Catholic/Jewish Relations was the American Catholic Church's concerted attempt to start dialogue with the Jewish community. While Nostra Aetate did not solely focus on Catholic-Jewish relations, Higgins and his contemporaries recognized that "American Catholics... can rightly be expected to assume world leadership in implementing ... [Nostra Aetate's] guidelines [on Catholic/Jewish dialogue] if only because of the fact that roughly half of the Jewish people in the world live as our friends and fellow citizens

\footnotetext{
${ }^{13}$ George Higgins, "A Guide in Brotherhood,” The Yardstick, November 1, 1965, ACUA/GGH Papers, Box 292, Folder 3.

${ }^{14}$ George Higgins, "Toward Fruitful Jewish-Christian Doctrine," The Yardstick, March 14, 1966, ACUA/GGH Papers, Box 292, Folder 3.
} 
within the boundaries of the United States." ${ }^{15}$ When Higgins and his contemporaries returned from the Council, they set out to do exactly that.

\section{The Genesis of Dialogue: Creation of the American Secretariat for Catholic-Jewish Relations}

Following the Council, the American hierarchy took its first steps in Catholic-Jewish dialogue by creating the subcommission on Catholic-Jewish Relations of the United States Bishops' Commission on Ecumenism in 1965. In November of 1966 it issued the "Guidelines for Catholic-Jewish Relations," which had the full support of the American hierarchy. These guidelines would later serve as a framework for the Secretariat, which was created two years later. The guidelines echoed those of Nostra Aetate, and were as follows:

1. The message of the Vatican II statement was clear, and it served to remind Catholics of "the special place Jews hold in the Christian perspective, for "now as before God holds them as most dear for the sake of the patriarchs; he has not withdrawn his gifts or calling.' Jews, therefore, the Fathers caution, are not 'to be presented as rejected or accursed by God, as if this followed from Holy Scripture." Furthermore, the Guidelines remind Catholics that "the Passion of Jesus... cannot be attributed without distinction to all Jews then alive, nor can it be attributed to the Jews of today."

2. "Scholarly studies and education[al] efforts . . to show the common historical, biblical, doctrinal and liturgical heritage shared by Catholics and Jews, as well as their differences. .."

\footnotetext{
${ }^{15}$ George G. Higgins, “'Teach Me, O My God, To Look Upon Humanity As You Yourself Behold It...,” The Yardstick, January 27, 1975, ACUA/GGH Papers, Box 291, Folder 1; In the same article Higgins recognizes that Nostra Aetate addressed those of other non-Christian faiths besides Judaism, and argues that since "our day-to-day contacts with members of these great religious faiths are, for the most part, rather limited and because even our theoretical or text-book knowledge of their respective teachings and traditions is skimpy at best, it will take great effort and imagination on our part to respond effectively to the Council's urgent call for dialogue between ourselves and them, dialogue aimed at promoting mutual understanding and respect." Despite this call for work towards dialogue with those non-Christian faiths, very little appears in the Higgins' collection that demonstrates such work.
} 
3. As the statement requires, the presentation of the Crucifixion story ... in such a way as not to implicate all Jews of Jesus' time or of today in a collective guilt for the crime....

4. In keeping with the [Statement's] strong repudiation of anti-Semitism, a frank and honest treatment . . . in our history books, courses and . . curricula . . . of the history of Christian anti-Semitism.

5. [A study of the life of Jesus] and of the primitive Church in the setting of the ... religious, social and cultural [features] of Jewish [life] in the first century.

6. An explicit rejection ... of the historically inaccurate notion that Judaism of that time, especially ... Pharisaism, was a decadent formalism and hypocrisy [well exemplified by Jesus' enemies]....

7. [An acknowledgment by] Catholic scholars [of] the living and complex reality of Judaism after Christ . . . and the permanent election of [Israel], alluded to by St. Paul (Rom 9:29), and [incorporation of] the results into Catholic teaching.

8. [A full and precise explanation] of the use ... of [the] expression "the Jews" by St. John and other New Testament references [which] appear to place all Jews in a negative light. (These expressions and references should be fully and precisely clarified in accordance with the intent of the ... statement . . that Jews are not to be "presented as rejected or accursed by God as if this followed from Holy Scripture." 16

Following their publication, the bishops selected Bishop Francis P. Liepzig of Baker, Oregon to chair the Committee for Ecumenical and Interreligious Affairs, and charged him with the responsibility of setting up the Secretariat, which would replace the Subcommission. Created in 1967 by the American bishops at their annual meeting, the Secretariat would still "pursue the same goals as the old Subcommission and seek to provide assistance to all dioceses in their implementation of the Guidelines. ${ }^{, 17}$ Higgins served as the bishop's right-hand-man during the

\footnotetext{
${ }^{16}$ Subcommission on Catholic-Jewish Relations, "Guidelines for Catholic-Jewish Relations," Seton Hall University, 1966, ACUA/GGH Papers, Box 293, Folder 7.

${ }^{17}$ Secretartiat for Catholic-Jewish Relations Press Release, Jan. 26, 1968, ACUA/GGH Papers, Box 291, Folder 6.
} 
Secretariat's organization, helping Liepzig "get started with the paperwork, etc., organizing a few meetings, and that sort of thing ... [and since] they had to get a staff man ... [Higgins] pushed hard for Ed Flannery, and then he came on full-time." ${ }^{, 18}$ From that point on, Fr. Edward Flannery served as its Executive Secretary, while Higgins served on the Executive Committee of the organization, as well as its Board of Consultors. Centered at Seton Hall University, South Orange, New Jersey, Bishop Liepzig remained as the Moderator for the Secretariat for another three years. Other members of the Executive Committee and Board of Consultors were as follows: Bishop Aloysius J. Wycislo, the Auxilary Bishop of Chicago; Bishop Mark J. Hurley Auxiliary Bishop of San Francisco; Monsignor John M. Oesterreicher, the Director of the Institute of Judeo-Christian Studies at Seton Hall; Father John B. Sheerin, C.S.P., the editor of The Catholic World; and Father Bernard Law, the Executive Director of the Bishops' Committee for Ecumenical and Interreligious Affairs (and later Cardinal/Archbishop of Boston). In 1970 the Secretariat reorganized, terminating the Board of Consultors and the Executive Committee in favor of a singular Advisory Committee. Bishop Helmsing of Kansas City succeeded Leipzig as the Chairman, while Francis J. Mugavero, Bishop of Brooklyn, took over as the Episcopal Moderator of the Secretariat. Flannery continued his work as its Executive Secretary, and Higgins continued his role as an advisor after accepting his invitation as a member of the newly formed Advisory Committee. ${ }^{19}$

The Secretariat sought to aid all dioceses in their implementation of the guidelines set forth by Nostra Aetate, mainly to increase Catholic-Jewish understanding and dialogue. It promoted lecture tours on Catholic-Jewish relations, but also served as a PR machine,

\footnotetext{
${ }^{18}$ George Higgins, interview by George Costello, January 9, 1980, Washington, D.C., ACUA/GGH Papers, Box 435, Folder 2, 34.

${ }^{19}$ Francis J. Mugavero to George Higgins, March 12, 1970, ACUA/GGH Papers, Box 291, Folder 8.
} 
distributing the Bishops' Guidelines on Catholic-Jewish relations, and their instructions on how to modify Catholic liturgical practices according to the will and intent of the document. ${ }^{20}$ It also provided information that focused on "“'textbook studies, sermons on Catholic-Jewish relations, information on Institutes of Jewish Studies, statements on the current theological thinking of the Church on the Jewish people, the structure of the Jewish community and the like." ${ }^{21}$ Finally, the Secretariat served as the voice of the American Church on public events and incidents of a Jewish nature. The working relationship between Flannery and Higgins would guide the Secretariat throughout its early years, defining it especially in moments of crisis and conflict.

From its start the members of the Secretariat expressed their concern over how effectual such an organization might be. John M. Oesterreicher, another member of the Executive Board, warned Higgins that if the Secretariat "is to be alive to the problems of today and if it is to have its proper impact on the Catholic community as well as the community at large, it must speak out. If it remains silent in the face of various crises one and the same time spreading doom and offering new life, it will be judged a paper organization." 22 Fortunately for them both, plenty of opportunities arose for the organization, and its supporters like Higgins, to speak out.

\section{The First Test of Dialogue: The Israeli Arab War of 1967}

The Israeli Arab War of 1967 provided the first test for the new Secretariat and its attempt at dialogue with the American Jewish community. As the war unfolded, the American hierarchy remained silent about the conflict, refusing to take sides. Unfortunately, this brought

\footnotetext{
${ }^{20}$ Proceedings of the Plenary Meeting of the Secretariat for Catholic-Jewish Relations, Commodore Hotel, New York, NY, November 20 - 21, 1968, ACUA/GGH Papers, Box 291, Folder 7, 1.

21 Ibid., 2.

${ }^{22}$ John M. Oesterricher to George Higgins, Nov. 11, 1968, ACUA/GGH Papers, Box 291, Folder 6.
} 
about a conflict of its own, as members of the Jewish community interpreted their silence in a negative light. Consequently, Higgins believed as a "major crisis in the area of Christian-Jewish relations" was developing. Unfortunately, two of Higgins's friends, Rabbis Balfour Brickner and Arthur Hertzberg, made matters worse by criticizing the hierarchy. ${ }^{23}$ In June of 1967, Brickner, the Director of Commission on Inter-faith Activities of American Reformed Judaism, as well as Hertzberg, a columnist for the National Catholic Reporter, publicly chastised the "Catholic Church in the United States for its failure to speak out more vigorously on behalf of Israel during her recent war with the United Arab Republic and other Arab nations." 24 Such an accusation did not sit well with Higgins..

Higgins was unwilling to accept such claims, and immediately addressed the charges in his Yardstick column of that month. From Higgins's perspective, he believed that both Brickner and Hertzberg argued "from the premise that the Israeli-Arab war was a religious, not to say a 'holy' war, and that consequently the American Catholic 'establishment' (i.e., the American hierarchy) was under some sort of moral obligation to support the Israelis without any reservation and to do so not merely as American citizens, but collectively and officially in the name of Catholicism and on behalf of the entire Catholic community in the U.S." 25 Perhaps even worse, both Brickner and Hertzberg had charged that the "hierarchy's failure to do so... is prima facie evidence that the Church in the U.S. is, at best, a fair-weather friend of Judaism and ... has only been giving lip service to the cause of Catholic-Jewish understanding on matters of common interest and concern in the field of religion and civic action." He accused both men of

\footnotetext{
${ }^{23}$ George Higgins, “Jewish-Christian Dialogue,” The Yardstick, Dec. 4, 1967, ACUA/GGH Papers, Box 370, Folder 2.

${ }^{24}$ George Higgins, “The Israeli-Arab War,” The Yardstick, June 30, 1967, ACUA/GGH Papers, Box 370, Folder 2; Arthur Hertzberg would later serve as the president of the American Jewish Congress from 1972 to 1978, and then as vice-president to the World Jewish Congress from 1975 to 1991 (Joseph Berger, "Rabbi Arthur Hertzberg, Scholar and Blunt Advocate for Civil Rights, Dies at 84," The New York Times, April 19, 2006).

${ }^{25}$ Ibid.
} 
having committed a "form of ecumenical or inter-religious blackmail," and argued that both men had placed an undue requirement on the existing dialogue. This requirement essentially stipulated "that if the Catholic Church in the U.S. wants to enter into a meaningful dialogue with the American Jewish community on religious matters, it must first of all present its credentials in the form of a national statement by the hierarchy in all-out support of the Brickner-Hertzberg thesis that Israel's tragic war against the Arabs was a religious, not to say a 'holy' war."26

This charge, and its corresponding requirement for dialogue, was unacceptable for two reasons. First, Higgins argued that both Brickner and Hertzberg misunderstood the "competence and power of the American hierarchy in the field of public policy, whether domestic or international." He pointed out that the "Bishops, acting as a collective body, can provide a certain measure of moral guidance on such matters, but they cannot force the conscience of their people," especially in matters where the nature of an event, whether it is a religious or political circumstance, was in question. ${ }^{27}$ Second, Higgins noted that neither Brickner nor Hertzberg fully represented the Jewish community, and whether that community had judged the Israel Arab War as a religious matter. He acknowledged their right to declare such a war a religious matter on their own authority, but charged they had "no right to expect ... all of their Jewish fellowcitizens ... to agree with them.” In fact, Higgins charged that many American Jews did not. ${ }^{28}$

Enough of the community did object to Higgins' treatment of Brickner and Hertzberg for Higgins to revisit the issue, however. Noting the "Jewish leaders who have expressed concern about my column of June 30, " Higgins clarified his earlier column. ${ }^{29}$ Higgins apologized to

\footnotetext{
${ }^{26}$ Ibid.

27 Ibid.

28 Ibid.

${ }^{29}$ George Higgins, "Further to the Jewish-Catholic Dialogue," The Yardstick, July 31, 1967, ACUA/GGH Papers, Box 370, Folder 2.
} 
Brickner publicly for the charge of interreligious blackmail, noting that the full text of his Los Angeles speech differed substantially from "the truncated summary in the New York Times." In particular, Higgins acknowledged Brickner's call for more Jewish participation in CatholicJewish dialogue, and was not "laying down any pre-conditions as a kind of quid-pro-quo for his own participation in such dialogues." ${ }^{30}$ Besides this, Higgins clarified his rebuttal, noting that he “did not mean to suggest... that you and Rabbi Hertzberg had called for a 'holy war' against the $\underline{\text { Arabs, }}$, but rather "that your apparent identification of the political Israel of the contemporary world and the religious Israel of the prophets tended to confuse the issue and ... create the impression that the Israeli-Arab war had somehow taken on a religious coloration.” Higgins stood his ground in relation to the hierarchy, however, arguing that the two "were much too critical of the American hierarchy and much too insensitive in the manner in which ... [they] expressed ... [their] criticism in the public prints." Furthermore, he charged that they had done so "without any prior discussion of the matter with your many friends in the Catholic community, who, if ... [they] had consulted with them in advance, might have been able to clarify the situation to a certain extent." And while Higgins withdrew his charge of blackmail, he argued that they "left the impression ... that the American bishops should have said so-and-so in the name of interreligious unity and not merely in the name of international justice." This being the case, Higgins warned Hertzberg and Brickner that if they wanted "church leaders to speak out on the specific issues involved in the Israeli-Arab conflict ... [they] must expect them - at times - to say things that ... [they] might not like to hear., ${ }^{31}$ Higgins then closed the column by professing his belief that this "interreligious crisis" would only serve to strengthen the relationship and dialogue between the two communities of faith, and would help "distinguish

\footnotetext{
${ }^{30}$ Ibid.

${ }^{31}$ Ibid.
} 
more clearly between essential and non-essential differences of opinion between ... [the two] respective communities." 32

Hertzberg, in his own way, seemed to confirm Higgins' assessment of the "crisis" and its impact on Catholic Jewish dialogue. Writing in his column for The National Catholic Reporter, and publicly quoted in a later column of The Yardstick by Higgins, Hertzberg acknowledged that the "overwhelming majority of the very rabbis who pushed their Christian colleagues hardest in May and June have come to a different view of both the usefulness and even the achievements of the dialogue." This different view recognized the importance and the resilience of the dialogue itself, for as Hertzberg recognized, the reality that Catholics and Jews "could continue to talk at all, and that we kept coming back to talk some more, in the midst of a situation that was laden with deep and explosive emotions, was in itself a great new fact." It was a fact that enough "relationship had been built up in recent years between responsible Jews and Christians that we remained in the same rooms even when we were very angry with each other," which was in and of itself a tribute to the dialogue that had been created. ${ }^{33}$ Consequently, through the events and debate surrounding the Israel Arab War, both communities realized the validity of the dialogue itself.

The issue of Israel remained a concern for the Secretariat throughout the 1970s, especially as the organization began to recognize the importance of the Land in Jewish theology. And while the Higgins and the Secretariat did not agree with all of Israel's actions during this time, the organization did acknowledge that Israel was an integral part of the Jewish identity, and so was an intrinsic part of the dialogue between faiths. Ironically, this realization did not develop

\footnotetext{
${ }^{32}$ Ibid.

${ }^{33}$ Arthur Hertzberg, "The Dialogues: A Time for Binding Up Sores," The National Catholic Reporter, Nov. 22, 1967, quoted by George G. Higgins, "Jewish-Christian Dialogue," The Yardstick, December 4, 1967, ACUA/GGH Papers, Box 370, Folder 2.
} 
through dialogue with the Jewish community, but instead arose through conflict within the Catholic community itself. However, in doing so, the Secretariat helped better define the place of Israel in Catholic-Jewish dialogue for years to come.

\section{The Catholic Development and Recognition of a Theology of the Land}

For his own part, Higgins began to nuance his view of the role of the state of Israel in relation to the theology of the Jewish people independently of the conflict. Following the events of that summer, Higgins acknowledged possessing a "meager knowledge of Judaism as a living reality," and declared his hopes better to understand what the state of Israel meant "theologically to the Jewish people." ${ }^{34}$ This is important to note if only because it marks a departure from Higgins's (and the Secretariat's) stance that the state of Israel was reserved as a political issue, and the recognition that if meaningful Catholic-Jewish dialogue was to have a chance, it had to "include a profound study of the theological meaning of Israel from the Jewish point of view."35

Higgins turned to Msgr. John M. Oesterreicher, another member of the Secretariat, for the answer to this particular problem. Citing Oesterreicher's work, Brothers in Hope, in his Yardstick column, Higgins promoted what would serve as the theological basis for the American Secretariat's support of Israel in years to come. Higgins agreed with Oesterreicher that Christians did not hold to the belief that some places were holier than others, and as a consequence, no land offered "a similar role in the religious experience of the Christian as does the land of Israel in the experience of the Jews." Recognizing this fact did not prevent the Christian from appreciating

\footnotetext{
${ }^{34}$ George Higgins, "Christian-Jewish Relations," The Yardstick, Feb. 7, 1972, ACUA/GGH Papers, Box 292, Folder 4.

${ }^{35}$ George Higgins, "The New Serenity in Christian -- Jewish Relations," Interchange, October 31, 1994, ACUA/GGH Papers, Box 290, Folder 7.
} 
the Jewish experience, however. Quoting Oesterreicher again, Higgins agreed with his assessment that while "this lack of experience makes it difficult for the Christian to grasp the Jewish attachment to 'the land,' it certainly does not forbid him to respect this attachment." Consequently, Higgins joined Oesterreicher in his argument that there is "no religious tenant that imposes on him a detached or neutral stance toward the reality that Jews have regained their ancient land and now live under their own flag." ${ }^{, 36}$ Higgins and Oesterreicher were not content with this stance, however, and went beyond this call for respect of Israel. They argued that the "living reality of the State of Israel should ... evoke the respect and admiration of the Christian theologian," and that for the theologian, "Israel's future cannot be a mere political problem." Furthermore, they asserted that while "the exact boundaries of the State ... and many similar questions are the kind of political problems that are fully outside his special competence ... the question of whether the sovereign State should stay on, or be wiped off, the face of the earth" was not. ${ }^{37}$ This view was later complemented by Higgins, who defined the nuances of this development in dialogue through the lens of the Second Vatican Council, when he asserted that the larger theological task of Christians was to renew their "understanding of the Jews as a living people who remain in valid covenant with God." 38 Part of this understanding had to include the promise of the Land, a promise by God recognized by both religions, specifically by the Church who recognized in Nostra Aetate that "according to God's saving design, the beginnings of her faith and election are found already among the Patriarchs, Moses, and the prophets.",39

\footnotetext{
${ }^{36}$ George Higgins, "Christian-Jewish Relations," The Yardstick, Feb. 7, 1972, ACUA/GGH Papers, Box 292, Folder 4. 
Consequently, this served as the genesis of the American Secretariat's consistent support of Israel, at least in regard to its right to exist as a sovereign nation. From the viewpoint of Higgins and his contemporaries, any type of peace accord had to include recognition of Israel as a nation with its own boundaries and borders. However, this was as far as the Secretariat was willing to address the issue, for definition of those boundaries and the inner workings of the Israeli state were seen as purely political in nature. Furthermore, such a stance did not challenge Pope Pius XII's suggestion of giving "Jerusalem and its outskirts ... an international character," which had been expressed in the encyclical In Multiplicibus Curis in $1948 .{ }^{40}$ Not everyone agreed with this assessment however, particularly Father Joseph L. Ryan, S.J., and separately, Bishop Joseph T. Ryan of Anchorage, Alaska. ${ }^{41}$

\section{The Conflict over the Land: The Catholic Monologue Concerning Israel and Its Support by the Body of Bishops}

\section{Part One: The Objections of Fr. Joseph L. Ryan, S.J.}

Father Joseph Ryan began his novitiate in 1938 as a member of the New England Province, receiving his bachelor's degree from Weston College, and later his graduate degree from Boston College. ${ }^{42}$ Following his graduate studies, he served as the Dean of Al-Hikama University in Baghdad, Iraq from 1965 to 1966, and then as its Academic Vice-President

\footnotetext{
${ }^{40}$ The Vatican, "In Multiplicibus Curis: Encyclical of Pope Pius XII on Prayers and Peace in Palestine," http://www.vatican.va/holy_father/pius_xii/encyclicals/documents/hf_p-xii_enc_24101948_in-multiplicibuscuris_en.html (accessed on 10.30.2013).

${ }^{41}$ To be clear, these are two separate men, with the same name, who shared eerily similar views on the topic of Israel and its place in the existing dialogue between Catholics and Jews in the United States. Documentary evidence supports an alliance between these two men, but is limited at the current time.

${ }^{42}$ Holy Cross Magazine, "In Memoriam," http://www.holycross.edu/departments/publicaffairs/hcm/hcmam98/in_memoriam/1951.html (accessed on $\underline{10.15 .2013) .}$
} 
from1966 to 1968. Following his tenure at Al-Hikama University, he came back to the United States as a Visiting Fellow of the Cambridge Center for Social Studies in Cambridge, Massachusetts, in which capacity he served for two years, 1969 to 1971 . It was there he set up shop at 42 Kirkland Street, and sought to insert himself, and what he considered to be the voice of the Arab community, in the ongoing dialogue between Catholics and the Jewish community. ${ }^{43}$

Joseph L. Ryan's presented himself to the Secretariat in June of 1969 by letter to Edward Flannery, and later to Higgins in July of the same year in a joint letter to both men. By the time Higgins responded in August, it is clear that an ongoing debate was developing between Flannery and Ryan over Israel's significance in the Catholic-Jewish dialogue. Perhaps due in part to his Yardstick columns confronting Brickner and Hertzberg during those same summer months, Ryan sought Higgins's help in the debate between the two. Writing that he was not "technically qualified to referee ... [the] continuing debate with Father Flannery," Higgins offered to serve as an observer in any future meeting between them, but warned Ryan that as a "student of the Israeli-Arab problem," he found himself "agreeing substantially with Flannery's point of view." He informed Ryan that after a "considerable amount of experience over the course of many years in dealing with all of the principle lay and rabbinical Jewish groups in the United States," he had arrived at the same conclusion as Flannery, which was "that the vast majority of Jews in this country 'take the attitude of Christians to the State of Israel as a measure of Christians' real desire for dialogue with Jews.",44

\footnotetext{
${ }^{43}$ Joseph L. Ryan, "Refugees within Israel: The Case of the Villagers of Kafr Bir'im and Iqrit," Journal of Palestinian Studies 2, No. 4 (Summer, 1973); it should be noted that Father Ryan continued his effort in Beirut, Lebanon as well, where he served as a member of the Center for the Study of Modern Arab World at St. Joseph's University following his time at Cambridge.

${ }^{44}$ George Higgins to Joseph L. Ryan, August 5, 1969, ACUA/GGH Papers, Box 54, Folder 14.
} 
This did not stop Ryan's attempts to pull Higgins into the confrontation, however, as he followed up his earlier attempt with another letter which contained an article by Dr. John H. Davis, titled "Evasive Peace in the Middle East." Perhaps hoping to sway Higgins to his perspective, Ryan asserted that Davis's article presented an accurate view of Israel and its policies, as well as its place within Catholic-Jewish dialogue. The article argued that Israel had no valid claim to its occupied lands, and that its continued existence rested upon continued injustices perpetrated by a Zionist regime against the indigent Arab population - a population forced to relocate because of the continued Israeli seizure of Arab lands. Davis in particular argued that Zionism was a "form of aggressive nationalism and as such must not be equated with Judaism," but should be associated with the state of Israel, since it was the force that now dominated the country. ${ }^{45}$ The threat of Zionism did not rest in Israel alone, however, for Davis charged that America had "permitted herself to become tied to a special interest policy that doesn't work ... [which] is because policy-makers have permitted themselves to become subservient to pressures - Zionist pressures."46

These were points in which Ryan agreed whole-heartedly, for as he saw it, some "Christians in this country," most likely meaning Flannery and his contemporaries at the American Secretariat, upheld "an uncritical doctrinaire pro-Zionist political position," and seemed "to do so in the name of developing good relations with American Jews." These views were particularly dangerous for the laity of the Church in America, since they created an impression "that a monolithic point of view is held by all Jews and also that a Christian has no

\footnotetext{
${ }^{45}$ John H. Davis, "Evasive Peace in the Middle East" (address at Old South Church, Boston, Oct. 26, 1969), ACUA/GGH Papers, Box 292, Folder 7, 1; Joseph Ryan included this address by Davis in his letter to George Higgins, dated October 30, 1969 (Joseph L. Ryan to George Higgins, October 30, 1969, ACUA/GGH Papers, Box 292, Folder 7).

${ }^{46}$ Ibid., 5.
} 
choice to accept this monolithic point of view in order to be ecumenical." ${ }^{, 47}$ Ryan did not agree that such a "monolithic" point of view was held by all Jews, even if this was the perception of American Christians, and used yet another article to support his case. In his next letter to Higgins, Ryan enclosed Edmund R. Hanauer's article from MIDEAST, titled “The U.S. and Peace in the Middle East: A New Approach." ${ }^{48}$

Hanauer's article described many of the same conditions stated by Davis, yet took a different approach by noting the lack of any group whose sole purpose was to promote peace in the Middle East. Hanauer believed America could serve in such a manner, which he believed was instrumental in the effort to achieve a lasting peace. In an attempt to convince his American readership to encourage such action, he promoted dual settlements to secure the integrity of Palestine's two nations - one Jewish and one Arab. However, Hanauer's presentation of these two nations refuted the viewpoint of Moshe Dayan, the Defense Minister of Israel, who had remarked "that Israel should be as Jewish as France is French." 49 Such an Israel was one that was unacceptable to the Arab nations of the world, for it was "discriminating against its non-Jewish minority, aggressive towards its neighbors, unfeeling towards Palestine's refugees and exclusivist in its ideology." ${ }^{, 50}$ Such a peace, and such an Israel, was only possible through the influence of the United States upon the state of Israel and its Arab neighbors. Calling for a change of ideology surrounding the conflict, Hanauer concluded his article by advocating first an

\footnotetext{
${ }^{47}$ Joseph Ryan to George Higgins, summer of 1969, ACUA/GGH Papers, Box 292, Folder 7; This letter does not have a date, but since the correspondence contains Edmund R. Hanauer's article, "The U.S. and Peace in the Middle East: A New Approach," which appeared in MIDEAST: A Middle East - North African Review in its July/August 1969 issue, it is fair to assume the correspondence soon followed.

${ }^{48}$ Edmund R. Hanauer, "The U.S. and Peace in the Middle East: A New Approach," MIDEAST: A Middle EastNorth African Review 9 (July/August 1969): 3 - 10 (Joseph L. Ryan to George Higgins, October 30, 1969, ACUA/GGH Papers, Box 292, Folder 7); According to his obituaries, Hanauer received his doctorate in political science from American University, and taught evening classes in his field for the University of Maryland (Gloria Negri, "Edmund R. Hanauer, 68, Crusader for Mideast Peace," The Boston Globe, August 23, 2006).

${ }^{49}$ Ibid., 5.

${ }^{50}$ Ibid., 4.
} 
effort "to convince Arab-Americans, Jewish-Americans, and Arab and Israeli students that neither side has made sufficient efforts to achieve peace." Following this request, he also asked the American Jewish community to reassess its support of Israel, which "rather than exerting a moderating influence on Israel, tends to encourage Israel's 'hawks,' thus undercutting the position of Arab moderates." From his viewpoint, both of these actions would serve to promote dialogue between the two factions, which would promote peace. ${ }^{51}$

Ryan's main assertion, or rather question, concerning Hanauer's work was why a Christian could not "hold such a view without being accused, directly or by insinuation, of being anti-Semitic," if an American Jew, like Hanauer, could. From Ryan's perspective, such a question was far more important than whether he or Higgins agreed "with the point of view defended in ... [Hanauer's] article," since "it seemed ... that a person who raises this question does a service, not only to the improvement of relations between Muslims and Christians, but also ... to the improvement of relations between Jews and Christians." ${ }^{, 52}$ As far as the record shows, Higgins never answered Ryan's query. However, it is apparent that this was never Ryan's purpose. Instead, he sought to challenge Higgins's assertion that the majority of Jews interpreted the Christian's stance on Israel as a measure for their desire for dialogue, and by doing so, change his mind on the matter.

By November of 1969 Ryan had held a meeting with Flannery, Higgins, and Oesterreicher, arranged by Monsignor Bernard Law, the executive director of the National Conference of Catholic Bishops' Committee for Ecumenical and Inter-religious Affairs. Writing to Law four days later, Ryan made clear that little had been resolved, and that he had moved on

\footnotetext{
${ }^{51}$ Ibid., 9.

${ }^{52}$ Joseph Ryan to George Higgins, summer of 1969, ACUA/GGH Papers, Box 292, Folder 7.
} 
from his attempts to persuade Higgins to his side of the debate. In his letter to Law, Ryan commented on a news piece published by the Boston Pilot, which had detailed the creation of a joint study by Catholics and Protestants "to investigate the theological dimensions of Israel as a people, as a land, and as a political entity." In his assessment of the article, he lamented the absence of any perspective pertaining to the "attitudes and the conditions of Palestinian Arabs, both Muslims and Christians" as part of the study, and argued that if "the views of pro-Zionist Jews are invited, so also should the views of Arabs, both Muslims and Oriental Christians." Fearing a lack of such information, Ryan then offered areas of investigation that Law and the joint study might pursue. First, he suggested that the study investigate the indigent population of non-Jews that existed prior to the Arab-Israeli War be considered in the discussion of "Israel as a people," as well as the Arabs who were incorporated in the lands seized by Israel during the course of that war. Second, he proposed that the U.N.'s objection to the annexation of East Jerusalem be included in the study, and that Muslim religious considerations of Jerusalem also be taken into account. Finally, Ryan insisted that Oriental Christians also constituted a valid part of the discussion of Israel as a people, given their presence in the Holy Land and their own ties to the city of Jerusalem. ${ }^{53}$

Unfortunately, there is no record of Law's response to Father Ryan following his letter of November 10, 1969, but it appears that Father Joseph Ryan did at least find one supporter of his cause within the American Church. Unfortunately for Higgins and Ed Flannery, this individual was a member of the hierarchy, the Archbishop of Anchorage, Alaska, John Joseph T. Ryan.

\footnotetext{
${ }^{53}$ Joseph L. Ryan to Bernard Law, November 10, 1969, ACUA/GGH Papers, Box 291, Folder 7.
} 


\section{Part Two: The Objections of Archbishop Joseph T. Ryan and His Conflict with Fr. Edward Flannery}

Joseph L. Ryan might have stayed on the outskirts of the Catholic-Jewish conversation over Israel if not for the intervention of John Joseph T. Ryan, the archbishop of Anchorage, Alaska, in response to a circulated paper by Edward Flannery, the Executive Secretary of the Secretariat. In October of 1971 Flannery distributed a paper titled "The Controversy over Jerusalem: Elements of a Solution" to the body of bishops, in which Flannery argued that the urbanization of Jerusalem by the state of Israel must be addressed by the Secretariat. In his treatment of the issue, Flannery asserted that such an address was necessary because of the existence of a "pressure campaign ... [which was attempting to influence] world opinion and the United Nations toward a condemnation of Israel." Unfortunately, this campaign had a "religious character, taking the form of letters, protests, or visits of the clergy to the Holy See and also to the hierarchy of the United States.” As a consequence, Flannery feared that this development had "been highly disturbing to Jews and could not but have definite influence on the course of Christian-Jewish dialogue." 54

There should be little doubt that Father Joseph L. Ryan was counted among those clergy who sought to sway the Holy See and the hierarchy of the United States towards a condemnation of Israel. Seeking to counteract the arguments of Ryan and his compatriots, which Flannery characterized as "factually incomplete and unfair" and at times "calumnious," Flannery had

\footnotetext{
${ }^{54}$ Edward Flannery, "The Controversy over Jerusalem: Elements of a Solution," October, 1971, ACUA/GGH Papers, Box 292, Folder 6, 1.
} 
written his paper to "elucidate further the question of Jerusalem and to add a corrective to the numerous one-sided views that have thus far appeared."

In particular, Flannery addressed the urbanization of Israel occurring at the time, specifically the "'belt of buildings on the hills around the Holy City at the expense of Moslems and Christians," that had been described by an editorial of L'Osservatore Romano in March of that year. After discussing the history of the attempts to internationalize Jerusalem, Flannery questioned whether internationalization of the city that had been proposed by Pius XII in In Multiplicibus Curis was the best solution for the "protection, free access and sacred character of the Holy places of the city," especially in light of Israeli performance in that regard. ${ }^{56}$ This performance, at least from Flannery's vantage point, was that for "the first time since 1948 free concourse in the entire city and free access for all to the Holy Places has been established, and violence has given way to peace." And for those who sought to distort this record, Flannery argued that they failed "to render the picture as a whole and to acknowledge the general improvement of the situation" in Jerusalem. ${ }^{57}$

Furthermore, Flannery asserted that "universality of the city as a whole is largely a thing of the past. Otherwise put, its particularity has increased, and that particularity is largely Jewish." This development was only a continuation of the historical trend, as he argued that "Jews have been the majority group in Jerusalem for well over a hundred years," and that in 1971 the Jews were "three times more numerous than the non-Jewish population." As a result, it was "no longer

\footnotetext{
${ }^{55}$ Ibid.

${ }^{56}$ Ibid, 7.

${ }^{57}$ Ibid, 9.
} 
possible to talk of Jerusalem and the Holy Places univocally," since its "universality" was now more "a historical than an actual fact."

As to whether the Israelis were actively trying to "suffocate" the Muslim and Christian populations in Jerusalem through the renewal of city's urban landscape, Flannery first questioned whether one could "Judaize" a city that was already, and had been for some time, Jewish. He pointed out that Jews had been the largest group of people in Jerusalem since 1844, and had become the majority of the population in 1896. Furthermore, he asserted that as a result of its ongoing development as a Jewish cultural center, urbanization of Jerusalem was a necessary action by the Israeli government. In that sense, to propose the actions of that government "as an effort to displace Christians and Moslems and Judaize the city," did not "respect all the facts of the situation or the declared intent of the government." ${ }^{59}$ Furthermore, such work was a necessity and a benefit to the city, as their urbanization efforts cleared out the slums and allowed for the construction of new neighborhoods in their place.

As for the displacement of both Christians and Moslems from Jerusalem, Flannery justified their departure by pointing out that those groups had been offered compensation and relocation within the city limits, so that it would not "disturb the ethnic proportions of the city as a whole." ${ }^{, 60}$ For those who decided to leave Jerusalem, it was a decision made freely. In the case of Christians within the city, he argued that their decision to leave "must be seen as a tendency of

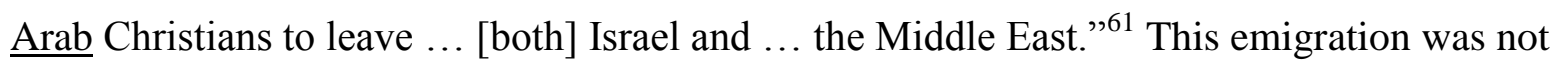
limited to Israel, but was a general trend for the Middle East as a whole, especially in Egypt and Lebanon.

\footnotetext{
${ }^{58}$ Ibid., 10.

${ }^{59}$ Ibid., 18.

${ }^{60}$ Ibid., 19.

${ }^{61}$ Ibid., 20.
} 
Consequently, Flannery recommended a plan similar to that of the Holy See's request for the international sharing of Jerusalem, but in such a way where Israel retained its sovereignty. In this manner, the plan called for Israeli control of Jerusalem and its the holy sites, but would create "a formalized, international agreement respecting the freedom, security and administration of the Holy Places ... [and] which could be extended to include the rights of minorities in the city." Flannery believed that such an arrangement "could take many forms," including as an example, the suggestion that Israel could "bind itself in the form of a treaty or formal declaration concerning its policies regarding the Holy Places and minorities." Regardless of the form it took, Flannery believed that ultimately the plan had to be developed by "the parties most immediately concerned, that is, Israel and the religious bodies whose Holy Places are situated in Israel." 62

None of this sat well with Archbishop Joseph T. Ryan, who labeled the paper a "quasiofficial" document that "grossly distorts the situation" of Israel. Consequently, he felt compelled, as the "former Field Director for the Pontifical Mission for Palestine (1958 - 1960) and as President of the Pontifical Mission in Palestine and Executive Secretary of the Catholic Near East Welfare Association $(1960-1966) \ldots$ to intervene. ${ }^{, 63}$ He did so by writing his own response to Flannery's paper, titling it as "Some Thoughts on Jerusalem," which he then circulated to the body of bishops in an effort to counteract Flannery's influence.

Ryan argued that Christian indifference to the plight of Palestinians and Israeli urbanization policies amounted to "no less than the possible extinction of an effective $\underline{\text { Christian }}$ presence $\underline{\text { in }}$ the $\underline{\text { Holy }} \underline{\text { Land }}$, , and that it was the responsibility of the American hierarchy to use

\footnotetext{
${ }^{62}$ Ibid, 15.

${ }^{63}$ Joseph T. Ryan, "Some Thoughts on Jerusalem," September/October, 1972, ACUA/GGH Papers, Box 292, Folder 6; the date for this paper cannot be accurately determined, as it was not included in the actual document.
} 
their influence to correct this injustice. ${ }^{64}$ From Ryan's viewpoint, Israel was “quietly but inexorably exerting pressure on Arabs to quit Jerusalem and the occupied West Bank." The problem with such a move, at least from Ryan's vantage, was that among those Arabs were some “180,000 Catholic and Protestant Christians.” Consequently, when those Christians left Jerusalem, "the Bishops and Priests of the Catholic and Orthodox Churches" would be left only with "historic - but empty - museums." "65 The Christian presence in Jerusalem would no longer exist.

In order to sway the remainder of the American bishops to support his view, Ryan asserted that Israel's control of Jerusalem was in opposition to the position that the American government and the international community held. He argued that the Holy City had never been included in the U.N. creation of Israel, and that the U.N. had always intended that Jerusalem would remain under international sovereignty. In support of this fact, he pointed out that Israel's seizure of West Jerusalem in 1948, and the remainder of the city in 1967, had been condemned by the United Nations. Nor were these the only international condemnations and admonitions of Israel on the issue of control of Jerusalem, evidenced by Resolution 298, which had been passed on September 26, 1971. As Ryan made sure to point out, this resolution "called on Israel to take no further steps in the occupied sector of Jerusalem to change the status of the city or prejudice the rights of the inhabitants or the international community." ${ }^{66}$ And while these examples spoke of the international view of Israel in relation to Jerusalem, the position of the United States was similar to that of U.N. This was evidenced by the stance of Secretary of State, William P. Rogers, who had made it clear in 1969 that the State Department did not agree with the seizure

\footnotetext{
${ }^{64}$ Ibid., 2.

${ }^{65}$ Ibid., 9.

${ }^{66}$ Ibid., $10-11$.
} 
of Jerusalem during the 1967 war, and that the U.S. would not "accept unilateral actions by any party to decide the final status of the city." Finally, Ryan asserted that Israel's seizure of Jerusalem and other lands in the war of 1967 violated the Geneva Convention, which prohibited "occupying powers from transferring parts of its population into occupied territories." Consequently, Ryan refuted Flannery's effort to convince the bishops that Israel's control of Jerusalem constituted a viable plan for the Holy City.

As for the claims made by Flannery, Ryan set out to disprove them as well. Citing the work of Father Joseph L. Ryan, as well as his meetings with Archbishop Pio Laghi, the Apostolic Delegate to Palestine, Archbishop Ryan asserted that Flannery's paper "simply cannot be taken seriously as a basis for any discussion or action by this body." ${ }^{68}$ This assessment was due in part to Ryan's assertion that the apostolic delegate wholeheartedly disagreed with Flannery's paper, so much so that he rejected "most of the facts and all of the conclusions" asserted therein. In particular, he disagreed with Flannery's historical assessment of Jerusalem's population, arguing that the Jewish claim of a majority in Jerusalem over the past one hundred years depended on its choice of boundaries. Citing the 1931 census conducted by the British, which placed the number of Jews at 55,000 out of a total of 133,000 people, Ryan argued that the Jews did not then constitute a majority. This assertion directly contradicted that of Flannery, who had argued whether it was possible to "Judaize" a city that already was, and historically had been, Jewish.

Ryan closed his presentation by reminding the bishops that Rome called for the international control of Jerusalem, and was quite clear on this issue, despite the occasional

\footnotetext{
${ }^{67}$ Ibid., 11.

${ }^{68}$ Ibid., 16.
} 
"circumspection of language" it employed. ${ }^{69}$ In doing so, he reminded his fellow bishops that the Church should be alarmed by the exodus of Arab Christians from Jerusalem, which served as a source of worry for the Church and all Christians - especially in light of the Vatican's call for Jerusalem to have an internationally religious character. It was for these reasons that Archbishop Ryan asked that the American bishops to speak out on the injustices he detailed. In his words, it was the American hierarchy who could let the "world know that Christianity and Islam are in Jerusalem by right, not by sufferance," and that "Christianity does not -- cannot -- accept the ethnic domination of, or the political sovereignty of, one religion over others., ${ }^{, 70}$

Fortunately for Flannery, both he and George Higgins visited Jerusalem in January of 1972 in order to form a rebuttal to Archbishop Ryan's paper. It is interesting to note that they must have known Ryan's intentions to confront Flannery's paper in advance, as they interviewed individuals mentioned in Ryan's treatment of Jerusalem, specifically in response to Ryan's claims. Furthermore, they submitted their addendum to Flannery's original paper in April of 1972, only one month following Ryan's publication of "Some Thoughts on Jerusalem." Titled "A Second Report on Jerusalem," Flannery charged that he found "no need to repudiate or substantially change the major conclusions" of his original paper. ${ }^{71}$ Instead, his rebuttal focused on repudiating the charges leveled by Archbishop Ryan by providing "informative material to help to clarify a highly complex and controversial subject upon which requests for action were being made." Thus, Flannery intended to "add an omitted dimension in the usual discussion of

\footnotetext{
${ }^{69}$ Ibid., 17.

${ }^{70}$ Ibid., 20.

${ }^{71}$ Edward H. Flannery, “A Second Report on Jerusalem,” April, 1972, ACUA/GGH Papers, Box 292, Folder 6, preface.
} 
the problem of Jerusalem and to answer some charges against Israel which ... [he considered] false or unfair.",72

It is from this position that Flannery addressed Ryan's contacts in the city of Jerusalem, specifically that of the apostolic delegate, Archbishop Laghi, and Father Joseph L. Ryan. Noting that no one could "place question on Archbishop Laghi's competence," Flannery instead questioned “Archbishop Ryan's use of him.” Flannery discovered that Laghi’s position on Jerusalem was quite unlike Ryan's portrayal to the body of bishops. ${ }^{73}$ Noting Ryan's support of an international management of Jerusalem, and his use of Laghi and Pope Paul VI in favor of that position, Flannery argued that neither Laghi nor Pope Paul VI intended that Jerusalem be “territorially internationalized, but merely functionally. In fact, Archbishop Laghi stated explicitly that it is not the business of the Church to seek any political solution to the problem of Jerusalem ... [which included] the question of territorial internationalization." ${ }^{, 74}$ As for the authority of Joseph L. Ryan, Flannery portrayed Fr. Ryan as an "expellee from the Jesuit College in Baghdad, Iraq," and an "indiscriminate anthologist of anti-Israeli materials," and as such was not one of the "most trustworthy witnesses on the subject of Israel.",75

Flannery then turned to Archbishop Ryan's main argument, that the Israeli government was actively pursuing a policy of "Judaizing" the city, and forcing a mass exodus of Christians. Expressing his regret that he "must contradict Archbishop Ryan quite flatly," Flannery asserted that Christians were "not leaving Jerusalem at any great rate, if ... at all." Instead, he argued that

\footnotetext{
${ }^{72}$ Ibid., 3.

${ }^{73}$ It is important to recognize that Higgins served as the witness to this exchange.

${ }^{74}$ Ibid., 4; Flannery later attributes Ryan's mistake to a mistranslation of Pope Paul VI's statement on Israel on June 25, 1971. Noting that Paul VI had called for a special "statute" for Jerusalem, and not a special "status" as Ryan had asserted, this explained why the management of Jerusalem was a matter of functionality, not territory (Ibid., 10).

${ }^{75}$ Ibid., $3,4$.
} 
recent "figures show a stabilized population." ${ }^{, 76}$ Furthermore, instead of "exerting pressures on Arabs to leave," the Israelis were doing all they could to retain its Arab citizens through civic reconstruction, and educational efforts. For those who did leave the city, Flannery presented a case which suggested economic conditions as the main culprit for any Christian emigration from Jerusalem, particularly the recession of 1966 which "caused many Arabs to lose employment," and created the conditions whereby "young and educated Arab Christians ... look abroad for opportunities not available at home." 77 Furthermore, the Christian missionary schools in Israel that educated the majority of Christian populace had become the "launching pads for young Arabs to European countries, such as France and England," and thus had promoted emigration. Consequently, Flannery concluded that "the exodus of Christians from Jerusalem or Israel," was not due to the Israel's influence or policy, but rather "inherent in the economic, social, and cultural texture of Israel and the Middle East itself."78 As for the "Judaization" of the city, Flannery acknowledged that "Jews want to be in all parts of Jerusalem," but that this was natural for them as Jews, and that while Christians understood "this as a desire to 'dominate' the city," what really existed was a "contest of fears." $" 79$ These fears were the responsibility of the Christian to dispel, and by doing so provide peace and reconciliation to the city. ${ }^{80}$

\footnotetext{
${ }^{76}$ Ibid., 5.

${ }^{77}$ Ibid, 7.

${ }^{78}$ Ibid., 7.

${ }^{79}$ Ibid., 7.

${ }^{80}$ Flannery also takes Ryan to task over his presentation of the legality of Israel seizure of East Jerusalem, and the stance of the United Nations on the issue. Noting that the 1948 plan for internationalizing Jerusalem had never been implemented in any way, and that the U.N. had abandoned the plan, Flannery goes on to question Israel's own rights as a sovereign nation in relation to the international community. In particular, Flannery asserts that the seizure of those lands is justified since such an action took place in a defensive war, only after Jordan initiated the conflict.
} 


\section{Continued Conflict: Higgins Enters the Fray}

As one may suspect, the conflict between the two Ryans and Fr. Flannery did not end with his rebuttal of Archbishop Ryan. Instead, it provided the grounds for further discussion, and forced a resolution on the issue of Israel and its place within American Catholic-Jewish dialogue. And while it may appear that Higgins took a backseat during the conflict, this was far from the case. After all, Higgins had accompanied Flannery to Israel in the months prior to his rebuttal of Archbishop Ryan's critique, and had served as a witness to the meeting between Flannery and Archbishop Laghi. Besides this contribution, Higgins also participated in the "Task Force on the Jerusalem Question" which followed the initial exchange between Flannery and Archbishop Ryan.

The taskforce first met on July 14, 1972 in response to Flannery's and Ryan's argument over the place of Israel in Catholic-Jewish dialogue, as well as in response to a request from the "bishops of the Holy Land for a position statement on the Jerusalem question." 81 In studying the question of Jerusalem, the task force acknowledged that the position of the Holy See was not clear, and that there were potentially two different positions on the issue in Rome, as evidenced by both Flannery's and Archbishop Ryan's presentations. The fact that Rome's position was unclear did not mean the matter should be dropped, however, for there were "sufficient indications of the Holy Father's concern that there be free access to the Holy Places guaranteed by some sort of agreement going beyond the control of the Israeli government. $" 82$ Consequently, the task force authorized continued study of the question of Jerusalem and its place within Israel

\footnotetext{
${ }^{81}$ Task Force on the Jerusalem Question, “Task Force on the Jerusalem Question Summary Minutes,” July 14, 1972, ACUA/GGH Papers, Box 292, Folder 7, 1.

${ }^{82}$ Ibid., 2.
} 
and the larger international community. The debate within the American Catholic Church would continue.

Higgins, for his part, sought to remove Father Joseph L. Ryan from the discussion of Israel among the body of bishops in the United States, and expose him as an inexperienced outsider when it came to Catholic-Jewish dialogue. Up to this point, the debate concerning Israel, its treatment of Jerusalem, and its place in Catholic-Jewish dialogue had by and large remained outside the public sphere, intended as a private debate among the body of bishops. However, Fr. Joseph Ryan, who stood outside the body of bishops, had been rather public in his position on Israel and the management of Jerusalem, and did not afford the same respect that Archbishop Ryan enjoyed as a member of the hierarchy. Consequently, on Dec. 11, 1972 Higgins took Father Ryan to task over a lecture he had given on behalf of the Middle East Affairs Council, where Ryan had "charged that ecumenical relations between Christians and Jews in this country have suffered from Jewish insistence on support for Israel as a proof that Christians are not antiSemitic." $^{, 83}$

According to Higgins, Ryan had asserted that the support of Israel by Americans was misguided, since it was based on "the myth that there was a threat of annihilation of the Jewish people" during the Six-Day War of 1967." 84 In response, Higgins accused Ryan of a "complete falsification of the historical record" on the subject of the war and the threat to Israel's survival, which he asserted Father Ryan had been "promoting... persistently for some time." 85 Yet, this was not the most dangerous of Ryan's efforts to challenge the Catholic-Jewish dialogue that had developed over the past seven years. To make matters worse, Ryan had also been attempting to

\footnotetext{
${ }^{83}$ George Higgins, "Catholic-Jewish Relations in the United States," The Yardstick, December 11, 1972, ACUA/GGH Papers, Box 292, Folder 4.

${ }^{84}$ Ibid., 1.

${ }^{85}$ Ibid., 1, 2.
} 
undermine the work of Father Flannery both within the body of bishops, to whom he had sent letters "trying to discredit Flannery's work," and among they American Catholic laity, by painting Flannery in opposition to Rome. In Higgins' words, Ryan had hoped 'to play the Vatican off against American Catholics. ${ }^{, 86}$ Consequently, Ryan's efforts were a blatant attempt to hijack Catholic-Jewish dialogue to serve his own political views concerning Palestine, Israel, and the Holy Land.

This was readily apparent to those involved and working towards the Catholic-Jewish dialogue, but not so apparent to those removed from it - as would be the case with the American public at large. Nothing demonstrated this more than Ryan's attempts to discredit Father Flannery, which Higgins sought to correct as Flannery's "pro-tem predecessor". Consequently, Higgins informed his readership that Flannery was in "frequent and regular contact with the Vatican's Catholic-Jewish Secretariat," and his "position on the subject of Catholic-Jewish relations ... [was] identical to that of [Corneliius] Rijk," who served as Director of the Vatican's Secretariat for Catholic-Jewish Relations. ${ }^{87}$ More to the point, Higgins made clear that Flannery was a "close personal friend of Father Rijk ... [and] his most intimate collaborator in the United States. ${ }^{, 88}$ Consequently, there could be very little doubt of Flannery's orthodoxy, and given Ryan's statements concerning Flannery, it seemed clear - at least to those involved in the dialogue - that he must have had some ulterior motive to his actions other than promoting the ongoing dialogue between Catholics and Jews.

From Higgins's perspective, Father Ryan's efforts were "a great disservice to the cause of Catholic-Jewish relations in this country," if not only for the misinformation that Ryan presented

\footnotetext{
${ }^{86}$ Ibid., 2.

${ }^{87}$ Ibid. 2.

${ }^{88}$ Ibid., 3.
} 
to the public, but also his injection of "political views into the ecumenical dialogue" which ought to have been reserved for theological discussion. ${ }^{89}$ Higgins saw these attempts as an effort to derail American Catholic-Jewish dialogue, especially by Ryan's painting them in opposition to the Vatican. Citing Ryan's speech, where he noted that "“while Rome has active and sensitive dealings with many groups, American Catholics have - with few exceptions - dealings only or mainly with American Jews,"' Higgins demonstrated the subtle misdirection Ryan hoped to achieve. Calling it a "faulty and very misleading comparison," Higgins pointed out that the Vatican was "expected to deal with all sorts of international groups," but this was not the case with the American Church. Rather, Higgins asserted that "the Church in the United States is expected to deal only with those groups in this country which want ecumenical relations." Consequently, it was a simple fact that there while there were "several million Jews in the United States, there [were] relatively few Arab Moslems" calling for dialogue with the American Church. ${ }^{90}$ In other words, it was a natural circumstance that the American Church would find itself in "dealings" with the Jewish community on a regular basis. Finally, Higgins pointed out that Ryan's use of a “"Palestinian-Jewish’ dichotomy” was a political, and not a religious, construction, and that because of this, ecumenical dialogue between Catholics and Palestinians was inherently contradictory.

It was for these reasons that Higgins requested that Ryan "stick" to being an "expert in the field of Arab culture," but that he "stop meddling in the field of Catholic-Jewish relations in this country." Noting that his knowledge of Catholic-Jewish relations was "extremely limited ... [and that] his point of view ... notoriously one-sided," he argued that Father Ryan "had lost all credibility with the Jewish community in the United States." As a consequence, Higgins argued

\footnotetext{
${ }^{89}$ Ibid., 2.

${ }^{90}$ Ibid., 3 .
} 
that "the less" Ryan said "about Catholic-Jewish relations in the American context, the better it [would] be for all concerned" in the effort of Catholic-Jewish dialogue. ${ }^{91}$ From Higgins' perspective, Father Joseph T. Ryan had no place in Catholic-Jewish relations.

\section{A Resolution of the Conflict: The Tenth Anniversary of Nostra Aetate}

Given the place of the Vatican in the conflict between the two Ryans, Flannery, and Higgins, it seems proper that the resolution to the conflict originated from the same source. On October 22, 1974, Pope Paul VI created a new organization for Catholic-Jewish dialogue, the Commission for Religious Relations with the Jews, of which Johannes Cardinal Willebrands served as its president. ${ }^{92}$ On December first of that year, the Commission published its own "Guidelines and Suggestions for Implementing the Conciliar Declaration 'Nostra Aetate,"” which sought to better define its own purpose and the purpose of the ongoing dialogue between Catholics and the Jewish community. The work itself was highly practical in nature, seeking not so much to micromanage the current dialogue between Catholics and Jews, but to define a structure in which such dialogue should take place. First and foremost, the document reiterated the main principles of Nostra Aetate. It rejected anti-semitism in all its forms, especially the charge of deicide made against the Jewish people as a whole. It advised caution in the performance of the liturgy and corresponding homilies, especially when "passages which seem to show the Jewish people ... in an unfavourable light" were in question, since such passages

\footnotetext{
91 Ibid., 4.

${ }^{92}$ Coincidentally, the newly formed Commission served as a branch of the Vatican's Secretariat for Promoting Christian Unity, of which Willebrands also served as president.
} 
could easily be misinterpreted and distorted by an inexperienced pastor. ${ }^{93}$ Finally, it called for greater education of Catholics in the Jewish tradition.

Perhaps the greatest contribution of the document for Edward Flannery and George Higgins - and the American Secretariat for Catholic-Jewish Relations - lay in its definition of dialogue, and the charge it placed upon the members of the Church engaged in it. The guidelines asserted that all Catholics had to "strive to acquire a better knowledge of the basic components of the religious tradition of Judaism," and by doing so, "strive to learn by what essential traits the Jews define themselves in the light of their own experience." 94 The import of this charge resided in the Commission's definition of dialogue, which was that dialogue "presupposes that each side wishes to know the other, and wishes to increase and deepen its knowledge of the other." Furthermore, Willebrands' Commission asserted that dialogue constituted "a particularly suitable means of favoring a better knowledge and, especially in the case of dialogue between Jews and Christians, of probing the riches of one's own tradition." Consequently, dialogue demanded the "respect for the other as he is; above all, respect of his faith and his religious convictions." 95

Certainly, such a description of dialogue by the new Vatican commission encouraged Higgins and Flannery in their own work, as they sought to convince the hierarchy that the land of Israel was an essential part of the Jewish faith. In their own minds, Israel was "an essential trait" by which the Jews "defined themselves in light of their own experience," and so deserved the respect of Christians as a part of the dialogue itself. ${ }^{96}$ Flannery himself described the document as a "long-delayed document ... worth waiting for," and noted that the document gave the

\footnotetext{
${ }^{93}$ The Vatican, "Guidelines and Suggestions for Implementing the Conciliar Declaration 'Nostra Aetate' (n.4)," http://www.vatican.va/roman_curia/pontifical_councils/chrstuni/relations-jewsdocs/rc_pc_chrstuni_doc_19741201_nostra-aetate_en.html (accessed on 10.15.2013).

${ }^{94}$ Ibid.

${ }^{95}$ Ibid.

${ }^{96}$ Ibid.
} 
American Secretariat "much to do in the years to come," as well as "a new and strong impetus to the promotion of Catholic-Jewish understanding and cooperation" in American dioceses. ${ }^{97}$ Meanwhile, Higgins pointed out how Willebrands' statement recalled the "spiritual bond linking the people of the New Covenant with Abraham's stock, the spiritual patrimony common to Christians and Jews," and how the declaration aimed "at promoting mutual understanding and respect between the two faiths, through brotherly dialogue, among other means." 98 More importantly, Willebrands' document provided the perfect impetus, along with the approaching tenth anniversary of Nostra Aetate, for both Higgins and Flannery to end the dispute concerning the place of Israel within Catholic-Jewish dialogue.

Fortunately for both Higgins and Flannery, the National Conference of Catholic Bishops' commemoration of the tenth anniversary of Nostra Aetate served as the means to solve their troubles with Joseph A. and Joseph T. Ryan. Both men undoubtedly knew the document was in development, as connected as they were with the Secretariat's own work in the field of CatholicJewish relations. Consequently, both Higgins and Flannery sought to include their developed theology of the Land in the statement, and by doing so, give their work in Catholic-Jewish relations the weight of the hierarchy as a whole. In order to do so, they needed to gain support within the body of bishops at their annual meeting.

Higgins did so by contacting the Archbishop of Atlanta, Thomas A. Donnellan. In his letter to the archbishop, Higgins noted that the upcoming statement mentioned the relationship between the Covenant and the land of Israel, and acknowledged that some within the body of

\footnotetext{
${ }^{97}$ United States Catholic Conference News, "Strengthening of Catholic-Jewish Ties Called For By The New Vatican Commission: Bishops' Spokesman Says Document 'Solidifies' Basis for Dialogue,” Dec. 30, 1974, http://old.usccb.org/seia/jw4.pdf (accessed on 10.15.2013).

${ }^{98}$ George G. Higgins, “Teach Me, O My God, To Look Upon Humanity As You Yourself Behold It...,"” The Yardstick, January 27, 1975, ACUA/GGH Papers, Box 291, Folder 1.
} 
bishops feared such a reference was too political in nature. Higgins did not agree with that sentiment, arguing that the Conference should "speak to the question of the 'land' from a theological point of view without taking sides on the strictly political aspects of the Middle East crisis." Furthermore, he felt that it was "absolutely essential ... that the proposed Conference Statement include a reference to the "land."' In fact, he felt so strongly about the need for such a theological treatment, that he argued that it "would be better for the Conference not to issue any statement at all at this time than to issue one which omitted any reference to the Jewish understanding of the relationship between the Covenant and the land." Consequently, he asked Donnellan to "speak to this issue at the November NCCB meeting should the need to do so arise." 99

Fortunately for Higgins and Flannery, they achieved their goal. In the following month, the National Conference of Catholic Bishops issued their Statement on Catholic-Jewish Relations commemorating the tenth anniversary of Nostra Aetate. Commending the work of the Secretariat and its implementation of the Guidelines for Catholic Jewish Relations issued in 1967, the NCCB acknowledged the work of the Secretariat which had "maintained fruitful contact with the major groups within the Jewish community, and had "been in regular communication with the dioceses of the country" on issues of Catholic-Jewish concern. ${ }^{100}$ Following its recognition of the Secretariat, the NCCB reiterated much of Willebrand's statement from the preceding year, and reaffirmed the core principles of Nostra Aetate. Rejecting anti-Semitism in all its forms, the Bishops' acknowledged that Christians had not "fully appreciated their Jewish roots," such as the "Jewishness of Jesus, of his mothers, his disciples, of

\footnotetext{
${ }^{99}$ George Higgins to Thomas Donnellan, October 30, 1975, ACUA/GGH Papers, Box 289, Folder 1.

${ }^{100}$ United States Catholic Conference, "Statement on Catholic-Jewish Relations: On the Occasion of the Celebration of the Tenth Anniversary of Nostra Aetate, No. 4," November 20, 1975, ACUA/GGH Papers, Box 289 , Folder 1, 2.
} 
the primitive Church." In response, the Bishops' statement urged "all in the Church who work in the area of education, whether in the seminary, the school or the pulpit, not only to avoid any presentation that might tend to disparage Jews or Judaism but also to emphasize those aspects of our faith which bear witness to our common patrimony and our spiritual ties with Jews."101 This included any charges of deicide against the Jewish community, for the bishops wanted to ensure "that nothing which in any way approaches the notion of Jewish collective guilt should be found in any Catholic medium of expression or communication." This command benefitted those of the Catholic faith, for bishops argued that "the disappearance of the charge of collective guilt of Jews pertains as much to the purity of the Catholic faith as it does to the defense of Judaism." ${ }^{102}$

But more importantly, the Bishops' recognized an ongoing, developing theology surrounding the place of Israel in relation to the Jewish community. Noting how Nostra Aetate supported theological and biblical studies in collaboration with Jews, the Bishops' statement asserted that such work was again meant for the benefit of the Church, since the "renewal of Christian faith" was the core of this movement, and that by its very definition "renewal always entails to some extent a return to one's origins." The exploration of "the continuing relationship of the Jewish people with God and their spiritual bonds with the New Covenant" was the task of Catholic theologians, particularly in light of the works of the apostle Paul. Accordingly, their commemoration of Nostra Aetate including the following passage:

Paul reveals his deep love of the Jewish people. He tells of his willingness to accept damnation itself for the sake of his kinsmen (9:3), even though he also expresses his painful disappointment and incomprehension at Israel's failure to accept Jesus as its Messiah. Crucial to an understanding of his admiration of the Jewish people and to a Christian understanding of their situation is the following text. Written at the midpoint of the first century, Paul refers to his "kinsmen

\footnotetext{
${ }^{101}$ Ibid., 3.

${ }^{102}$ Ibid.
} 
according to the flesh who are Israelites, who have the adoption as sons, and the glory and the covenants and the legislation and the worship and the promises; who have the fathers, and from whom is the Christ according to the flesh" (9:3-5), thus making clear the continuing validity of Israel's call. Paul, moreover, insists that God has by no means rejected his people. "Is it possible that God has rejected his people? Of course not. I, an Israelite descended from Abraham through the tribe of Benjamin, could never agree that God has rejected his people, the people he chose specially long ago" (11:1-2). What proof does Paul offer for the enduring validity of Israel's relationship to God even after the founding of the Church? "God never takes back his gifts or revokes his choice" (11:29)....

[We] find in the Epistle to the Romans (9-11) long-neglected passages which help us to construct a new and positive attitude toward the Jewish people. There is here a task incumbent on theologians, as yet hardly begun, to explore the continuing relationship of the Jewish people with God and their spiritual bonds with the New Covenant and the fulfillment of God's plan for both Church and Synagogue. ${ }^{103}$

Part of this task then had to be the exploration of the land in connection with the Jewish people's relationship with God, something which both Higgins and Flannery had worked so hard to achieve. In accordance with their analysis of Paul, the bishops recognized that "Jews... do not consider themselves as a church, a sect, or a denomination, as is the case among Christian communities, but rather as a peoplehood that is not solely racial, ethnic or religious, but in a sense a composite of all these," and it was for these "reasons that an overwhelming majority of Jews see themselves bound in one way or another to the land of Israel." This sense of identity was "essential to their Jewishness." Consequently, whatever "difficulties Christians may experience in sharing this view," it was their obligation to "strive to understand this link between land and people which Jews have expressed in their writings and worship throughout two millennia as a longing for the homeland, holy Zion." ${ }^{104}$ For the bishops, this was the basis of

\footnotetext{
${ }^{103}$ Ibid., 5.

${ }^{104}$ Ibid., 6.
} 
dialogue between Jews and Catholics, and in accordance with Nostra Aetate, it called for all Christians to participate in dialogue on this level.

Following Willebrands' definition of dialogue, the American bishops recognized the Jewish community as it was, a people spiritually tied to the land of Israel. It was a purely theological recognition, removed from the politically charged atmosphere that surrounded Israel's policies and territorial boundaries. Consequently, it did not "deny the legitimate rights of other parties in the region, or ... adopt any political stance in the controversies over the Middle East, which lie[d] beyond the purview of this statement." 105 However, what it did do was end the conflict between the two Ryans, Higgins, and Flannery. The bishops' statement affirmed the stance that Flannery and Higgins had maintained from the beginning. By acknowledging a theological dimension to the land of Israel, one tied to the personhood of the Jewish community, the bishops had recognized an implicit element of Catholic-Jewish dialogue, one that had to be acknowledged in order for dialogue to exist and move forward. Furthermore, by publicly accepting the need to acknowledge Jewish ties and theological "rights" to the land, while at the same time maintaining a strict distance from taking any political stance on the issue, Ryan was excluded from the conversation. The bishops' statement made it quite clear that they would not be involved in the politics of Israel as a nation, but in the same breath they affirmed that Israel was a part of the dialogue between Catholics and Jews and their shared heritage. Both Joseph A. Ryan and Joseph T. Ryan's arguments rested upon the political actions of the state of Israel; the bishops had made clear this was not a part of the dialogue between the two communities they were willing to address.

${ }^{105}$ Ibid. 
Higgins must have been pleased with the outcome. Not only did he and Flannery achieve their goal of settling the dispute over the place of Israel in Catholic-Jewish dialogue, but he had helped foster an environment which encouraged Catholics to better understand themselves in light of another faith. By doing so, Higgins had helped the American Church achieve one of the main directives of the Second Vatican Council, which was to engage in dialogue with people of all faiths in the effort to resolve the modern problems of their day. Finally, on a more personal level, Higgins had helped define for the American Church that which he believed Nostra Aetate had lacked - a clearer and stronger statement refuting the charges of deicide against the Jewish people.

The work Higgins performed on behalf of the American Catholic Secretariat for CatholicJewish Relations was not an interlude from the demands of the American labor movement, however. It was during this same period that a new labor conflict was rising up in the fields of California, led by Cesar Chavez and his union, the United Farm Workers of America. Higgins would have a role to play in the conflict between Chavez and the growers as well, which the following chapter will examine. 


\section{Chapter 8}

\section{A Return to Labor Conflict: The United Farm Workers' Movement and the Bishops' Ad Hoc Committee on Farm Labor}

Monsignor Ryan ... took the position that a boycott is legitimate 'when the injustice inflicted by the employer is grave, and when no milder method will be effective. To deny this would be to maintain that the employer has a right to pursue his advantage in an unreasonable way, and immune from reasonable interference. The laborers are endowed with the same right of seeking material benefits on reasonable conditions and by reasonable methods; in this case the boycott is a reasonable method.'

In my judgment, the California grape boycott is a perfect case in point. I therefore wholeheartedly support it and hope that it will soon achieve its one and only purpose, namely, to persuade the growers, at long last, to recognize their workers' right to organize.

- $\quad$ Rev. George G. Higgins, The Yardstick, January 6, 1969 $\phi$

The Secretariat for Catholic-Jewish Relations was not the only social issue Higgins addressed following the Second Vatican Council. On the opposite side of the country Cesar Chavez and the National Farm Workers Association (NFWA) were fighting for the rights of the farm workers of California, and had been met with complete resistance by the growers of Delano County. At the heart of the issue between the NFWA and the growers lay the basic principle of economic selfdetermination. While the majority of industries had gained the rights to organize and bargain collectively under the National Labor Relations Act of 1935, the act had excluded farmworkers from its protection. Consequently, growers of the United States could refuse to recognize agricultural unions, and take measures to prevent their organization. Meanwhile, the farm workers had no legal standing to force growers into negotiations. 
Higgins and the SAD had been calling for agriculture's inclusion within the National Labor Relations Act since his first days as a member of the department. The effort was part and parcel of the Industry Council Plan promoted by both McGowan and Higgins, a plan which envisioned the "existing organizations of labor, management, agriculture and the professions" joining together and cooperating with each other "in a federated system of industrial and professional councils specifically designed to facilitate the practice of social justice by consciously promoting the general welfare of the common good." ${ }^{\prime 1}$ As part of this effort, the SAD hoped to amend the NLRA and extend its principles "of business-labor cooperation to agriculture and to the professionals," so that "all four groups [would strive] for mutual cooperation."2

Besides such efforts, Higgins positioned himself as an authority on migrant farm labor in the United States, particularly in relation to the bracero programs. Initiated during the Second World War, the programs compensated for a shortage of farm workers by bringing in Mexican workers during the harvest seasons. The intent of the program was to offset the loss of American farm workers, who were fighting for their country instead of harvesting the fields, and was meant to cease following the end of the war. However, given the programs immense popularity among the growers, these programs were extended by Congress regularly. The bracero programs gave growers near total control over their workforce during the years of its implementation. Migrant

\footnotetext{
${ }^{1}$ George G. Higgins, "Reconstruction through Industry Councils," The Yardstick, May 1, 1961, ACUA/GGH Papers, Box 347, Folder 6.

${ }^{2}$ Social Action Department, "Confidential Brief on the Taft-Hartley Act," ACUA/USCCB SAD Papers, Box 14, Folder 15, 1.
} 
workers who challenged the growers were simply deported and replaced; the labor supply was so vast and cheap that replacing workers presented little challenge to the growers. ${ }^{3}$

As both Assistant Director and Director of the SAD, Higgins fought these programs, arguing that the system was essentially an accepted form of peonage in the United States. While the bracero workers were not tied to the land by debt, the workers were unable conscionably to leave those jobs due to the economic hardships their families faced in Mexico. At the same time, the wages the growers provided only maintained the economic standing of the workers, and did not enable them to escape their plight. Moreover, growers consciously offered a wage rate so low as to guarantee that no domestic workers would apply for employment. In turn, this practically assured migratory labor for their fields. Consequently, Higgins once again advocated the inclusion of agricultural workers under the umbrella of the NLRA, which would require the growers to provide unemployment benefits, workers' compensation, minimum wage requirements, and child labor protections. Besides advocating such changes, Higgins also called for the end to the bracero programs, so that growers would be forced to hire American agricultural labor once again, as opposed to having a cheap and limitless source of labor from Mexico. $^{4}$

Higgins got his opportunity to effect real change when he became a member of the Mitchell Committee on Migratory Labor in 1959. Created by James P. Mitchell, the Secretary of Labor for President Eisenhower, the Committee evaluated the current incarnation of bracero legislation, Public Law 78. Besides Higgins and Mitchell, the Committee included Edward J. Thye, the former U.S. Senator of Minnesota; Glenn E. Garrett, the chairman of the Texas

\footnotetext{
${ }^{3}$ Marco Prouty, "Cesar Chavez and the Catholic Civil War, 1965 - 1977" (PhD diss., Catholic University of America, 2004), 43 - 45.

${ }^{4}$ Ibid., $49-50$.
} 
Council on Migrant Labor; and Dr. Rufus B. Bon Kleinsmid, the chancellor of the University of California. The Committee's findings condemned the United States government's role in creating and fostering an environment that supported the degradation of migrant workers who had no other financial alternative. Consequently, the Committee advocated that the end of the bracero programs through a series of gradual reforms meant to wean American agriculture from its dependency on migratory labor. Acting upon the Committee's recommendations, Congress finally decided not to renew the law, which expired on Dec. $31,1964 .^{5}$

By working for the end of the bracero program, Higgins helped create the conditions that allowed Cesar Chavez to succeed in his fight against the growers of California. With the end of the Public Law 78, the strike once again became a formidable weapon for those attempting to organize the farm workers and bargain collectively. Growers could no longer use cheap immigrant labor to circumvent any strikes domestic labor might pursue. This included the efforts of Cesar Chavez and the National Farm Workers Association, which Chavez had formed on September $30^{\text {th }}$, 1962. Within one year of the end of Public Law 78, the NFWA joined a fellow union, the Agricultural Workers Organizing Committee, in its strike against the grape growers of Delano, California on September $16^{\text {th }}, 1965 .{ }^{6}$ Within a year, the two unions had joined to become the United Farm Workers Organizing Committee (UFWOC), and the strike became a mainstay in their effort to gain better working conditions for the farmworkers.

The struggle between the growers of California and the UFWOC was an inherently Catholic conflict, as the majority of growers and farm workers were Catholic. Certainly, Chavez interpreted it as such. Having learned the social teachings of the Church in his formative years

\footnotetext{
${ }^{5}$ Ibid., $66-72$.

${ }^{6}$ Ibid., v.
} 
from a visiting Catholic priest, he applied these principles to the formation of the NFWA in 1962. Moreover, Catholic liturgical practices served as a means to organize the farm workers, demonstrated by Chavez's fasts, pilgrimages, and reliance upon the Mass to gather and unify those in the fields. For Chavez, the conflict between the farm workers and the growers was as much a battle over religious values as it was a battle for trade union rights. Unfortunately, his efforts were met with complete resistance by the growers of Delano, who not only refused to bargain with Chavez and his union, but refused to recognize their right to organize in the first place. Further complicating matters, grower donations contributed a significant portion of the diocesan budget in California, and as a group they expected the Church to remain silent on the issue. In turn, Chavez expected the aid of the Church in his efforts to gain recognition and bargain collectively.

Fortunately for Chavez, Higgins was determined to gain the bishops' support of the farm workers in their struggle for economic justice. Higgins's backing of Chavez was instrumental in shaping the hierarchy's conversation of how to approach the conflict between the UFWOC and the growers, and ultimately led to the creation of the Bishops Ad Hoc Committee on Farm Labor in November of 1969. Since agriculture did not fall under the NLRA, neither the growers nor the UFWOC had the benefit of an outside party to mediate the conflict. The Committee fulfilled that role. By mediating the conflict, the Committee did much more than simply aid in the negotiations between the growers and the farm workers, however. It also forced all parties to recognize the social teachings of the Church, especially the right to organize and bargain collectively. The Committee was initially successful in this regard, but accusations of partisanship and the introduction of a competing union, the Teamsters forced the Committee to abandon its efforts of mediation. 
During the course of the conflict, Higgins's opponents accused him of betraying the Committee's intended neutrality, and subverting the Committee to Chavez's cause. Given that Higgins initially supported the boycott, such accusations warrant serious consideration.

However, upon further review the record shows that Higgins abided by his role as a mediator, insofar as he understood it. First and foremost, Higgins - along with the remainder of the Committee - established from the start that the rights of the farmworkers to organize and bargain collectively were not in question. The recognition of such rights was the established teaching of the Church, and as such was not open to discussion. If the growers and the UFWOC wanted to take advantage of the Committee's offer of mediation, then the recognition of these rights was an inherent part of the process. Along the same lines, Higgins's defense of Chavez and his union may be best understood in his role as a mediator. Higgins believed that a mediator was not simply someone who facilitated negotiations between parties, but who also managed the conflict between them. It was this understanding that led Higgins to defend Chavez from personal attacks, or what he described as "hatchet jobs." Such attacks threatened to derail the ongoing negotiations between the growers and the UFWOC, because at the heart of these attacks was the insinuation that Chavez's union was not actually a union at all. Instead, it was simply a social movement. By making such an argument, Chavez's opponents hoped not only to undermine his credibility at the negotiating table, but if possible, prevent any negotiations from actually taking place. In response, Higgins argued that the UFWOC was a valid union, and that its religious identity represented the best that the labor movement had to offer. Finally, while it is undeniable that the Committee endorsed Chavez's boycott, this action did not represent partisanship favoring Chavez. Instead, it was a declaration of solidarity with the farmworkers and their efforts to gain the right to organize and bargain collectively. The actions of the Teamsters and the 
growers had circumvented the wishes of the farmworkers, and had once again denied their right

to economic self-determination. In response, the bishops endorsed the boycott in order to secure

free, secret ballot elections which would not only recognize the economic rights of the

farmworkers, but would determine once and for all which union, if any, the farmworkers wanted for representation.

\section{Setting the Stage: The History of the Bishops' Ad Hoc Committee and Its Role in Settling the Dispute between the Farmworkers and Growers of California}

By November of 1969, the UFWOC had fought for over five years with the grape growers of

Dern County, California in their effort to secure better wages and working conditions for the

farmworkers in Delano. While the strike served as a primary tool that the UFWOC utilized in its

attempt to such gains, it was the UFWOC's boycott that drew national attention to the cause of

the farmworkers. ${ }^{7}$ Chavez and the UFWOC conducted primary and secondary boycotts of all

Delano grapes, meaning they asked their supporters not only to boycott the grapes themselves,

but any businesses that sold them. The National Labor Relations Act's failure to include

\footnotetext{
${ }^{7}$ The majority of the history of the United Farm Workers and its relationship with the Bishops' Ad Hoc Committee on Farm Labor, which includes the actions of George Higgins in his role as its consultant, has been written by Marco G. Prouty. Originally written as his dissertation at the Catholic University of America, the work was later published by the University of Arizona Press as Cesar Chavez, the Catholic Bishops, and the Farmworkers' Struggle for Social Justice. In both works Prouty argues that Higgins and the Committee were pro-Chavez, and partisan to the cause of the United Farm Workers. Prouty supports this assertion by citing Higgins' public support of Chavez, his initial endorsement of Chavez's boycott prior to the creation of the Committee, and the eventual endorsement of the UFW boycotts by the Committee at the 1973 annual meeting of the hierarchy. Prouty's work was written prior to the organization of the George Higgins Papers at Catholic University Archives, however. As a consequence, it appears that he missed certain documents that challenge his interpretation of events. Additional documentation provides a more nuanced view of the actions of George Higgins in relation to the Ad Hoc Committee, which in turn challenges Prouty's interpretation of the actions of the Committee as a whole. Neither Higgins nor the Committee acted as partisan to the UFW in their role as mediators. Their actions were consistent with the social encyclicals, insofar as they maintained the right to organize and bargain collectively. These were intrinsic human rights defined by the Church, and the actions of Higgins and his fellow Committee members as mediators were based upon their recognition of these principles. Following the recognition of these rights, the actions of Higgins and the Committee demonstrate their commitment to mediating the conflict as a neutral third party. Consequently, Prouty's argument that portrays Higgins and the Committee as partisan is misleading.
} 
agricultural workers as part of its legislation allowed Chavez and his union to employ such a tactic. Their lack of inclusion meant that the Taft-Hartley amendment, with its restrictions of secondary boycotts and mass picketing did not apply to the UFWOC. ${ }^{8}$ UFWOC organizers spread throughout the country, particularly in New York, picketing those chains which sold Delano grapes, while at the same time informing the public of their cause. Chavez also garnered interdenominational religious support of the boycott, ranging from individual ministers, bishops, and rabbis, to larger representative groups like the National Council of Churches. In August of 1968, Chavez and the UFWOC asked the United States Catholic Conference (USCC) to do the same. Addressing Bishop Joseph Bernardin, the General Secretary of the USCC, Chavez requested that the American Catholic Church and its diocesan institutions endorse the boycott of grapes from California growers. Given that the majority of both the farmworkers and the growers were Catholic, Chavez's request was hard to ignore. ${ }^{9}$

In his role as director of the Social Action Department of the USCC, Higgins supported the boycott and advocated its endorsement by the bishops. Unfortunately for Chavez, two bishops from California opposed Higgins in this regard, Bishops Timothy Manning of Fresno and Hugh Donohoe of Stockton. Both Manning and Donohoe argued that the church had to consider both groups involved in the conflict, especially the small growers who did not have the same advantages that larger agribusiness owners had. As a direct result, the bishops requested that Higgins draft a statement for their November $14^{\text {th }}$ meeting which acknowledged both sides of the California farm labor dispute, and indicated they would not endorse the boycott. Consequently, the overarching goal of the 1968 statement published by the united body of

\footnotetext{
${ }^{8}$ Marco Prouty, Cesar Chavez, The Catholic Bishops, and the Farmworkers' Struggle for Social Justice (Tuscon: University of Arizona Press, 2006), 28.

${ }^{9}$ Ibid., 48 .
} 
bishops was that it sought to "address ... the problem [of the farm labor conflict] with the high hope of assisting in a reconciliation between grower and worker," and part and parcel to this effort was the application of Catholic social teaching to both sides of the conflict. ${ }^{10}$

In doing so, the statement recognized the farmworkers' right to organize and bargain collectively, and called upon the federal government to include agricultural workers under the NLRA and minimum wage laws. Quoting the Pastoral Constitution of the Church in the Modern World, it affirmed the right to strike as "a necessary, though ultimate, means for the defense of the workers' own rights, and the fulfillment of their just demands," but at the same time acknowledged the difficulties small farmers faced economically. ${ }^{11}$ The bishops were conscious of the fact that the small grower was "often the victim of circumstances beyond his control," so much so that his "willingness to pay higher wages" was often met with "obstacles which he cannot overcome without a realistic coordination of all his strength." Consequently, the bishops recommended that both parties find a way to work together to solve their differences, and reminded both groups that the role of the Church was to "encourage dialogue by helping to create an atmosphere of charity and justice." It was for this reason that the bishops, quoting the Pastoral Constitution once again, hoped "that ways can be found at the earliest possible date 'to resume negotiations' and to bring about a 'reconciliation' between the parties to the current labor

\footnotetext{
${ }^{10}$ United States Catholic Conference, "1968 Statement on Farm Labor,” November 13, 1968, ACUA/GGH Papers, Box 235, Folder 8.

${ }^{11}$ The Decree of the Pastoral Constitution of the Church in the Modern World, as quoted in the United States Catholic Conference, "1968 Statement on Farm Labor," November 13, 1968, ACUA/GGH Papers, Box 235, Folder 8.
} 
dispute." As a united body, the bishops pledged their "united efforts to achieve this objective."12 As a result, Chavez did not receive his endorsement. ${ }^{13}$

While the bishops did not endorse the boycott, the statement was still well received by both Chavez and the UFWOC. Not only had the bishops endorsed the right to organize, but they had supported the right to strike after collective bargaining had failed. From Chavez's perspective, not only had collective bargaining failed, but it had never even been given a chance. The growers refused to acknowledge the union's right to organize, or for that matter, bargain collectively. Consequently, for Chavez and the UFWOC, the bishops' statement was a document that demonstrated support for their right to organize and bargain collectively. ${ }^{14}$ Nonetheless, Chavez refused to give up his request for the bishops' endorsement of the boycott, and repeated his call to the bishops that following year. Chavez argued that the need for the bishops' endorsement of the boycott was more pressing than ever, and asserted that no serious negotiations had occurred since their statement. Collective bargaining could not occur because the growers refused to bargain with the union.

Yet again, Bishops Donohoe and Manning opposed official backing of Chavez's boycott. Prior to the meeting, both bishops argued that such an endorsement would wreck any possibility of reconciliation between the growers and farmworkers. Instead of supporting the boycott, both bishops proposed their services as mediators. Higgins was more than willing to let them try their hands at such a task, and set up a meeting between Donohoe and William Kircher, the AFLCIO's Director of Organization. The meeting was fortuitous. Kircher supported such a role by the bishops in an effort to end the dispute, and convinced Donohoe that such action would be

\footnotetext{
${ }^{12}$ United States Catholic Conference, “1968 Statement on Farm Labor,” November 13, 1968, ACUA/GGH Papers, Box 235, Folder 8.

${ }^{13}$ Prouty, Cesar Chavez, The Catholic Bishops, and the Farmworkers' Struggle, 48-50.

${ }^{14}$ Ronald B. Taylor, Chavez and the Farm Workers, (Boston: Beacon Press, 1975), 167 - 168.
} 
beneficial to both grower and farmworker. This was the genesis of the Bishops' Ad Hoc Committee on Farm Labor, established at the end of the November, 1969 annual meeting of the bishops.

The two California bishops repeated their case at that meeting, arguing that the united body of bishops had to demonstrate concern for all of their flock, growers and farmworkers alike. Both Donohoe and Manning argued that the Church had already garnered the perception of being in favor of the farmworkers to the detriment of the growers, and that it was the Church's place to build a bridge between the two. An endorsement of the boycott would have only served to polarize an already delicate situation, and prevent any form of mediation offered by the Church. The two bishops noted that other religious organizations had been sidelined from the conflict for that very reason, effectively preventing any positive social action on their part, aside from the public support that they had given Chavez and the UFWOC. As a result, Cardinal John Francis Dearden, President of the National Conference of Catholic Bishops, ordered the establishment of the Bishop's Ad Hoc Committee on Farm Labor. The committee consisted of five bishops and was charged with two primary tasks: first, to investigate the conflict between the growers and the farmworkers; and second, to use this knowledge to persuade the two groups to return to the bargaining table. To aid them in this goal, the body of bishops, along with Dearden, gave the committee the authority to take any actions it deemed appropriate in this regard, including any statements necessary on behalf of the hierarchy as a whole. As might be expected, Bishops Donohoe and Manning were assigned to the committee, as well as Auxiliary Bishop Joseph Donnelly of Hartford, Connecticut, Bishop Humberto Medeiros of Brownsville, Texas, and Bishop Walter Curtis of Bridgeport, Connecticut. The committee members chose Bishop Donnelly as their chairman due to his extensive experience in labor disputes, and in turn 
Donnelly asked Higgins to serve as a consultant, which Higgins readily accepted. Msgr. Roger Mahoney, who already had served as a diocesan priest under both Manning and Donohoe, acted as the committee's secretary. ${ }^{15}$

The committee held its first meetings in February of 1970, and over the course of the next four months met with approximately 60 growers of Delano, California. While conducting their investigation, the committee found that few growers, if any, were inclined to recognize the existence of the UFWOC as a union, and instead maintained that their workers did not desire any union representation. This reluctance to recognize Chavez and the UFWOC lessened over time, however, as the boycott progressed. During the course of the investigation sales of table grapes plummeted, and it was this pressure that helped bring the growers to the bargaining table. Growers soon began to take up the Ad Hoc Committee's offers of mediation in the dispute. Once the Ad Hoc Committee became involved in negotiations, the benefits of the bishops' presence became evident. In particular, the influence of the bishops, along with Higgins, offset Chavez's negotiating style, a style that the growers were wholly unprepared to handle. Chavez often allowed numerous union members to attend negotiations, members who would interject their own opinions and demands at completely random intervals. Furthermore, Chavez and his union had gained a reputation of non-negotiation, instead making demands without any consideration of compromise. Consequently, as the Ad Hoc Committee mediated more and more sessions, its reputation grew throughout the grower community. More often than not, growers would only negotiate as long as the Committee was available and present.

The negotiations mediated by the Committee were extremely successful. In April of 1970, Lionel Steinberg, Coachella Valley's largest grape grower, signed a contract with the

\footnotetext{
${ }^{15}$ Prouty, Cesar Chavez, The Catholic Bishops, and the Farmworkers' Struggle, 54 - 57.
} 
UFWOC. The following month, the Bianco Fruit Company and the Bruno Disopoto Company did the same. In June, other agricultural businesses followed, among them the June Roberts Farms, Inc., the S.A. Camp Company, and Tenneco. By the end of July, the majority of Delano's growers had all signed with Chavez and the UFWOC, and the remainder had agreed to enter contracts as soon as the boycott ended. The Bishops' Ad Hoc Committee mediated each and every bargaining session. ${ }^{16}$ Unfortunately, no sooner had the UFWOC signed the remaining contracts with the majority of growers that a new conflict arose.

The Western Conference of Teamsters had signed "sweetheart deals" with the majority of lettuce growers in Salinas Valley, and their contracts covered some 5,000 farmworkers. To make matters worse, these contracts had been signed without the approval of any of the farmworkers they purported to represent. Besides this lack of approval, the growers' contracts stipulated that only the Teamsters could bargain on behalf of the farmworkers, making the union the farmworkers' sole agent. Nor were the actions of the Teamsters honorable, for in the process of signing agreements with the Salinas growers, they had also broken a jurisdictional pact they had signed with the UFWOC in 1967. Traditionally, the Teamsters had only concerned themselves with those occupations related to the fields, as opposed to the fieldworkers and the fields themselves. Accordingly, on July 21, 1967 the UFWOC took control of the fields through an agreement signed with the Teamsters, and at the same time surrendered jurisdiction over any canneries, creameries, frozen food plants, producer markets, and warehouses. By signing contracts with the growers, it was a clear message to Chavez that the both the growers and the Teamsters sought to replace the UFWOC as the bargaining agent for the farmworkers. ${ }^{17}$

\footnotetext{
${ }^{16}$ Ibid., $58-64$.

${ }^{17}$ Ibid., 67 - 68 .
} 
Chavez immediately requested that the Bishops' Ad Hoc Committee serve once again as mediators in the anticipated dispute. Donnelley, Higgins, and the other members accepted. On August $11^{\text {th }}$, the Teamsters and the UFWOC met to reconcile their differences, and with the aid of the Committee signed an agreement re-establishing their 1967 arrangement. The peace would not last. Within two weeks of its signing, the president of the Grower-Shipper Vegetable Association (GSVA) announced that the contracts with the Teamsters were not only valid, but that both parties had agreed to honor them. The Ad Hoc Committee's efforts towards mediation were for naught. Chavez responded on August $24^{\text {th }}$, calling a massive strike of those lettuce farms who had signed with the Teamsters. Approximately 6,000 farmworkers walked away from the fields, leaving almost 150 lettuce farms without any workers. ${ }^{18}$

The actions of the Teamsters following their 1970 mediation with the UFWOC foreshadowed a pattern of conduct that would remain constant throughout the conflict. Every time the Bishops' Ad Hoc Committee mediated between the two unions, the Teamsters would inevitably renege on the agreement. In certain instances, the Teamsters even used these negotiations to the growers' advantage, timing negotiations around the harvest so that Chavez would agree to end his strike as a measure of good faith. Once the harvest had concluded, the Teamsters would once again reverse course. Such was the case in March of 1971, when the Teamsters and the UFWOC attempted once again to renew their jurisdictional contracts. The overture was merely a diversionary tactic, however. During the course of negotiations the Teamsters convinced Chavez to put aside his boycott as a good faith measure, and in return they drew out the negotiations just long enough for the growers to conclude the season without major

\footnotetext{
${ }^{18}$ Ibid., $69-70$.
} 
losses. Upon the end of the season, the union simply withdrew from negotiations with the UFWOC. ${ }^{19}$

The Teamsters were nothing if not consistent in this regard. In April of 1973, they once again signed sweetheart deals, but this time with the Delano grape growers who had signed with Chavez in 1970. Much the same as before, the Teamsters had not consulted any of the farmworkers of those fields, and simply claimed representation over them. ${ }^{20}$ Chavez immediately called a strike, and reinstated his boycott of table grapes. Despite all the betrayals committed by the Teamsters, Chavez's union, now known as the United Farm Workers of America, AFL-CIO (UFW), returned to the bargaining table yet again in September of 1973 with the hope of resolving the Teamsters' seizure of their grape contracts. ${ }^{21}$ Once again, an agreement was reached, whereby the Teamsters agreed to abandon their contracts with the grape growers, and in exchange the UFW would yet again halt its lettuce boycott. Once again, the Teamsters reneged on the contract. Within two months, Frank Fitzsimmons, the President of the Teamsters, declared that the Teamsters had a legal obligation to honor their contracts, and that the union intended to do just that. More so, Fitzsimmons announced that any and all truces with the UFW were finished, and that Teamsters had no interest in further peace negotiations. The tactics of the Teamsters and the growers were clear. They sought to bury the UFW. ${ }^{22}$

Unfortunately for the Committee members, their work during this period of conflict was further complicated by the objections of a number of priests who took the side of the growers and the Teamsters. As a general rule, the priests in question attacked Higgins and the Ad Hoc

\footnotetext{
${ }^{19}$ Ibid., 74.

${ }^{20}$ Ibid., $88-90$.

${ }^{21}$ In February of 1972, the UFW became a charter of the AFL-CIO, and changed its name to the United Farm Workers of America, AFL-CIO.

${ }^{22}$ Prouty, "Cesar Chavez and the Catholic Civil War," 189 - 190.
} 
Committee, arguing that they sided with Chavez and his cause. More often than not, the priests also accused the Committee of overstepping its authority, and acting without the consent of the national hierarchy. Along with these accusations was the implication, or at times the outright charge, that the actions of the Committee were damaging to the Church. By siding with the growers, these priests undercut the authority of the Committee as representatives of the Church, and allowed the growers and Teamsters to claim as much to the general public.

Two of these priests, Fathers Daniel Lyons, S.J., and Cletus Healy, S.J., used the conservative weekly, Twin Circle, as their medium in support of the growers. The paper, founded in November of 1967, had approximately 100,000 subscribers during the farmworker struggle, and sought to present a conservative Catholic viewpoint in contrast to what it believed was the Committee's liberal leanings. As part of this policy, Twin Circle painted Higgins as a Chavez partisan and a proponent of compulsory unionism. Both Lyons and Healy pushed this point repeatedly, and portrayed Chavez as a veiled communist who did not have the support of the workers, or the clergy of California. To make matters worse, Twin Circle argued that Chavez had gained the Committee's support through subterfuge, and that Higgins served as a co-conspirator in that effort. The conflict between Lyons and the Committee progressed to such an extent that the Committee accused Twin Circle of purposefully misleading its readership on the issue. As a result, the chairman of Twin Circle's board, Archbishop Robert Dwyer of Portland, Oregon, requested and received Lyons' resignation. $^{23}$

Meanwhile, Father Mike Cross, a priest from Salinas Valley, publicly questioned the effectiveness of the Committee, and argued that its actions only served to turn the laity against the Church. Writing Cardinal John Dearden, the president of the NCCB, Cross asserted that the

\footnotetext{
${ }^{23}$ Prouty, Cesar Chavez, The Catholic Bishops, and the Farmworkers' Struggle, 33 - 35.
} 
Committee had exceeded the authority granted to it by the NCCB. Furthermore, he argued that the Committee sought to push the agenda of the UFWOC, and as a consequence had lost all credibility of neutrality. Even after being reprimanded by his bishop, Harry Clinch of Monterey, California, Cross refused to drop the matter. He continued to argue that the Committee's role was contrary to that of a peacemaker. He was later joined by the vicar general of the diocese of Monterey, Fr. Thomas Earley. As a duo, they supported the growers' side of the story presented in a pamphlet titled "The Lettuce Story," which argued that the UFWOC was attempting to monopolize all agricultural unions in order to control the nation's food supply. Insofar as the Ad Hoc Committee was concerned, the "Lettuce Story" accused them of being "poorly informed churchmen" who had exceeded the jurisdiction outlined by the national hierarchy. By supporting the growers, both Cross and Earley presented themselves as the informed churchmen on the conflict, and were used by the growers to support their own cause. ${ }^{24}$

Such was the atmosphere surrounding the conflict during the period from 1969 to 1973. Following the September, 1973 Teamster betrayal, the Bishops' Ad Hoc Committee advocated that the united body of bishops reverse course and support Chavez's boycotts. At the November annual meeting of the body of bishops, Bishop Donnelley, acting as chairman of the committee, argued that the Teamsters' recent actions demonstrated its true motives, which was to wipe out the UFW. The California growers were guilty by association as well, obviously colluding with the Teamsters in this goal. To make matters worse, the actions of the growers and the Teamsters ignored the economic wishes of the farmworkers, who by all investigative accounts preferred the UFW as a union in opposition to the Teamsters. The bishops, agreeing with Donnelley's assessment, endorsed the UFW boycotts of head lettuce and table grapes until the Teamsters and

\footnotetext{
${ }^{24}$ Ibid., $35-40$.
} 
growers agreed to secret ballot elections. ${ }^{25}$ Such action was the only viable method to determine once and for all which union the farmworkers preferred, or whether they even preferred unionization, which the bishops considered a basic "right of the field workers in the agricultural industry.",26

Two years passed before the bishops rescinded their support of the boycott at the 1975 annual meeting of the hierarchy. The California Labor Relations Act (CALRA), passed on June 5,1975 , met the demands of the hierarchy by allowing the agricultural workers of California to decide which, if any, union representation they wanted. The Act was the signature legislation of Jerry Brown, the Democratic governor of California, and it was meant to end the farmworker, grower, and union conflict that had dominated California for almost a decade. The CALRA, besides guaranteeing secret elections for agricultural workers, also established the California Agricultural Labor Relations Board (CALRB). This board observed all union elections covered by the act, and set up the necessary structures needed to resolve any conflicts which might result from those elections. The bill enjoyed support from all parties in the conflict, as it addressed their particular needs in relation to the others. Growers were guaranteed protections from strikes and boycotts until elections had taken place and were recognized by the board, while the Teamsters were granted guarantees on their current contracts until elections had taken place and the farmworkers had decided their union representation. Chavez and the UFW were guaranteed that the elections would take place, that they would be supervised by an impartial party, and that the state would enforce the results of those elections. ${ }^{27}$

\footnotetext{
${ }^{25}$ Prouty, Cesar Chavez, The Catholic Bishops, and the Farmworkers' Struggle, 102 - 103; Prouty, "Cesar Chavez and the Catholic Civil War," 268 - 271.

${ }^{26}$ National Conference of Catholic Bishops, "Resolutions Passed by the National Conference of Catholic Bishops," November 16, 1973, ACUA/GGH Papers, Box 241, Folder 5.

${ }^{27}$ Prouty, Cesar Chavez, The Catholic Bishops, and the Farmworkers' Struggle, $114-119$.
} 
The governor nominated the members of the CALRB, which consisted of five members total: Roger Mahoney, the secretary of the Bishops' Ad Hoc Committee, who had also been elevated to the position of auxiliary bishop of Fresno in January of that year; LeRoy Chatfield, who had worked with Chavez and the UFW from 1963 to 1973; Joesph R. Grodin, professor of law at Berkeley University; Richard Johnsen, Jr., the vice-president of the Agricultural Council of California; and Joe C. Ortega, the director of a poverty agency in Los Angeles. Based on its composition, Brown sought to balance out the members of the conflict. Two members of the board represented growers' interests, while two other members represented the farmworkers. As a consequence, this meant the fifth member, who would serve as the Board's chairman, was meant to be neutral to the conflict. Unfortunately, neither the Teamsters nor the growers received Brown's choice for the chairman, Bishop Roger Mahoney, as neutral. By this time, both of these parties interpreted the actions of the Bishops' Ad Hoc Committee as partisan to the UFW, and argued that Mahoney's inclusion weighted the board too heavily in the UFW's favor. ${ }^{28}$

The creation of the CALRB, however, did not satisfy Chavez. Prior to the annual meeting of the hierarchy in November of 1973, Chavez wrote the bishops once again, asking that they continue to support the boycott. Chavez acknowledged that the creation of the CALRA was beneficial for the UFW, and that the origins of its formation were largely in response to the boycott. He argued that the growers had already begun to subvert the CALRB supervised elections through farmworker intimidation, and that the general counsel to the board, Walter Kintz, a former staff and regional attorney for the National Labor Relations Board, sought to undermine it by protecting the growers. ${ }^{29}$ Chavez feared that the end of the bishops' support of the boycott would embolden both the growers and the Teamsters, allowing them to claim a loss

\footnotetext{
${ }^{28}$ Ibid., $123-124$.

29 "Death Notice: Walter L. Kintz," San Francisco Chronicle, December 1, 2006.
} 
of support for the UFW. Such a development would only serve to hurt the morale of the union, while encouraging the growers and Teamsters to avoid negotiations. Consequently, Chavez believed the continuation of the boycott remained essential for the UFW's survival. ${ }^{30}$

Chavez's argument did not carry the day at the annual meeting of the bishops. The bishops hailed the passage of the CALRA, and congratulated all those involved in its passage through the California legislature. As part of its "Resolution on Farm Labor," the NCCB congratulated the farmworkers for gaining the right to determine union representation through secret elections, and called upon all parties to honor the spirit and letter of the law. Finally, since the farmworkers had now won the right of economic self-determination, the bishops publicly acknowledged that the conditions for supporting the boycott had been met, and with that their support of the UFW boycotts had come to a close. ${ }^{31}$

Predictably, the CALRA and its board did not end the agricultural conflict in California, but simply changed its venue from the fields to the legislature. Given the sheer volume of elections and the demands those elections presented, the CALRB exhausted its budget within three months of its opening. While the legislature granted an additional subsidy of $\$ 1.2$ million, this funding fell short of the electoral needs of the parties involved. The CALRB was simply swamped with election requests, as well as the disputes that often took place after the polls had closed. By and large, the election results were overwhelmingly in the UFW's favor, and as a result, the growers exerted their influence over the legislature to prevent any additional funding for the organization. The underfunding of the board proved to be a constant problem, so much so that many of its employees resigned in frustration due to lack of pay. Making matters worse, the

\footnotetext{
${ }^{30}$ Prouty, Cesar Chavez, The Catholic Bishops, and the Farmworkers' Struggle, 121 - 122.

${ }^{31}$ Ibid., $122-123$.
} 
growers found ways to determine how the farmworkers had voted, and punished them for voting for the UFW. Besides such punitive actions, even when the UFW had won representation by election, growers simply refused to sign collective bargaining agreements. The growers could rely on their legislative influence - and deeper pockets - to prevent the board from taking action in support of the UFW. ${ }^{32}$

Insofar as the UFW's relationship with the Teamsters was concerned, resolution finally came in the form of yet another agreement between the two unions, signed on March 10, 1977. Unlike the previous agreements between the UFW and the Teamsters, the Teamsters finally honored their commitments. The UFW finally gained official jurisdiction over the organization of the farmworkers. In return Chavez's union dismissed its lawsuits against the Teamsters, and acknowledged Teamster jurisdiction of canneries, food plants, and producer markets. The end of the conflict allowed the UFW to focus on battling the growers, and to focus on properly expanding the union. As a result, by the end of the following year more than 100,000 farmworkers had joined Chavez's ranks. The UFW had finally come into its own. ${ }^{33}$

\section{The Bishops' Ad Hoc Committee and Higgins: Mediation of Temporal Matters}

George Higgins's actions as a participant of the Bishops' Ad Hoc Committee, and its efforts to mediate between the growers and farmworkers of California, were often interpreted as partisan to Chavez and the UFW. Even though many grape growers were on the record supporting Higgins's and the Committee's role in mediation, the entry of the Teamsters into the conflict altered this dynamic. Surprisingly, the most critical accusations came from fellow clergy

\footnotetext{
${ }^{32}$ Ibid., $124-128$.

${ }^{33}$ Ibid., $128-129$.
} 
who first supported the growers, and then later, the Teamsters. Editorials by papers like Twin Circle, a conservative national weekly, demonstrated such. Its editor-in-chief, Father Daniel Lyons, S.J., portrayed Higgins as a co-conspirator of Chavez who helped hijack the national hierarchy to serve their own purposes. Higgins was described as "the dynamo behind the bishops' committee," a priest who had "spent his life crusading for compulsory unionism." Such an effort explained the reasons why "he and his committee of one or two active bishops talk with the union [the UFWOC] as though it represents the workers, instead of trying to understand the thinking of the workers themselves. They have determined that compulsory unionism is what should be imposed on the workers, whether the workers like it or not, and whether the workers want this particular union or not. When the bishops' committee talks about 'negotiations' they mean compulsory unionism and nothing else."34

Lyons's assessment of Higgins appears to be due in large part to Higgins's support of the boycott in 1968, where Higgins argued that the farmworkers, along with any other worker, held an intrinsic right to organize and bargain collectively. Since the growers refused to recognize these rights, the boycott by the UFWOC was valid, a charge substantiated by Higgins's predecessor, John A. Ryan. Citing Monsignor Ryan and his position on the boycott as his primary example, Higgins argued that Ryan "took the position that a boycott is legitimate "when the injustice inflicted by the employer is grave, and when no milder method will be effective." If the worker did not have such recourse, then such a disadvantage suggested that employers had the "“right to pursue his advantage in an unreasonable way, and immune from reasonable interference." Such a system would be grossly unjust, and so it stood to reason that workers were "“endowed with the same right of seeking material benefits on reasonable conditions and by

\footnotetext{
${ }^{34}$ Daniel Lyons, "Father Lyons Views the News," Twin Circle, July 12, 1970, ACUA/GGH Papers, Box 222, Folder 13.
} 
reasonable methods," as that of their employers, and in the instance where an employer's actions were gravely unjust, the boycott then was " a reasonable method" in response.

Consequently, since Higgins believed that the farmworkers had no other recourse in the conflict, the boycott was both a viable and just method to force recognition of these rights by the growers. The refusal of the growers to acknowledge the basic right of organization was such that the farmworkers had no other option. It was for this reason that Higgins believed the California grape boycott met Ryan's conditions, and was “a perfect case in point.” In light of this, he endorsed the actions of the union and hoped that it would "soon achieve its one and only purpose, namely, to persuade the growers, at long last, to recognize their workers' right to organize." 35

In fairness to Higgins, his assertion of the right to organize as a basic human right did not touch on whether or not workers should unionize, but rather that they held the right to do so, should they choose to do so. The compulsory aspect of Lyons's argument was not applicable in this regard, for Higgins believed that the farmworkers wished to organize and to be recognized as a union. The purpose of the boycott was to secure this recognition and "compel the growers to bargain collectively with the union." Unfortunately for the UFWOC, the growers were "not required by law to recognize [the] UFWOC even if a majority of their employees" desired a union. There wasn't any leverage to force the growers to the bargaining table, so the growers simply "refused to give in to their demands." ${ }^{36}$ Consequently, the union had no other option than the boycott. This and the strike were the only forms of leverage that the union could muster, and Higgins supported them in this regard.

\footnotetext{
${ }^{35}$ George Higgins, "The Grape Boycott and the Right To Organize," The Yardstick, Jan. 6, 1969, ACUA/GGH Papers, Box 373, Folder 3.

${ }^{36}$ George G. Higgins, "Deprecates Attack on Cesar Chavez," The Yardstick, Sept. 16, 1968, ACUA/GGH Papers, Box 373, Folder 2.
} 
The social teachings of the Church backed Higgins's support of the farmworkers and their goal of economic self-determination. As an expert in the social teachings of the Church, Higgins knew that Rerum Novarum supported the rights of the workers to strike and organize, especially since the workers' relationship with his employer was one that reflected his or her dignity as a person. The relationship, as a reflection of human dignity, was a moral issue that fell under the Church's authority. In this same respect, the encyclical lauded Catholics who fought for the betterment of the working class, and gave its blessing to the associations they created. These organizations served to protect the individual worker, as well as his or her dignity, by negotiating contracts on their behalf. Without such organizations, the worker was subject to the conditions of a free market where "through necessity or fear of a worse evil the workman [had to] accept harder conditions because an employer or contractor [would] afford him no better," and so became the "victim of force and injustice." 37 In this same respect, Higgins also knew how Quadragesimo Anno developed the principles of Rerum Novarum, and applied them to a more modern age. Quadragesimo Anno advocated a new social order based upon the principle of subsidiarity, which served as the basis for the Industry Council Plan Higgins had promoted over the past 15 years. Unions played an important role in the creation of such an order, particularly through their use of collective bargaining. The principle of subsidiarity recognized the rights of both individuals and associations to accomplish what they may through their own initiative and industry, and charged that it was an "injustice and at the same time a grave evil and disturbance of right order to assign to a greater and higher association what lesser and subordinate

\footnotetext{
${ }^{37}$ Pope Leo XIII, “Rerum Novarum: Encyclical of Pope Leo XIII on Capital and Labor," The Holy See, http://www.vatican.va/holy_father/leo_xiii/encyclicals/documents/hf_l-xiii_enc_15051891_rerum-novarum_en.html (accessed on 10.25.2013).
} 
organizations can do. ${ }^{38}$ However, neither did it disqualify the right - nor the authority - of higher associations to involve themselves in matters of these lesser associations, which for Higgins' purposes was the relation of government to industry and labor. Consequently, such a system required workers, employers, and the government to cooperate with one another in economic matters. He also recognized that Mater et Magistra released the Church from the strictures that Quadragesimo Anno's promotion of the Industry Council Plan had created. Instead, Mater et Magistra sought to advance the same principles of cooperation independent of the plan itself, allowing the faithful to develop programs which best suited the realization of the principles set forth by the prior social encyclicals. Perhaps more importantly, Pope John XXIII's encyclical presented a religious view of the lay apostolate which encouraged the harmonization of their temporal and spiritual vocations. The laity was now called to Christianize the world through their temporal efforts, which included the social influence of secular unions. All of these principles were summed up by the Second Vatican Council's Constitution of the Church in the Modern World.

Higgins was not the lone member of the Ad Hoc Committee who supported the teachings of the Church on trade unionism and collective bargaining either. The chairman of the Committee, Bishop Donnelly, was of like mind with Higgins on this very issue. Of particular importance to both Higgins and Donnelly was the Constitution's declaration that:

Among the basic rights of the human person is to be numbered the right of freely founding unions for working people. These should be able truly to represent them and to contribute to the organizing of economic life in the right way. Included is the right of freely taking part in the activity of these unions without risk of reprisal. Through this orderly participation joined to progressive economic and social formation, all will grow day by day in the awareness of their

\footnotetext{
${ }^{38}$ Pius XI, Quadragesimo Anno, as cited in George G. Higgins, The Yardstick, "The Industry Council Program," November 18, 1946, ACUA/GGH Papers, Box 343, Folder 12.
} 
own function and responsibility, and thus they will be brought to feel that they are comrades in the whole task of economic development and in the attainment of the universal common good according to their capacities and aptitudes.

When, however, socio-economic disputes arise, efforts must be made to come to a peaceful settlement. Although recourse must always be had first to a sincere dialogue between the parties, the strike, nevertheless, can remain in present-day circumstances a necessary, though ultimate, means for the defense of the workers' own rights and the fulfillment of their just desires. As soon as possible, however, ways should be sought to resume negotiations and discussions towards reconciliation. ${ }^{39}$

Furthermore, Donnelly was not the only bishop on the Committee who agreed with Higgins on this issue. Bishops Manning and Donohoe were on the record in favor of the rights of trade unionism and collective bargaining as well. Both made public statements on the farmworkers' struggle, and their right to organize and bargain collectively well before the creation of the Committee. Donohoe had issued a public statement supporting the farmworkers' right to organize and bargain collectively as early as 1966, while Manning made a similar statement two years later on behalf of the California bishops in $1968 .^{40}$

The Bishops' Ad Hoc Committee was not alone in supporting the right to organize and bargain collectively either. The hierarchy backed them in this regard, made clear by their statements on farm labor from both 1968 and 1969. Consequently, Higgins and the other members of the Ad Hoc Committee assumed their stance on these issues was without question, that Church teaching allowed no other stance by the American Church, let alone the Committee. If the growers recognized such rights, then the Committee could be at service to both parties in their attempt to work out an agreement. However, if the growers did not recognize this basic

\footnotetext{
${ }^{39}$ George G. Higgins to Most Rev. Joseph F. Donnelly, July 10, 1970, ACUA/GGH Papers, Box 210, Folder 19; This correspondence contains Higgins answers to a set list of interview questions provided by Gerry Sherry for Bishop Donnelly, the chairman of the Bishops' Ad Hoc Committee.

${ }^{40}$ Prouty, "Cesar Chavez and the Catholic Civil War," 117.
} 
right, there was no point in mediating at all. It was for these reasons that Higgins could confidently argue that the Committee's

role, contrary to certain statements made by critics of the Committee, was not an adversary role. We did not go into California to beat the drums for Cesar Chavez and the farm workers, nor did we go there in any way to oppose the growers. We offered our services to be of whatever assistance we could be and I think were of some assistance to help the parties to come together around the negotiating table and hammer out contracts. This [was] not to say, however, that we were completely neutral.... [due to] the social principles involved. ${ }^{41}$

These social principles were "labor's right to organize and bargain collectively," which Higgins considered to be the "crucial issue involved" in the farmworker struggle. All members of the Committee recognized these rights as the basic issue of the conflict. The right of the worker to organize and bargain collectively had to be recognized in order for progress to be made, and for resolution of the conflict to be reached. It was so basic that it seemed to Higgins that "no one who speaks from the social traditions of the churches can pretend or should pretend to be neutral," when it came to this right, and that America as a nation was " 35 to 40 years late in enabling farm workers to exercise that right, a right which in most other areas of American economic life has long since been accepted.."${ }^{42}$

Complementing this stance, Higgins also acknowledged the plight of agribusiness in California, especially that of the small farmers. Echoing back to the 1969 Statement on Farm Labor, Higgins conceded that farmers also faced hardship and uncertainty as agribusiness owners. Higgins admitted that anyone "with any acquaintance, even as an outsider, with the Agricultural Industry, must be aware of the fact that there are problems peculiar to this Industry

\footnotetext{
${ }^{41}$ George G. Higgins, "Remarks of Monsignor George G. Higgins to the Clergy Conference" (address presented in Phoenix, Arizona, June 21, 1972), ACUA/GGH Papers, Box 330, Folder 4, 2 - 3.

${ }^{42}$ Ibid., 3.
} 
and especially for the small growers." These problems did not entitle the land owner to solve them at the expense of the field worker, however. Rather, the principles of class cooperation expressed in the Industry Council Plan of Quadragesimo Anno, and reiterated in Mater et Magistra, provided the solution to the issues at hand. In order to bring about such cooperation, the practice of collective bargaining remained paramount. Higgins believed that the "sooner the two [could] sit down together and begin to bargain and hammer out contracts... the sooner they [would] be able then to address themselves jointly to the problems of the Industry which [were] common to them both." The dialogue that took place during the process of collective bargaining would reveal these common causes between the two parties, for many "of the problems that the growers think of as being their problems [were] also the problems of the workers," who also had to accommodate "the seasonal character of the Industry." ${ }^{43}$ As it stood, Higgins believed the experience of the Ad Hoc Committee illustrated that there was "no possible solution to the farm labor problem ... until labor and management sit down and negotiate contracts." ${ }^{, 4}$ Ultimately, the purpose of the Committee was to facilitate such an exchange, and so they offered their services as mediators.

\section{The Role of Mediation: To Preserve Communication}

Higgins and his fellow Committee members sought to provide a mediating force to the conflict that existed between the growers and the fieldworkers, but their services depended solely upon the invitation of both parties involved in the dispute. This request for mediation was essential, for by inviting the Committee to mediate, the growers implicitly recognized the rights

\footnotetext{
${ }^{43}$ Ibid., 4.

${ }^{44}$ Ibid., 6.
} 
of the workers to organize and bargain collectively. Besides this recognition, the invitation to mediate also acknowledged the validity of the UFWOC as a union, and its right to bargain on behalf of its members. In turn, recognition of the UFWOC by the growers demonstrated some level of respect for Chavez and his union, a respect that had been won through years of strikes and boycotts.

Higgins understood that in order to mediate effectively between the growers and the UFWOC, respect between the two parties had to be maintained. Character attacks had to be addressed and resolved immediately, since they threatened to disrupt open communication between both parties. Higgins publicly defended the UFWOC against the charges that it was merely a social and/or religious movement for this very reason. This distinction was rather important, for it spoke to the validity of the UFWOC and its place at the bargaining table with the growers, as well as its place within the larger American labor movement. Unfortunately for Higgins and the Ad Hoc Committee, the defense of the UFWOC along these lines fostered accusations of partisanship against Higgins and the Committee. These accusations continued throughout the Ad Hoc Committee's efforts to mediate between the growers and the farmworkers, as well as that of the Teamsters.

Higgins's first public recognition of Chavez took place in the pages of the Yardstick in April of 1966. Chavez and the NFWA had just secured a contract with Schenley Industries, the second largest grape growing firm of Dern County, California, and had become the sole bargaining agent for the workers of that company. While this was a major victory for Chavez, Higgins placed it within a national context, arguing that "a victory for the union in California will mean eventual victory on farms elsewhere in the United States.” From Higgins's perspective, the organization of agriculture had finally begun. The question of how Chavez 
succeeded where others failed remained, however. Certainly, the efforts of organized religion on Chavez's behalf helped the union in its struggle to gain recognition by the growers. However, Higgins placed more faith in the influence Chavez held as an organizer. Agreeing with reporter Dick Meister of the Herald Tribune, Higgins acknowledged that it was Chavez who helped the farmworkers learn "what outside union organizers had never been able to teach them. They learned the lesson of unity, and they practiced it daily in the affairs of their own association," particularly through the credit union Chavez had established for their benefit. The credit union was the integral step, for it showed the workers that "by banding together, they could pool their resources and buy the things they needed at discount prices." After learning such a lesson, it was only a matter of time before the workers applied what they had learned to their work in the fields. Thus, while the support of religious and civil groups was beneficial to the movement, Higgins believed it was "Chavez who made the essential difference." For his hard work, Higgins endorsed Chavez, stating, “More power to him. We haven’t seen anyone like him in the American labor movement in many a long day." 45

As evidenced by his first column on Chavez in the Yardstick, Higgins believed from the start that the farmworkers of Delano had voluntarily come together to form the NFWA, and that Chavez genuinely represented the farmworkers' interests. ${ }^{46}$ The influence and support of various religious organizations, while helpful, did not change the fact that the success of the NFWA rested upon its genuine labor roots. This belief remained a constant for Higgins throughout his relationship with Chavez and the union. Complementing Higgins's belief was the religiosity of the movement, especially Chavez's use of Catholic imagery and liturgical practice, as a means to

\footnotetext{
${ }^{45}$ George G. Higgins, “Cesar Chavez: 'New Breed' Labor Leader?” The Yardstick, April 18, 1966, ACUA/GGH Papers, Box 373, Folder 2.

${ }^{46}$ The NFWA was the predecessor to the UFWOC, which later became the United Farm Workers of America, AFLCIO (UFW).
} 
promote the unity of the farmworkers. Higgins understood that such an adaptation by Chavez not only benefited the NFWA, but also benefitted the labor movement as a whole. In the eyes of Higgins, it mirrored the liturgical theology meant to solve the apathy that characterized labor's rank-and-file throughout the 1960s. For Higgins, the return of such religious identity to the labor movement was providential, and was a credit to Chavez. Anyone who attempted to use Chavez's religious belief as a means to discredit the union, either did not understand the place of religion within the broader labor movement, or sought to attack the movement itself.

Consequently, the UFWOC's rallying cry of "La Causa" represented the rank and file in step with one another and its leadership. This explains Higgins's strong support of Ronald B. Taylor's book on Chavez, titled Chavez and the Farm Workers. Taylor acknowledged that Chavez's work incorporated elements of both a trade union and a social movement, but that for Chavez and his union, there was no separation of the two. It was for this reason that Higgins believed Taylor's book was “required reading for those traditional labor leaders ... who, try as they will, cannot seem to understand what makes Chavez and his movement tick."47 The acknowledgement of this blend of social movement and trade unionism was so important that Higgins "made a private vow never again to discuss the farm labor controversy with anyone, on either side of the fence, who hasn't read it cover to cover." 48

In his account of Chavez and the union, Taylor examines Chavez's religious background, and how it served as the genesis of his interest in social justice. Father Donald McDonnell, a priest from San Jose who had organized a mission for the farmworkers through the archdiocese of San Francisco, was particularly influential in this regard. It was during his ministry to the rural

\footnotetext{
${ }^{47}$ Ibid.

${ }^{48}$ George G. Higgins, “'La Causa': the Rank and File in Step,” America, July 5, 1975, 11 (ACUA/GGH Papers, Box 240, Folder 7).
} 
poor that McDonnell met Chavez, and the two became friends. The friendship was mutually beneficial, for Chavez aided McDonnell in his ministry, and at the same time learned all that he could about the social teaching of the Church. In particular, Chavez sought to apply this knowledge in relation to labor organization, which was the start of his understanding of the labor movement as a religious movement. ${ }^{49}$ Through the influence of McDonnell, Catholicism became a part of Chavez's labor identity. This identity explained why the Mass, the fasts, the marches, and the visible presence of the Lady of Guadalupe were integral to the farmworker movement. All of these religious elements served to unify the people, and reminded them of the unity they shared through their mutual suffering. ${ }^{50}$

A prime example of this Catholic labor identity may be seen through Chavez's march to Sacramento, which took place in March of 1966. Chavez, along with 75 members of the union, led a Lenten pilgrimage which started in Delano and ended in Sacramento on Easter Sunday. Along the 300 mile route, the union members displayed a statue of the Virgin of Guadalupe, sang union and worker songs, and held rallies at the end of each day. Each morning Chavez and his supporters attended Mass to prepare themselves. Each evening more and more farmworkers came out of the fields to attend Chavez's meetings, where he spoke to them of their economic needs. More often than not, these workers would join Chavez's march for days at a time. William Kircher, the Director of Organization for the AFL-CIO, participated in the march as well, and soon recognized it as an incredible organizational tool. Kircher believed that if Chavez had taken the approach of the modern labor organizer, he would have failed in his enterprise. The farmworkers "had no frame of reference" for the American labor movement, for "they were people who had been born in Mexico and had lived most of their lives working in Mexico and

\footnotetext{
${ }^{49}$ Ronald B. Taylor, Chavez and the Farmworkers, (Boston: Beacon Press, 1975), 81.

${ }^{50}$ Ibid., 223.
} 
the United States." Chavez understood this. Consequently, when he "directed their attention to the economic needs [of the community], he [also] pulled them together through this common denominator, the cultural religious form. ${ }^{, 51}$ For Chavez and the farmworkers, their religious identity was a part of their identity as a union.

Chavez's incorporation of his religious identity fell directly in line with Higgins's promotion of the liturgy as a remedy for the apathy present within the greater labor movement. In their own way, Chavez and the members of the UFWOC lived the liturgical theology that Higgins had promoted ten years prior. Chavez and his union understood the importance of "the Mystical Body, the corporate Christ," for it was through "the liturgy and especially the Mass" that Chavez organized the farmworkers. Chavez realized that the individual who was "present at Mass [was] a member of the group - acting, giving, receiving, worshipping together with his fellow Catholics." It was through this medium that Chavez and the UFWOC encouraged a "sense of fellowship of all in relation to all," which had to "be carried into the political order where a man's individual contribution is more important than he thinks it is. " ${ }^{52}$ Higgins realized that for Chavez and the members of the UFWOC, there was no division between their temporal and spiritual lives. By incorporating the pilgrimage, the fasting, the celebration of the Mass, and the imagery of the Virgin Mary, Chavez was merely following what the social encyclicals of John XXIII had promoted. He was Christianizing the social institution that was the union.

Consequently, Higgins would not have interpreted Chavez's use of liturgical elements as a strike against whether or not the UFWOC truly constituted a union. Instead, he would have interpreted such elements as a validation of it.

\footnotetext{
51 Taylor, Chavez and the Farmworkers, 169.

${ }^{52}$ George G. Higgins, "The Mass and the Political Order" (address presented at the $16^{\text {th }}$ National Liturgical Week in Worcester, MA, Aug. 24, 1955), ACUA/GGH Papers, Box 324, Folder 4, 135.
} 
This was the primary reason why Higgins was much "more concerned about [Twin Circle's] repeated attempts to undermine Chavez's reputation and to cast doubt on his personal integrity as a labor leader and a Catholic layman.. ${ }^{, 53}$ From his perspective, the personal attacks by Twin Circle, as well as those of its allies, were attacks on the labor movement and its right to organize and bargain collectively. A primary example of such an attack was that of "Little Cesar," written by the Washington-based reporter, Ralph De Toledano. Higgins immediately noted its publication by Anthem Books, which he asserted was "a poorly camouflaged front for and a wholly owned subsidiary of the National Right to Work Committee.” As a direct consequence, the purpose of Toledano's work was immediately suspect, and explained why the book was filled with "half-truths, sly innuendoes, irresponsible gossip, and outright inaccuracies." It seemed obvious that Toledano never intended to present "objective criticism of Chavez and the UFWOC," but rather sought "to persuade his readers, by dint of sheer repetition, that not only the closed shop but the union shop as well 'runs directly counter to the First, Fifth and Ninth Amendments to the Constitution." ${ }^{\text {54 }}$ Consequently, Toledano's true target was the labor movement and its support of the union shop. The book, "written as it was under the auspices of the National Right to Work Committee," was "an attack not only on Chavez and the United Farm Workers Organizing Committee, but also on AFL-CIO President George Meany and the officers of all the major independent unions. ${ }^{, 55}$ Making matters worse, the hatchet jobs against Chavez only served to prolong the conflict. Higgins was quite clear in this regard, arguing that for as long as

\footnotetext{
${ }^{53}$ George G. Higgins, "The Grape Boycott and the Right to Organize," The Yardstick, Jan. 6, 1969, ACUA/GGH Papers, Box 373, Folder 6.

${ }^{54}$ George G. Higgins, "Ralph De Toledano on Cesar Chavez," The Yardstick, April 12, 1971, ACUA/GGH Papers, Box 368, Folder 17.

${ }^{55}$ George G. Higgins, “De Toledano versus Chavez, Part II,” The Yardstick, April 19, 1971, ACUA/GGH Papers, Box 368, Folder 17.
} 
Chavez and his union are being attacked as communist agitators, etc., and so long as growers organizations go around passing out free copies of Ralph de Toledano's vicious book on Chavez, 'Little Cesar,' and similar books and pamphlets there is no possibility of settling the dispute. It creates a terribly bad atmosphere and delays the solution to a very serious problem - that solution being bona fide collective bargaining. ${ }^{56}$

The main issue of these attacks was that they sought to derail the mediation efforts of the Bishops' Ad Hoc Committee, and by doing so prevent the recognition of the UFWOC as a valid union by the growers. Every time the Ad Hoc Committee facilitated the signing of a contract, it reinforced the perception of the UFWOC as such. As a mediator, Higgins was conscious of his role to facilitate dialogue and compromise between the parties involved. He did not consider himself, or his fellow Committee members, as advocates of either party of the dispute, whether that was the growers or Chavez and the UFWOC. Certainly, he respected Chavez as a true labor leader, but at the same time he acknowledged that Chavez had "his faults and imperfections and [was] certainly open to objective criticism. ${ }^{, 57}$ There is little doubt that such criticism would have taken place in the collective bargaining sessions between the growers and the UFWOC. ${ }^{58}$ In terms of the Delano conflict, if Higgins and his fellow Committee members had been deemed partisan, than it was unlikely that any grower would have requested their services. This was

\footnotetext{
${ }^{56}$ George G. Higgins, "Solving the Farm Labor Crisis Through Collective Bargaining," The Yardstick, August 14, 1972, ACUA/GGH Papers, Box 373, Folder 4.

${ }^{57}$ George G. Higgins, “De Toledano versus Chavez, Part II,” The Yardstick, April 19, 1971, ACUA/GGH Papers, Box 368, Folder 17.

${ }^{58}$ Incidentally, neither was Higgins unwilling to criticize Cesar himself. While attending the Conference on a National Migrant Ministry, in Atlanta, January $6^{\text {th }}$ and $7^{\text {th }}, 1971$, Higgins expressed his disappointment over Chavez's speech at the opening of the Conference. Chavez had "made it abundantly clear that what he wants is a national organization of religious leaders who will support UFWOC 1000 per cent with staff and funds and will do so without asking any questions or offering any advice." Furthermore, in Higgins "judgment, he appealed very crassly to the guilt feeling which so many Protestant social actionists seem to harbor in their souls and even went so far as to threaten them with the enmity of the poor (meaning, in this case, farm workers) if the religious community fails to measure up to his expectations. All in all," Higgins "thought it was a miserable performance on" the part of Chavez (Higgins to John Cosgrove, January 15, 1971, ACUA/GGH Papers, Box 236 Folder 1).
} 
certainly not the case, for the Bishops' Ad Hoc Committee mediated the vast majority of the contracts for that region. It was only when the Teamsters became involved in the conflict that the mediation services of the Committee broke down.

Prior to the entry of the Teamsters, the representation of the farmworkers by the UFWOC had never been questioned. By signing the contracts with the Salinas lettuce growers, the Teamsters changed this dynamic. The Teamster contracts allowed the growers to claim that the farmworkers had organized and bargained collectively. As a result, the growers did not see any need for the involvement of the Committee. No mediation was necessary, at least on their end. Any mediation which did occur now took place between the two unions in an effort to end a jurisdictional dispute. Unfortunately for the Committee, the mediation efforts to resolve the dispute between the UFWOC and the Teamsters were not easy, to say the least. Each and every time the Committee worked out a resolution, the Teamsters inevitably broke the newly formed contract. As a result, Higgins and his fellow Committee members began to see the actions of the Teamsters in a different light. The conflict between the Teamsters and the UFWOC was not so much a jurisdictional dispute between unions, as it was a case of collusion between the Teamsters and the growers.

The Teamsters had never intended to resolve the conflict, but instead had utilized the good will and efforts of the Committee to serve their own ends, as well as that of the growers. To make matters worse, Fitzsimmons' union had joined the growers in their battle against the farmworkers and the UFWOC. By signing the contracts with the growers without consulting the farmworkers, the Teamsters had joined with the growers in refusing to recognize the basic rights of the farmworkers. Assuredly, the farmworkers now had contracts and representation, but they had never asked for Teamster representation. Instead, it had been foisted on them by the growers 
and the Teamsters. As a result, the Teamsters could not claim to honestly represent their interests. Rather, they were merely claiming to represent those who did not want their representation. Once again the farmworkers were fighting for the right of economic selfdetermination.

\section{The Teamster Betrayal and the Reassertion of the Workers' Rights}

After their experience mediating the contracts between the UFWOC and the Delano growers, the Committee believed there was "no question that the farm workers want[ed] union recognition." Given that the UFWOC was the only union attempting to negotiate with growers at the time, and that Chavez had invested so much in his efforts to organize the farmworkers, no one questioned whether the farmworkers wanted the UFWOC to represent their interests. The Teamsters' entry into the conflict challenged this understanding, however, and the Committee acknowledged it early on in the jurisdictional dispute. For Donnelly and his fellow Committee members, the "only question" that the dispute presented was "which union [did] the workers want." It was an important question to answer, for if they were "to safeguard the newly-won peace in the agricultural industry, and to avoid the possibility of another prolonged struggle," then all the parties of the conflict had to "come together to seek a resolution of this problem."59

The Committee believed it had found the answer to that very question when the Teamsters and the UFWOC recommitted to their 1967 jurisdictional pact on August 12, 1970. For all intents and purposes, the Teamsters had recognized the UFWOC as the farmworkers'

\footnotetext{
${ }^{59}$ George G. Higgins, "Statement By Msgr. George G. Higgins, U.S. Catholic Conference, Washington, D.C. in the name of the U.S. Catholic Bishops' Committee on Farm Labor" (statement by Higgins, August 12, 1970), ACUA/GGH Papers, Box 222, Folder 2, 1.
} 
representatives. Unfortunately, the Teamsters did not honor this agreement mediated by the Committee, and as the days, weeks, and months passed new information concerning the actions of the Teamsters came to light. The lettuce growers had invited the Teamsters, and had signed "sweetheart deals" with the union in order to keep Chavez and the UFWOC out of the fields of Salinas. As Higgins described it, it was all "done very quietly." 60 These deals favored the growers, and protected one of the most hated practices that the growers employed - the use of a labor contractor. Labor contractors were the middlemen of farm labor; they supplied the farmers with day laborers to harvest their fields, and at the same time facilitated employment of the farm workers. Besides securing employment for both the growers and the workers, the contractors transported the workers to the job site. In return for their services, contractors collected payment from the workers, and after deducting a fee, paid the workers for their labors. Unfortunately, the system was rife with corruption. Many contractors took advantage of this practice to gouge the workers of their pay, misrepresenting the payment of the farmer to their advantage. Making matters worse, there was little the farm worker could do to challenge the system. Since contractors chose the laborers for the job at hand, they decided which farm workers to employ. This decision was based solely on the whim and discretion of the contractor, and often involved the input of the farmer. Workers who complained could easily be marginalized, for the contractors and farmers simply blacklisted any worker who opposed them. Transportation complicated the issue as well, for if the workers unified in their opposition to the contractor, the

\footnotetext{
${ }^{60}$ George G. Higgins, "Address to the Priests of the Archdiocese of Los Angeles" (address presented for the clergy of the Archdiocese of Los Angeles, Mount Saint Mary's College, Los Angeles, CA, Jan. 29, 1971), ACUA/GGH Papers, Box 329, Folder 6, 4.
} 
contractor simply sought out different workers from a different geographical location, and transported those workers to the fields. ${ }^{61}$

Chavez understood very quickly that such a system undercut the strength of the union, and moved to institute a different system - the hiring hall. Under the hiring hall system, farmers notified the hall two-weeks in advance of their intent to harvest, and requested the number of workers they needed for the job at hand. In turn, the hiring hall notified the workers of the job, and allocated those jobs according to the seniority of its members. Once senior members had taken advantage of the openings, the hall would open the remaining jobs to the remainder of the hall's work force. By removing the contractor, Chavez provided a system where workers were rewarded for their seniority and their reliability, and placed more earnings in the hands of the workers by removing the service fee of the contractors. Furthermore, the hiring hall tied the employment of the workers to a set geographical location. Finally, and more importantly for the union, the hiring hall prevented the growers from controlling the work force, and arbitrarily deciding which workers they wanted on their fields. ${ }^{62}$

The Teamster contracts allowed "growers to bring back the labor contractors who handpick groups of workers for a day's labor," a move that Higgins believed "was the determining factor in their [the growers'] decision to break away from the UFWU and settle with the Teamsters." Higgins had every reason to believe this was the case, for the grape growers had "held out against the hiring hall system until the bitter end, but finally had to agree to it as the price of getting a settlement." Chavez, for his own "part, [was] still fiercely committed to doing away with the labor contracting set-up and replacing it with the hiring hall," and considered it "a

\footnotetext{
${ }^{61}$ Taylor, Chavez and the Farmworkers, 16 - 20.

${ }^{62}$ Ibid.
} 
non-negotiable issue." ${ }^{\prime 63}$ The Salinas lettuce growers surely knew this, and anticipating the UFWOC's organization and representation of their workers, decided to seek different union representation in order to protect their interests. Moreover, the fact that the Teamsters retained the services of the labor contractors, and even "signed a master agreement" with them, contributed to Higgins's belief that the farmworkers never wanted Teamster representation, and that the Teamsters did not truly represent the farmworkers' interests. The fact that Chavez fought against this practice demonstrated that he and the UFWOC did represent them. As Higgins understood it, Chavez "and his members know from bitter experience that the labor contracting system has always operated at the expense of the workers. They hate the system with a passion born of personal suffering and are determined to do away with it once and for all."64

By returning to the practice of labor-contracting, the Teamsters only affirmed that they did not represent the farmworkers' interests, and that the farmworkers did not want their representation. As a consequence, when it was discovered that the farmworkers had never even been consulted during the course of the Teamsters' negotiations with the lettuce growers, the revelation likely did not surprise Higgins. The seizure of the grape contracts in April of 1973 certainly did, however. It was an act that Higgins described as a "flagrant violation of trade union ethics;" one which would live in infamy as a part of the history of the American labor movement. ${ }^{65}$ Regardless of Higgins's feelings on the matter, the actions of the Teamsters forced the Committee's hand. The Committee had no choice but to resume the original stance they had defined during the course of the grape grower negotiations. The farm workers were still fighting for the "right to organize into a union of their own choosing," and "no other union and no group

\footnotetext{
${ }^{63}$ George G. Higgins, “The Farm Labor Dispute,” The Yardstick, May 7, 1973, ACUA/GGH Papers, Box 373, Folder 1 .

${ }^{64}$ Ibid.

${ }^{65}$ USCC News, "Msgr. Higgins Calls Teamsters' Act 'Shameful' Predicts Wide Support for Chavez, Workers," April 23, 1973, ACUA/GGH Papers, Box 241, Folder 5, 1.
} 
of growers should be permitted to interfere with the untrammeled exercise of this right." The growers and the Teamsters had disregarded the input and wishes of those they claimed to represent, and had "been doing just that since the Delano grape dispute was finally settled at the bargaining table in the summer of $1970 .{ }^{, 66}$ Once again, the farmworkers were being denied their basic right of economic self-determination, but this time it was at the hands of a fellow union. Consequently, this explains why the Committee felt it had no other means but to recommend the bishops support the UFW's boycott to force a resolution to the conflict. The bishops acted as the Committee recommended, and endorsed the UFW boycott of both grapes and lettuce in support of "the right of field workers to free secret ballot elections," which would "determine whether or not they want union representation and which union they want to represent them." ${ }^{, 67}$ Their support would persist until such elections had taken place.

\section{The Call for Free and Secret Ballot Elections}

While the Committee interpreted the actions of the growers and the Teamsters as denying the basic rights of the farmworkers, public perception of the issue was not necessarily the same. As one might expect, each party involved in the dispute claimed to represent the farmworkers and their interests, and argued to the public that the farmworkers supported their representation. To prove such claims, both the Teamsters and the UFWOC claimed to have won this representation through free elections. Given they had contracts with the Teamsters, the growers sided with them in their arguments. At the same time, both the Teamsters and the UFW accused

\footnotetext{
${ }^{66}$ George G. Higgins, “Address at the Farm Workers' Rally” (address presented at Farmworkers' Rally, Cleveland, Ohio, April 6, 1974), ACUA/GGH Papers, Box 331, Folder 2, 4.

${ }^{67}$ George G. Higgins, “American Bishops Consider the Farm Labor Problem,” The Yardstick, November 26, 1973, ACUA/GGH Papers, Box 368, Folder 16.
} 
each other of conducting sham elections, and opposing free and secret elections. The Teamsters even went so far as to claim that Higgins and the Ad Hoc Committee were party to these fraudulent elections on behalf of the UFW. This atmosphere contributed to the Committee's belief that free and secret elections were the only way to resolve the conflict, and served to validate their support of the UFW boycott until such elections occurred. Consequently, this led to their full support of the California Labor Relations Act in 1975, especially since its focus was to secure free, secret ballot elections in such a way that was agreeable to all parties.

The Committee had no doubts concerning Chavez and the UFWOC's claims, especially since it had conducted many of those elections on behalf of the growers and the union. The elections conducted by the Teamsters, however, were a different matter. A primary example of the Committee's misgivings was grower Kelvin K. Larson's election of 1974, where the farmworkers purportedly voted to switch unions from the UFW to the Teamsters. Higgins and the Committee believed Larson had conducted a valid election in 1970, after which he honored the results and signed a UFWOC contract. "All parties were consulted; all parties agreed to the rules and procedures; all parties agreed that a local Methodist minister, Rev. Lloyd Saatjian, should serve as supervisor of the election; all parties were allowed to have an official observer at the polls. The vote was $152-2$ in favor of the UFW." However, when Larson conducted another election in 1974, it "was decided unilaterally by Larson. The UFW was not notified that the election was even being held and was not present for the balloting or the ballot counting." Consequently, Higgins and his fellow Committee members believed the 1974 Larson election "was not a genuine election." 68

\footnotetext{
${ }^{68}$ George G. Higgins to Most Rev. Francis J. Furey, Archbishop of San Antonio, July 3, 1974, ACUA/GGH Papers, Box 241, Folder 5, 1.
} 
Larson was not the only grower employing such tactics. Other growers, particularly Gallo wineries, did very much the same. According to Higgins, Gallo and its cohorts made "much of the fact that the UFW's membership has dropped from more than 50,000 to approximately 10,000 ," and interpreted "this to mean that the workers have overwhelmingly rejected the UFW and have asked to be represented by the Teamsters." Higgins disagreed with this assessment, arguing that it was

a serious distortion of the record. The fact the UFW lost most of its contracts to the Teamsters in 1973 does not mean that the workers themselves have rejected the UFW. The fact is that they did not have an opportunity to express their preference. The record will show that no elections were held. The Teamsters and the growers simply got together and negotiated new contracts to replace the UFW contracts which had been in force since $1970 .{ }^{69}$

The truth of the matter was that "Gallo had a legitimate contract with the UFW," and when that contract expired, "Gallo, on its own initiative, walked away from the UFW and signed a contract with the Teamsters." According to Gallo, this move represented the wishes of the workers, because "the Teamsters produced cards showing that the majority of Gallo's workers wanted to be represented by the Teamsters." However, Higgins believed that "Gallo could have checked the validity of the Teamsters alleged representation cards by holding a supervised election," and "no such election was held. ${ }^{70}$ Once again, it appeared that while the growers and the Teamsters claimed to represent the farmworkers and that the farmworkers desired their representation, circumstances suggested otherwise.

The "elections" of the Teamsters allowed them to claim that the farmworkers did not want UFW representation, and by doing so clouded the answer that the Committee originally

\footnotetext{
${ }^{69}$ Ibid., 2.

${ }^{70}$ Ibid.
} 
hoped to settle during its 1970 jurisdictional mediation. The purported elections were not the only tactics the Teamsters and the growers used to further distort the issue, either. Besides claiming that elections demonstrated the farmworkers' desire for Teamsters representation, Fitzsimmons' union accused the UFW of rejecting legislation which supported secret elections. Taking out a full-page ad in the February $24^{\text {th }}, 1974$ issue of Detroit News, the local Teamsters accused Chavez of rejecting secret ballot election legislation, evidenced by his efforts to prevent any legislation that followed the National Labor Relations Act of 1935. Higgins rose to the UFW's defense, arguing that the Teamsters had presented a "complete distortion of the UFW's position with regard to secret ballot elections," and that the record of the UFW was "very clear on this issue." It showed "that prior to strikes and boycotts the union has consistently called for elections," but that "in the face of grower refusal even to talk about elections.... then the strike [served as] the election." In those circumstances where the strike had continued for some time, the UFW had consented to elections and conducted them according to NLRA regulations. The issue that the UFW had concerning implementation of NLRA legislation was that it either "outlawed the boycott or strikes at harvest; it provided for elections but not for good faith bargaining; it eliminated migrant and season workers from the right to vote; or it turned over the election process to groups hostile to the UFW." ${ }^{, 11}$ Such legislation would have gutted the effectiveness of the UFW, which Chavez could not allow - even though he supported the NLRA's measures in securing free, secret elections.

The Teamsters not only cast doubt on the stance of the UFW concerning elections, but also publicly questioned the Church's role as impartial observers at the elections the UFW had conducted. The Teamster president, Frank E. Fitzsimmons, and one of his local organizers,

\footnotetext{
${ }^{71}$ George G. Higgins, "California Farm Labor Dispute: The Teamsters," The Yardstick, March 18, 1974, ACUA/GGH Papers, Box 412, Folder 6.
} 
Antonio Mendez, made this abundantly clear in an interview conducted by the Today Show on July 16, 1974. Supporting their own cause, Mendez claimed that the Teamsters were not "by any means, ducking any elections whatsoever." Rather, they supported elections held "under the law of the land," which was the National Labor Relations Act. Continuing in this vein, he accused Chavez of calling for free elections, but then conducting elections which were anything but free. These elections were conducted by Church officials, who were there "to see whether the workers were workers or they weren't." Instead of serving to validate the election, however, their presence called it into question. Mendez believed that the clergy created an undue influence on the worker and their vote, and it was "just like having the workers say ... when he walks by that line to the election," that if he didn't "vote for Chavez, I'll go to hell.",72 Such a charge by the Teamsters would have been difficult to combat. It tapped into the religious aspects of Chavez's movement, but in such a way that it questioned the validity of the elections that the UFW conducted. Chavez had incorporated religious imagery and ritual as a part of the movement, and did so in conjunction with the clergy's support of the union's right to organize and bargain collectively. By calling this support into question, the Teamsters applied one of the UFW's greatest strengths against the union in the public arena.

Besides opening up such doubts to the public concerning elections conducted by Chavez under religious supervision, the Teamsters publicly questioned the integrity of the surveys conducted by the clergy as well. On April 10, 1973, Higgins took part in a survey of the fieldworkers to determine which union they preferred, and found that "approximately 85 percent of the 1,000 workers ... preferred to be represented by the United Farm Workers Union", while "less than 15 percent expressed a preference for the Teamsters." In response to those findings,

\footnotetext{
${ }^{72}$ Frank E. Fitzsimmons and Antonio Mendez, interview by Bill Monroe of the Today Show, July 16, 1974, ACUA/GGH Papers, Box 240, Folder 5, 2.
} 
William Grami, Director of Organization for Western Conference of Teamsters, argued that Higgins and his contemporaries had conducted a "phony poll," which had been taken "only among the people that were at the rallies that were being held in that area." The poll did not truly represent the farmworkers of the fields for those areas, and instead only served to prove that Higgins had conducted "a prejudiced poll.",73 Consequently, rather than proving Higgins's point that the farmworkers' preferred Chavez, the poll threw into question all efforts by Higgins, and by association, the Committee itself.

The actions of both the Teamsters and the growers only served to reaffirm the Committee's belief that free elections remained the only way to settle the dispute as to which union truly represented the farmworkers. Each side of the conflict had pitched their own story to the public, and it was painfully clear that mediation between the Teamsters and the UFW had no chance for success. Free elections would publicly determine the allegiance of the farmworkers, and do so in such a way that prevented allegations of deceit, invalidity, or theft. As the boycott progressed, Higgins and the Committee maintained that any legislation seeking to provide such elections had to concern elections alone. Any potential bills had to be "completely 'clean"” in this sense, meaning they could not contain any "anti-UFW sleeper clauses." They had to call "for supervised free elections - period." ${ }^{, 74}$ By arguing that legislation had to remain neutral, Higgins and the Committee helped keep the focus on free elections, and free elections alone. Neither the growers nor the Teamsters could object to this presentation, as it only asked them to publicly validate their assertion that the farmworkers wanted their representation.

\footnotetext{
${ }^{73}$ George G. Higgins, "Setting the Facts Straight," The Yardstick, July 2, 1973, ACUA/GGH Papers, Box 412, Folder 9.

${ }^{74}$ George G. Higgins, "California Farm Labor Dispute: The Teamsters,” March 18, 1974, ACUA/GGH Papers, Box 412, Folder 6.
} 
The California Labor Relations Act, passed on June 5, 1975, came very close in this regard. Personally sponsored and negotiated by the governor of California, Jerry Brown, the bill was "similar to the National Labor Relations Act, modified to reflect problems unique to agriculture.” In this sense, it was a compromise bill where each side gained and lost on certain positions they had held prior to its creation. First and foremost, it provided "for certification of a union only through secret ballot elections," but these elections could only "be filed when the employers' work force reflect[ed] at least 50 percent of peak seasonal employment." However, the bill also provided "for union certification within 48 hours if a majority of petitioning workers [were] on strike. Otherwise, the election would have to be held within seven days." Besides these conditions, the bill permitted "consumer boycotts but restrict[ed] the use of secondary boycotts in certain respects," and required "good faith bargaining by both management and labor, and prohibit[ed] unfair labor practices." As it was, the passage of the bill required that the UFW concede to some of the restrictions the NLRA would have required, but amended in such a way that made it palatable to Chavez and his union, as well as to the Teamsters and the growers. Higgins believed that the amendments to the bill were "entirely reasonable," and "strongly support[ed] the position taken by the California bishops in favor of the bill." While it did "not completely satisfy any or all of the parties involved in the farm labor dispute," it represented "a constructive step in the right direction." Such a development was "long overdue - a half century overdue." 75

For Higgins, the passage of the CALRA "marked an important turning point in the history of the United States," for it stood as the "first law ever enacted in any jurisdiction, federal or state," that guaranteed "farm workers the right to determine, by secret ballot elections, which

\footnotetext{
${ }^{75}$ George G. Higgins, "Farm Labor Legislation," The Yardstick, May 12, 1975, ACUA/GGH Papers, Box 373, Folder 2.
} 
union, if any, they want[ed] to represent them." ${ }^{, 76}$ Certainly the Committee had failed in its efforts to mediate the conflict between the Teamsters and the UFW, but while losing the battle of mediation between the UFW and the Teamsters, it had won the war. The original objective of Higgins and the Committee was met - farm workers had gained the right to organize and bargain collectively under the law. The growers of California could no longer refuse to acknowledge a union, and were obligated to recognize any union which the farm workers desired for representation. Besides this, the farm workers were also protected from having representation chosen for them. These rights were guaranteed, even when the growers attempted to defund the board which the CALRA had created.

Consequently, the actions of the Committee and the bishops following the creation of the CALRA were justified. In November of 1975, the bishops celebrated the passage of the act, and noting that secret ballot elections had both occurred and been guaranteed by law, ended its support of the UFW's boycott. From its perspective, the purpose of the Committee had been met. Furthermore, by helping to create the legal structures necessary to manage disputes between the growers and the farm workers, the Committee recognized that its place as a mediator in the conflict had passed. The role of mediator and arbitrator now fell to the board created by the CALRA, whose chairman was one of the Committee's own, the newly consecrated Bishop Roger Mahoney. As one might expect, his presence on the CALRB also complicated the Committee's involvement in future conflicts between the UFW, the growers, and the Teamsters. It is hard to imagine the Committee might have risked any further charges of partisanship by resuming a role on behalf of the UFW, particularly if such actions risked impugning Mahoney's impartiality as chairman. Besides these reservations, the Committee must have realized that any

\footnotetext{
${ }^{76}$ George G. Higgins, “Power Struggle Continues,” The Yardstick, February 16, 1976, ACUA/GGH Papers, Box 412, Folder 7.
} 
new conflicts between the parties would take place in the courts, rather than near the fields of Salinas and Delano. The Committee's time in California had largely come to a close, and so it waited in the hopes of future requests of mediation in other states.

Independent of his role as a member of the Committee, Higgins continued his support of the UFW in the California courts, but his time as a mediator of that conflict had passed as well. By the later 1970s he had also taken up a new cause - the unionization of Catholic schools and hospitals. Unfortunately, Higgins did not have much time remaining as a consultant for the United States Catholic Conference to work towards its implementation. Citing budgetary concerns, the bishops decided to retire Higgins early in October of 1978. Fortunately for Higgins, the decision of the bishops did not sit well with his contemporaries and supporters, and the bishops soon found themselves in a public relations nightmare. As a result, the bishops reversed their decision. The following chapter will conclude the dissertation with an investigation of the bishops' decision to retire Higgins, and the ensuing reversal by the bishops to allow him to remain until his mandatory retirement in 1980. 


\section{Chapter 9}

\section{The Retirement Scandal: The United States Catholic Conference of Bishops' Decision to Retire Higgins}

At the height of the Depression in the 1930s, Msgr. Ryan wrote:

'Effective labor unions are still by far the most powerful force in society for the protection of the laborer's rights and the improvement of his or her condition. No amount of employer benevolence, no diffusion of a sympathetic attitude on the part of the public, no increase of beneficial legislation can adequately supply for the lack of organization among the workers themselves.'

Some readers of 'The Yardstick' probably feel that I have emphasized this point too often during the past 56 years. I respectfully disagree, but there is no point saying exactly why now that I am retiring from the fray. My views on this issue are on the record, and it's too late to withdraw them.

- Rev. George G. Higgins, The Yardstick, September 10, 2001

$$
\phi
$$

On Oct. 13, 1978, the Religious News Service announced that the National Conference of Catholic Bishops' (NCCB) Committee on Research, Plans, and Programs (CRPP) had decided to retire George Higgins earlier than scheduled for budgetary reasons. The five Committee members, Bishop Thomas C. Kelly, O.P., the NCCB-USCC General Secretary; Joseph Bernardin, Archbishop of Cincinnati and former president of the NCCB-USCC; John R. Quinn, Archbishop of San Francisco and President of the NCCB-USCC, who served as the Committee's chairman; John Maguire, Coadjutor Archbishop of New York; and John R. Roach, Archbishop of St. Paul-Minneapolis and Vice-President of the NCCB-USCC, stated that the decision had been based on "a financial crunch caused by inflation," and that the move fell in line with other cuts the 
United States Catholic Conference (USCC) had made earlier in the month, among them being the closure of the Secretariat for Human Values. From a financial perspective, Higgins's early retirement, two years prior to the USCC's mandatory requirement at the age of 65, would have saved the Conference "some $\$ 45,000$ (including Msgr. Higgins' salary, secretarial costs, travel and office expenses).” In this sense, as Bishop Kelly argued to the News Service, the move to retire Higgins was “"strictly a financial consideration and there is absolutely no criticism of Msgr. Higgins' work involved."'1

The Committee was not the final arbiter, however. The decision had to be ratified by the body of bishops at their annual meeting in November, and fortunately for Higgins, his friends, coworkers and supporters were swift to voice their dissent over the Committee's decision. John Herling, the syndicated labor columnist of Herling's Labor Letter, argued that Higgins had "come to symbolize" the "Church's commitment to social justice not only in the abstract but in a wide range of social and ethical concerns," and that it was for this reason that no one believed the "poppycock" of the Committee's budget explanation. As a supporter of Higgins, he called upon the body of bishops to "rescind this ill-considered action." The Catholic lay journal Commonweal argued that the Committee had to have known that "for thousands of people, priests, religious and laity, his name has become synonymous with a strong church commitment to social justice," and hoped that the body of bishops would overrule the Committee come November. ${ }^{3}$ Fr. Andrew M. Greeley, the noted Catholic sociologist, columnist, and novelist, was much more direct in his criticism. Privately, he wrote both Archbishops

\footnotetext{
${ }^{1}$ Religious News Service, "Budget Cuts Results in Bishops' Agency Dropping Msgr. Higgins after 34 Years," Oct. 13, 1978, ACUA/GGH Papers, Box 429, Folder 8.

2 John Herling, “Astounding Stupidity,” John Herling's Labor Letter, Oct. 21, 1978, Vol. 28, No. 43, ACUA/GGH Papers, Box 429, Folder 8.

${ }^{3}$ Commonweal, "Getting the Ax," Oct. 27, 1978, ACUA/GGH Papers, Box 435, Folder 1.
} 
John Roach and John Quinn, acknowledging "that in the deliberations of the American hierarchy my opinion is of such trivial importance as to be hardly worth setting on paper," but since he was one of the few priests that could do so "without fear of reprisal," he had decided to "say what I think on l'affaire Higgins." His view, to say the least, was quite clear:

You and the other men responsible for this stupid action have disgraced and humiliated the Church. You are guilty of an injustice which cries to heaven for vengeance. You all should be ashamed of yourselves.

When the history books are written about this era, the Higgins dismissal is the one thing for which you will be remembered above all others. Catholics of the future will think even worse of you than we do today. As a mixture of ineptitude and cruelty your action is hard to match in the last two hundred years of Catholic life in America. ${ }^{4}$

Publicly, Greeley expressed his displeasure as well. He opined in his weekly columns that every "time I start feeling positive about the national hierarchy they come up with a new stupidity. The latest and the worst in a long time is their peremptory dismissal of Msgr. George Higgins after almost 35 years of service." Following up on this sentiment, Greeley argued that the "Higgins dismissal involves more than a violation of charity, more than a violation of justice; it is a violation of the solemn obligation of a bishop to provide intelligent leadership for the Church." Their decision was "an insult to those in the secular world who for years knew Higgins as the only man in the American Church who understood their problems," and their dismissal of Higgins suggested "that we need a program to preach the social action ethic to the leaders of the hierarchy." Such a

\footnotetext{
${ }^{4}$ Andrew M. Greeley to John Quinn, Nov. 1, 1978, ACUA/GGH Papers, Box 430, Folder 2; Andrew M. Greeley to John Roach, Nov. 1, 1978, ACUA/GGH Papers, Box 430, Folder 2.

${ }_{5}^{5}$ Andrew M. Greeley, "The Higgins Dismissal," The Long Island Catholic, Nov. 9, 1978, ACUA/GGH Papers, Box 429, Folder 8.
} 
program was obviously needed for the bishops "think you can preach social justice to others and ignore justice to your own staff; they think you can evangelize the world and not practice the principles of the gospel in dealing with your loyal, dedicated and brilliant employees." Consequently, Greeley called for anyone "who has ever worked in any parttime or consultative capacity, for the U.S. Catholic Conference/National Conference of Catholic Bishops (USCC/NCCB)" to "write ... to make clear that they will not serve again unless the bishops backpedal on George Higgins."

To his credit, Higgins's appeared to take his dismissal in stride. Writing to his friend, Ted Hesburgh, the President Emeritus of the University of Notre Dame, he confided that he was "not the least bit concerned about my personal status. Thanks to good friends like yourself, I feel confident that, come what may, I will be able to lead a useful life in the years, however few or many, that lie ahead." His only concern, rather, was the continuation of his work. "I would hate to see the work that I have been doing go down the drain, and, if I were to leave within the next twelve months, I am afraid that that might happen for the simple reason that, so far as I can see, nobody would be hired to take my place." ${ }^{8}$ If anything, Higgins felt sorry for Bishop Kelly and the Committee,

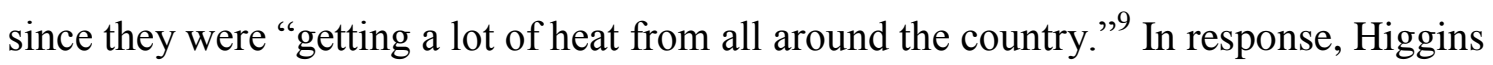
"tried to put the Executive Committee's decision in the best possible light" when giving interviews to the press, but knew his words were "falling on deaf ears." As a result,

\footnotetext{
${ }^{6}$ Andrew M. Greeley, “Column for Universal Press Syndicate," Oct. 28, 1978, ACUA/GGH Papers, Box 429 , Folder 8.

${ }^{7}$ Andre M. Greeley, "Cutting Higgins is Cruel, Dumb," Universal Bulletin, Nov. 10, 1978, ACUA/GGH Papers, Box 429, Folder 8.

${ }^{8}$ George Higgins to Ted Hesburgh, Oct. 12, 1978, ACUA/GGH Papers, Box 435, Folder 1; the actual letter from Higgins does not include Hesburgh's surname, but from the content of the letter, it is apparent that Hesburgh was the recipient.

${ }^{9}$ George Higgins to Joseph O’Brien, Oct. 18, 1978, UNDA/ACP Papers, Folder 14/27.
} 
"Kelly, Quinn, and the other members of the Committee are being bombarded with irate letters and phone calls from friends and associates of mine from all over the country," and Higgins believed there was "nothing more I can do to save face for the Committee."10

While Higgins hoped to blunt the criticism of the Committee in his interviews, this did not mean Higgins attempted to stop his supporters from taking up his cause, however. While public dissent was building over the Committee's decision, a behind-thescenes effort to save Higgins's place within the USCC formed soon after the announcement. John Joseph Egan, a fellow Chicago priest, friend of Higgins, and the founder of Notre Dame's Catholic Community on Urban Ministry, led the effort along with Nevila McCaig, Higgins's secretary of 27 years. ${ }^{11}$ Egan believed the decision by the Committee was a "grievous error" that demonstrated "somebody hadn't done their homework." ${ }^{12}$ This "homework" was the realization that the Higgins dismissal had greater implications for the social action movement. Writing Archbishop Joseph Bernardin, Egan argued that their decision was "a terribly stupid mistake," and that it had to "be redressed because the effects of your decision will seriously impede the work of social action and the relationship of the Roman Catholic Church with labor for years to come." For Egan, Higgins stood as a symbol of the social action movement, and his dismissal could not "be underestimated." Personally, he was shocked that Bernardin had not realized this prior to the Committee's decision, and he questioned how a person with

\footnotetext{
${ }^{10}$ George Higgins to Ernest J. Primeau, Oct. 17, 1978, UNDA/CCUM Papers, Folder 23/19.

${ }^{11}$ Catholic University of America Archives, "George Gilmary Higgins: An Inventory of the George Gilmary Higgins Papers at the American Catholic History Research Center and University Archives," http://archives.lib.cua.edu/findingaid/higginsfa.cfm?fullsite=1 (accessed 10.13.2013).

${ }^{12}$ John J. Egan, interview by George Costello, South Bend, IN, May 2, 1980, ACUA/GGH Papers, Box 434 , folder $14,10$.
} 
Bernardin's "background and ... knowledge of George Higgins' work either did not understand this or thought it unimportant." ${ }^{, 13}$

Soon after the dismissal became public, Egan traveled to Washington, D.C., and asked Higgins if he would object to Egan "mobilizing” his supporters. Higgins simply responded, "Jack, I'm going under a tree, you do whatever you want." ${ }^{14}$ Following their meeting, Egan returned to South Bend and formed a "small ad hoc committee" with the express purpose of saving Higgins, and within a short amount of time the "thing began to develop and hundreds of people came in." Dividing up their labors, Egan's committee contacted "labor unions, Jewish organizations, the economical groups, the Catholic organizations, the key bishops," and the like, and asked them for aid in their effort to reinstate Higgins. According to Egan, the response was incredibly positive, and in most instances, it consisted of the simple question, "Jack, what do you want me to do?" In return, Egan expressed the desires of his informal committee:

What we wanted to do was that we did not want to have overkill. All we wanted was for George to be reinstated, without embarrassing the Executive Committee of the bishops, without embarrassing the Administrative Board, in a sense that could be worse. Everything was done very quietly. ${ }^{15}$

Following these guidelines, Egan organized a letter campaign, whereby he called upon select, "distinguished people" to contact the bishops of the Committee and ask them to reconsider their position. ${ }^{16}$ Unlike Greeley's personal efforts, these letters were meant to

\footnotetext{
${ }^{13}$ John J. Egan to Joseph L. Bernardin, October 31, 1978, ACUA/GGH Papers, Box 430, Folder 3.

${ }^{14}$ Egan, interview, 11.

${ }^{15}$ Ibid.

${ }^{16}$ At the same time Egan was conducting his letter campaign, Joseph O’Brien, the Chairman of the Association of Chicago Priests also called upon the board members and the priests of the Association to write letters requesting the reinstatement of Higgins, disputing the Committee's budgetary reason as "short-
} 
persuade the Committee members without insulting them. As a result, the "bishops didn't get 10,000 letters. They got a significant 300 letters from significant people." ${ }^{17}$

While those who wrote for Egan cannot be determined specifically, the personal letters the bishops received (aside from Greeley's) attest to the impact of Egan's campaign. Among the letters received by the members of the Committee, those of John Tracy Ellis, the renowned American Church historian; Edward H. Flannery, former Executive Secretary of the Secretariat for Catholic-Jewish Relations; and Cesar Chavez, President of the United Farm Workers stand out. John Tracy Ellis, wrote Archbishop John R. Quinn of his dream

that Monsignor George Higgins was dead. It was good to wake and realize that George was hale and hearty! Needless to say, I attach no significance to the dream, even if it may have been a subconscious reminder of my failure to express my regret at the action of the NCCB-USCC Executive Committee.... I wish only to add my voice, belatedly, to the many that have been raised in protest since the Executive Committee's action became known. ${ }^{18}$

Edward H. Flannery joined Ellis in writing Quinn, stating that he was "particularly disturbed to learn of the premature retirement of Msgr. George Higgins," and that while he did "recognize of course the necessity of financial cutbacks, reorganization of departments and staff personnel, and the like," he felt "that in Monsignor's case these considerations have been given a priority over more important intangibles, such as,

sighted" (Joseph O'Brien to the Board Members of the Association of Chicago Priests, Oct. 16, 1978, UNDA/ACP Papers, Folder 14/27). Besides O'Brien's and Egan's effort, Patrick J. Sullivan, as a representative of the Catholic Committee on Urban Ministry, organized a petition on behalf of the effort to reinstate Higgins. The petition was signed by 300 members of its Fall Conference, and sent to the bishops of the Committee for Research, Plans and Programs (Patrick J. Sullivan, C.S.C., to Thomas Kelly, O.P., October 25, 1978, UNDA/CCUM Papers, Folder 23/19).

${ }^{17}$ Egan, interview, 12.

${ }^{18}$ John Tracy Ellis to John R. Quinn, November 10, 1978, ACUA/GGH Papers, Box 430, Folder 2. 
wisdom, experience and competence." Furthermore, for the Committee to "treat a person of these gifts and accomplishments in such a routine manner as to retire him ahead of time and thus save the Conference a relatively small sum of money seems to me to reflect more on the Conference than on the value or usefulness of Msgr. Higgins." Softening his critique, Flannery closed the letter stating that he said "these things, if rather directly, nonetheless with deference and charity." Personally, he believed "a mistake has been made which points to deeper dangers of policy and administration," and felt that he "should share my misgivings." 19 Rounding out the contributions of Ellis and Flannery, Cesar E. Chavez expressed his support of Higgins, stating "without hesitation that no single person in the Church has done as much for U.S. working people as Monsignor Higgins," and that there was "no one who has the knowledge, understanding and rapport with the labor movement that Monsignor Higgins has developed over the years." Consequently, he questioned whether the "action signifies a step backward for the Church or whether it means the Church is withdrawing from its advocacy of social justice issues, particularly the cause of working men and women in America."20

As the November meeting of the bishops drew near, Egan once again contacted Higgins. This time, instead of asking Higgins for permission to act, he called upon him to defend himself for the cause of social justice. Framing his request as "a favor," he asked Higgins to not "underestimate your importance in this matter," and to not "play it down by indicating in any way that you are sort of indifferent to the whole thing." For while his supporters

\footnotetext{
${ }^{19}$ Edward H. Flannery to John R. Quinn, Oct. 27, 1978, ACUA/GGH Papers, Box 430, Folder 2.

${ }^{20}$ Cesar Chavez to Thomas Kelly, O.P., Oct. 25, 1978, ACUA/GGH Papers, Box 430, Folder 2.
} 
admire the way you are handling yourself in this whole thing ... several Bishops and others who called me are of the opinion - as are many other people - that you don't want anybody to do anything either to have your decision reversed, or to get somebody in the office whom you might train, etc. etc.

If you give the impression in the next few weeks that your being dismissed is relatively unimportant or insignificant, or merely just a matter of it being a year from when you would have retired anyway, then it will, in my opinion, give out signals that everything is $\mathrm{OK}$ and that what the Plans and Programs Committee did was acceptable to you.

That, it seems to me, will hurt the cause and the work of so many to assure that this does not signify a pull-back from social action by the official Church. $^{21}$

Egan's efforts to reinstate Higgins were successful. On November 12, 1978, the Committee withdrew its request for Higgins's early retirement from the body of bishops. In its drafted statement the Committee acknowledged that some "reactions to the decision ... concerning Msgr. George Higgins reflected the belief that the Committee was unappreciative of his contributions and unconcerned with the social justice issues with which he is identified." The Committee denied these charges, stating that it was "fully aware of Msgr. Higgins' long service and distinguished contributions," and "like the rest of the bishops' Conference, is also fully committed to the cause of social justice and human rights." Consequently, the Committee withdrew its request of retirement for Higgins, and recommended the restoration of the Secretariat for Human Values. ${ }^{22}$ At the same time, Higgins received a new title as the Secretary for Special Concerns, effective

\footnotetext{
${ }^{21}$ John J. Egan to George Higgins, November 2, 1978, ACUA/GGH Papers, Box 430, Folder 3.

${ }^{22}$ USCC Draft for the Committee on Research, Plans and Programs, November 11, 1978, ACUA/GGH Papers, Box 429, Folder 8.
} 
on January $1,1979 .{ }^{23}$ He remained in this position until his official retirement on

September 1, 1980.

Following the victory, Egan encouraged Higgins to secure his position with the

Committee by reminding them of the services he provided:

I also truly hope you will do the memorandum that you promised me you would do, which would delineate your multitude of activities so that both Tom Kelly and the Plans \& Programs Committee, as well as the Administrative Board, will know what you are doing. I think you have been very humble and reserved in the past about your multitude of activities, and it's about time that this is brought up front. ${ }^{24}$

Besides such advice, Egan continued his efforts to secure Higgins's legacy, and through him the bishops' dedication to the social action movement. Writing Higgins, he expressed that it was

a joy for me to participate in some small in this most important battle for I truly believe that if we had lost, it would have affected social action work across the county for many years to come - it would have left a cloud which would not be easily dispelled even by succeeding administrations at the USCC. ${ }^{25}$

For Egan, the victory meant that "now we come out of this fight closer to labor and also closer to one another in the social action movement." This did not mean the battle was over, however. If Higgins's legacy - and its impact on the social action movement - was to be preserved, Egan recognized that a successor had to be trained. Egan's friend, Jim

\footnotetext{
${ }^{23}$ Jim Castelli, "Bishops Reverse Decisions on Controversial Staff Cuts," N.C. News Service, June 13, 1978, ACUA/GGH Papers, Box 429, Folder 8.

${ }^{24}$ John J. Egan to George Higgins, Nov. 22, 1978, ACUA/GGH Papers, Box 430, Folder 3.

${ }^{25}$ Ibid.
} 
Ford, the Assistant Director of the Catholic Committee on Urban Ministry of Notre Dame, already had a potential candidate for the position. Egan believed that Ford was "right on target" about the importance of securing Higgins's successor, "and that we have to begin campaigning now to get the right person to be trained by you and introduced around town so that in some way your work will continue beyond your period of retirement. ${ }^{, 26}$ Anticipating that Higgins might disregard the need for such action, Egan made a personal appeal:

You may think that the work is so personal to you that it cannot be passed on to another. Frankly I do not believe this and would hope that you give the matter serious attention so that when you do lay down the responsibilities some years from now (and certainly not when you are 65), there will be another or others to continue your work in the many arenas which you have been so active in. ${ }^{27}$

Unfortunately, it appears that this effort to secure a successor to Higgins never came to fruition. At the time of Higgins's official retirement, he expressed that

I stayed here [in the department] long enough to establish a contact with the labor movement that couldn't have been developed in any other way ... I'd say in all modesty that if they found a priest tomorrow for the staff and told him, 'The only thing we want you to do is keep in touch with the labor movement,' he couldn't do it in less than five years. Or 10 years. It would take him that long to get his credibility established ... A fellow would have to be here 10 years before they'd even let him in the [UAW] hall. ${ }^{28}$

\footnotetext{
${ }^{26}$ Ibid.

${ }^{27}$ Ibid.

${ }^{28}$ Gerald M. Costello, Without Fear or Favor: George Higgins on the Record (Mystic: Twenty-Third Publications, 1984), $67-68$.
} 
Bernardin voiced a similar view during his interview with Costello on March 28, 1980. In response to Costello's question as to whether there would be a successor to Higgins, Bernardin replied:

I'm not at all sure there's going to be a successor. The whole situation has changed now. And the focus is not so much on the individual as on a team. And I just think in the area of social concern, it will be a team working together, within the department, that will do what has to be done. It may well be that another person like George will emerge and kind of establish his own identity. But that may not happen. I don't see anyone else on the horizon. Someone able to step into that position - that role. Aside from not seeing anybody the thing is structured in such a way that likelihood is less. I'm not arguing that's good or bad, I'm just saying ... more and more priests that come into this kind of work, they come in for a limited period of time. In the future we aren't going to see priests stay in the same job as long as George stayed in this one. You'll see them coming in for three years or so. Not thirty-five or forty years. I just think that times are different and the structures are not amenable to this. ${ }^{29}$

Given that Bernardin had served as both the general secretary of the USCC and as President of the NCCB, and that he had played a role in creating the structures that dictated how the Conference's departments operated, the question remains as to whether this was by design. Unfortunately, the United States Catholic Conference of Bishops (USCCB) has not released the documents for this period. Besides this question, others still remain surrounding the decision by the CRPP to retire Higgins, and whether or not the decision was truly due to budgetary concerns. Once again, the USCCB has not released these documents. Fortunately, the interviews conducted by George Costello during his work on Without Fear or Favor: George Higgins on the Record, along with

\footnotetext{
${ }^{29}$ Joseph Bernardin, interview by George Costello, March 28, 1980, ACUA/GGH Papers, Box 434, Folder $6,9-10$.
} 
correspondence between Higgins and members of the USCC, provide some insight into the decision.

\section{Budget Cuts or an Agenda: The Undercurrents and Accusations of the Committee's Decision}

Throughout the dispute over Higgins's dismissal, his supporters questioned the real motives of the CRPP, refusing to believe that it was simply a budgetary matter. The National Catholic Reporter, and independent Catholic weekly newspaper founded in 1964, touched upon this during its coverage of the event, noting that "Egan and others say they cannot figure out why the bishops are dismissing Higgins," and that many implied the Committee's budgetary explanation simply camouflaged some other reason for his dismissal. ${ }^{30}$ Two prevailing theories gained traction during the controversy, one being "that it is because he has been forceful in pushing the notion that Catholic teachings on the rights of workers to organize should apply to all workers, including those in Catholic schools, hospitals and other institutions," and the other being Higgins's displeasure with Archbishop Bernardin's “thinly veiled endorsement of Gerald Ford in the last election." 31

\footnotetext{
${ }^{30}$ Rick Casey, “George Higgins' Ouster: I'm Angry,” National Catholic Reporter, October 27, 1978, ACUA/GGH Papers, Box 435, Folder 1; Founded by Robert G. Hoyt, the National Catholic Reporter was the first Catholic independent weekly newspaper. Prior to its arrival in 1964, most Catholic newspapers in America were published either by the dioceses of the Church or religious orders. As an independent Catholic paper, The National Catholic Reporter was known for its willingness to delve into the private matters of the Church (Peter Steinfels, "Robert G. Hoyt, 81, Founder of National Catholic Reporter," The New York Times, April 12, 2003).

${ }^{31}$ Ibid.
} 
As one might suspect, the bishops of the CRPP publicly maintained its argument of budgetary concerns both during and after the crisis. Bishop Tom Kelly, in response to Fr. Joseph O'Brien, the Chairman of the Association of Chicago Priests, stated that the termination of Monsignor's services is a disappointment for those of us who are his colleagues. The move is a result of an inflationary economy, and reflects cutbacks being made in Church organizations at all levels. Even an increase in income, uncertain at this moment, will barely permit the Conference to operate on its mandated nondeficit basis in 1979; and it appears impossible for us to contemplate a 1980 budget without further cuts. Since Monsignor would be retiring at the beginning of 1981, it seemed practical to approach him about an early retirement. ${ }^{32}$

In addition to this presentation, Archbishop Joseph Bernardin suggested that Higgins had inadvertently created the situation by choosing to become the Secretary for Research in 1972. A primary example of this rationale may be seen in Bernardin's response to Jack Egan on Oct. 23, 1978:

All I can do in this letter is give you the reasoning on which the Research, Plans and Programs Committee based its decision. The Conference is facing budgetary difficulties. Even with an increase in the diocesan quotas next year (for which authorization from the Ordinaries has not yet been obtained), some cutback is necessary. The reason George's office was singled out as one of the two offices to be closed is that when the Conference was reorganized some eight or ten years ago, it was the intention to place all social issues, including labor, in the new Department of Social Development (which was subsequently combined with the Department of International Affairs). At the time, we wanted George to head up the new department but he declined because he did not want to become involved in administration. I understood and accepted George's decision. In order to take advantage of George's expertise, a special office was set up for him. It was called the Office of Research and placed him under the General Secretary. Actually, George never did research in the

\footnotetext{
${ }^{32}$ Thomas Kelly, O.P. to Fr. Joseph O’Brien, Oct. 20, 1978, UNDA/ACP Papers, Folder 14/27.
} 
technical sense but continued doing the work he had been doing earlier for the Conference. While nothing explicit was ever said, there was always a danger that in some budgetary crunch this office might be discontinued, since it was established to provide a base of operation for one person and since, too, the de facto concerns of the office paralleled those of the Department of Social Development - World Peace. ${ }^{33}$

Consequently, according to Bernardin and Kelly, the decision to retire Higgins had always been a budgetary possibility ever since the creation of the Office of Research. Furthermore, since the Department of Social Development was a permanent office within the USCC, and since his work aligned with that Department, it was assumed that it would carry on Higgins's work after he retired. ${ }^{34}$

To Bernardin's credit, Higgins later confirmed this recollection of events. During a transcribed conversation with Frank Maurovich of the Religious New Service, Higgins acknowledged that he had been offered the directorship of the Secretariat of Social Development and World Peace, which had formed after the USCC merged the Department of Social Development with the Department of International Affairs in $1972 .{ }^{35}$ The relevant portion of the transcript is as follows:

This must be put in historical perspective. When they reorganized the Conference after the Council and the Booz-Allen study, they established a Department of Social Development and World Peace. I was previously Director of the Social Action Department. They asked me to head up the new Department and I declined. I told them I had been here for 25 years

\footnotetext{
${ }^{33}$ Joseph Bernardin to John J. Egan, October 23, 1978, ACUA/GGH Papers, Box 430, Folder 3.

${ }^{34}$ Bernardin reasserted these beliefs in his interview with George Costello on March 28, 1980. Bernardin believed that the question of Higgins's retirement would never have been approached if the CCRP "hadn't been faced with an insufficient amount of money, with all the things that the conference was doing," and if the Department of Social Development didn't perform the same work that Higgins had (Bernardin, interview, 5).

${ }^{35}$ Religious News Service, "Budget Cut Results in Bishops’ Agency Dropping Msgr. Higgins After 34 Years,” October 13, 1978, ACUA/GGH Papers, Box 429, Folder 8.
} 
and I am a strong believer in new blood and to get a new face. They said alright, would you be interested in staying on and sort of free lancing. I said yes. They indicated I would have to have a title and they created a legal fiction title personal to me. There is no Department of Research - the title was absolutely meaningless as far as my work was concerned.... If I had been killed or left, the office would not have been kept in existence. Social Development handles social action. ${ }^{36}$

In truth, Higgins preferred to work as the USCC's Research Secretary since it allowed him to pursue his interests without administrative demands. ${ }^{37}$ On June $30^{\text {th }}, 1972$, he wrote Cardinal John Cody, his ordinary in Chicago, and informed him of the change in title and position, which had taken place on June $15^{\text {th }}$. Higgins stated that he was

very pleased about my new situation in the Conference. Bishop Bernardin has been kind enough to relieve me of a number of administrative chores and has assured me that, while he wants me to be available for consultation with him and his staff on a number of Conference-wide matters, he also wants me to continue to pursue my own interests in the field of social action. ${ }^{38}$

Neither were Higgins and Bernardin alone in their recollections of that period.

James S. Rausch, former General Secretary of the USCC and the Bishop of Phoenix, Arizona, believed that "if you were looking for administration out of George Higgins you were looking in the wrong place." However, Rausch asserted there were other reasons for Higgins's move to become the Secretary of Research. According to Rausch, it was

\footnotetext{
${ }^{36}$ George Higgins, transcribed conversation by Frank Maurovich, Oct. 13, 1979, ACUA/GGH Papers, Box 429, Folder 8.

${ }^{37}$ Religious News Service, “Budget Cut Results In Bishops’ Agency Dropping Msgr. Higgins After 34 Years," October 13, 1978, ACUA/GGH Papers, Box 429, Folder 8.

${ }^{38}$ George Higgins to John Cody, June 30' 1972, ACUA/GGH Papers, Box 10, Folder 2.
} 
apparent that Higgins and the new director of the Department for Social Development and World Peace, John Cosgrove, did not work well together. It was

very evident that George, operating under Cosgrove ... was never going to work. The two of them came from different places. They approached issues very differently, I think. While there was a respectful relationship, certainly Cosgrove respected Higgins. I think Higgins felt Cosgrove was very much a lightweight.... So George was off doing his thing, in a very real sense. Not plugging into the Cosgrove operation; not as a junior staff member certainly, or as an underling to Cosgrove. ${ }^{39}$

Complicating matters, Higgins had become involved with the UFW conflict in California during this period of time, which only contributed to an attitude of detachment from the Conference. Rausch argued that

George looked upon the world peace - social development thing as the thing he liked least about bureaucracy; a lot of paper-shuffling, a lot of memorandums, a lot of query, but not the kind of substance the operation needed.... So George was looking at that whole operation of international affairs and social development as soft and mushy. He delved very deeply into the California problem - problems such as settling a dispute and assuring the rights of the United Farm Workers and the farmers in general. $^{40}$

Furthermore, Higgins had become so involved in the UFW conflict in California, that it put many of the bishops on edge. "Questions were raised about, 'Are we getting too specific, are we endorsing, are we becoming a tool of the union, a peace making force between labor and management?",41 Complicating matters, the bishops' unease was

\footnotetext{
${ }^{39}$ James Rausch, interview by George Costello, Phoenix, AZ, February 21, 1980, ACUA/GGH Papers, Box 437, Folder 16, $4-5$.

${ }^{40}$ Ibid., $5-6$.

${ }^{41}$ Ibid., 6.
} 
exacerbated by their suspicion that whenever Bishop Joseph Donnelly, the chairman of the Bishops' Ad Hoc Committee on Farm Labor, spoke, his words “had been prepared by Higgins." As a consequence, the bishops "saw Joe Donnelly as more or less a front, for Higgins. ${ }^{, 42}$ It was during this time that Rausch realized that if

the Conference decided, for whatever reasons, to disband that committee [the Bishops' Ad Hoc Committee], then George was out here on a limb. His position in Social Development didn't amount to anything because he had, in effect, disassociated himself. ${ }^{43}$

At the same time, the bishops began to question whether Higgins's actions served the Conference and the bishops as a whole. Rausch attested that "their concern was ... why is the conference paying a salary for him, a secretary for him, to do his thing? Staff does the work for us, and the question was does Higgins work for us?" The momentum behind these questions only accelerated once Cardinal Krol became President of the Conference, for "Krol was much stronger on this question than his predecessor." 44 As a result, Rausch sought to protect Higgins once he became the General Secretary in December of 1972. Rausch originally proposed that Higgins "be made a Special Assistant to the General Secretary," but John Hotchkin, the Director of the Secretariat for Ecumenical and Interreligious Affairs of the USCC, advised him not to pursue such a course. From Hotchkin's perspective, such a position would have been demeaning to Higgins. Consequently, it was following his conversation with Hotchkin that Rausch "came up with the idea of naming George Secretary for Research, for the conference." The beauty of such a maneuver was that Higgins "could define his own position," which in a sense

\footnotetext{
${ }^{42}$ Ibid., 7.

${ }^{43}$ Ibid., 6 .

${ }^{44}$ Ibid., 8.
} 
he had already done. Rausch simply wanted to "institutionalize the position." 45 Unfortunately, even with the official title and Rausch's protection, the bishops' questioning of Higgins's role within the Conference only subsided during Rausch's tenure as General Secretary from 1972 to 1977 . According to Rausch, they were "never ... completely gone. It was always there but it never surfaced. ${ }^{46}$ When Rausch left his position as General Secretary of the Conference, these questions broke through to the surface.

Given the circumstances surrounding Higgins's dismissal, Rausch questioned whether Bernardin was "the prime mover" in the CRPP's decision. Once Rausch heard about the dismissal, his "concern became very much George Higgins," and he decided to take action by contacting John Roach, the Archbishop of Minneapolis-St. Paul and Vice President of the NCCB. According to Rausch, he and Roach "discussed the possible solutions to the problem," after which Rausch was contacted by Bernardin. The fact that "Roach obviously called Bernardin" surprised Rausch, who did not understand "why Bernardin became the principal contact in this situation, or why it wasn't the president of the conference," John Quinn. Knowing that Bernardin was the former president, Rausch asked himself "why it would be Bernardin that Roach would contact about [his] call," and that it was the two of them who had "a discussion of what to do." Consequently, the fact that Bernardin contacted him about his inquiries to Roach raised suspicions of his involvement. ${ }^{47}$ These suspicions were only bolstered by Bernardin's later actions, when he "became the solver of the problem." According to Rausch, it was Bernardin who had

\footnotetext{
${ }^{45}$ Ibid.

${ }^{46}$ Ibid., 9.

${ }^{47}$ Ibid., 11.
} 
proposed "the approach to go to the Administrative Committee" of the USCC and petition that the decision be reversed. Even before the meeting of the Administrative Committee, Bernardin called Rausch to inform him "that this is what was going to happen." In recollection of these events, Rausch once again doubted Bernardin's role, but was unwilling to accuse Bernardin outright that he had been behind the move to dismiss Higgins. While he saw Bernardin as the "prime mover," he did not "know to what extent he was a creator of the fact." ${ }^{48}$

If Rausch's fears were justified, and Bernardin was the "prime mover" in Higgins's dismissal, the question remains as to why he pursued such action. George Costello, in his interviews for Without Fear or Favor: George Higgins on the Record, hoped to figure out the answer, even though he did not plan on incorporating it within his biography of Higgins. ${ }^{49}$ As one might suspect, none of the individuals interviewed by Costello were willing to charge any one person as responsible for the decision, at least on the record. However, many commented on their beliefs surrounding the dismissal and who might have been responsible. Furthermore, the investigative trail that Costello pursued seems to imply that Bernardin was not the only individual that may have contributed to the decision. Instead, Costello uncovered a trail that also led to Cardinal Krol. Unfortunately, the documentary evidence left by Costello's interviews is limited, especially since some of his interview subjects spoke off the record. In his interview with Arthur Goldberg, former Supreme Court Justice and Secretary of Labor, Costello asserted that he had "been told, even in more direct fashion by people who would be in a position to know" that it was Cardinal Krol who was ultimately responsible for the action of the

\footnotetext{
${ }^{48}$ Ibid., 12.

${ }^{49}$ Arthur Goldberg, interview by George Costello, ACUA/GGH Papers, Box 434, Folder 16, 12.
} 
Committee. In particular, one individual asserted that "Krol told him that one of his jobs was to get rid of Higgins," but had required Costello to "turn the tape recorder off" during that portion of the interview. Complicating matters, the record is unclear as to who this individual was, as Costello did not refer to him by name. ${ }^{50}$

The assertion made by Costello may provide some insight as to whom the unnamed source may have been, given its context. The individual in question had to have held a position that would have enabled him to remove Higgins. If the individual did not, then Krol's charge does not make much sense. Complementing this is the fact that Costello only conducted interviews with two members of the CRPP, Thomas Kelly and Joseph Bernardin. Bernardin was Krol's successor as president, having assumed the post after Krol in 1974, and it stands to reason that if Krol had charged anyone with such a task, it would have been his successor. This, when combined with Costello's charge that Krol was an integral party to the decision, and Rausch's belief that Bernardin was the "prime mover" of that decision, gives credence to the charge of that there were ulterior motives behind the decision to retire Higgins early. Bernardin could have been acting under the influence or on behalf of, or in solidarity with, Krol's request, who, according to Rausch, focused on the question of Higgins's ties to the Conference during his presidency. Consequently, the documentary trail created by Costello's interviews suggests there was more to the decision to retire Higgins than budgetary concerns alone, and that Higgins's supporters were justified to question the CCRP's decision. However, if the CCRP indeed made its decision outside of budgetary concerns, the question remains as to why the Committee attempted to remove Higgins from a position of influence.

\footnotetext{
${ }^{50}$ Ibid.
} 
The decision to remove Higgins may have been as simple as Rausch suggested in his interview. Higgins had refused to be a director within the Conference, a decision which potentially marginalized his role within it. At the same time, by disassociating himself and working on the California farmworker conflict, Higgins risked being seen as a maverick by the bishops and within the Conference. This may very well have raised questions concerning Higgins's work, and whether his actions truly represented the wishes of the bishops, or whether they represented a personal agenda. However, as noted in the National Catholic Reporter, Higgins's supporters also questioned whether his endorsement of unionization within Catholic institutions and his stance on the Democrat's Abortion Platform in 1976 played some role in his dismissal. While the record shows that Higgins did address these issues, particularly with Cardinal Krol on the issue of unionization of Church institutions and with Bernardin on his implied support of Gerald Ford in the 1976 election, it does not support the claims that these two issues played a role in his early retirement.

\section{Church Unionization and the NLRB: Krol's Demand}

On October 3, 1976, Higgins addressed the National Catholic Educational Association (NCEA) in Bethesda, Maryland on the issue of teachers' unions in Catholic schools. During the course of his presentation, Higgins acknowledged he had not approached the issue since 1968, when he had attended a seminar hosted by the U.S. Catholic Conference Education Department. In spite of this gap, his views remained very much the same; he believed "without equivocation that teachers have the right to organize and bargain collectively and that school administrators have the duty to honor 
this right in practice." ${ }^{51}$ Yet, he also recognized that the circumstances of the debate over teacher unionization had radically changed in the past 8 years. While the questions of whether teachers could organize and whether those of religious orders could belong to unions had remained the same as it had in years prior, the conflict these questions created had been heightened by the National Labor Relations Board's claim of jurisdiction in these matters.

Higgins declined to weigh in on whether the actions of the NLRB were justified, as he believed it would have been "awkward ... as a USCC staff member, to voice any opinion about it." Instead, Higgins expressed his hope "that this highly volatile issue will not be used as a delaying tactic and will not distract the parties from facing up to the essential question confronting all of us, namely, the right of teachers to organize into a union of their own choice and to bargain collectively with their employers." ${ }^{52}$ Higgins believed this remained the key issue, especially for Catholic teachers and their administrators. There was no perfect world when it came to this issue, including whether the institution in question was religious or not. As Higgins understood it, in

a more perfect world, in a utopian world, there might be a better way to carry on human relations in the economic field than to do it through unions, but we do not live in that kind of world. And the notion that because we are connected in some way or another with Catholic institutions, or even worse, the notion that because we graduated from a Catholic nursing school and are now working in a non-Catholic hospital or health situation, and therefore should not get involved in this rather 'dirty' business of trade unionism, is as dead as the dodo.

\footnotetext{
${ }^{51}$ George G. Higgins, “Teachers' Unions in Catholic Schools," Catholic Mind, February, 1977, ACUA/GGH Papers, Box 332, Folder 9, 19.

${ }^{52}$ Ibid.
} 
We live in a real world in which most people, in one form or another, are going to carry on an economic relationship through organization. To fight it under some confused understanding of the vow of poverty, or of the independence of church-related institutions, would be a serious mistake. ${ }^{53}$

As a consequence, Higgins advocated that "administrators of Catholic institutions should strike out on their own and, for once, take the lead in establishing progressive labormanagement relations in their particular profession. There is no reason why they can't do it, and every reason why they should. ${ }^{, 54}$ Furthermore, if they did not, and instead gave the "impression at this late date that they were using legalistic arguments to oppose the right of teachers to organize into a union of their own choice and to bargain collectively," then only harm would come to the image and standing of Church on this issue. ${ }^{55}$

Higgins's talk did not escape notice. On October $13^{\text {th }}$, Krol, noting Higgins's address at the NCEA meeting, sent him a copy of the U.S. District Court of Indiana's decision in Grutka v. N.L.R.B, whereby "the Court ruled that the case involved both a jurisdictional and a constitutional issue," and so "enjoined [the NLRB] from any further action. ${ }^{56}$ The case had gone to trial in November of 1975, petitioned by Andrew Grutka, the bishop of Gary, Indiana. On October 21, 1975, a diocesan priest had informed Grutka "that he had been served with a petition for certification of representation by the National Labor Relations Board, Region 13, along with a notice of representation hearing to be held by the Board. ${ }^{, 57}$ Grutka filed a motion with the Board to dismiss the certification, which was subsequently denied. As a result, Grutka petitioned the District Court to grant

\footnotetext{
${ }^{53}$ Ibid., 21.

${ }^{54}$ Ibid., 22.

${ }^{55}$ Ibid., 27.

${ }^{56}$ John Krol to George Higgins, October 13, 1976, ACUA/GGH Papers, Box 50, Folder 18.

${ }^{57}$ Grutka v. N.L.R.B., 409 F. Supp. 133 (U.S. District Court, N.D. Indiana, Hammond Division, 1976).
} 
a three judge court to determine the constitutionality of the Board's actions, as well as a temporary restraining order of the certification. Grutka's basis for his request was that the Board's actions violated his First, Fifth, and Ninth Amendment Rights, and that the Labor Management Relations Act was unconstitutional when applied in this manner. In turn, the NLRB argued that the court was without subject matter jurisdiction, and "that only under extraordinary circumstances does a district court have the power to review the Board's representation proceedings." ${ }^{\text {"58 }}$ The court granted Grutka's request on November 17, 1975. Krol praised the decision, which he believed acknowledged the right of the Church to support collective bargaining while resisting "the intrusion of a governmental regulatory agency into religion," a position that he assumed some people found "difficult to understand." $" 59$

Higgins responded by thanking Krol for his "thoughtfulness in sending ... a copy of Judge McGagney's [sic] decision in the Hammond NLRB case," and thanked him for bringing it to his attention. ${ }^{60}$ Higgins then proceeded to explain his talk at the NCEA symposium, stating that he did not use the opportunity to "comment on the pending NLRB cases," since it would have been "improper for me to do so in view of the fact that these cases are still being litigated." Insofar as his own standing on the issue, Higgins asserted that he "did not find it difficult to understand the position of those who acknowledge the right of collective bargaining but, at the same time, argue on constitutional grounds that the NLRB should not be permitted to exercise jurisdiction over our schools." However, Higgins made clear that he consummately disagreed with

\footnotetext{
${ }^{58}$ Ibid.

${ }^{59}$ John Krol to George Higgins, October 13, 1976, ACUA/GGH Papers, Box 50, Folder 18.

${ }^{60}$ George Higgins to John Krol, October 15, 1976, ACUA/GGH Papers, Box 50, Folder 18; both Higgins and Krol misidentified the judge in the Hammond case. The judge's name was not "McGagney," but rather "McNagny."
} 
those who argued against collective bargaining at the symposium, and expressed his fear "that some of the Superintendents will go down fighting on the issue and will be tempted to use the pending NLRB cases as a delaying tactic." Higgins confided that he believed such action would constitute a "serious mistake" on the part of the superintendents, even if the courts eventually decided "on constitutional grounds, that NLRB cannot claim jurisdiction over Catholic schools." Regardless of the courts' decisions, Higgins asserted that "with or without NLRB jurisdiction, our schools will still have to face up realistically to the collective bargaining issue." At no point did Higgins state his position on the NLRB and its jurisdiction over Catholic schools.

Krol responded on the $18^{\text {th }}$, agreeing with Higgins's assessment that "collective bargaining is a right which cannot be denied and should not be delayed." At the same time, however, he asserted that the Church would "challenge every attempt of the government to impose regulation over our schools, which the Supreme Court says are too religious for government aid and which the N.L.R.B. says are not too religious for government entanglement and regulation." ${ }^{, 61}$ The message was clear. Krol expected Higgins's support against the NLRB and its effort to regulate Catholic education, or at the very least, Higgins's silence on the issue. The record shows that Higgins honored Krol's wishes on the matter, insofar as he could. While he did not publicly support NLRB jurisdiction, neither did he fight against it. Instead, he took very much the same path he had in response to Krol's first letter. Higgins backed the rights of teachers to unionize and bargain collectively, and argued that the conflict over NLRB jurisdiction did not influence whether or not teachers held such rights.

\footnotetext{
${ }^{61}$ John Krol to George Higgins, October 18, 1976, ACUA/GGH Papers, Box 50, Folder 18.
} 
On the same day Higgins received Krol's final reply, he published his views on the matter in his Yardstick column. The column repeated much of what Higgins had stated to Krol - that since the matter of NLRB jurisdiction had not yet been decided by the courts, "it would be awkward ... as a USCC staff member, to voice an opinion" on it. In the same breath, however, Higgins voiced his opinion that

teachers unions are here to stay and we had better learn how to deal with them constructively," and expressed his "hope that this highly volatile issue [of NLRB jurisdiction] will not be used as a delaying tactic and will not distract the parties from facing up to the essential question confronting all of us: the right of teachers to organize into a union of their choice and to bargain collectively with their employers. ${ }^{62}$

If this question was not answered in the appropriate way, meaning the recognition of these rights, then Catholic superintendents invited "the kind of trouble that could divide the Catholic community for many years to come." Such a scandal "would predictably do almost irreparable harm to the Catholic school system in the United States." ${ }^{\text {.63 }}$

Later Yardsticks followed the same tact, as Higgins supported teachers' rights to organize and bargain collectively, but at the same time did not argue the issue of NLRB jurisdiction. Instead, Higgins pointed out that if "the courts eventually decide ... that the NLRB cannot claim jurisdiction over Catholics schools," then this decision presented its own set of problems. In his opinion, such a decision would "not be the end of the collective bargaining controversy but, in a sense, only the beginning," because "with or without NLRB jurisdiction, our schools will still have to face up realistically to the

\footnotetext{
${ }^{62}$ George G. Higgins, "Catholic Teachers and Collective Bargaining," The Yardstick, October 18, 1976, ACUA/GGH Papers, Box 354, Folder 4.

${ }^{63}$ Ibid.
} 
collective bargaining issue." ${ }^{\prime 64}$ From Higgins's perspective, this meant negotiation would take place regardless of whether the NLRB was involved or not. Furthermore, if such was the case, it meant that Catholic school administrators would "have to develop a substitute set of ground rules or procedures to regulate their negotiations and to guarantee due process" for those parties who met at the bargaining table. ${ }^{65}$ Without such rules and regulations, there was "no way that collective bargaining in the Catholic school system can be made to work effectively.",66

On March 21, 1979 the Supreme Court settled the issue once and for all, ruling that the National Labor Relations Act did not apply to church-related schools, and arguing that NLRB jurisdiction would present "an unconstitutional entanglement of church and state." ${ }^{, 67}$ In response, Higgins maintained the stance he had taken in 1976, arguing that in respect to teachers the decision did "not negate their right to organize." He supported this view by citing the position of Bishop Thomas Kelly, the same bishop who, as a member of the CRPP, had decided to retire Higgins early in 1978. As general secretary of the USCC, Kelly "emphasized the importance of this distinction," and like Higgins, supported the economic rights of church-employed teachers. Consequently, once again, Higgins called for the creation of a "substitute for the NLRB," since Catholic school administrators would "need such a board to handle their labor problems in an

\footnotetext{
${ }^{64}$ George G. Higgins, "Are Catholic Schools Open to Collective Bargaining?” The Yardstick, November 1, 1976, ACUA/GGH Papers, Box 354, Folder 4.

${ }^{65}$ George G. Higgins, "Teachers in Catholic Schools: Unions and Collective Bargaining," The Yardstick, August 29, 1977, ACUA/GGH Papers, Box 354, Folder 7.

${ }^{66}$ Ibid.

${ }^{67}$ George G. Higgins, "Collective Bargaining Rights of Teachers in Church-Related Schools," The Yardstick, April 9, 1979, ACUA/GGH Papers, Box 354, Folder 14.
} 
orderly manner - to conduct representation elections, for example, and to process unfair labor practice charges." 68

The record proves that Higgins honored Krol's request concerning the NLRB's jurisdiction, but at the same time pursued what he considered to be the primary issue of the conflict over unionization within Church institutions - the right to organize and bargain collectively. By doing so, he stayed within the boundaries that Krol had set in his communication with him in October of 1976, two years prior to the effort to retire him early by the CRPP. After all, as Krol himself wrote, "collective bargaining is a right which cannot be denied and should not be delayed," and Higgins agreed both privately and publicly with that stance. ${ }^{69}$ Consequently, it does not appear that Higgins' efforts to secure the rights of workers in Catholic institutions came into play - at least through Cardinal Krol - during the CRPP's decision to retire Higgins. The same may be said concerning Higgins's challenge of Bernardin's implicit endorsement of Gerald Ford prior to the 1976 election due to his stance on the abortion plank of the Democratic Party's platform of that year.

\section{The Danger of a Single Issue: Higgins and His Stance on Abortion}

On June 11, 1976, the Drafting Subcommittee of the Democratic Party's Platform Committee adopted an abortion plank for its upcoming convention that was at odds with the efforts of the USCC. The Party had originally planned to take the same path as it had in 1972, and exclude any reference to abortion. This decision upset the pro-abortion

\footnotetext{
${ }^{68}$ Ibid.

${ }^{69}$ John Krol to George Higgins, October 18, 1976, ACUA/GGH Papers, Box 50, Folder 18.
} 
lobbying groups in attendance, however. As a result, the Subcommittee overwhelmingly adopted a new plank which stated that while the Party recognized "the religious and ethical nature of the concerns which many Americans have on the subject of abortion," it felt that it was "undesirable to attempt to amend the United States Constitution to overturn the Supreme Court decision in this area." The Subcommittee's actions were later upheld by the Platform Committee. USCC representatives in attendance believed the language adopted by the Platform Committee had been "drafted by Governor Carter's representatives, and ... was language he supported." Consequently, the USCC summarized the actions of the Platform Committee as the following:

the Platform Committee was dominated by delegates, who were willing to compromise on all of the so-called controversial issues for the sake of party unity. Many considered this plank a compromise. More importantly, Governor Carter and his representatives had almost complete control over the proceedings. They made a decision on where they wanted to go with the abortion issue, which was consistent with what Governor Carter had already publicly stated on the matter. ${ }^{70}$

On June 22, Bernardin, who still presided as President of the NCCB, publicly objected to the Democratic Party's abortion plank, specifically its statement that it was “"undesirable' to amend the Constitution to protect unborn human life." Such a stance was in direct opposition to the efforts of the USCC, which recommended a constitutional amendment "as the best - and indeed the only - way of restoring legal protection to the unborn." Bernardin believed the rejection of a constitutional amendment betrayed the true intent of the Democratic Party, even though Carter's representatives had framed it as

\footnotetext{
${ }^{70}$ USCC Memorandum, "Democratic Platform Statement on Abortion," June 21, 1976, ACUA/GGH Papers, Box 4, Folder 27.
} 
a compromise. According to Bernardin, it represented "a specific intent to express the Democratic Party's policy on abortion," and as a consequence betrayed the true intent of their elected officials. Consequently, those elected officials who "alleged personal opposition to abortion and personal disagreement with the Supreme Court's abortion rulings," but still supported the party plank, were neither "persuasive" nor "responsible" in their argument to the American public. ${ }^{71}$ Thus, Bernardin requested "every effort be made to persuade people to remain active participants in the governmental process," so that Congress would "pass an amendment protecting human life at every stage in existence. ${ }^{, 72}$ Privately, Bernardin also asked the bishops of the United States that they "bring this information to the attention of your people and ask them to take a more active role in the political process so as to assure passage of a constitutional amendment protecting human life at every stage.",73

Higgins wrote Bernardin the same day he released his statement and objected to it, "not because it criticized the section on abortion, but because it said nothing at all about any other issue." This was a mistake, for Higgins feared that it would "play right into the hands of those Catholics who ... want to make the forthcoming political campaign a one-issue contest," and would allow them to argue "that Catholics should vote for the Republican ticket in November and should do so exclusively on the basis of one issue and one issue only, namely, abortion." Intentionally or not, Higgins believed Bernardin had implicitly endorsed the Republican presidential candidate, Gerald Ford. Furthermore, Higgins believed that Bernardin's statement undermined the USCC

\footnotetext{
${ }^{71}$ Joseph Bernardin to the Bishops of the United States, June 22, 1976, ACUA/GGH Papers, Box 4, Folder 27, 2; This document contains both a form letter meant to address individual bishops explaining the issue, as well as the statement issued by Bernardin.

${ }^{72}$ Ibid., 3.

${ }^{73}$ Ibid., 1.
} 
statement, Political Responsibility: Reflections on an Election Year, published on

February 12, 1976. As a consequence, Higgins proposed that the two of them meet to discuss the USCC's commitment to the ideals expressed in Political Responsibility, and how they might best implement those ideals as a team. Cognizant that his letter might be interpreted in a negative light, he reassured Bernardin that his correspondence was a "strictly personal letter," and that he had not discussed its contents with anyone except James Rausch and Thomas Kelly, to whom he had sent copies of his letter "as a matter of courtesy." ${ }^{74}$ Along the same lines, he made clear that he was "not suggesting for a moment that the staff ought to be permitted to make Conference policy." 75

As a Conference statement, Political Responsibility: Reflections on an Election Year deplored the trend of "alienation, disenchantment and indifference" present among the voting public, and urged

all citizens to register to vote, to become informed on the relevant issues, to become involved in the party or campaign of their choice, to vote freely according to their conscience, in a word, to participate fully in this critical arena of politics where decisions are made. ${ }^{76}$

It asserted that as members of the Church, Catholics had a special responsibility "to call attention to the moral and religious dimensions of secular issues, to keep alive the values of the Gospel as a norm for social and political life, and to point out the demands of the

\footnotetext{
${ }^{74}$ James Rausch was serving as the General Secretary at this time, while future bishop Thomas Kelly served as an associate general secretary (Marjorie Hyer, "D.C. Auxiliary Bishop Named New Archbishop of Louisville," The Washington Post, December 30, 1981).

${ }^{75}$ George Higgins to Joseph Bernardin, June 22, 1976, ACUA/GGH Papers, Box 4, Folder 27.

${ }^{76}$ Reprint of "Political Responsibility: Reflections of an Election Year," The Sisyphus Papers 4, no. 8 (June 1976): 12; The Sisyphus Papers may also be located online through Boston College: http://newspapers.bc.edu/cgi-bin/bostonsh?a=cl\&cl=CL1\&sp=bcsisyphus\&e=-------en-20--1--txt-IN----(accessed 10.13.13).
} 
Christian faith for a just transformation of society.” In essence, Catholics were called upon as citizens to "give serious consideration in all matters to the common good," and "to the welfare of society as a whole.",77

The USCC statement made clear that it did "not seek the formation of a religious voting bloc" in its promotion of such an effort. Neither did the Conference "wish to instruct persons on how they should vote by endorsing candidates." Rather, it asked its fellow Catholics to "examine the positions of candidates on the full range of issues as well as the person's integrity, philosophy and performance," and by doing so enrich the nation by making their civic decisions "from positions grounded in moral conviction and religious life. ${ }^{, 78}$ In order to help members of the Church make such decisions, the USCC statement outlined the "full range of issues" that required such consideration, which were as follows: abortion; the economy; education; food policy; housing; human rights and foreign policy; mass media; and military expenditures. As one might expect, Political Responsibility disagreed with the 1973 Supreme Court decision on abortion and supported a constitutional amendment to "restore the basic constitutional protection of the right to life for the unborn child," but it also explained the importance of other social issues as well. ${ }^{79}$ It argued that the nation had to make a commitment to the full employment of all its citizens; that "all persons of whatever race, condition, or age, by virtue of their dignity as human beings, have an alienable right to education;" that a person's sustenance played a part in their right to life, as did their right to decent housing; that "human dignity requires the defense and promotion of human rights;" that the mass

\footnotetext{
${ }^{77}$ Ibid., 13.

${ }^{78}$ Ibid., 14.

${ }^{79}$ Ibid., 15.
} 
media represent the public good and its interest; and that the arms race was a threat to all humanity in its promotion of mutual mass destruction. ${ }^{80}$ All of these issues had to be considered when it came to the political decisions of all Catholics - not just one of them.

By repeating the USCC's stance on the political landscape four months prior to his own commentary on the Democratic Platform, Higgins reminded Bernardin that the American Church's stance on abortion had to be placed within the context of other social issues of the day. Bernardin responded on June $25^{\text {th }}$, and expressed his appreciation of the letter, as well as Higgins's candor. He admitted that it was not his intention "to give the impression that abortion is the only issue which should be taken into account in the coming election," and recognized that "to do this would be contrary to the position taken by the USCC Administrative Board last February in "Political Responsibility: Reflections on an Election Year." Agreeing with Higgins, Bernardin questioned "how to address one issue without undermining others," and admitted that it was "not always an easy problem to resolve." This was due to the nature of the issue, which Bernardin believed had had "little institutional support other than our own, while so many of the other issues do have strong advocates other than ourselves." As a result, Bernardin believed that the pro-life position of the Church would always "generate a certain amount of tension." Regardless, he agreed that he should meet with Higgins, and welcomed "discussing the matter informally with you and the staff," as Higgins had suggested. Bernardin then closed the letter by thanking Higgins once again, and reassured him that he valued his judgment. ${ }^{81}$

\footnotetext{
${ }^{80}$ Ibid., $15-16$.

${ }^{81}$ Joseph Bernardin to George Higgins, June 25, 1976, ACUA/GGH Papers, Box 4, Folder 27.
} 
On August $16^{\text {th }}$ Bernardin took advantage of Higgins's advice, and released a statement meant to clarify the Church's stance on abortion in relation to the other social issues of the day, including its place within the upcoming November election. Bernardin's statement was very similar in form to that of Political Responsibility, arguing that it was "the Church's role to call attention to the moral and religious dimensions of secular issues ... and to point out the demands of the Christian faith for a just transformation of society." It acknowledged that in its teaching role, the "Church does have an influence on the political order," but that it did "not involve itself in partisan politics," or "endorse or oppose particular parties or candidates." The statement reflected Bernardin's exchange with Higgins, in that it affirmed abortion as one of many social concerns of the Church, which all "have to do, in one way or another, with the sanctity of life which is the most important issue of all." Consequently, Bernardin reminded his audience that human life was also "threatened $\ldots$ by hunger, inadequate health care, the lack of decent housing, and the proliferation of nuclear weapons, etc.," and not simply by abortion alone. He acknowledged the Church seemed "particularly concerned about abortion at the moment," but explained that this was due to its influence on the whole of society. The Church feared that if humanity accepted abortion, then humanity's "sensitivity to the entire spectrum of human rights will ultimately be eroded." In this sense, labeling abortion as a "Catholic issue" was a disservice. Bernardin argued that abortion was "a human rights issue which transcends denominational lines," and that the "fact that the Catholic Church has taken a forceful position does not make the issue a Catholic one ... no more than our involvement in the food crisis makes that a Catholic issue." As a consequence, Bernardin asserted that the Church would "closely watch all 
the issues and address them as the occasion demands" in the coming election, and offered to meet with either nominee to discuss the Bishops' Conference position. ${ }^{82}$

The day after the statement, Higgins wrote Bernardin and congratulated him on his "statement on the political role of the Church, as reported in today's News Service." He believed it was "just what the doctor ordered," and in his "opinion, it came just in time to avert a potentially harmful internecine squabble within the Catholic community on the current political campaign. ${ }^{, 83}$ For all intents and purposes, the matter between the two men was closed. Bernardin had clarified his original statement on the abortion plank of the Democratic Party, and in doing so had regained the air of political neutrality that was expected of American clergy and their bishops. Consequently, in regards to the early retirement controversy, the record shows that Higgins's stance on the 1976 Democratic Party's plank on abortion was not a factor, at least insofar as Bernardin was concerned. If anything, Bernardin benefitted from Higgins's input, and Higgins's actions helped Bernardin to remove himself from a potentially embarrassing public relations debacle. Even more telling, Bernardin continued to follow the path the Higgins had outlined for him in 1967, which led to his description of the entirety of Catholic social issues as a "Seamless Garment" in October of $1984 .{ }^{84}$ Bernardin had every reason to thank Higgins concerning this issue, as opposed to punishing him for it.

\footnotetext{
${ }^{82}$ NC News Service, "Church's Political Role is Clarified by NCCB Head," August 16, 1976, ACUA/GGH Papers, Box 4, Folder 27.

${ }^{83}$ George Higgins to Joseph Bernardin, August 17, 1976, ACUA/GGH Papers, Box 4, Folder 27.

${ }^{84}$ Marjorie Hyer, "Cardinal Bernardin Urges Rejection of 'Single-Issue Politics,"” The Washington Post, Oct. 26, 1984.
} 


\section{The End of An Era: Higgins's Official Retirement}

The Costello interviews, along with Higgins's correspondence with Cardinal Krol and Archbishop Bernardin, back the bishops of the CRPP and their claim that Higgins's early retirement was for budgetary reasons alone. In the two instances that Higgins may have crossed influential bishops of the USCC, the available evidence suggests that Higgins worked with the bishops in question, as opposed to fighting against them. Consequently, until further documentation becomes available, it appears that there was no ulterior motive to the actions of the CRPP. Instead, their actions represent an oversight by the Committee, and a complete misjudgment of - or lack of judgment on - the public reception to their decision. Furthermore, Higgins's decision to become the Secretary of Research in 1972 contributed to the actions of the CRPP six years later. By declining the position of director of the Secretariat of Social Development and World Peace, Higgins inadvertently positioned himself outside the traditional departments of the USCC. In a real sense, the decision to become Secretary of Research created the conditions which allowed his retirement due to budgetary concerns. Furthermore, if Higgins truly was disassociating himself from the social work of the USCC under John Cosgrove, and the CRPP believed that Higgins's work paralleled that of the Secretariat of Social Development and World Peace, one could certainly understand an executive decision supporting a department over an individual. Consequently, it appears that while a number of factors were part and parcel to the CRPP's decision to dismiss Higgins, none suggest an agenda against Higgins personally. 
On June 16, 1980, George Higgins submitted his resignation as the Secretary for Special Concerns, citing the NCCB-USCC's mandatory retirement age of 65. Higgins informed the bishops that he had considered "it a privilege and an honor to have been given the opportunity to serve the Conference," and wished to thank the bishops "individually and collectively for having made it possible for [him] to do so, and, in a more personal vein, to thank them for their many acts of kindness during" his years of service. ${ }^{85}$ He notified them that his duties at the NCCB-USCC would continue under the direction of Msgr. Francis J. Lally, the Secretary of the Department of Social Development and World Peace, and that he had accepted Bishop Kelly's invitation to serve as a part-time consultant to aid in the transition. With the approval of his ordinary, Cardinal John Cody, Higgins planned "to remain in Washington for the indefinite future," residing in Curley Hall at the Catholic University of America, where he would he serve as an adjunct professor teaching a course in Social Ethics. Besides his work at CUA, Higgins had accepted a position as a part-time consultant to Georgetown, where he could offer his social action expertise to the President of the university, Fr. Timothy Healy, S.J.

Serving in his role as General Secretary of the NCCB, Kelly publicly broke the news a little less than a month later, on July 7, 1980. After announcing Higgins's plan to retire from the Conference on September $1^{\text {st }}$, Kelly recognized Higgins as "a tireless advocate of social justice," who had challenged "the consciences of two generations of American Catholic clergy, religious and lay people.” Ultimately, Kelly commended Higgins as "a man of the Church," one whose life demonstrated "deep priestly commitment," and whose contributions had "brought to bear a unique blend of candor,

\footnotetext{
${ }^{85}$ George Higgins to the Bishops of the United States, June 16, 1980, ACUA/GGH Papers, Box 436, Folder 1 .
} 
conviction, and commitment to principle." ${ }^{86}$ After 36 years of service to the various incarnations of social action departments of the NCWC and USCC, Higgins's time at the Conference had come to end.

In the years that followed, Higgins continued in his role as professor at the Catholic University of America, retiring from the position at the age of 77 in $1994 .{ }^{87}$ All the while, his work on The Yardstick continued. After 56 years of writing the column, he wrote his last on September 10, 2001. He recalled that at the $25^{\text {th }}$ anniversary of the column, he had stated his plans to continue "writing 'The Yardstick' for the indefinite future." Unfortunately, he had not foreseen that a time "might eventually come when, for reasons of age and health, I might have to resign voluntarily." Higgins believed that those who wrote weekly columns were "compelled ... to do more serious reading than [they] might otherwise be prompted to do." The act of reading helped "prime the pump and to keep the well from going dry," and for Higgins, it enabled him to keep pace with the greater social issues of the day. Unfortunately, macular degeneration prevented him from this essential task. As a result, Higgins decided to retire from writing The Yardstick after writing nearly 3,000 columns. Reading the final column, it appears that Higgins believed a successor would take over the column; he wished them well, and hoped that a new writer would "enjoy writing the column as much as I have enjoyed it for so many years." However, it appears that no one took over the column. ${ }^{88}$ The time of The Yardstick had

\footnotetext{
${ }^{86}$ USCC News, "Msgr. Higgins, Retiring From Catholic Conference Staff, Hailed for Services," July 7 , 1980, ACUA/GGH Papers, Box 432, Folder 3.

${ }^{87}$ Jerry Filteau, “After 56 Years, Chicago's Higgins Ends Labor Column,” The Catholic New World, September 16 - 29, 2001, ACUA/GGH Papers, Box 365, Folder 22.

${ }^{88}$ George Higgins, "A Time for Goodbye After 56 Years," The Yardstick, September 10, 2001, ACUA/GGH Papers, Box 365, Folder 22.
} 
come to a close. Higgins himself soon followed, passing away on May 1, 2002. The American Church lost one of the great social activists of the $20^{\text {th }}$ century.

Similar to that of The Yardstick's successor, no one replaced Higgins at the time of his retirement from the USCC, or thereafter. While Fr. Lally took on Higgins's responsibilities by serving as the Secretary of the Department of Social Development and World Peace, he was not as well versed as Higgins in that role. According to Higgins's secretary, Nevila McCaig, Lally was a "great priest," but as a former journalist, he simply did not have the experience or the ability that Higgins had in the field of social action. This much was evident following the transitional period after Higgins's retirement. McCaig asserted that anytime Lally wanted "to know anything to do" in the field of social action, he seemed incapable of forming a strategy. Rather, he continually turned to her for advice since Higgins was no longer available. ${ }^{89}$ Furthermore, it appeared that the relationship between the Conference and its staff only contributed to this problem, as the Conference never retained personnel for substantial periods of time. If someone was going to serve as Higgins's successor, especially in the field of labor relations, this was a necessity. Many of the labor conventions met every third year, and since the staff was often not retained for even that long, it made it impossible to foster the relationships necessary to influence the movement. Consequently, when Higgins retired from the USCC it marked a shift in direction for the Conference and the American Church. No longer would it have a lone individual guiding the Church according to its social encyclicals; the time of John A. Ryan, Raymond McGowan, and George Higgins had come to a close.

\footnotetext{
${ }^{89}$ Nevila McCaig, interview by George Costello, July 9, 1980, ACUA/GGH Papers, Box 436, Folder 19, 7.
} 


\section{Epilogue}

George Higgins's retirement marked almost 36 years of service to the American Catholic Church. He considered himself fortunate to have had such an opportunity, thanking the bishops for allowing him "to carry on ... in the great tradition of the late Monsignor John A. Ryan, first Director of our Social Action Department." ${ }^{, 1}$ Undoubtedly, this tradition was a daunting one, but one which Higgins relished in his role as Assistant Director and Director of the SAD, and later as the United States Catholic Conference's Secretary of Research.

In many ways, Higgins's introduction to the SAD followed that of a "golden age" for the American Church in terms of social reform. Ryan had penned the Bishops' Program of Social Reconstruction in 1919, and had spent years advocating both its reforms and the living wage expressed in Pope Leo XIII's Rerum Novarum. His efforts were well rewarded, as many within the American Church believed Pope Pius XI's Quadragesimo Anno validated his views. Even further, many of the bishops' proposals from 1919 were adopted in some way, shape, or form by Franklin D. Roosevelt during the course of his New Deal in the 1930s. Primary among these stood the National Labor Relations Act of 1935, which was constitutionally confirmed in 1937 by the U.S. Supreme Court. The Act guaranteed the rights of workers to organize and bargain collectively, and hindered the efforts of employers to circumvent or hinder this organization. The protection of these rights was one of the central efforts of the SAD throughout its history, which was why Higgins believed that the Department's effort were best summarized

by quoting two brief sentences from one of Ryan's books written at the height of the Great Depression. 'Effective labor unions are still by far the most powerful

\footnotetext{
${ }^{1}$ George G. Higgins, "Remarks Upon Receipt of the Hubert Humphrey Civil Rights Award" (address for the Leadership Conference on Civil Rights, Washington, D.C., January 22, 1979), ACUA/GGH Papers, Box 334, Folder $1,2$.
} 
source in society for the protection of the laborer's rights and the improvement of his condition. No amount of employer benevolence, no diffusion of a sympathetic attitude on the part of the public, no increase of beneficial legislation, can adequately supply for the lack of organization among the workers themselves. ${ }^{2}$

Consequently, the passage of the NLRA represented one of the great accomplishments of the $20^{\text {th }}$ century in the eyes of the SAD, and was seen as the standard by which all future legislation would be judged. Unfortunately, within three years of Higgins's arrival at the department, the passage of the Taft-Hartley Act in 1947 threatened to undermine much of what the NLRA had accomplished. Ryan had always believed that legislation and the power of the state were the best means to change the social order, but in this instance, government and legislation had set back the department's goal of social change. First and foremost, it prohibited the closed shop, which allowed employers to require their workers to be union members, even before hiring. Secondly, it enabled the states to pass legislation that would prohibit the union shop as well. To make matters worse, Taft-Hartley remained a constant thorn in the side of the SAD, as all efforts to repeal it failed. As a consequence, Higgins and his fellow staff members learned a valuable lesson. Neither legislation nor government intervention was a panacea for the social ills of the country, despite what Ryan believed as director of the department.

Higgins understood that Taft-Hartley was unlikely to be repealed during his years at the department, or at the very least, that the department could not count upon its repeal during that time. Through its provisions against the closed shop, and its enabling of the states to pursue the prohibition of the union shop, Higgins argued that Taft-Hartley had effectively prevented one of the main intents of the NLRA, which was to promote the organization of all workers in American industry, even if that meant through compulsory means. From Higgins's view, there

\footnotetext{
${ }^{2}$ Ibid.
} 
was nothing wrong with such intent, as it fell in line with Catholic social teaching. Man was much more than just an individual in the eyes of the Church - man was also a member of society. As a member of society, the individual also had responsibilities to promote its well-being. Higgins argued that as members "of civil society," humanity had to "obey laws, pay taxes and fulfill our duties as citizens." The call for compulsory union membership was similar in this regard, in that "the common good of industrial society may demand that individuals conform to rules laid down for the good of all."3 It was for this reason that Higgins believed compulsory unionism was an acceptable limitation on human freedom, since it benefited the common good. As a consequence, he argued that the

principle behind such conditions is that the common good of the professional or plant community must prevail.... If an employer and a union agree in collective bargaining that union security would aid industrial relationships, they are in effect laying down a regulation for the common good of their industrial community. When a worker accepts employment in that plant, he is no longer a detached, isolated individual. He is a member of the community and is governed by its rules. The alternative to such a procedure would be anarchy and the breakdown of industrial society. ${ }^{4}$

Unfortunately, Taft-Hartley prevented such a practice. As a consequence, Higgins and the SAD had to pursue other avenues to accomplish the same ends that the NLRA had originally intended.

Fortunately for Higgins, the SAD found a ready solution in the Industry Council Plan advocated by Pius XI's encyclical of 1931, Quadragesimo Anno. Pius XI's plan rested squarely upon the principle of subsidiarity, which the advocated the rights of both individuals and associations to accomplish what they may through their own initiative and industry, while at the same time calling for the collaboration of these associations with the government in order to

\footnotetext{
${ }^{3}$ George G. Higgins, "Address for the $24^{\text {th }}$ Annual Convention of the Louisiana AFL-CIO" (address for the Louisiana AFL-CIO, March 20, 1979), ACUA/GGH Papers, Box 334, Folder 2, 6.

${ }^{4}$ Ibid.
} 
promote the common good of all. In this sense it also declared it an "injustice and at the same time a grave evil and disturbance of right order to assign to a greater and higher association what lesser and subordinate organizations can do." ${ }^{5}$ And while the principle of subsidiarity maintained that the government had a role to play alongside voluntary associations in the management of the social order, it was clear to those of the SAD that it had betrayed this principle by passing the Taft-Hartley Act.

The restriction of the organizational methods of the labor movement was a serious problem for Higgins and the SAD. In order to achieve the task outlined by Quadragesimo Anno, Higgins and the staff of the SAD recognized that the organization of the workers had to occur first. If not, its federation of voluntary associations would never come to pass. Unfortunately, Taft-Hartley obstructed both Higgins and the labor movement in this vital task. Complicating matters, at the same time Higgins became director of the Department, the fruits of Taft-Hartley were starting to ripen. Corruption had spread throughout the movement, which Higgins understood to be a symptom of the apathy of its rank-and-file. As he saw it, the apathy of the rank-and-file was a spiritual malaise that threatened the movement as a whole, and whose remedy could only be found in a return to its spiritual roots. As a consequence, Higgins developed and promoted Virgil Michel's liturgical theology as a means to return the labor movement to its spiritual principles. He believed that by doing so, the labor movement would not only be the better for it, but that it could accomplish the same ends that the NLRA had originally intended - the comprehensive organization of the workforce. In turn, this would enable the Industry Council Plan of Quadragesimo Anno to become a reality.

\footnotetext{
${ }^{5}$ Pius XI, Quadragesimo Anno, May 15, 1931, quoted in George G. Higgins, The Yardstick, "The Industry Council Program," November 18, 1946, ACUA/GGH Papers, Box 343, Folder 12.
} 
It is at this point that Higgins's unique contribution to the cause of Catholic social action starts to become clear. Realizing that Catholics made up a large portion of the working class, Higgins hoped to enlighten lay Catholics and motivate them to join and participate in their local union. He believed the Church had failed the laity in this regard, that it had put "the cart before the horse" in its presentation of lay social action, and that that it had "been appealing to the laity to engage in Catholic social action without first telling them, theologically, why they ought to do

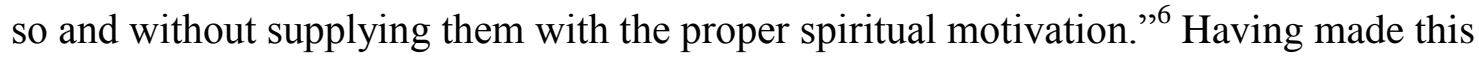
realization, Higgins sought to do just that - to spiritually motivate the Catholic laity, who made up the majority of the rank-and-file. He promoted the liturgical movement as the means to motivate them, arguing that it was only with Christ that "the labor movement can go forward to create a culture which will be truly representative of man's essential dignity and worth." Otherwise, he believed that it would "inevitably go the way of all flesh and ... betray the cause of social justice to which it is dedicated."7 Consequently, what Higgins proposed was the integration of the individual Catholic's secular and spiritual life, and in such a way that they might fulfill their religious obligations by Christianizing their secular workplaces.

In fairness, it should be mentioned that John A. Ryan never had the opportunity to address the Taft-Hartley Act, having passed away some 2 years before its passage. However, it is highly unlikely that he would have followed such a course, as he was largely unaware of the liturgical movement. ${ }^{8}$ Given Higgins's training under Reynold Hillenbrand, he was well versed in Virgil Michel's liturgical theology, which enabled him to propose a unique way to solve the

\footnotetext{
${ }^{6}$ George G. Higgins, "The Laity and Social Action,” The Yardstick, Dec. 24, 1956, ACUA/GGH Papers, Box 345, Folder 16.

${ }^{7}$ George G. Higgins, address presented at the Communion Breakfast, Saint Patrick's Cathedral Parish, Norwich, Connecticut, March 10, 1957, ACUA/GGH Papers, Box 324, Folder 12, 3.

${ }^{8}$ Francis L. Broderick, Right Reverend New Dealer: John A. Ryan (New York: The Macmillan Company, 1963), 242.
} 
complications that Taft-Hartley had created. Through his promotion of the liturgical movement Higgins believed the organization of the working class would occur without the need for compulsory measures. Instead, the rank-and-file would both join and participate in the labor movement as a natural expression of their religious identity.

And while the introduction of Virgil Michel's liturgical theology was important to the labor movement and its efforts to combat Taft-Hartley, its introduction was a significant development for Catholic social action within the United States as well. Prior to both Higgins's and Michel's efforts, the majority of Catholics approached Catholic Action in the same way that Pius XI had defined it in his encyclical, Non Abbiamo Bisogno. Published on June 29, 1931, the pontiff's encyclical emphasized the role of the laity in the Church's effort to change the social order, which had been expressed some six weeks prior in his encyclical Quadragesimo Anno. However, while the role of the laity was encouraged in this regard, Pius XI stipulated that such efforts had to take place in approved Catholic organizations under the direction of the hierarchy. Higgins's efforts to encourage lay Catholics to Christianize the work place challenged this traditional understanding of Catholic Action, for he argued that lay Catholics could change the social order without the direct supervision of the hierarchy. From Higgins's vantage, the laity shared in the apostolate of the Church as members of the Mystical Body of Christ. As a consequence, lay members of the Church held their own competence in social matters apart from that of the hierarchy.

In a similar circumstance to that of Ryan, Higgins believed his approach to the lay apostolate had been justified by Pope John XXIII's Mater et Magistra and Pacem in Terris, just as Ryan's views of social reconstruction had been validated by Pope Pius XI's Quadragesimo Anno. Higgins noted that Mater et Magistra had declared that no man should "imagine a life of 
activity in the world [that] is incompatible with spiritual perfection," and that it was a "gross error to suppose that a man cannot perfect himself except by putting aside all temporal activity, on the plea that such activity will inevitably lead him to compromise his personal dignity as a human being and as a Christian." ${ }^{99}$ To Higgins, it was clear that the pontiff supported the synthesis of the lay Catholics' spiritual and secular lives in order to bring about social change. Similarly, he believed Pacem in Terris made it clear that Catholics had to engage the world alongside non-Catholics towards this pursuit of the common good. It stated that every human being was endowed with "intelligence and free will," and that every man had the right to "worship God in accordance with the right dictates of his own conscience, and to profess his religion both in private and in public." According to Higgins, this validated his belief that unions were an acceptable medium to bring about this social change, especially given that their foundation rested on religious principles. Consequently, Higgins redoubled his efforts towards the development of such a lay apostolate, even arguing that Catholics had to expand their horizons of social justice beyond those that Catholic organizations offered.

This understanding of the lay apostolate and its role within American society was officially validated by two of the Second Vatican Council's decrees, Gaudium et Spes, the Pastoral Constitution of the Church in the Modern World, and Lumen Gentium, the Dogmatic Constitution of the Church. The two decrees, when viewed in conjunction with one another, presented all members of the Church as the Mystical Body of Christ, and asserted that all of its members shared in its apostolic mission. As apostles in their own right, the laity no longer had to view their apostolate as an extension of that of the hierarchy's. Instead, the laity could view their

\footnotetext{
${ }^{9}$ Pope John XXIII, "Mater et Magistra: Encyclical of Pope John XXIII On Christianity and Social Progress," The Holy See, http://www.vatican.va/holy_father/john_xxiii/encyclicals/documents/hf_jxxiii_enc 15051961_mater_en.html (accessed 11.13.2013).
} 
apostolate as a sharing in the mission of the entire Church. In this capacity the lay members of the Church held a unique competence in the social apostolate's application within the secular world. While the clergy and the hierarchy were present to teach and guide them, it was ultimately the laity's place to engage the world through their secular - yet spiritual - lives. As a part of this engagement with the world, dialogue was paramount, especially with those who weren't Catholic. The Church had realized that it did not have all the solutions to the problems of the modern world, but acknowledged that if solutions were to be found, they had to be discovered in conversation with "all men of good will." The apostolate of the laity was essential to this task.

For Higgins, Gaudium et Spes served as a validation for his promotion of Virgil Michel's liturgical theology, and his own advocacy of American secular unions as the best means to change the social order for the better. As a consequence, the intent of the NLRA to encourage the organization of all workers remained paramount for Higgins and for the American Church. Fortunately, Gaudium et Spes reaffirmed the rights of the individual to join unions, asserting that among the

basic rights of the human person must be counted the right of freely founding labor unions. These unions should be truly able to represent the workers and to contribute to the proper arrangement of economic life. Another such right is that of taking part freely in the activity of these unions without risk of reprisal. Through this sort of orderly participation, joined with an ongoing formation in economic and social matters, all will grow day by day in the awareness of their own function and responsibility. Thus they will be brought to feel that according to their own proper capacities and aptitudes they are associates in the whole task of economic and social development and in the attainment of the universal common good. ${ }^{10}$

\footnotetext{
${ }^{10}$ George G. Higgins, "Address for the $13^{\text {th }}$ Annual Convention of the Industrial Union Department, AFL-CIO" (address, San Francisco, CA, September 19, 1979), ACUA/GGH Papers, Box 334, Folder 6, 3.
} 
Unfortunately, not all Catholics had heeded the call issued by Gaudium et Spes, particularly the Catholic growers of Delano and Salinas, California. Consequently, Higgins found himself once again fighting for the rights of the workers soon after the close of the Council.

In a twist of historical irony, the fact that agricultural workers were not covered by the NLRA allowed Cesar Chavez and his union, the United Farm Workers of America, to effectively fight for the right to organize and bargain collectively against the growers of California. By their exclusion from the Act, Cesar and the UFW were able to conduct boycotts against the growers, which effectively forced them to the bargaining table. The battle between the two groups was uniquely Catholic, as Chavez had incorporated the social teachings of the Church, as well as liturgical elements of the Catholic Mass, into his effort to organize farm laborers, who mainly identified themselves as Catholics. At the same time, the growers were largely Catholic as well, and as families of means, had contributed extensively to the dioceses there. Given the Catholic background of both the farmworkers and the growers of California, the conflict between the two placed the American Church in a unique position to apply the principles of its social encyclicals, as well as its decrees from the Second Vatican Council, to the problem at hand. In response, the American bishops formed the Bishops' Ad Hoc Committee on Farm Labor, and Higgins was appointed as one of its members. As a member of this Committee, Higgins hoped to mediate the conflict, and encourage the growers to acknowledge the farm workers' right to organize and bargain collectively. These rights were non-negotiable as far as he was concerned, since they represented Catholic teaching. Ultimately, by mediating the conflict, Higgins helped forge legislation that accomplished what the NLRA did not - the organization of farm workers in California. 
All of these events and circumstances sum up in large part the life of a man dedicated to the common good. As a "labor priest," George Higgins had consistently fought for his fellow men and their right to assert themselves as members of a larger community, whether this was at their local factory, within their union, in relation to their government, or even within their Church. In this sense, the principle of subsidiarity served as the compass for both his life and his view of the world. By advocating this principle, Higgins helped guide the American Church in its efforts to bring about a new social order. It was a balanced social order, one where the lay people of the Church were expected to engage the secular world in a spiritual way. By doing so, he promoted a new understanding of the role of the laity within the Catholic Church, where they served as experts in secular matters, since they were the ones who engaged the world through their everyday lives. Consequently, one might argue that Higgins empowered lay Catholics by applying the principle of subsidiarity in relation to the Church itself. Rather than be directed by the hierarchy, the laity was expected to cooperate with them of their own initiative. This was expected of them as members of the Mystical Body who shared in the common apostolate of the Church. As members of this body, the secular world was their domain, and through their own associations they would change it for the betterment of all.

In the larger context of American Catholic history, Higgins's time at the SAD depicts an American Church in reaction to a government that had passed the Taft-Hartley Act. For the American Catholic Church, this was a betrayal of the first degree. Gone were the heydays of the New Deal, and the belief that government served as the solution to all social ills. Fortunately, through Higgins the Church was well prepared to adapt to this new environment, as he continually promoted the cooperation of industry, labor, and government as the best means to solve the social problems of his day. And while the Industry Council Plan never came to 
fruition, this did not mean that the efforts of Higgins and the SAD were a failure. Through his determination, Higgins helped labor overcome its reluctance to trust and participate with the government in the management of its affairs, as evidenced by both his support of the movement and his actions during the McClellan Committee crisis. More so, Higgins had developed and promoted the means for the unions' rank-and-file to overcome the apathy that Taft-Hartley had created. Consequently, it was with confidence that in the year preceding his retirement he could assert that there was "no other movement in sight which would enable the American workers to protect their legitimate economic interests and at the same time play an effective and responsible role, under a system of industrial democracy, in helping to promote the general economic welfare." 11 He could do so because he believed he had left the movement in capable hands - the hands of those who had united their secular and spiritual lives. For Higgins, the movement remained as he had always envisioned it, a movement based on spiritual and religious principles.

\footnotetext{
${ }^{11}$ Ibid., 5 .
} 


\section{Bibliography}

\section{Manuscript Collections}

Association of Chicago Priests Records. University of Notre Dame Archives, University of Notre Dame, South Bend, IN.

Catholic Committee on Urban Ministry. Papers. University of Notre Dame Archives, University of Notre Dame, South Bend, IN.

Higgins, George G., Papers. Catholic University of America Archives, Catholic University of America, Washington, DC.

United States Conference of Catholic Bishops: Office of the General Secretary. Papers. Catholic University of America Archives, Catholic University of America, Washington, DC.

United States Conference of Catholic Bishops: Social Action Department. Papers. Catholic University of America Archives, Catholic University of America, Washington, DC.

\section{Published Primary Sources}

AFL-CIO, AFL-CIO Codes of Ethical Practices. Washington, D.C.: AFL-CIO, 1958.

Buckley, Jr., William F. "For the Record.” The National Review, August 12, 1961. . "The Week." The National Review, July 29, 1961.

Commonweal. "Getting the Ax." October, 27, 1978.

Costello, Gerald M. Without Fear or Favor: George Higgins on the Record. Mystic: TwentyThird Publications, 1984.

Davis, Thurston N. "Magistra, Si.” America, September 30, 1961. . "William F. Buckley Jr.” America, August 19, 1961.

Ellis, John Tracy. Documents of American Catholic History. Milwaukee: The Bruce Publishing Company, 1956.

Inc., 1987.

. Documents of American Catholic History. Volume 2. Wilmington: Michael Glazier 
Guilday, Peter. The National Pastorals of the American Hierarchy (1792 - 1919). Washington, D.C.: National Catholic Welfare Council, 1923.

Higgins, George G. "Voluntarism in Organized Labor in the United States, 1930 - 1940." PhD diss., Catholic University of America, 1944.

Higgins, George G., and William Bole. Organized Labor and the Church: Reflections of a “Labor Priest”. New York: Paulist Press, 1993.

Huber, Raphael M. Our Bishops Speak: National Pastorals and Annual Statements of the Hierarchy of the United States. Milwaukee: The Bruce Publishing Company, 1952.

Pope John XXIII. "Mater et Magistra: Encyclical of Pope John XXIII on Christianity and Social Progress." The Vatican.

http://www.vatican.va/holy_father/john_xxiii/encyclicals/documents/hf_jxxiii_enc_15051961_mater_en.html (accessed 10.14.13).

. "Pacem in Terris: Encyclical of Pope John XXIII on Establishing Universal Peace in Truth, Justice, Charity, and Liberty." The Vatican. http://www.vatican.va/holy_father/john_xxiii/encyclicals/documents/hf_jxxiii_enc_11041963_pacem_en.html (accessed 10.14.13).

Pope Leo XIII. "Rerum Novarum: Encyclical of Pope Leo XIII on Capital and Labor." The Vatican. http://www.vatican.va/holy_father/leo_xiii/encyclicals/documents/hf_lxiii_enc_15051891_rerum-novarum_en.html (accessed 10.14.13).

Pope Pius XI. “Quadragesimo Anno: Encyclical of Pope Pius XI on Reconstruction of the Social Order.” The Vatican. http://www.vatican.va/holy_father/pius_xi/encyclicals/documents/hf_pxi_enc_19310515_quadragesimo-anno_en.html (accessed 10.14.13).

. "Divini Redemptoris: Encyclical of Pope Pius XI On Atheistic Communism," The Vatican. http://www.vatican.va/holy_father/pius_xi/encyclicals/documents/hf_pxi_enc_19031937_divini-redemptoris_en.html (accessed 10.15.13)

Ryan, John A. “The Bishops' Program of Social Reconstruction.” The American Catholic Sociological Review 5 (March, 1944): 25 - 33 . A Living Wage: Its Ethical and Economic Aspects. New York: Macmillan Press, 1908. . Social Doctrine in Action: A Personal History. New York: Harper \& Brothers Publishers, 1941. 
Skillin, Edward S. "Week by Week: The New Encyclical.” Commonweal, July 28, 1961.

The United States Conference of Catholic Bisops. "Guidelines for Catholic-Jewish Relations. (1967).” http://www.usccb.org/seia/guidelines_catholic-jewish.pdf (accessed 10.14.13).

The Vatican. "Decree on the Apostolate of the Laity: Apostolicam Actuositatem." http://www.vatican.va/archive/hist_councils/ii_vatican_council/documents/vatii_decree_19651118_apostolicam-actuositatem_en.html (accessed 10.14.13).

The Vatican. "Guidelines and Suggestions for Implementing the Conciliar Declaration 'Nostra Aetate.' (n.4).” http://www.vatican.va/roman_curia/pontifical_councils/chrstuni/relations-jewsdocs/rc_pc_chrstuni_doc_19741201_nostra-aetate_en.html (accessed 10.14.13).

The Vatican. "Declaration on the Relation of the Church to Non-Christian Religions: Nostra Aetate." http://www.vatican.va/archive/hist_councils/ii_vatican_council/documents/vatii_decl_19651028_nostra-aetate_en.html (accessed 10.14.13).

The Vatican. "Pastoral Constitution on the Church in the Modern World: Gaudium Et Spes." http://www.vatican.va/archive/hist_councils/ii_vatican_council/documents/vatii_cons_19651207_gaudium-et-spes_en.html (accessed 10.14.13).

\section{Secondary Sources}

Abell, Aaron I. American Catholicism and Social Action: A Search for Social Justice, 1865 1950. Notre Dame: University of Notre Dame Press, 1960.

Alberigo, Guiseppe and Joseph A Komonchak. History of Vatican II: Volumes 1 -5. Maryknoll: Orbis Books, 1995.

Avella, Steven M. "Reynold Hillenbrand and Chicago Catholicism." U.S. Catholic Historian 1990 9(4): 353-370.

. "Chicago's Sons: George G. Higgins and Reynold Hillenbrand." U.S. Catholic

Historian 19, no. 4 (Fall 2001): 25 - 32.

Batdorf, Sylvia M. "The Work of the Social Action Department of the National Catholic Welfare Conference in all Phases of Industrial Relations." Master's Thesis, Catholic University of America, 1933.

Betten, Neil. Catholic Activism and the Industrial Worker. Gainesville: University Presses of Florida, 1976.

Bimba, Anthony. The Molly Maguires. New York: International Publishers, 1932. 
Broderick, Francis L. Right Reverend New Dealer. New York: The Macmillan Company, 1963.

Broehl, Jr., Wayne G. The Molly Maguires. Cambridge: Harvard University Press, 1965.

Browne, Henry J. The Catholic Church and The Knights of Labor. New York: Arno Press, 1976.

Bruns, Roger. Cesar Chavez: A Biography. Westport: Greenwood Press, 2005.

Calvez, Jean-Yves. The Social Thought of John XXIII: Mater et Magistra. Translated by George J.M. McKenzie, Chicago: S.M. Henry Regnery Company, 1964.

Chinnici, Joseph P. Living Stones: The History and Structure of Catholic Spiritual Life in the United States. Maryknoll: Orbis Books, 1996.

Costello, Gerald M. “The Farm Labor Movement.” U.S. Catholic Historian 19, no. 4 (Fall 2001): $33-40$.

Curran, Robert E. Michael Augustine Corrigan and the Shaping of Conservative Catholicism in America, 1878 - 1902. New York: Arno Press, 1978.

Dolan, Jay P. The American Catholic Experience: A History from Colonial Times to the Present. Garden City: Doubleday \& Company, 1985.

Dolan, Timothy M. “The Bishops in Council.” First Things 152 (April 2005): 20 - 25.

Dulles, Foster R. and Melvyn Dubofsky, Labor in America: A History. $4^{\text {th }}$ ed. Arlington Heights: Harlan Davidson, Inc., 1984

Editorial Staff of the Bureau of National Affairs, The McClellan Committee Hearings - 1957. Washington, D.C.: Bureau of National Affairs, 1958

Edmonson, Elizabeth A. "Without Comment or Controversy: The G.I. Bill and Catholic Colleges." Church History 71, no. 4 (Dec. 2002): 820 - 847.

Ferriss, Susan, and Ricardo Sandoval. The Fight in the Fields: Cesar Chavez and the Farmworkers Movement. New York: Harcourt Brace \& Company, 1997.

Flanagan, Sean B. "Catholic Social Principles and Chavez: A Case Study.” Master's Thesis, Loyola University of Los Angeles, 1971.

Fogarty, Gerald P. The Vatican and the American Hierarchy from 1870 to 1965. Collegeville: The Liturgical Press, 1982.

Franklin, R.W., and Robert L. Spaeth. Virgil Michel: American Catholic. Collegeville: The Liturgical Press, 1988. 
Garcia, Matt. From the Jaws of Victory: The Triumph and Tragedy of Cesar Chavez and the Farm Worker Movement. Berkeley: University of California Press, 2012.

Gleason, Philip. The Conservative Reformers: German-American Catholics and the Social Order. Notre Dame: University of Notre Dame Press, 1968.

Godfried, Nathan. WCFL: Chicago's Voice of Labor, 1926 - 1978. Urbana: University of Illinois Press, 1997.

Goldberg, Arthur J. AFL-CIO: Labor United. New York: McGraw Hill Book Co., 1956.

Greene, Thomas R. "The Catholic Conference on Industrial Problems in Normalcy and Depression." Catholic Historical Review 77, no. 3 (July 1991): 437-469.

Howe, Irving, and B.J. Widick. The UAW and Walter Reuther. New York: Random House, 1949.

Judis, John B. William F. Buckley, Jr.: Patron Saint of the Conservatives. New York: Simon \& Schuster, 1988.

Kennedy, Robert F. The Enemy Within. New York: Harper \& Brothers, 1960.

Koeth, Stephen M. "The Strength and Limits of American Catholic Confidence: Reverend John F. Cronin, S.S., and His Political Friendship with Richard M. Nixon, 1947 - 1960," Journal of Church and State, Advance Access Article, March 26, 2013 (online publication only)

Kohler, Thomas C. “Quadragesimo Anno.” In A Century of Catholic Social Thought: Essays on 'Rerum Novarum' and Nine Other Key Documents, edited by George Weigel and Robert Royal, 27 - 44. Washington, DC: Ethics and Public Policy Center, 1991.

Komonchak, Joseph A. "Subsidiarity in the Church: The State of the Question." The Jurist 48 (1988): $298-349$.

Lee, R. Alton. Truman and Taft-Hartley: A Question of Mandate. Lexington: University of Kentucky Press, 1966.

Lee, William James. "The Work in Industrial Relations of the Social Action Department of the National Catholic Welfare Conference, 1933 - 1945." Master's Thesis, Catholic University of America, 1946.

Levy, Jacques E. Cesar Chavez: Autobiography of La Causa. New York: W.W. Norton \& Company, Inc., 1975. 
Linkh, Richard M. American Catholicism and European Immigrants (1900 - 1924). New York: Center of Migration Studies, 1975.

Liptak, Dolores. Immigrants and Their Church. New York: Macmillan Publishing Company, 1989.

Majka, Linda C., and Theo Majka. Farm Workers, Agribusiness, and the State. Philadelphia: Temple University Press, 1982.

Marx, Paul B. Virgil Michel and the Liturgical Movement. Collegeville: The Liturgical Press, 1957.

Massa, Mark S. Catholics and American Culture: Fulton Sheen, Dorothy Day, and the Notre Dame Football Team. New York: Crossroad Publishing Company, 1999.

McKeown, Elizabeth K. "The National Bishops' Conference: An Analysis of Its Origins." Catholic Historical Review 1980 (66): 565-83.

McKillen, Elizabeth. Chicago Labor and the Quest for a Democratic Diplomacy, 1914 - 1924. Ithaca: Cornell University Press, 1995.

McShane, Joseph M. "Sufficiently Radical": Catholicism, Progressivism, and the Bishops' Program of 1919. Washington, D.C.: The Catholic University of America Press, 1986.

Miller, Raymond W. Monsignor Ligutti: The Pope's County Agent. Washington, D.C: University Press of America, 1981.

Minchin, Timothy J. "Don't Sleep with Stevens!'The J.P. Stevens Campaign and the Struggle to Organize the South, 1963 - 1980. Gainesville: University Press of Florida, 2005.

Mooney, Patrick H., and Theo J. Majka. Farmers' and Farm Workers' Movements: Social Protest in American Agriculture. New York: Twayne Publishers, 1995.

Murphy, William. "Rerum Novarum." In A Century of Catholic Social Thought: Essays on 'Rerum Novarum' and Nine Other Key Documents, edited by George Weigel and Robert Royal, 1 - 26. Washington, DC: Ethics and Public Policy Center, 1991.

Newell, Barbara Warne. Chicago and the Labor Movement: Metropolitan Unionism in the 1930's. Urbana: University of Illinois Press, 1961.

O'Brien, David. "American Catholics and Organized Labor in the 1930s." Catholic Historical Review 52, no. 3 (October 1966): 323-349. 
. American Catholics and Social Reform: The New Deal Years. New York: Oxford University Press, 1968.

. Public Catholicism. Maryknoll: Orbis Books, 1996.

O'Brien, David J., and Thomas A. Shannon, ed. Catholic Social Thought: The Documentary Heritage. Maryknoll: Orbis Books, 1992.

O'Brien, John J. George G. Higgins and the Quest for Worker Justice: The Evolution of Catholic Social Thought in America. Lanham: Rowman \& Littlefield Publishers, 2005.

. "George G. Higgins and the 'Yardstick' Columns." U.S. Catholic Historian 19, no. 4 (Fall 2001): $87-101$.

Olson, Keith W. The G.I. Bill, the Veterans, and the Colleges. Lexington: The University Press of Kentucky, 1974.

Orsi, Robert Anthony. The Madonna of $115^{\text {th }}$ Street: Faith and Community in Italian Harlem, 1880 - 1950. New Haven: Yale University Press, 1985.

Packard, Vance. The Status Seekers: An Exploration of Class Behavior in America and the Hidden Barriers That Affect You, Your Community, Your Future. New York: David McKay Co., 1959

Prentiss, Craig R. Debating God's Economy: Social Justice in America on the Eve of Vatican II. University Park: The Pennsylvania State University Press, 2007.

Prouty, Marco G. "Cesar Chavez and the Catholic Civil War, 1965 - 1977." PhD diss., The Catholic University of America, 2004.

. César Chávez, the Catholic Bishops, and the Farmworkers' Struggle for Social Justice. Tucson: The University of Arizona Press, 2008.

Reese, Thomas J., Editor. Episcopal Conferences: Historical, Canonical, and Theological Studies. Washington, D.C.: Georgetown University Press, 1989.

Robb, Dennis Michael. "Specialized Catholic Action in the United States, 1936 - 1949." PhD diss., University of Minnesota, 1972.

Rosswurm, Steve. "The Catholic Church and the Left-Led Unions: Labor Priests, Labor Schools, and the ACTU." In The CIO's Left-Led Unions, edited by Steve Rosswurm, 119 - 137. New Brunswick: Rutgers University Press, 1992. 
Rynne, Xavier. Vatican Council II. New York: Farrar, Straus and Giroux, 1968.

Sayles, Leonard R., and George Strauss. The Local Union: Its Place in the Industrial Plant. New York: Harper and Brothers, 1953.

Sheerin, John B. Never Look Back: The Career and Concerns of John J. Burke. New York: Paulist Press, 1975.

Sirico, Robert A. "Mater et Magistra." In A Century of Catholic Social Thought: Essays on 'Rerum Novarum' and Nine Other Key Documents, edited by George Weigel and Robert Royal, 45 - 59. Washington, DC: Ethics and Public Policy Center, 1991.

Slawson, Douglas J. The Foundation and First Decade of the National Catholic Welfare Council. Washington, DC: The Catholic University of America Press, 1992.

Stieber, Jack. Governing the UAW. New York: John Wiley and Sons, Inc., 1962.

Sullivan, Patrick J. Blue Collar - Roman Collar - White Collar: U.S. Catholic Involvement in Labor Management Controversies, 1960 - 1980. Lanham: University Press of America, 1987. . "George Higgins: The Labor Priests' Priest." U.S. Catholic Historian 19, no. 4 (Fall 2001): $103-118$.

Taft, Philip. Organized Labor in American History. New York: Harper \& Row, 1964.

Taylor, Ronald B. Chavez and the Farm Workers. Boston: Beacon Press, 1975.

Tuzik, Robert L. "The Contribution of Msgr. Reynold Hillenbrand (1905 - 1979) to the Liturgical Movement in the United States: Influence and Development." PhD diss., University of Notre Dame, 1989.

Wainwright, Geoffrey and Karen Westerfield Tucker. The Oxford History of Christian Worship. New York: Oxford University Press, 2006

Yzermans, Vincent A., Editor. American Participation in the Second Vatican Council. New York: Sheed and Ward, Inc., 1967. 